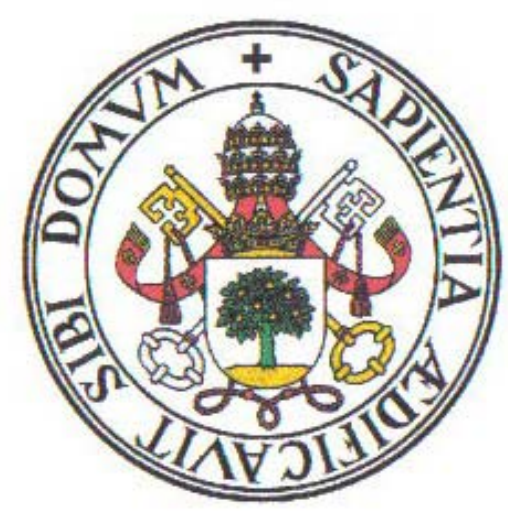

Universidad de Valladolid

FACULTAD DE MEDICINA

DEPARTAMENTO DE BIOQUIMICA Y BIOLOGIA MOLECULAR Y

FISIOLOGÍA

TESIS DOCTORAL:

\title{
DESARROLLO DE UNA MATRIZ TRIDIMENSIONAL PARA BIOINGENIERIA OSTEO-ARTICULAR
}

\footnotetext{
Presentada por VERÓNICA GARCÍA DÍAZ para optar al grado de doctora por la Universidad de Valladolid
}

\author{
Dirigida por: \\ Dra. Ana Sánchez García \\ Dr. Alvaro Meana Infiesta \\ Dr. Luis Miguel Redondo González
}

Valladolid, 2015 

La adquisición de los materiales y medios necesarios para las tareas de investigación desarrolladas en el trabajo presentado en esta tesis se ha realizado fundamentalmente con cargo a los fondos obtenidos de la ayuda FIS Intrasalud $n^{\circ}$ PI10/01566 titulada "Desarrollo de modelos tridimensionales de expansión celular para uso en Medicina Regenerativa", I.P. Dra. Ana Sánchez García y .la ayuda n EC10-255 del Ministerio de Sanidad y Política Social titulada "Ensayo clínico fase I/II para el estudio de la regeneración de defectos óseos maxilares por bioingeniería tisular con células mesenquimales autólogas y matriz de plasma", I.P. Dr. Luis Miguel Redondo. Este trabajo de investigación se ha podido desarrollar gracias a la financiación y a la colaboración aportada por las siguientes entidades:

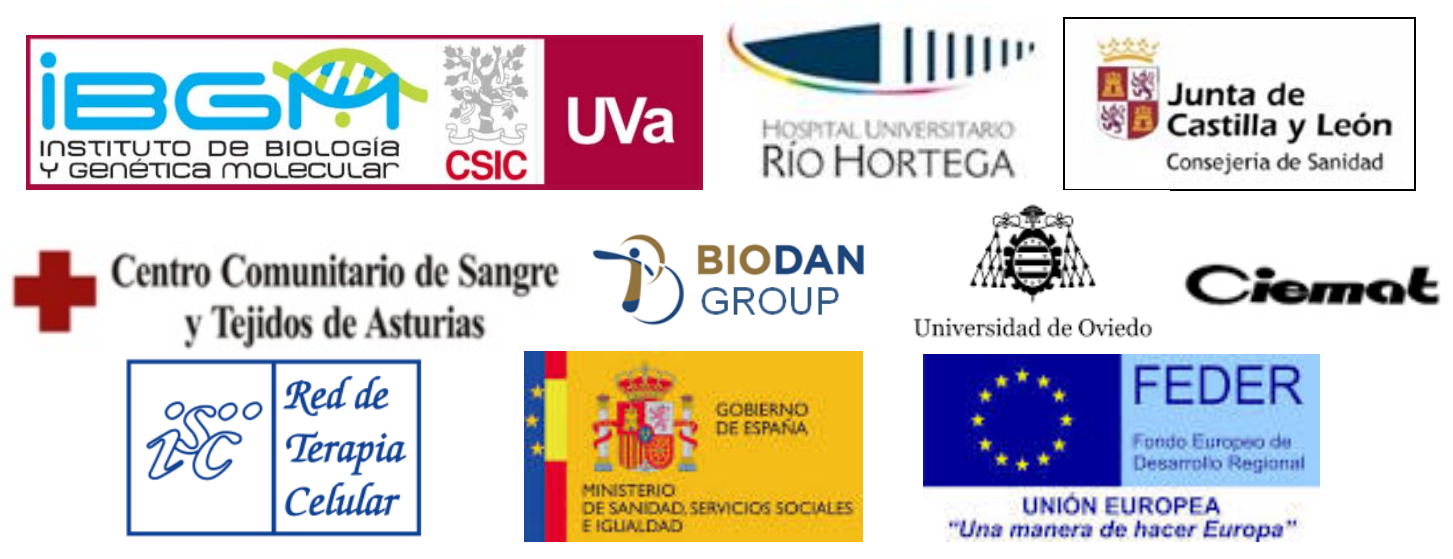





\section{AGRADECIMIENTOS}

Deseo expresar mi agradecimiento a todas las personas que de un modo $\mathrm{u}$ otro han colaborado en el desarrollo de este trabajo; sobre todo a los pacientes y donantes que sin su colaboración no habría sido posible la realización del mismo.

En primer lugar quiero agradecer a mis directores de tesis, a la Dra. Ana Sánchez García por confiar en mí y brindarme la oportunidad de estar aquí, al Dr. Álvaro Meana Infiesta, por introducirme en el campo de la investigación y apoyarme en todo momento y finalmente al Dr. Luis Miguel Redondo González y a todo su equipo por hacer posible todo el trabajo tanto con los animales como con el desarrollo del ensayo clínico.

Al Dr. Javier García-Sancho por su ayuda con todos los análisis y por su orientación y apoyo en todo momento.

A todas mis compañeras y compañeros de la UPC especialmente a Sandra Güemes, porque con nuestros más y nuestros menos siempre está ahí para apoyarme y guiarme en mis dudas; a. Virginia Gordillo, por su apoyo incondicional y por ofrecerme la ayuda necesaria en cada momento, a Mercedes Alberca por ayudarme y trasmitirme todo su conocimiento en citometría; a Africa Cubero por ayudar siempre con las dudas microbiológicas y a los técnicos Berta Santa Úrsula y Vicky Sáez por su trabajo con la histología.

Al personal del Banco de Tejidos del Centro Comunitario de Sangre y Tejidos del Principado de Asturias (C.C.S.T) por prestarme su ayuda en cualquier momento, en especial a mi antigua compañera Eva García Pérez, por estar siempre al otro lado y por su gran amistad.

A la Dra. Lorena Gallego López y a los doctores Gonzalo de la Peña y Javier Fernández Doval, por todo el desarrollo preclínico.

Finalmente, a toda mi familia, porque siempre me apoyan tanto los que están como los que no están. 

A mis padres y mi hermana

A Adrián

A mis pequeños príncipes 

ABREVIATURAS 



\begin{tabular}{|c|c|}
\hline AA & Acontecimiento adverso \\
\hline AAG & Acontecimiento adverso grave \\
\hline AEMPS & Agencia Española de Medicamentos y Productos Sanitarios \\
\hline bFGF & Factor de Crecimiento Fibroblástico básico \\
\hline BMPs & Proteínas Morfogenéticas Óseas \\
\hline BPC & Buena Práctica Clínica \\
\hline CCAA & Comunidades Autónomas \\
\hline CEIC & Comité Ético de Investigación Clínica \\
\hline CT3P & Count- Tact 3P Agar Irradiado \\
\hline CTSI & Count- Tact Sabouraud Dextrosa Cloramfenicol Irradiado \\
\hline DMEM & Medio Dulbecco's Modified Eagle's \\
\hline DMSO & Dimetil-sulfóxido \\
\hline DS & Desviación estandar \\
\hline EC & Ensayo Clínico \\
\hline EDTA & Ácido etilendiaminotetraacético \\
\hline ESC & Células madre embrionarias \\
\hline FA & Fosfatasa Alcalina \\
\hline FDA & $\begin{array}{l}\text { Administración de medicamentos y alimentos } \\
\text { (Food and Drugs Administration) }\end{array}$ \\
\hline GMP & Buena Práctica de Fabricación (Good Manufacturing Practise) \\
\hline HA & Hidroxiapatita \\
\hline H/E & Hematoxilina/Eosina \\
\hline HEPES & 4-(2-hydroxyethyl)-1-piperazineethanesulfonic acid \\
\hline HPL & Lisado plaquetario humano \\
\hline HS & Suero humano \\
\hline HURH & Hospital Universitario Rio Hortega \\
\hline IBGM & Instituto de Biología y Genética Molecular deValladolid \\
\hline $\mathrm{ICH}$ & International Conference on Harmonization \\
\hline IGF & Factor análogo a la Insulina \\
\hline IND & Nuevas drogas en investigación (Investigational New Drug) \\
\hline iPS & Células madre pluripotentes inducidas (Induced Pluripotent Stem) \\
\hline LIF & Factor Inhibidor de la Leucemia \\
\hline LQM & Lesión quística maxilar \\
\hline MSC & Células Mesenquimales \\
\hline MSV-H & Células Mesenquimales de hueso \\
\hline NMR & Resonancia magnética nuclear \\
\hline
\end{tabular}




$\begin{array}{ll}\text { NCF } & \text { Normas de Correcta Fabricación } \\ \text { P/E } & \text { Penicilina/Estreptomicina } \\ \text { PBS } & \text { Tampón fosfato salino (Phosphated buffered saline) } \\ \text { PCR } & \text { Reacción en cadena de la polimerasa } \\ \text { PDGF } & \text { Factor de crecimiento derivado de las plaquetas } \\ \text { PEI } & \text { Producto en fase de Investigación } \\ \text { PGA } & \text { Ácido poliglicólico } \\ \text { PLA } & \text { Ácido poliláctico } \\ \text { PLDL } & \text { Poli (L-láctico-co-D, L-láctico) } \\ \text { PNTs } & \text { Procedimientos normalizados de trabajo } \\ \text { PRP } & \text { Plasma rico en plaquetas } \\ \text { RER } & \text { Retículo Endoplasmático Rugoso } \\ \text { RGD } & \text { Tripéptido Arginina-Glicina-Aspartato } \\ \text { ROI } & \text { Región de interés “Region of interest" } \\ \text { rPm } & \text { Revoluciones por minuto } \\ \text { RPMI 1640 } & \text { Roswell Park Memorial Institute 1640 } \\ \text { SDCI } & \text { Sabouraud dextroxa cloranfenicol irradiado } \\ \text { SBF } & \text { Suero bovino fetal } \\ \text { T/E } & \text { Tripsina/EDTA } \\ \text { TC } & \text { Tomografía Computerizada } \\ \text { TCP } & \text { Fosfato tricálcico } \\ \text { TGF- } \beta & \text { Factor transformante del crecimiento } \beta \\ \text { THIO } & \text { Caldo Tioglicolato } \\ \text { TSA } & \text { Trypcase soja agar irradiado } \\ \text { TSB-T } & \text { Caldo de Trypcase soja } \\ \text { UPC } & \text { Unidad de Producción Celular } \\ \text { VEGF } & \text { Factor de crecimiento endotelio vascular } \\ \text { VIH } & \text { Virus inmunodeficiencia humana } \\ & \end{array}$


ÍNDICE 



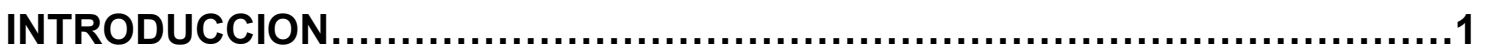

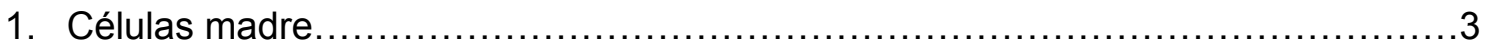

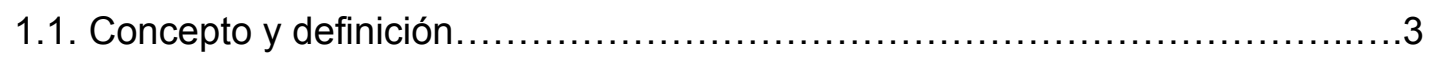

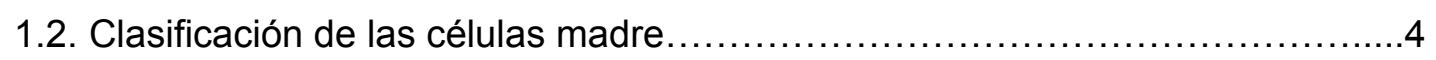

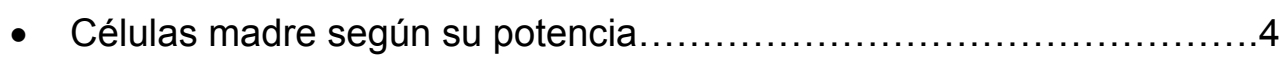

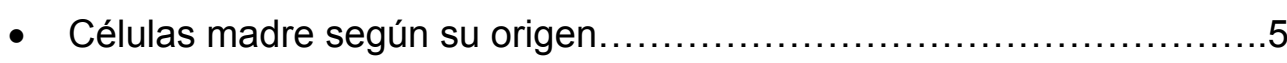

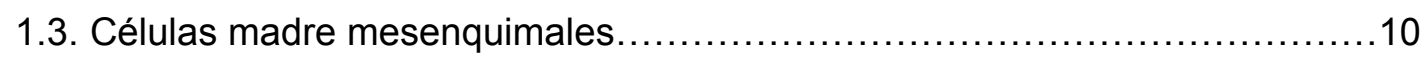

- Concepto y definición............................................10

- Terapia Celular con células madre mesenquimales...................12

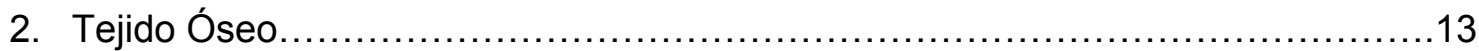

2.1. Concepto y definición.....................................................

2.2. Estructura del Tejido Óseo.............................................14

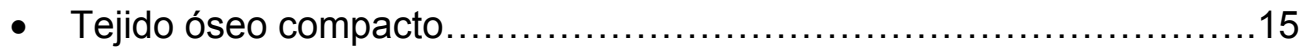

- Tejido óseo esponjoso o laminar.....................................16

2.3. Células del tejido óseo........................................................

- Células osteogénicas............................................16

• Osteoblastos.........................................................

• Osteocitos............................................................

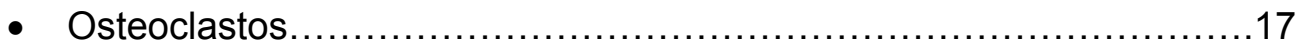

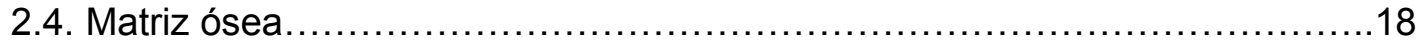

2.5. Formación del hueso .......................................................

- Osificación intramembranosa.......................................19

- Osificación endocondral............................................20

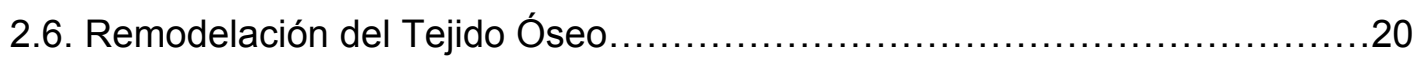

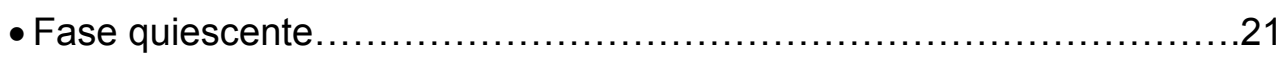

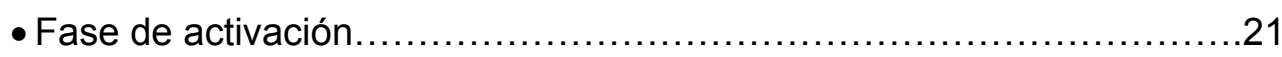

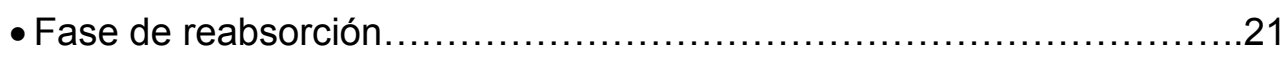

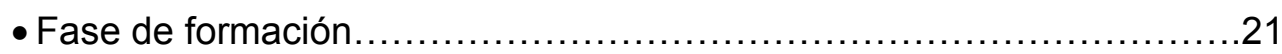

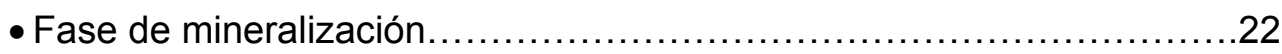

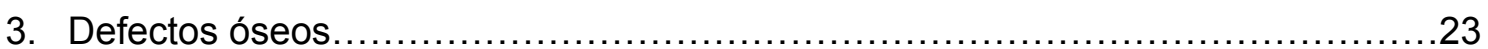




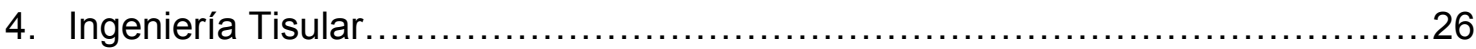

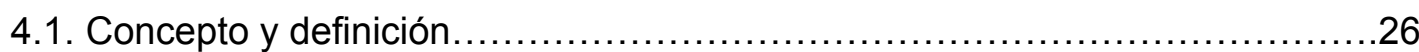

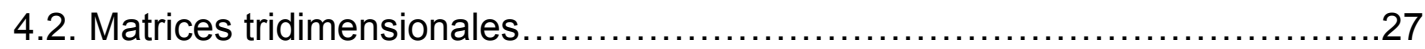

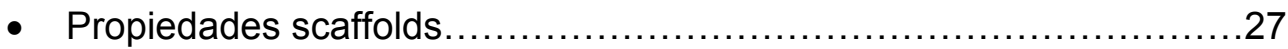

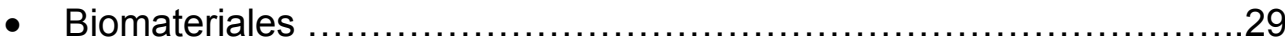

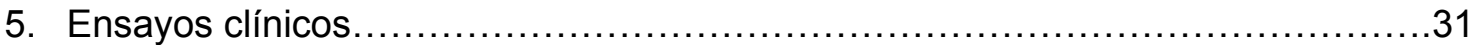

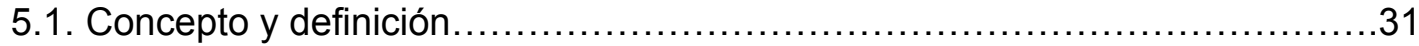

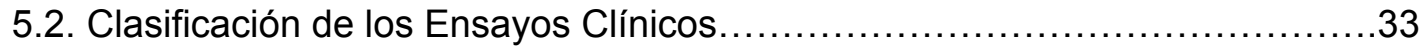

5.3. Principales Agentes en un Ensayo Clínico................................. 35

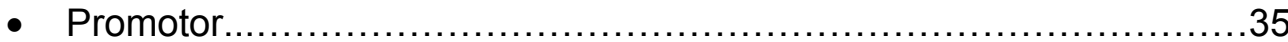

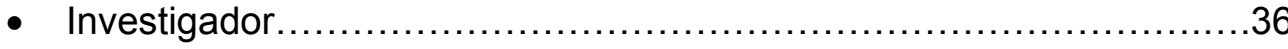

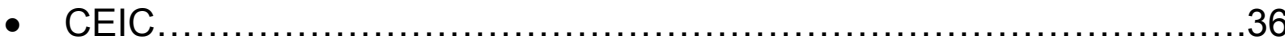

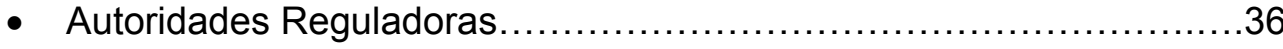

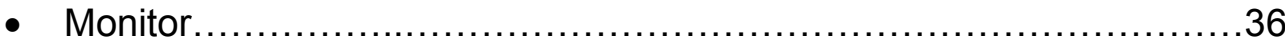

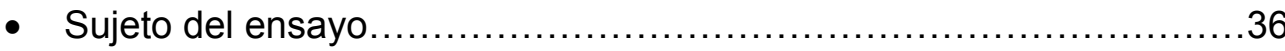

5.4. Etapas del Ensayo Clínico .............................................. 37

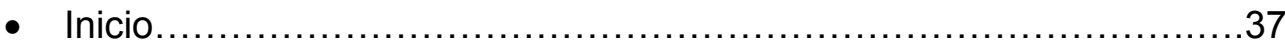

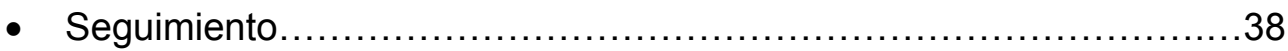

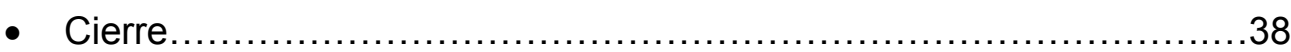

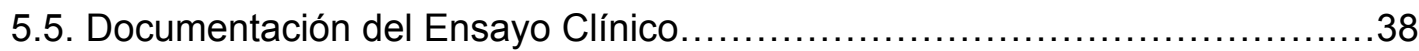

- Antes de comenzar la fase clínica del ensayo..........................38

- Durante el desarrollo del ensayo.....................................40

- Después de finalizar el ensayo...........................................41

HIPÓTESIS Y OBJETIVOS....................................................42

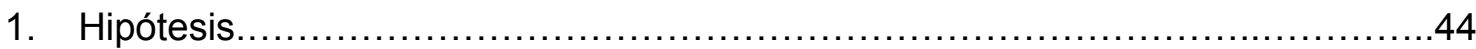

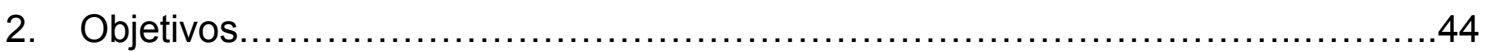

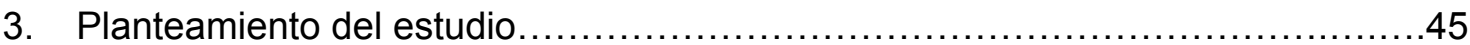

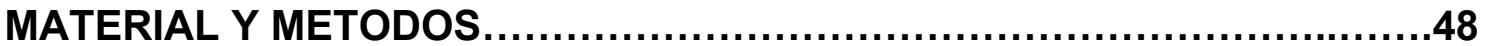

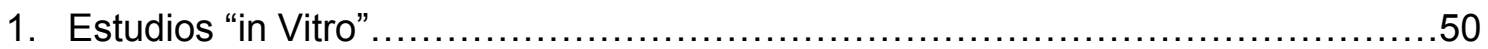

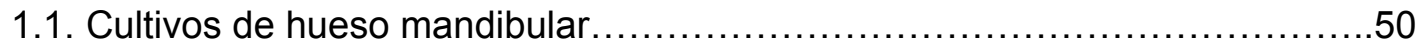

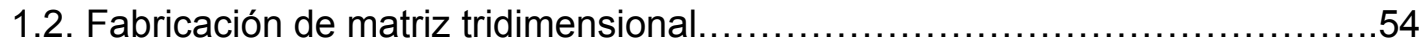

1.3. Cultivo del bioimplante (matriz + células) ..................................55 


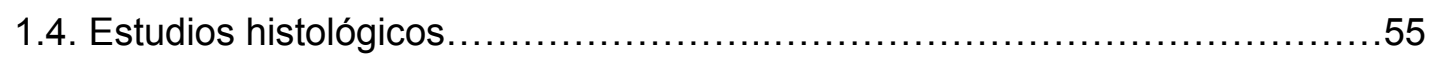

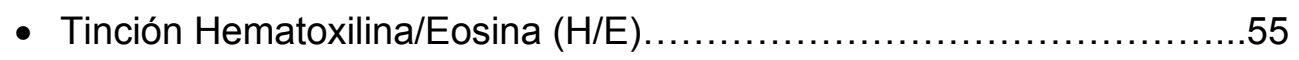

- Tinción de Von Kossa................................................56

1.5. Estudios microscopía electrónica de barrido............................56

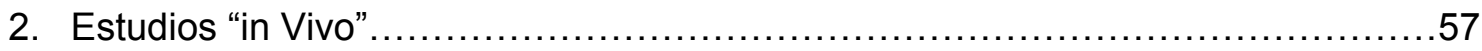

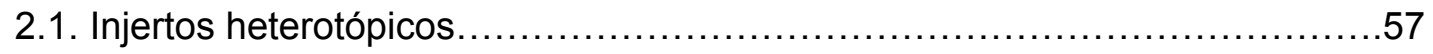

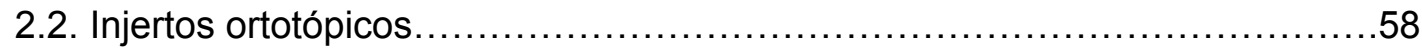

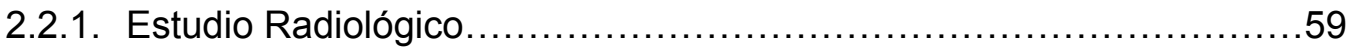

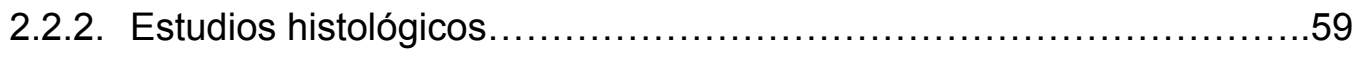

- Estudio de Vimentina humana.....................................59

- Estudio de Osteocalcina humana ....................................60

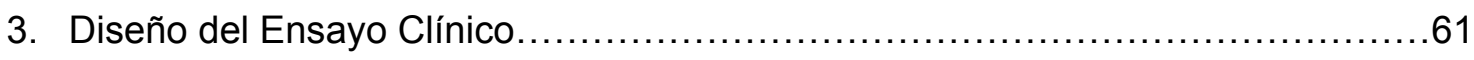

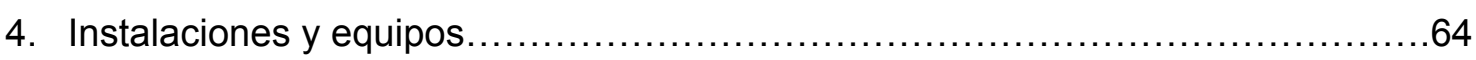

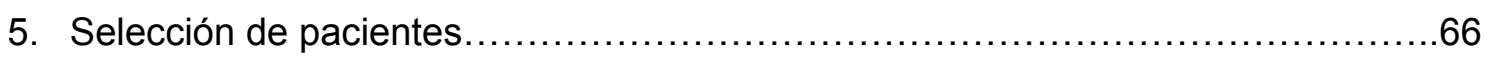

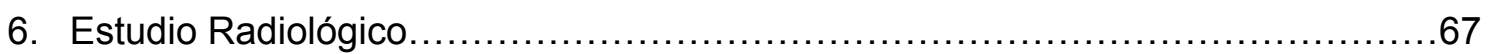

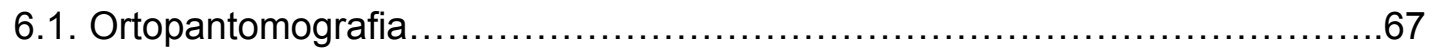

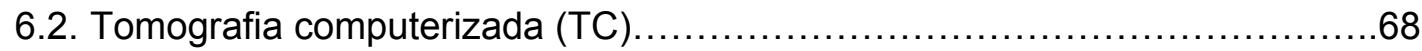

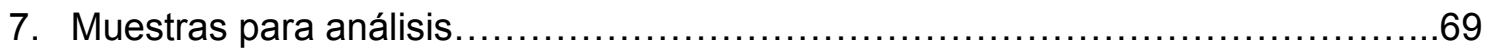

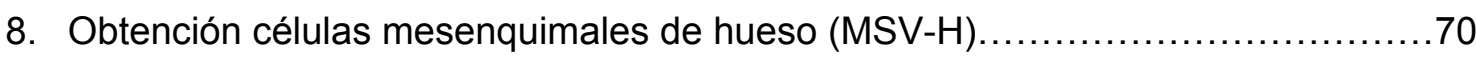

9. Producción de la matriz tridimensional ......................................... 71

- Obtención de suero autólogo ........................................71

- Producción de la matriz tridimensional...................................71

• Liofilización................................................................71

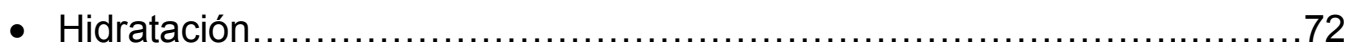

- Tallado de la matriz .................................................... 72

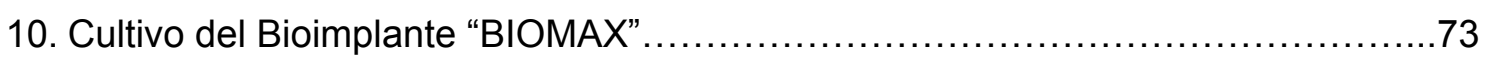

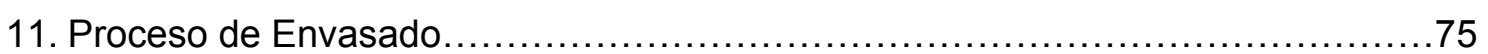

12. Controles de Calidad Bioimplante "BIOMAX" ..................................... 75

- Controles microbiológicos.....................................................

- Análisis fenotípico células MSV-H por citometría de flujo....................78

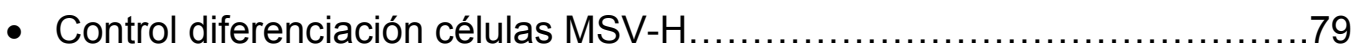

13. Aplicación del Bioimplante "BIOMAX" .......................................... 80

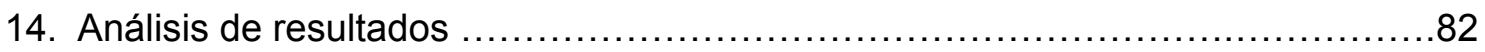




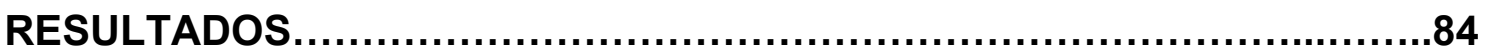

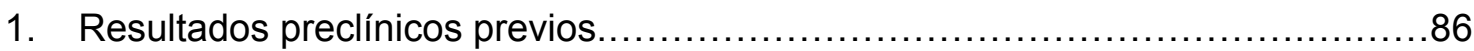

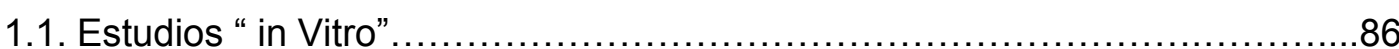

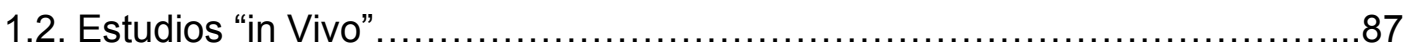

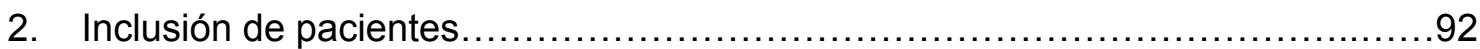

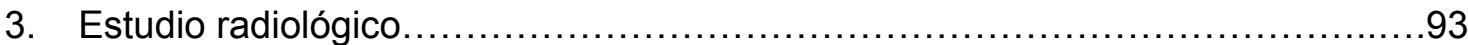

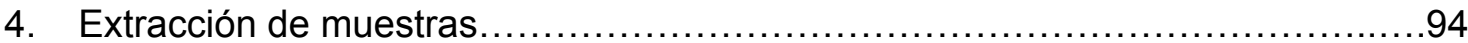

5. Preparación de las células mesenquimales de hueso (MSV-H) .................95

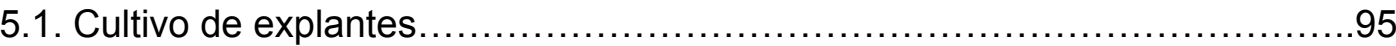

5.2. Cultivo y proliferación de las células MSV-H................................96

5.3. Análisis fenotípico células MSV-H por citometría de flujo....................97

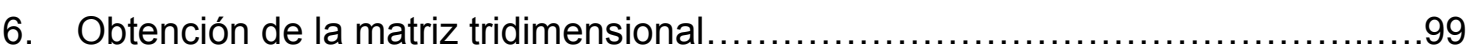

7. Fabricación del bioimplante "BIOMAX" ...........................................

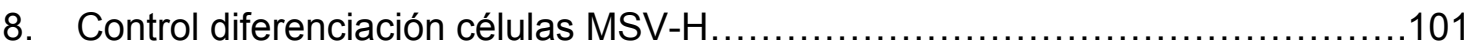

9. Análisis de resultados ......................................................

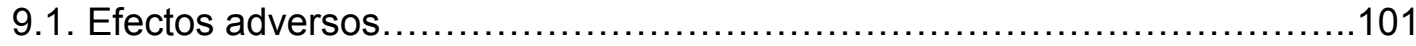

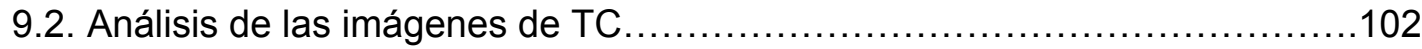

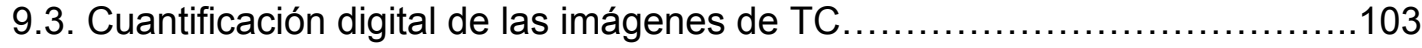

DISCUSIÓN.......................................................................

1. Desarrollo del producto farmacéutico bioimplante "Biomax" ......................115

1.1. Obtención células mesenquimales de hueso (MSV-H) .....................115

1.2. Obtención de la matriz tridimensional........................................... 127

1.3. Cultivo del Bioimplante "Biomax" ............................................. 134

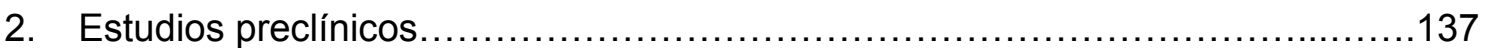

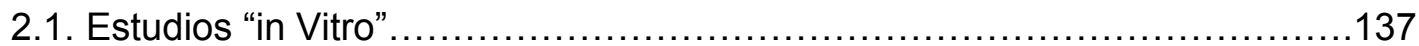

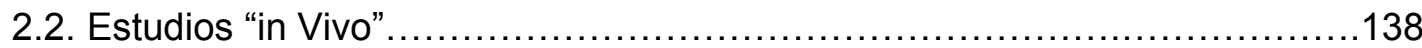

2.3. Diseño del ensayo clínico.................................................146

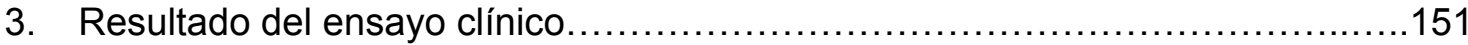

CONCLUSIONES...................................................................

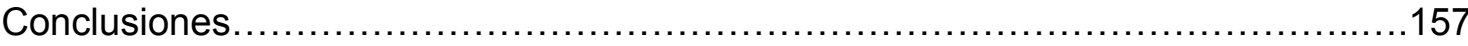

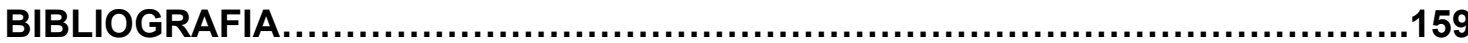




\section{INTRODUCCIÓN ESTADO ACTUAL DEL PROBLEMA}





\section{CELULAS MADRE.}

\subsection{CONCEPTO Y DEFINICIÓN.}

Las células madre, conocidas por su nomenclatura en inglés como stem cells, son células indiferenciadas que presentan dos características principales (Figura 1), que les confieren un gran potencial para su utilización en medicina regenerativa.

1. Son clonogénicas, es decir, son capaces de expandirse por auto-renovación ilimitada mediante división simétrica; generando células madre iguales a sí misma, es decir, generando clones.

2. Pueden diferenciarse hacia diversos linajes celulares mediante divisiones asimétricas, dando origen a una descendencia similar a la original y a otra que puede generar células derivadas de las tres capas embrionarias (ectodermo, mesodermo y endodermo).

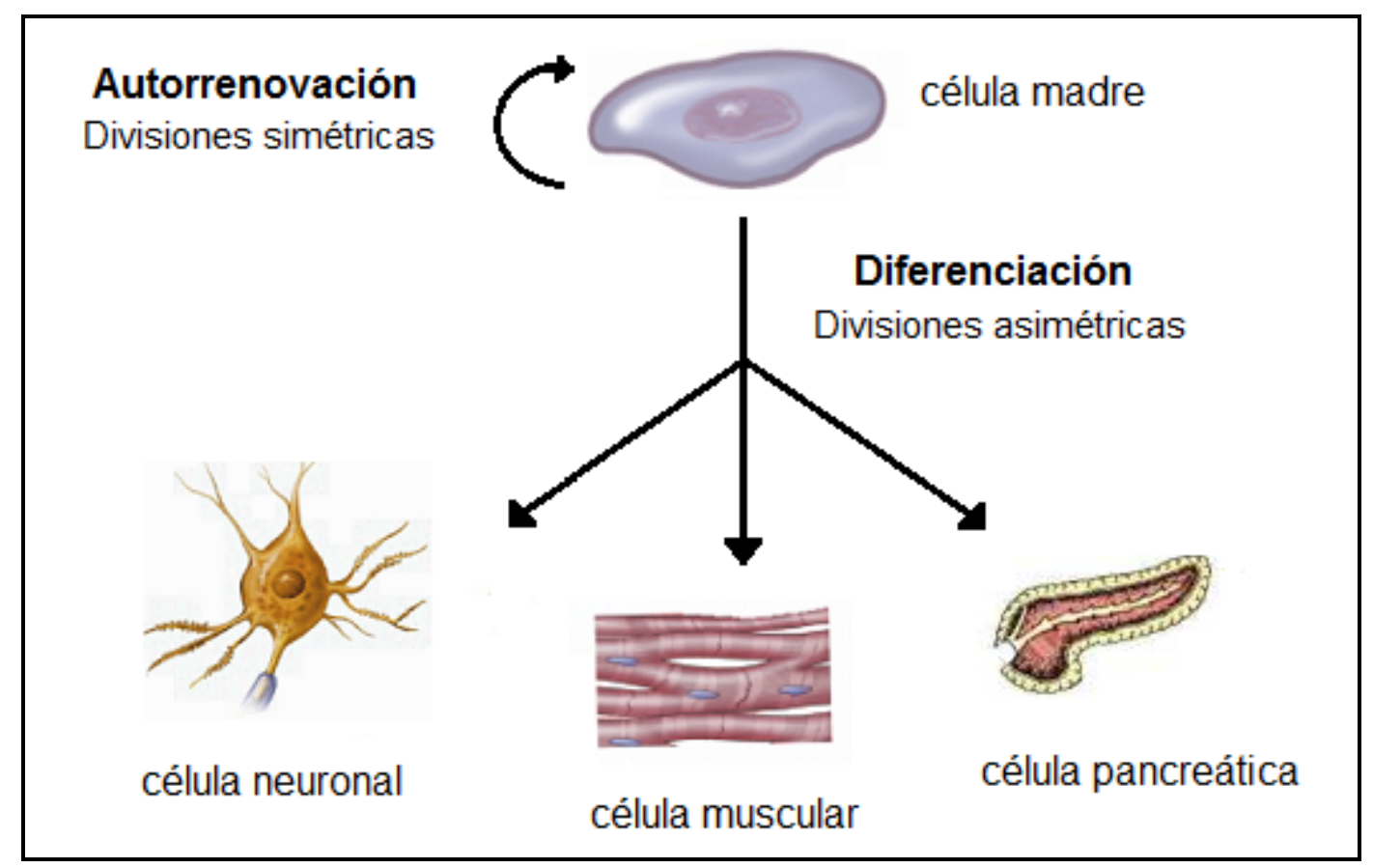

Figura 1: Esquema de las características principales de las células madre. 


\subsection{CLASIFICACION DE LAS CÉLULAS MADRE}

Las células madre se pueden clasificar en función de dos criterios: según su potencialidad para diferenciarse hacia diferentes tejidos y según su origen.

\section{- Células madre según su potencia}

Se diferencian cuatro tipos de células madre en función de la capacidad de diferenciarse hacia distintos tipos celulares (Figura 2):

1. Células madre totipotentes. Son células capaces de generar un organismo completo, incluyendo los componentes embrionarios y extraembrionarios, es decir, pueden generar todas las células del feto y la parte embrionaria de la placenta.

La célula madre totipotente por excelencia es el cigoto, y este mantiene su totipotencia hasta la etapa de 8 a 16 células. Este tipo de células madre tiene un uso restringido en terapia celular por diferentes controversias en cuanto a su potencial carcinogénico, ya que una vez implantadas pueden dar lugar a teratomas o teratocarcinomas, y además presentan el problema ético, que supone trabajar con embriones humanos, ya que muchas corrientes defienden que la vida humana comienza en la fecundación.

2. Células madre pluripotentes. Son las células madre embrionarias aisladas de la masa celular interna del blastocisto; no forman un organismo completo, pero pueden dar lugar a cualquier tipo celular de los tres linajes embrionarios (endodermo, mesodermo y ectodermo) y a las células de la línea germinal. Las células pluripotentes mas estudiadas son las células madre embrionarias (ESC).

3. Células madre multipotentes Son células más comprometidas en el proceso de diferenciación, por lo que sólo pueden generar células de su misma capa embrionaria. Este tipo de células madre permanecen de forma aislada en los tejidos del individuo adulto y son las encargadas de realizar la reparación de los mismos, como ocurre en huesos, epitelios, células de la sangre y músculo esquelético (Becerra y col, 2001). 
Un ejemplo de este tipo celular es una célula madre mesenquimal de médula ósea, que como es de origen mesodérmico daría lugar a células de esta capa como son miocitos, condrocitos, osteocitos y adipocitos.

4. Células madre unipotentes. Son células con un grado de diferenciación muy limitado, que solo consiguen generar un único tipo de células, como por ejemplo, las células madres de la piel.

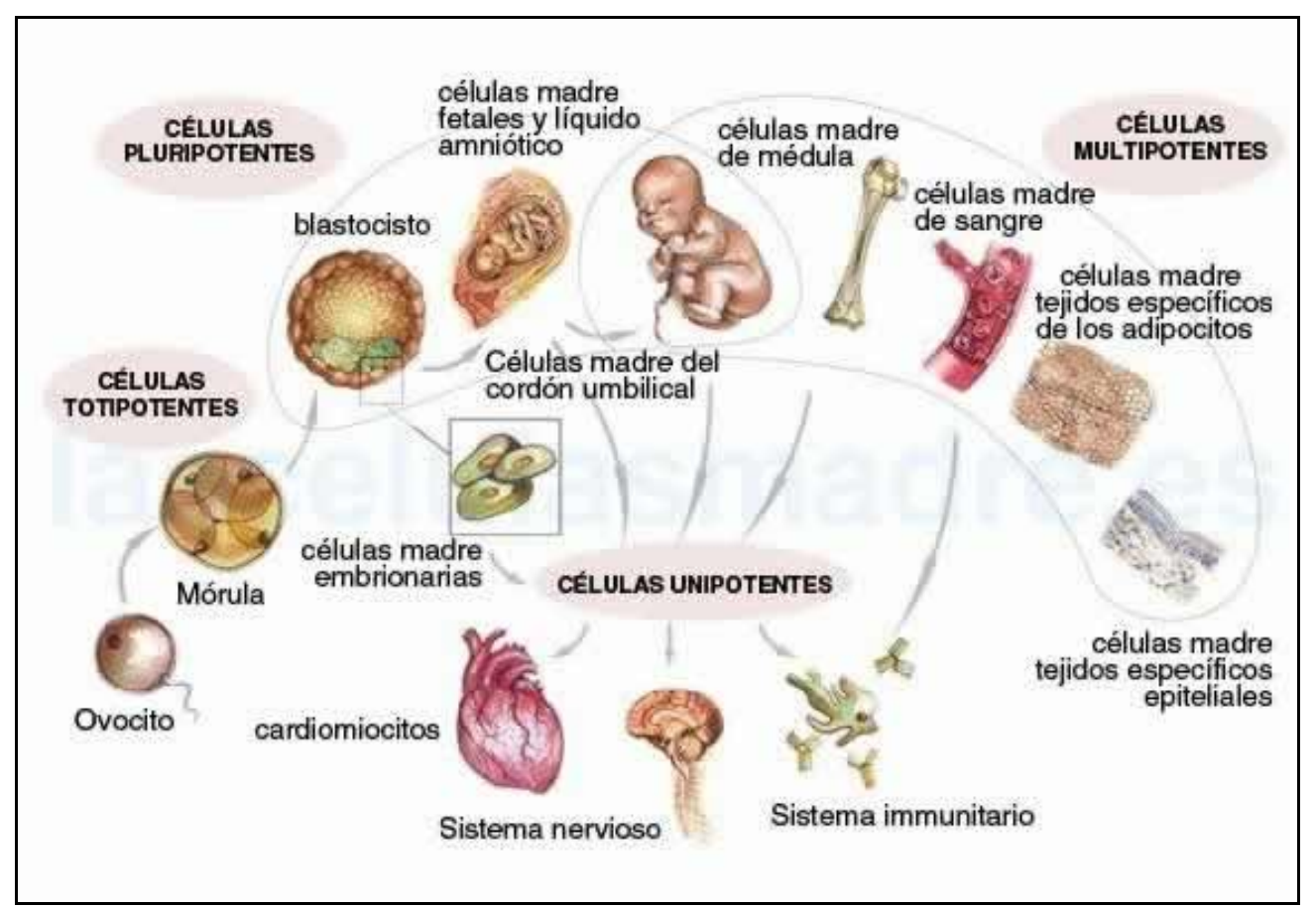

Figura 2: Tipos células madre según su potencialidad para diferenciarse

\section{- Células madre según su origen}

Las células madre según su origen se dividen fundamentalmente en dos grupos: células madre embrionarias y células madre adultas.

1. Células madre embrionarias ("Embryonic stem cells" o ESC): son células pluripotentes que se obtienen a partir de la masa celular interna de un embrión en estado de blastocisto, es decir, de 4 a 7 días tras la fecundación dependiendo de la especie. Estos embriones son obtenidos mediante fecundación in vitro en tratamientos de infertilidad y donados para su uso en investigación (Figura 3). 


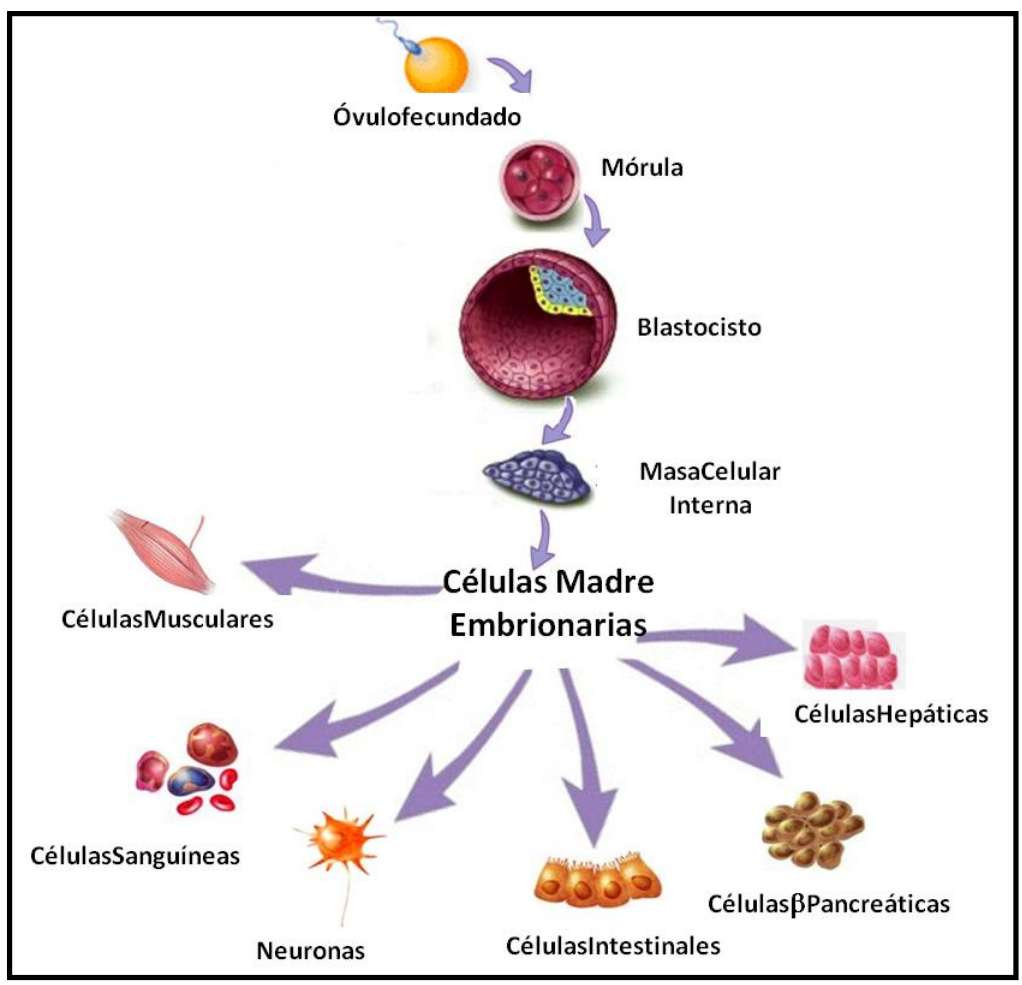

Figura 3: Células madre embrionarias.

Las primeras células madre embrionarias fueron aisladas en 1981 por Evans y Kaufman a partir de blastocistos de ratón, pero hasta 1998 no se anunció el descubrimiento de sus homólogas humanas (Thomson y col, 1998), y de las células embrionarias germinales (Shamblott y col, 1998).

Estas células, una vez aisladas, son cultivadas en el laboratorio sobre un lecho de células de ratón que funcionan como células alimentadoras (feeder layer) (Zaidi y col, 2007). Las células alimentadoras generan un lecho de soporte y suministran factores de crecimiento y citoquinas necesarias para que las células crezcan adecuadamente, mantengan un cariotipo normal y preserven su capacidad de autorrenovación y pluripotencia (Evans y Kaufman, 1981).

Estudios posteriores identificaron el factor inhibidor de la leucemia (LIF, Leukemia Inhibiting Factor) como una de las citoquinas claves liberadas por las células alimentadoras para evitar la diferenciación y mantener la capacidad de autorrenovación de las ESC de ratón (Smith y col, 1988; Arias y col, 2009). En las ESC humanas juegan un papel importante para el mantenimiento de la pluripotencia la Activina/Nodal y del Factor de Crecimiento Fibroblástico básico (bFGF) (Vallier y col, 2009). 
La pluripotencialidad de las ESC las hace ser de gran interés para su uso terapéutico, ya que les confiere la capacidad de diferenciarse hacia cualquier linaje celular de los 200 que están presentes en el organismo. Sin embargo, su utilización clínica puede generar diversos problemas:

- Bioéticos: debido a la necesidad de embriones para su obtención.

- Bioseguridad: ya que poseen un elevado potencial teratogénico.

- Inmuno-histocompatibilidad.

Además, este tipo celular tiene el inconveniente de requerir un lecho de células alimentadoras de ratón para su crecimiento y expansión, lo que implica el riesgo de transmisión de virus murinos, como han demostrado Cobo y col (2008), que con una técnica de microscopia electrónica detectaron la presencia de partículas víricas en el $33 \%$ de los cultivos realizados con fibroblastos embrionarios de ratón.

Desde que se descubrieron las ESC humanas en 1998, se han desarrollado numerosos trabajos de investigación para conocer la biología y los requerimientos necesarios de cultivo para mantener su estado pluripotente.

Para evitar el riesgo trasmisión viral por las células alimentadoras de ratón, se han intentado realizar cultivos con medios condicionados que incluyen los factores liberados por estas como activina, BMP, FGF y el LIF (Nichols y col, 1990; Vallier y col, 2009). Además, se han utilizado células alimentadoras de origen humano, como fibroblastos de piel (Unger y col, 2008; Unger y col, 2009) o células derivadas de la placenta (Miyamoto y col, 2004; Park y col, 2010). Sin embargo, hay estudios comparativos que revelan que las células alimentadoras de origen humano y murino no presentan la misma eficacia (Eiselleova y col, 2008).

Actualmente, para evitar riesgos de zoonosis y reacciones inmunes, se están desarrollando sistemas de cultivo "xeno-free", es decir, sin productos de origen animal (productos o células), utilizando matrices extracelulares, superficies biosintéticas y medios condicionados, lo que facilitaría el uso de estas células en aplicaciones terapéuticas (Desai y col, 2015).

Otro punto a solucionar para la utilización de ESC pluripotentes, es la controversia sobre la utilización de embriones humanos para su obtención. Este aspecto se ha solucionado con la manipulación de células adultas para generar células con pluripotencialidad inducida (iPS). Por lo general, se utiliza 
como célula diana una célula adulta diferenciada que inicialmente no es pluripotente. Por medio de vehículos retrovirales se le transfieren genes exógenos, provenientes de células madre, que codifican factores de transcripción como son: Oct4, Sox2, c-Myc y Klf4. Estos genes son capaces de desdiferenciar la célula diana y reprogramarla hacia la pluripotencialidad (Figura 4). Este tipo celular fue generado por Shinya Yamanaka en el año 2006 a partir de fibroblastos de ratón. Posteriormente, el mismo grupo obtuvo iPS in vitro a partir de fibroblastos humanos, utilizando la misma combinación de factores de transcripción: Oct4, Sox2, c-Myc y Klf4 (Takahashi y col, 2007), descritos posteriormente por otros autores (Miller y col 2011). De forma simultánea, un grupo de Estados Unidos ha desarrollado iPS humanas con la combinación de genes Oct4, Sox2, Nanog y LIN28 vehiculizados en lentivirus (Yu y col, 2007) y no utilizando el gen cMyc que es oncogénico. Por todo ello, actualmente existen diferentes tendencias sobre la utilización de los genes de pluripotencialidad.

Otros trabajos muestran que la secuencia WNT/ $\beta$ catenina y Nanog son los reguladores clave de la pluripotencia de las ESC y la reprogramación de las células somáticas (Marucci L, 2014), a diferencia de los primeros estudios de Yamanaka que se pensaba que Nanog era dispensable.

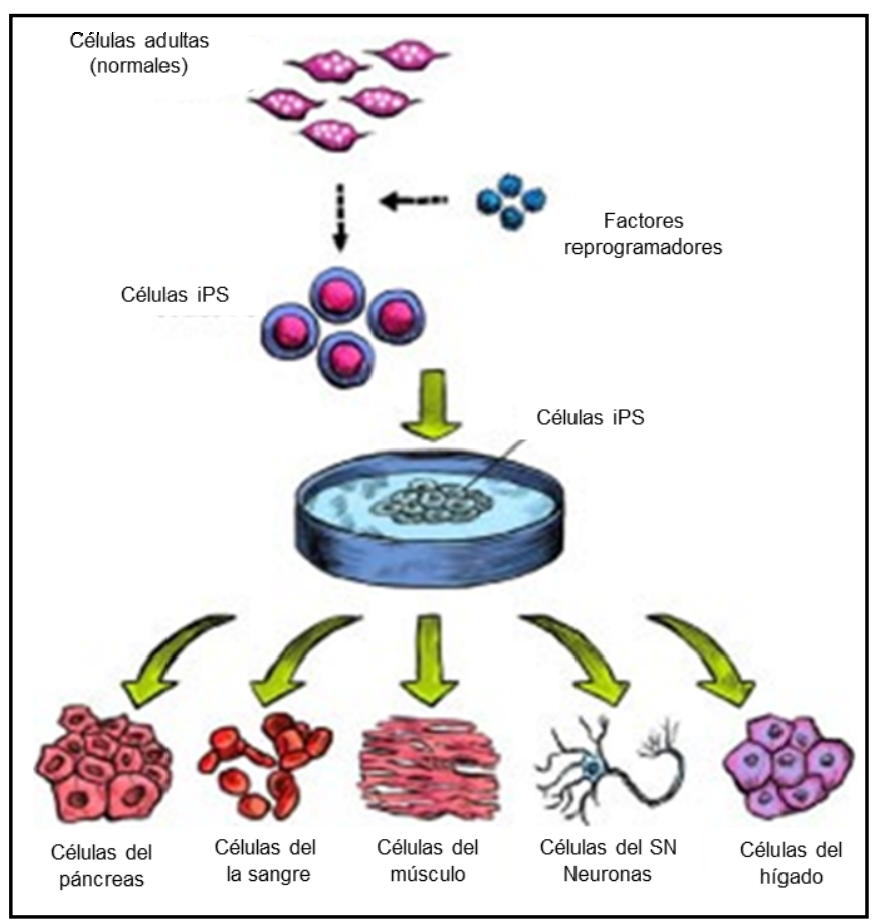

Figura 4: Obtención IPS. 
En la actualidad se pueden obtener iPS a partir de diferentes tipos celulares como pueden ser las células linfoblastoides, lo que supone un gran recurso biológico para aplicaciones de medicina regenerativa (Barret y col, 2014).

Recientemente, se ha publicado que ya es posible reprogramar células adultas de ratón y generar células madre pluripotentes inducidas in vivo, como demuestra el grupo del Dr. Serrano, cuyas células son más semejantes a las ESC que las células iPS obtenidas in vitro; ya que la reprogramación in vivo confiere un estado de pluripotencialidad en la que además de generar células de las tres capas embrionarias, se pueden generar células del trofoblasto, por lo que tienen características de células totipotentes (Abad y col, 2013).

Las iPS presentan ventajas importantes respecto a las células madre embrionarias:

1. no generan rechazo inmunológico, ya que se pueden obtener a partir de las células del propio paciente.

2. no requieren la utilización de óvulos humanos.

3. se obtienen fácilmente.

Sin embargo, hay trabajos que indican que pueden ser más tumorigénicas que las células madre embrionarias (Gutierrez-Aranda y col, 2010).

2. Células madre adultas. Son células madre no diferenciadas que poseen la capacidad de clonarse creando copias de sí mismas y de diferenciarse para dar lugar a las células adultas del tejido en el que se encuentran, por lo tanto, son multipotentes. Se encuentran en diferentes órganos y tejidos. En el hombre se conocen 20 tipos distintos de células madre adultas y su función es regenerar los tejidos que poseen un desgaste constante como son la piel o la sangre, o reparar tejidos dañados como el hígado.

Las células madre adultas más conocidas son las células madre mesenquimales (Mesenchymal Stem Cells, MSC). Estas células se originan a partir del mesodermo embrionario, presentan una morfología fibroblástica y tienen la capacidad de diferenciarse hacia diversos tipos celulares como osteocitos, condrocitos y adipocitos, cuando se mantienen en un ambiente condicionado. 
Los primeros trabajos se realizaron con MSC aisladas de la médula ósea (Friedenstein y col, 1966), pero actualmente pueden obtenerse a partir de diferentes tejidos: tejido adiposo, músculo, tendón, pulpa dental, ligamento periodontal, sangre del cordón umbilical, placenta, periostio, hígado, tejido cartilaginoso, líquido sinovial, bazo e hígado (Arthur y col, 2009).

\subsection{CELULAS MADRE MESENQUIMALES.}

\section{- Concepto y definición.}

Las células madre mesenquimales (MSC) también conocidas como células madre estromales, son células multipotentes obtenidas de tejidos adultos. Tienen morfología fibroblastoide y derivan del mesodermo embrionario. Son capaces de diferenciarse a diferentes tipos celulares (osteocitos, condrocitos, adipocitos, mioblastos, cardiomiocitos, neuronas y astrocitos), tanto in vivo como in vitro. (Pittenger y col, 1999; Jori y col, 2005; Chen y col, 2008; Tokcaer-Keskin Zeynep y col, 2009)

Las MSC se pueden aislar, cultivar y manipular in vitro fácilmente (Beyer y col 2006), ya que se adhieren a las superficies plásticas. En la literatura se pueden encontrar muchos métodos diferentes de aislamiento y expansión de MSC, lo que aumenta la dificultad de realizar estudios comparativos. La Sociedad Internacional de Terapia Celular ha recomendado una serie de criterios mínimos que debe tener una célula para ser considerada una MSC humana (Horwitz y col, 2005; Dominici y col, 2006) (Figura 5). Estos criterios son:

1. Ser adherentes al plástico en condiciones estándar de cultivo.

2. Presentar expresión positiva de los marcadores de superficie CD105, CD73 y CD90; y no presentar marcadores hematopoyéticos como CD34, CD45, CD11a, CD19 y HLA-DR.

3. Ser capaces de diferenciarse in vitro a osteocitos, condrocitos y adipocitos bajo condiciones específicas de cultivo.

Inicialmente, las MSC se obtenían principalmente de la médula ósea ya que están presentes en el estroma de este tejido. Su papel es contribuir a la regeneración de los tejidos mesenquimáticos (hueso, cartílago, músculo, ligamento, tendón, tejido adiposo y estroma). 
El estroma de la médula ósea es un tejido compuesto por células no hematopoyéticas (adipocitos, fibroblastos, células endoteliales, macrógados,...) que generan un microambiente determinado mediante la liberación de diversos factores necesarios para la hematopoyesis, es decir, el estroma actúa como "feeder" para las células hematopoyéticas.

En la actualidad se extraen MSC de una amplia variedad de tejidos, lo que facilita su utilización terapéutica. Por ejemplo: tejido adiposo (Zuk y col, 2002; Wagner y col, 2005), músculos, tendón y diferentes tejidos dentales como: ligamento periodontal, pulpa dental, papila dental y folículo dental (Huang y col, 2009; Tran Hle y col, 2014, Alkhalil y col, 2015), sangre del cordón umbilical (Olson y col, 2015), placenta (Sabapathy y col 2012), periostio, tejido cartilaginoso, líquido sinovial, bazo e hígado (Arthur y col, 2009). Pueden incluirse en la relación incluso cerebro, corazón, pulmón y riñones. (Salem y col, 2010). La obtención de las MSC a partir de los diferentes tejidos adultos requiere procedimientos más o menos traumáticos e invasivos; sin embargo, en un último trabajo Rossignoli y col (2013) obtienen MSC a partir de la sangre menstrual y del endometrio decidual, lo que podría representar una fuente de células madre muy prometedora para aplicaciones de terapia celular.

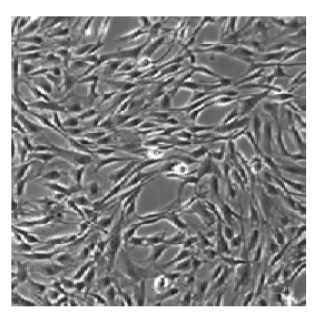

Células adherentes

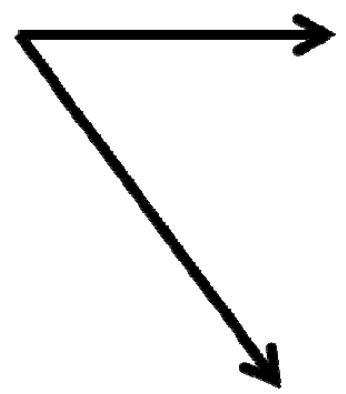

Adipo

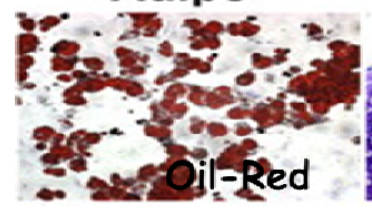

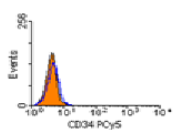

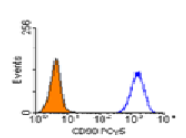

Marcadores de superficie
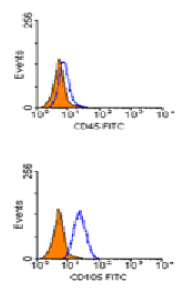

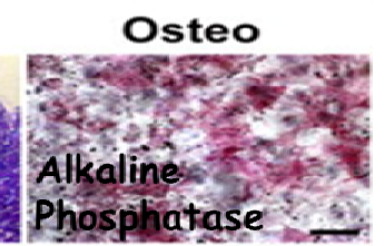

Diferenciación

Figura 5: Características células mesenquimales humanas. 


\section{- Terapia Celular con células madre mesenquimales.}

Las MSC son un recurso terapéutico muy prometedor ya que poseen una gran plasticidad, capacidad inmunorreguladora (Uccelli y col, 2006, Patel y col, 2008; Shi y col, 2011) y se obtienen fácilmente. Se ha postulado su utilidad en medicina regenerativa para una gran diversidad de enfermedades como el Parkinson, Alzheimer, lesiones de médula espinal, enfermedades cardiacas, derrames cerebrales, quemaduras y osteoartritis entre otras (Park y col, 2014; Joyce y col, 2010; Kin y col, 2015; Gnecchi y col,2012; Dulamea, 2015; Koźlik y col, 2014; Orozco y col, 2011; Orozco y col, 2013; Orozco y col, 2014; Vega y col, 2015).

Se ha postulado también que las MSC utilizadas junto con la Ingeniería Tisular, nos permitirán conseguir órganos y tejidos de repuesto para sustituir aquellos que se van deteriorando. Destaca, por ejemplo, la utilización de diferentes tipos de biomateriales combinados con las MSC para la regeneración de tejido óseo y cartílago (Petite y col, 2000; Gallego y col, 2010; Grayson y col, 2015).En la Figura 6 se resumen las investigaciones realizadas con MSC para uso clínico.

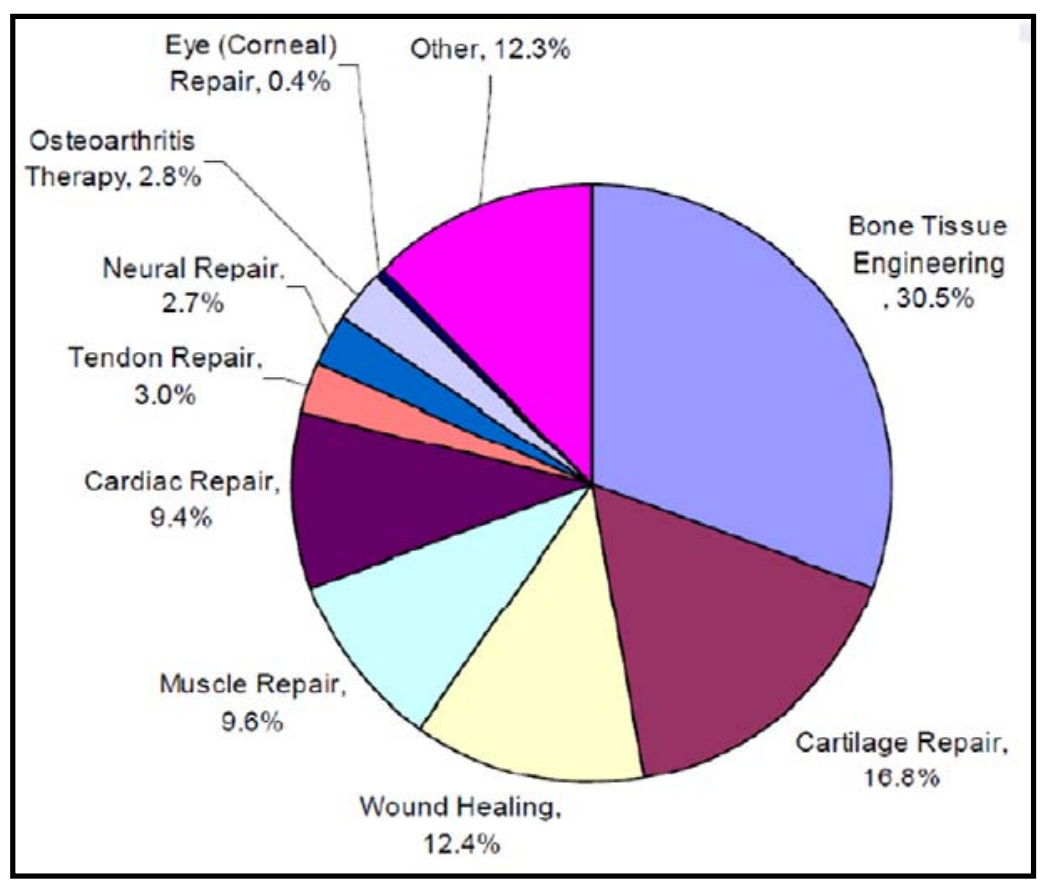

Figura 6: Investigaciones realizadas con células mesenquimales para uso clínico. (Mesenchymal Stem Cells, Advances and Applications, Bioinformant 2010) 
Las MSC presentan desventajas respecto a las ESC, ya que no son pluripotentes y tienen una capacidad de expansión más limitada. Sin embargo, la utilización de MSC de tejidos adultos presenta muchas ventajas diferentes:

1. El propio paciente es el donante y el receptor de las células, es decir, se pueden utilizar células autólogas, lo que soluciona los problemas de histocompatibilidad y de rechazo.

2. Al utilizar una fuente celular de tejidos adultos, no se requiere la destrucción de embriones, y no hay ocasión para controversias en cuestiones éticas y morales.

3. Las MSC adultas presentan un mayor grado de diferenciación respecto a las células embrionarias, lo que significa un menor riesgo tumorigénico.

4. Finalmente, existe más experiencia, resumida en numerosos ensayos clínicos, 101 registrados en la FDA (Helmy y col, 2010); con resultados preliminares satisfactorios. Sin embargo, todavía no ha pasado tiempo suficiente para obtener conclusiones definitivas, ya que la mayoría de los ensayos son en fase I y II, y con un número reducido de pacientes. (Fernandez Vallone y col, 2013).

De todos los ensayos clínicos desarrollados con MSC, el $51 \%$ se han realizado con MSC de medula ósea, frente al $7 \%$ que utilizan MSC de tejido adiposo. Aproximadamente el $48 \%$ se han realizado con células autólogas frente al $42 \%$ con células alogénicas (Helmy y col, 2010). El frecuente uso de células alogéncas se explica porque las MSC generan un rechazo inmunológico mínimo ya que presentan una inmunogenicidad limitada (Horwitz y col, 2002; Uccelli y col, 2006; Griffin y col, 2010, Ankrum y col, 2014), aumentando su utilización hasta al $73 \%$ en el 2012 (Mendicino y col, 2014).

\section{TEJIDO ÓSEO.}

\subsection{CONCEPTO Y DEFINICIÓN.}

El tejido óseo es un tipo tejido conectivo que se caracteriza por tener un componente extracelular calcificado, lo que le aporta rigidez y resistencia a la tracción y a la comprensión. 
El tejido óseo es el componente principal de los huesos, por lo que forma la mayor parte del esqueleto, soportando el cuerpo y protegiendo los órganos, además de permitir nuestro movimiento.

Las principales funciones del tejido óseo son:

- Soporte. Es un lugar de fijación para los músculos y tendones.

- Protección. Los huesos forman cavidades como el cráneo y la caja torácica que protegen los órganos internos, cerebro, pulmones y corazón, de cualquier traumatismo.

- Homeostasis mineral. El tejido óseo es un depósito de minerales, especialmente el calcio y el fósforo, muy importantes en funciones como la contracción muscular. Cuando se necesitan el hueso los libera al torrente sanguíneo para que se distribuyan por el organismo.

- Hematopoyesis En la cavidad de los huesos largos, vértebras, costillas, esternón, huesos del cráneo, cintura escapular y pelvis se encuentra la médula ósea roja que produce la sangre porque contiene células madre que originan los tres tipos de células sanguíneas: leucocitos, hematíes y plaquetas.

- Reserva. En el interior de los huesos largos se encuentra la médula ósea amarilla compuesta por adipocitos y hematíes dispersos, lo que la convierte en una fuente de reserva energética.

\subsection{ESTRUCTURA DEL TEJIDO ÓSEO.}

Morfológicamente el tejido óseo presenta ciertas similitudes con el tejido cartilaginoso, ya que ambos están constituidos por células rodeadas por una matriz extracelular amorfa. Las células del hueso (osteocitos) se localizan en unos espacios llamados osteoplastos o lagunas lenticulares, y todo el conjunto se encuentra rodeado de una capa de tejido conectivo fibroso que es el periostio. Su estructura se conoce a partir de la "Ciencia general de los tejidos" del médico y anatomista francés Xavier Bichat (1771-1802).

Macroscópicamente se diferencian dos tipos de tejido óseo (Figura 7): compacto y esponjoso o laminar. 


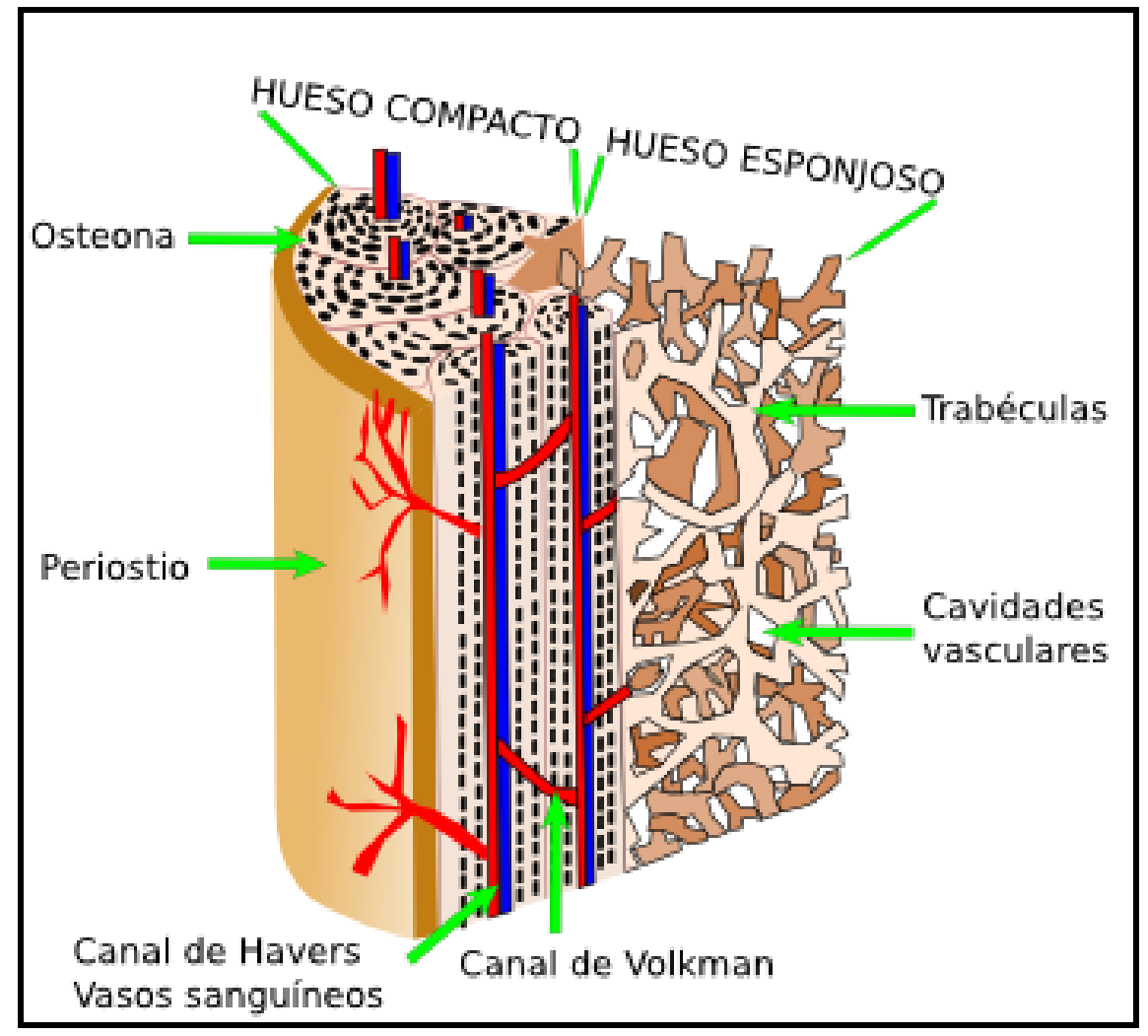

Figura 7: Estructura del tejido óseo.

\section{- Tejido óseo compacto.}

Está formado por una masa compacta sin espacios y se encuentra en la parte externa de los huesos y en la diáfisis de los huesos largos. Este tejido presenta una estructura de anillos concéntricos o laminillas de matriz mineralizada alrededor de los canales de Havers, que se extienden longitudinalmente y se comunican entre sí por los llamados canales de Volkmann que perforan el periostio. Estos dos tipos de canales permiten la distribución por el tejido óseo de vasos sanguíneos (aportan oxígeno y nutrientes y eliminan sustancias de desecho), linfáticos y nervios. Entre las laminillas concéntricas se encuentran las lagunas lenticulares donde se ubican los osteocitos. Cada laguna tiene una serie de canalículos donde se extienden las prolongaciones de los osteocitos para conectarse entre sí y con los canales de Havers. 
El conjunto de un canal central, las láminas concéntricas que lo rodean, las lagunas, los canalículos y los osteocitos incluidos se denomina osteona o sistema de Havers, y su diámetro varia de 100 a $400 \mu \mathrm{m}$. Finalmente, las láminas que se encuentran entre las osteonas se denominan láminas intersticiales.

\section{- Tejido óseo esponjoso o laminar.}

Está constituido por finas trabéculas de sustancia esponjosa compuestas por hueso laminar sin vasos, que se entrecruzan dando lugar a un entramado en forma de red, cuyos espacios están intercomunicados y albergan la médula ósea roja. Este tejido se encuentra en la porción central de los huesos planos y en las epífisis de los huesos largos.

\subsection{CÉLULAS DEL TEJIDO ÓSEO.}

El tejido óseo tiene diferentes tipos celulares (Figura 8):

\section{- Células osteogénicas.}

Son células no especializadas originadas a partir de las células mesenquimáticas primitivas, que forman una población de células troncales encargadas de originar los osteoblastos y osteocitos. Estas células tienen una morgología fusiforme con citoplasma poco prominente y se encuentran en la capa interna del periostio (tejido que rodea los huesos) y del endostio (tejido que delimita cavidad medular del hueso y los canales de los conductos de Havers).

\section{- Osteoblastos.}

Son células osteoformadoras que han perdido la capacidad de dividirse por mitosis y están encargadas de sintetizar y secretar los componentes orgánicos de la matriz ósea para el crecimiento, mantenimiento y reparación del hueso. La formación de la matriz se lleva a cabo por la secreción de colágenos y otros materiales. El depósito de las sales de calcio, que aportan la dureza se produce entre 8 y 10 días después de que se hayan liberado las moléculas de tropocolágeno. 
Los osteoblastos se encuentran en las superficies de los huesos y a medida que van liberando los materiales que forman la matriz ósea van quedando rodeados por ella en las lagunas lenticulares pasando a ser osteocitos. Como células principalmente secretoras, presentan un complejo de Golgi desarrollado con numerosas mitocondrias con gránulos de fosfato tricálcico y un retículo endoplasmático rugoso (RER) muy desarrollado, con cisternas dilatadas y gran número de ribosomas. En el citoplasma también aparecen vacuolas con contenido amorfo, inclusiones lipídicas y lisosomas. Estas células contienen fosfatasa alcalina que genera un aumento de la concentración de calcio y fósforo.

\section{- Osteocitos.}

Son las células más abundantes del tejido óseo, constituyendo el $95 \%$ del componente celular de dicho tejido. Se originan a partir de los osteoblastos cuando pierden la capacidad de síntesis y secreción; esta transformación ocurre aproximadamente cada tres días (Bozal, 2006). Se encuentran en las lagunas lenticulares rodeados de matriz ósea calcificada, y su función es realizar el intercambio de nutrientes y productos de desecho. Realizan además el mantenimiento del estado de la matriz ósea y el intercambio de calcio con la sangre. Los osteocitos son células alargadas con numerosas prolongaciones que permiten la comunicación intercelular; tienen un núcleo central ovoide y citoplasma basófilo. Presentan un complejo de Golgi y un RER menos desarrollado que los osteoblastos, con escasas mitocondrias, lisosomas e inclusiones de lípidos y glucógeno.

\section{- Osteoclastos.}

Son células derivadas de monocitos circulantes que se asientan sobre la superficie del hueso donde realizan la reabsorción del tejido óseo. Participan en los procesos de remodelación de los huesos durante los procesos de crecimiento y reparación ósea. Los osteoclastos son células multinucleadas de gran tamaño $(100 \mu \mathrm{m})$ y móviles, situadas entre las trabéculas óseas a reabsorber y un capilar. La cara relacionada con las trabéculas se sitúa en el interior de las "lagunas de Howship" (lagunas formadas durante el proceso de reabsorción) y presenta un borde estriado por la presencia de microvellosidades, mientras que la cara contraria es lisa. Cada núcleo se 
relaciona con un complejo de Golgi hacia la cara lisa y contienen abundantes lisosomas y vacuolas con cristales de hidroxiapatita. Los lisosomas son los encargados de secretar enzimas capaces de atacar la matriz del hueso y liberar el calcio atrapado en ella.

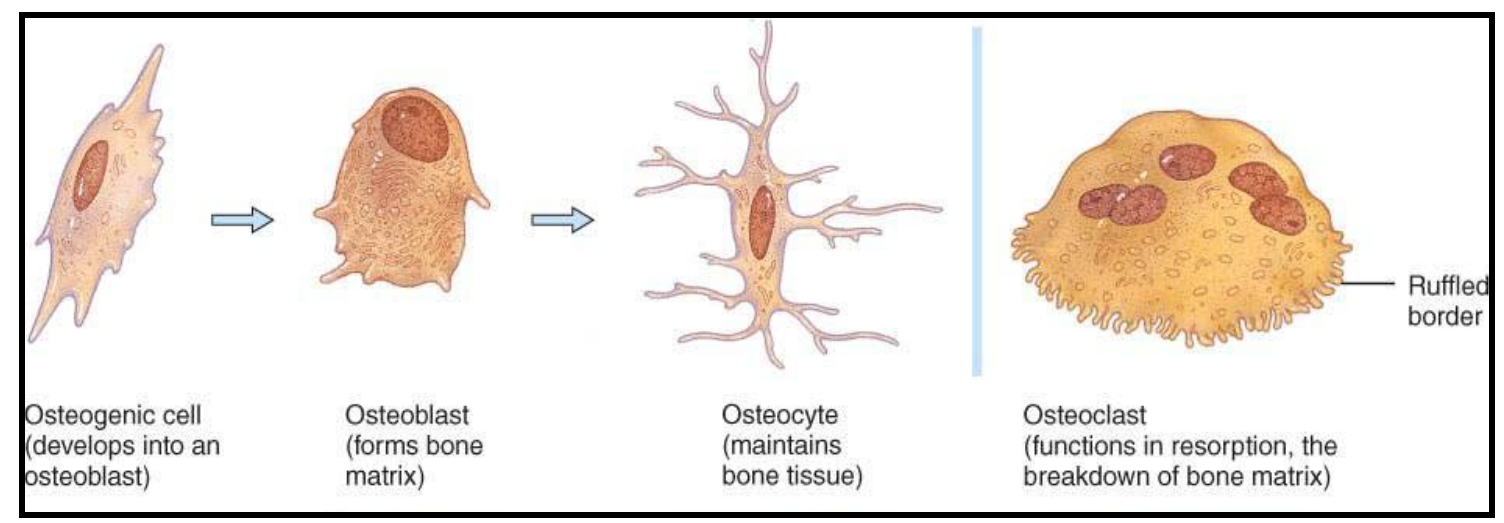

Figura 8: Tipos celulares del tejido óseo.

\subsection{MATRIZ ÓSEA.}

La matriz ósea está constituida por componentes orgánicos e inorgánicos.

Los componentes orgánicos descritos en 1853 por Virchow, están formados en un $90 \%$ por fibras de colágeno, principalmente tipo I, que se asocian entre si formando fascículos paralelos de unas $15 \mu \mathrm{m}$, lo que aporta cierto grado de elasticidad y resistencia a las fuerzas de tensión. Además del colágeno, entre los componentes orgánicos aparecen proteoglucanos (condroitin y queratan sulfato), glucosaminoglucanos y glucoproteínas. Además, osteonectina, osteopontina y osteocalcina responsables de la mineralización de la matriz ósea. La osteonectina es una glicoproteína ligada al calcio, que mantiene las uniones entre las fibras de colágeno y la porción mineral del hueso; la osteopontina es la encargada del anclaje de los osteoclastos a la matriz mineral de los huesos y la osteocalcina fija el calcio a la matriz ósea. Ver Tabla 1. 
Los componentes inorgánicos están constituidos en un $65 \%$ por depósitos de fosfato cálcico cristalino (hidroxiapatita). Contiene además iones como magnesio, sodio, potasio, citrato y carbonato cálcico. Las sales minerales se depositan por cristalización en el entramado de las fibras de colágeno durante el proceso de calcificación o mineralización, proceso responsable de la dureza de la matriz.

Tabla 1: Proteínas de la matriz ósea.

\begin{tabular}{|c|c|}
\hline COLÁGENO & - Tipo I, II, V y XII \\
\hline PROTEOGLICANOS & $\begin{array}{l}\text { - Condrotin sulfato } \\
\text { - Decorina } \\
\text { - Biglicano } \\
\text { - Hialuronano }\end{array}$ \\
\hline $\begin{array}{l}\text { PROTEINAS CON ACIDO Y- } \\
\text { CARBOXI-GLUTÁMICO }\end{array}$ & $\begin{array}{l}\text { - Osteocalcina } \\
\text { - Proteína de la matriz con ácido } \text { У-Carboxi-glutámico }\end{array}$ \\
\hline GLICOPROTEINAS & 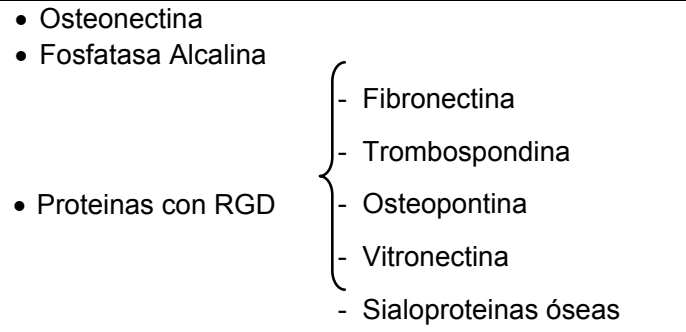 \\
\hline PROTEINAS DEL PLASMA & $\begin{array}{l}\text { - Albúmina } \\
\text { - A2-SH-glicoproteina }\end{array}$ \\
\hline $\begin{array}{l}\text { FACTORES DE } \\
\text { CRECIMIENTO }\end{array}$ & $\begin{array}{l}\text { - IGF-I y II (Insulin growth factor I y II) } \\
\text { - TGF- } \beta \text { (Transforming growth factor -beta) } \\
\text { - PDGF (Platelet derived growth factor) }\end{array}$ \\
\hline
\end{tabular}

(Fernandez-Tresguerres-Hernandéz-Gil, 2006)

\subsection{FORMACIÓN DEL HUESO.}

El proceso de formación del hueso se denomina osificación y puede ser de dos tipos: intramembranosa y endocondral.

\section{- Osificación intramembranosa.}

La osificación intramembranosa aparece en los huesos planos, especialmente en el cráneo; y se desarrolla a partir del mesénquima. 
En un primer estadio, aparece un tejido mesenquimatoso constituido por células estrelladas que forman una estructura membranosa. Este tejido es invadido por numerosos capilares, que irrigan la zona, de forma que las células mesenquimatosas se transforman en células osteogénicas, que darán lugar a los osteoblastos que inician la producción de la matriz ósea que se calcifica y se convierten en osteocitos. Esta osificación da lugar al tejido óseo primario, y por la remodelación de los osteoclastos se genera el tejido óseo adulto.

\section{- Osificación endocondral.}

La osificación endocondral tiene lugar fundamentalmente en los huesos largos y se caracteriza porque el tejido cartilaginoso hialino es sustituido por hueso.

En una primera fase, las células mesenquimatosas se diferencian a condroblastos que sintetizan la matriz cartilaginosa. En una siguiente fase, se produce un aumento y maduración de los condrocitos y la calcificación de los mismos debido a un depósito de sales de hidroxiapatita. En la zona calcificada se genera una vascularización a partir del pericondrio que lleva nutrientes y oxígeno a las células de esta zona. Estas células se diferencian a células osteogénicas y posteriormente a osteoblastos, que producen matriz ósea sobre los restos del cartílago calcificado.

\subsection{REMODELACIÓN DEL TEJIDO ÓSEO.}

El tejido óseo es un tejido dinámico que se encuentra en una fase de remodelación constante. El remodelado óseo existe durante toda la vida, entre 5-10\% del hueso total al año, es decir, nuestro esqueleto se renueva totalmente cada 10 años. El balance entre la reabsorción y el remodelado, está influido por numerosos factores genéticos, mecánicos, vasculares, nutricionales, hormonales y locales. Hasta los 30 años existe un balance positivo entre remodelación y reabsorción, entre los 30 y los 50 se tiene la máxima masa ósea y a partir de aquí, predomina la reabsorción y la masa ósea empieza a disminuir (Fernandez-Tresguerres-Hernandéz-Gil, 2006). El proceso de remodelación ósea se divide en 5 fases (Figura 9): 


\section{Fase quiescente}

Esta es la fase en la que se encuentra el hueso en reposo. Hasta el momento no se conocen los factores que inician el proceso se remodelado, éste ocurre de forma fisiológica, ya que el hueso es un tejido en fase de remodelación continua, pero también se puede desencadenar cuando el hueso sufre una agresión.

\section{Fase de activación}

Esta fase se inicia con la activación de la superficie del hueso debido a "señales" no bien conocidas, entre las que figuran una serie de cambios en las fuerzas mecánicas locales, en la situación endocrinológica del individuo, en el ambiente paracrino de la zona a remodelar e incluso cambios en la estructura del hueso por el propio envejecimiento o por una agresión o daño. Antes de iniciarse la reabsorción, las células limitantes, es decir, los osteoblastos situados en el endostio, se retraen, y por acción de colagenasas se digiere la membrana endóstica, quedando la superficie mineralizada expuesta a la acción de los osteoclastos circulantes, que se fijan a las proteinas de la matriz ósea (fibronectina y vitronectina).

\section{Fase de reabsorción}

En esta fase, los osteoclastos activos comienzan a disolver la matriz mineral y a descomponer la matriz osteoide. Este proceso lo finalizan los macrófagos, y permite la liberación de los factores de crecimiento contenidos en la matriz, principalmente TGF- $\beta$, PDGF e IGF-I y II.

\section{Fase de formación}

Durante esta fase, las células osteoprogenitoras se agrupan en las zonas reabsorbidas por atracción quimiotáctica de los factores de crecimiento liberados durante la reabsorción (Lind y col, 1995). Estos factores estimulan la proliferación de las células osteoprogenitoras, que sintetizan una sustancia cementante sobre la que se forma el nuevo tejido. Además expresan proteínas morfogenéticas óseas (BMPs) que inducen su diferenciación hacia osteoblastos, que inician la síntesis de sustancia osteoide. 


\section{Fase de mineralización}

La mineralización de la matriz ósea comienza a los 30 días del depósito de la sustancia osteoide y finalizará a los 130 días en el hueso cortical o compacto y a los 90 en el hueso trabecular. Una vez finalizada esta fase, el hueso vuelve a la fase quiescente o de descanso.

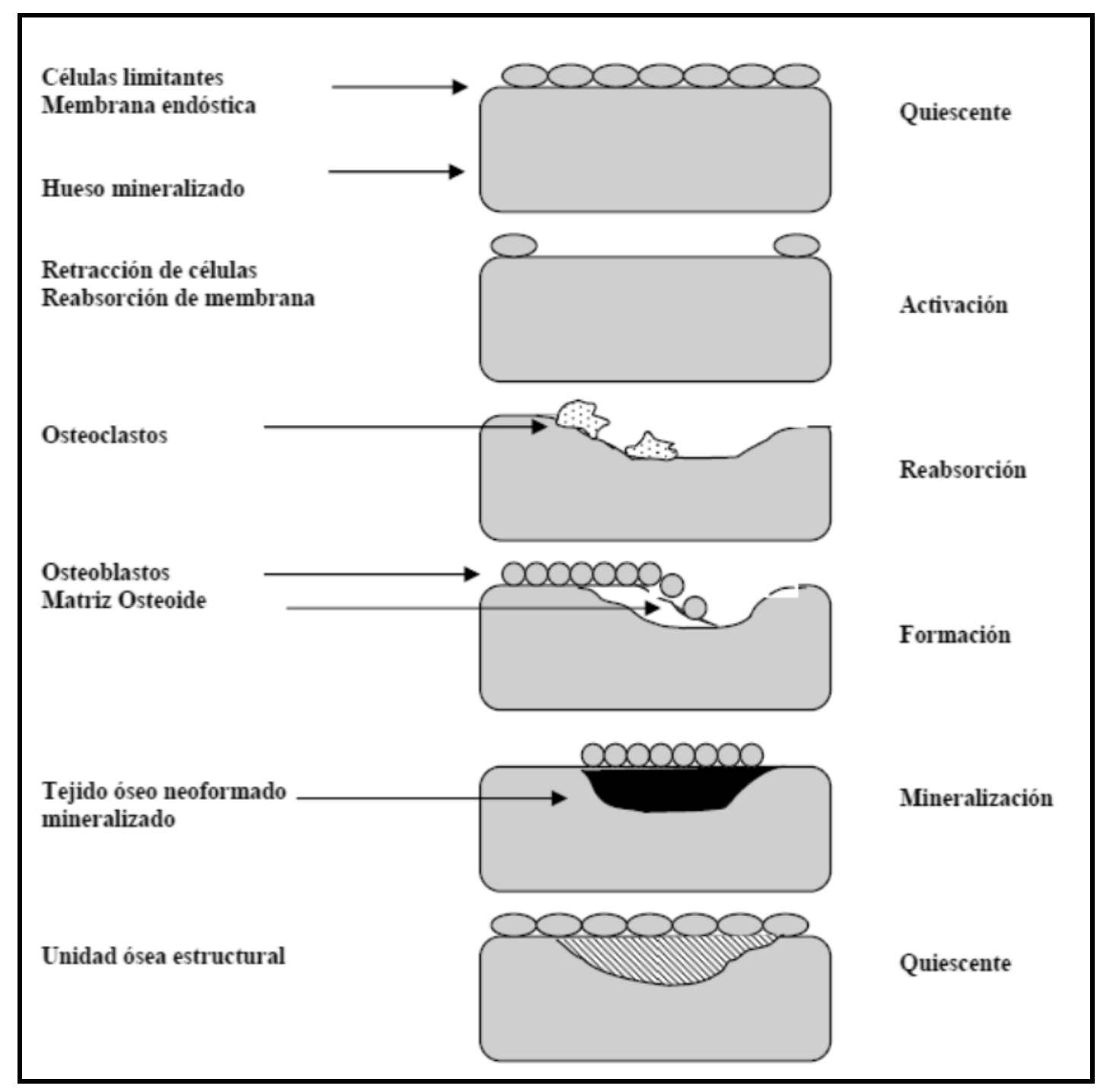

Figura 9: Proceso de remodelado óseo. (Fernandez-Tresguerres-Hernandéz-Gil, 2006) 


\section{DEFECTOS ÓSEOS.}

La reconstrucción de defectos óseos producidos por traumatismos y otras etiologías (resecciones tumorales, malformaciones, quistes, infecciones...) es una cuestión de notable importancia en el mundo actual, dado el número de daños en las articulaciones y fracturas óseas que se producen por accidentes o en la práctica deportiva. Este hecho, tiene gran importancia en el campo de la cirugía maxilofacial, donde se incluye la pérdida de hueso asociada a la edad que origina alteraciones estéticas y funcionales.

En función del defecto a reparar se pueden utilizar diferentes tratamientos para restaurar la forma y la función ósea, pero los más comunes son los injertos óseos, que pueden ser autoinjertos (del mismo individuo), aloinjertos (individuos diferentes de la misma especie) o xenoinjertos (individuos de diferentes especies). Cada tipo de injerto tiene sus limitaciones (Reynolds, 2010). La distracción ósea y los procedimientos con injertos microvasculares han demostrado ser la mejor opción para la reparación de defectos de mayor tamaño y complejidad en la región facial, pero tampoco están exentos de limitaciones y desventajas.

Hasta el momento, el mejor sustituto del hueso es el propio hueso, es decir, el trasplante autólogo (Hennessey y col, 2005; Infante-Cossio y col, 2007), donde donante y receptor coinciden. Este tipo de trasplante es el más utilizado desde inicios del siglo $\mathrm{XX}$, ya que no presenta problemas inmunológicos. Es considerado el "gold standard " en la reconstrucción ósea porque se transplanta un tejido vivo, es decir, con células (Handschel, 2006), lo que le hace ser un material osteoinductivo (libera BMPs y otros factores de crecimiento que estimulan las células osteogenicas), osteogénico (posee células osteogénicas que forman el nuevo tejido) y osteoconductivo (permite el crecimiento y vascularización del lecho del receptor hacia el interior del injerto) (Dimitriou y col, 2011; Cab Chan, 2014). Sin embargo, la utilización de autoinjertos presenta desventajas, ya que es necesario realizar una intervención adicional para su obtención y, a pesar de los avances en el diagnóstico por imagen, los métodos anestésicos y la técnica quirúrgica, los pacientes siguen experimentando una morbilidad significativa de la 
zona donante. Si el injerto se obtiene de la cresta iliaca, el dolor dura 6 semanas e incluso el $10 \%$ de los pacientes sufre dolor durante más de dos años. (Younger y col, 1989). Por otro lado, existen limitaciones en cuanto a la obtención debido a la escasez de zonas de hueso donante.

Una alternativa a considerar son los aloinjertos obtenidos de donantes muertos, lo que soluciona la escasez de material en cuanto a formas y tamaños (Nandi, 2010), debido a la existencia de bancos de tejidos. En este punto, el factor limitante para el éxito del aloinjerto es su obtención y almacenamiento. Existe, además, la posibilidad de rechazo inmunológico.

Estos injertos presentan varias desventajas. En primer lugar tienen en comparación con los autoinjertos una menor capacidad osteoconductiva y osteoinductiva, lo que alarga el tiempo de regeneración. También tienen menor capacidad osteogénica, porque no poseen un componente celular, ya que se desvitalizan por irradiación o congelación/liofilización para evitar la transmisión de agentes infecciosos (Habibovic, 2007). El segundo punto importante, es que presentan un balance negativo entre la tasa de reabsorción del injerto alogénico y la formación de nuevo tejido, lo que conlleva la posibilidad de fracturas y la no integración del injerto realizado. A pesar de sus desventajas, se utilizan fundamentalmente por su disponibilidad y porque se consideran biocompatibles (Tortolini y col, 2012).

Los xenoinjertos son otro sustituto a considerar. En este caso es un injerto de otra especie y la principal desventaja es el rechazo imnunológico y la posibilidad de transmisión de agentes infecciosos. En este apartado, destaca la utilización de huesos bovinos (Thorwarth y col, 2006; Maiorana y col, 2011), o porcinos (Barone y col, 2008) liofilizados o desminalizados.

Otra opción eficiente para la reparación del tejido óseo son las técnicas de distracción ósea, desarrollada desde 1905 con un cruento método descrito por Codivila que utilizó la técnica para alargar las extremidades inferiores. Esta técnica se basa en la creación de hueso neoformado y tejidos blandos adyacentes entre dos segmentos de hueso que se van separando de forma gradual y controlada mediante un distractor. Esta separación genera un estrés tensional que permite la formación de hueso, y otros tejidos circundantes como: piel, fascia, músculos, 
tendones, encía, mucosa oral, vasos y nervios; como demostró Gavriil Ilizarov en 1989. (Lugo-Martínez 2010). El mayor inconveniente de esta técnica es la necesidad de realizar varias intervenciones y la dificultad para controlar el vector de distracción en los defectos óseos complejos. Sin embargo, es un método eficaz para el tratamiento de defectos mandibulares (Guerrero y col, 1995; Vila-Morale y col, 2011).

Por último, la utilización de colgajos microvasculares es la mejor solución para defectos amplios de hueso y tejido blando en la región craneo-maxilofacial. En esta técnica se utilizan injertos autólogos con pedículo vascular propio, que se transfiere y se anastomosa a las estructuras vasculares de la zona del defecto. Esta técnica permite reconstrucciones de estructuras complejas con mejores resultados estéticos y funcionales que otras técnicas convencionales, ya que el colgajo garantiza una irrigación óptima, resultando en una integración completa del injerto, lo que garantiza resultados estables con mejor calidad para el paciente (NavarroVilla y col, 2002; Brito-Pereira y col, 2012).

Sin embargo, esta técnica también presenta desventajas. Por ejemplo, para la obtención y trasplante del colgajo se requiere un mayor tiempo quirúrgico, con dos equipos de cirujanos; además, la zona donante presenta una co-morbilidad con un déficit permanente cuando se incluye tejido muscular en el colgajo (recto abdominal) o un fragmento de hueso (peroné o cresta iliaca). (Colletti y col, 2014).

La Ingeniería Tisular, ha emergido recientemente como técnica alternativa para la reparación de los defectos óseos. Esta, combina células como las MSC o células osteogénicas maduras, con soportes tridimensionales o matrices biocompatibles, de forma que en conjunto se obtiene una estructura tridimensional similar al tejido. Esto facilita la reparación de los defectos y permite obtener mejores resultados que con las opciones convencionales de tratamiento (Dimitriou y col, 2011). 


\section{INGENIERIA TISULAR}

\subsection{CONCEPTO Y DEFINICIÓN}

El término de Ingeniería Tisular, se utilizó por primera vez en 1987 para definir una nueva ciencia multidisciplinar que se basa en la utilización de células vivas. La manipulación del entorno extracelular para la creación de sustitutos biológicos y su implantación en el cuerpo para reparar, reemplazar, mantener o mejorar la función de un órgano o tejido dañado (Falke y col, 2000). (Figura 10).

La creciente necesidad de órganos, unida al breve periodo de viabilidad de los mismos y su posible rechazo, a pesar de los avances en la terapia imnunosupresiva, hace que la Ingeniería Tisular sea considerada como un tratamiento médico ideal, ya que utiliza la combinación de tres herramientas básicas: células, soporte y factores de crecimiento, usados o no de forma simultánea, lo que favorece la reparación del tejido dañado (Ikada, 2006).

Las primeras investigaciones se realizaron con células de origen autólogo, que no generan rechazo inmunológico, lo que evita la necesidad de terapia inmunosupresora. En este punto, las células mesenquimales, con un gran potencial osteogénico, junto a las células de la médula ósea, las células de periostio y los osteoblastos, han sido la primera opción para la reparación del tejido óseo. (Drosse y col, 2008).

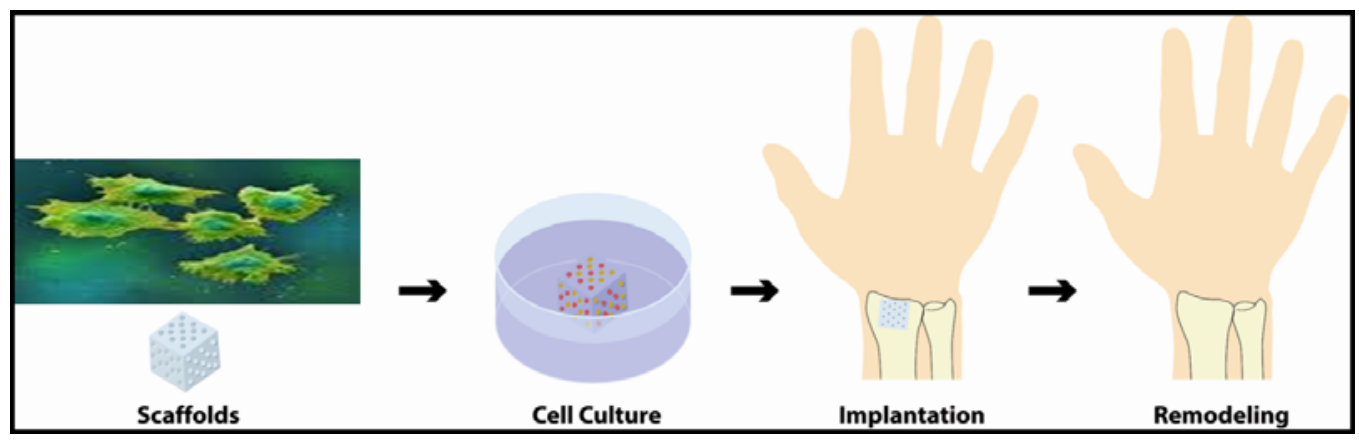

Figura 10: Bases de la Ingeniería Tisular. (Drosse y col, 2008) 
Como ya hemos visto, actualmente se utilizan diferentes tejidos como fuente de MSC. Sin embargo, in vitro las MSC crecen en monocapa, mientras que el hueso presenta una estructura tridimensional. De aquí surge la necesidad de desarrollar una estructura o matriz que permita a las células crecer en un ambiente tridimensional adecuado para reemplazar el tejido dañado. (Salgado y col, 2004).

A pesar de los avances y mejoras que se han producido en este campo durante los últimos años, la matriz "ideal” para la ingeniería tisular ósea no ha sido desarrollada todavía. Las matrices generadas con biovidrios unidos a células mesenquimales (Destch y col, 2014), las formadas por láminas de diferentes biomateriales (Kon y col, 2014) o los hidrogeles generados con sistemas de biplotting son alternativas muy atractivas para las aplicaciones biomédicas. Estos últimos pemiten obtener una estructura definida que favorece la angiogénesis (Zchnder y col, 2015) y la unión de fármacos a dichas matrices (Martínez-Vázquez y col, 2015; Paris y col, 2015).

\subsection{MATRICES TRIDIMENSIONALES}

La matriz tridimensional es crucial para el éxito de la ingeniería tisular ósea, ya que aporta un ambiente adecuado para la migración de células ostogénicas, facilita la proliferación y la diferenciación en su interior y además promueve la formación de hueso nuevo y mantene una competencia mecánica durante la regeneración del mismo (Fröhlich y col, 2008).

\section{- Propiedades de la matriz}

En ingeniería tisular una matriz es un soporte o andamio que acomoda las células y las guía en su crecimiento y regeneración tridimensional de los tejidos. (Yang y col, 2001).

Las propiedades esenciales deseables para una matriz son (Salgado y col, 2004):

- Biocompatibilidad. Deben integrarse en el organismo receptor sin generar respuesta inmunológica. 
- Porosidad. Las matrices deben ser porosas y permeables a las células, con poros abiertos intercomunicados entre sí para aumentar la superficie expuesta al cultivo celular y facilitar la distribución de las células en su interior.

El tamaño de poro debe estar en un rango de 200 a $900 \mu \mathrm{m}$, para permitir la penetración celular, la formación de matriz extracelular y la neovascularización en las áreas centrales de la matriz, a partir de los tejidos circundantes.

- Propiedades de superficie. Debe tener características químicas y topográficas que permitan adhesión y proliferación celular. Las características químicas se relacionan con la capacidad de las células de adherirse al material y mantener interacciones con las proteínas de la matriz. Las características topográficas son muy interesantes para los procesos de osteoconducción que facilitan la colonización de la matriz por células de los tejidos adyacentes.

- Osteoinductividad. Capacidad para reclutar células osteogénicas del hueso sano para estimular la diferenciación osteogénica y la formación de nuevo tejido.

- Propiedades mecánicas. La matriz debe aportar resistencia mecánica para soportar la presión y mantener la forma requerida para el crecimiento celular y la producción de matriz extracelular.

- Biodegradabilidad. Es esencial que la matriz se degrade de forma paulatina a medida que se forma el nuevo tejido y que los productos de degradación no sean tóxicos y se eliminen fácilmente.

Actualmente existen diferentes métodos para la fabricación de las matrices porosas (Chen y col, 2002) como hidrogeles, espumas generadas con $\mathrm{CO}_{2}$ a altas presiones, extrusión de fibras que generan matrices con diferentes tamaños de poro, técnicas de prototipado rápido (Leukers y col, 2005), separación de fases, liofilización y lixiviación o extracción sólido-líquido (Tran y col, 2011). 


\section{- Biomateriales}

Un biomaterial se define como un material ideado para interaccionar con los sistemas biológicos para evaluar, tratar, aumentar o substituir cualquier tejido, órgano o función del cuerpo. Actualmente existen diversos tipos de biomateriales para producir una matriz o soportes celulares. La selección del material apropiado para es muy importante para el éxito de la matriz; en este punto tenemos una gran diversidad: metales, cerámicas o polímeros naturales o sintéticos; o la combinación de ellos (Tabla 2).

- Metales. Son materiales ampliamente utilizados en el campo de la medicina ortopédica para generar endoprotesis. Los implantes metálicos son de acero inoxidable, aleaciones de cobalto y cromo, y de titanio o aleaciones del mismo. Estos materiales presentan una desventaja importante para su utilización ya que no son biodegradables, y se pueden corroer con el tiempo.

- Cerámicas. Son ampliamente utilizadas en el campo de la ingienería tisular ósea debido a su bioactividad y por la semejanza estructural con la fase mineral del hueso (Plazas-Bonilla y col, 2011). Las apatitas, y más específicamente la hidroxiapatita (HA) (Martinez-Valencia y col, 2008; Sulaiman y col, 2013), aunque presentan alta fragilidad, poseen buenas propiedades físicas. Son resistentes a la temperatura, a la corrosión y al desgaste. Son materiales de elevada dureza. Por su parte, la alúmina y la zirconia, (Bose y col, 2002; Song y col, 2014) tienen aplicación en ortopedia por ser muy resistentes al desgaste. Las cerámicas biodegradables pueden clasificarse en cerámicas de fosfato tricálcico (TCP) y biovidrios.

- Polímeros. Los clásicos son de origen natural como el colágeno, el chitosan (Abarrategi y col, 2010), el almidón o los glicosaminoglicanos. También puedes ser de origen sintético como el ácido poliláctico (PLA) o el ácido poliglicólico (PGA), ampliamente utilizados en suturas reabsorbibles. Los polímeros presentan la ventaja que son biodegradables y biocompatibles lo que facilita la adhesión, migración y diferenciación celular, así como la deposición de matriz extracelular. Sin embargo, los polímeros naturales tienen la desventaja de poder generar respuesta inmunológica, y un riesgo de trasmisión viral cuando son de origen animal (Panseri y col, 2011). 
Tabla 2: Tipos de biomateriales, características y aplicaciones clínicas en regeneración ósea. (Velasco- Peña y col, 2010)

\begin{tabular}{|c|c|c|c|c|}
\hline Composición & Tipo & Origen & Aplicaciones clínicas & Propiedades \\
\hline $\begin{array}{l}\text { Fosfatos de calcio } \\
\text { Ej: hidroxiapatita, } \\
\text { fosfato tricalcico, } \\
\text { fosfato de } \\
\text { octacalcio }\end{array}$ & Cerámico & Sintético & $\begin{array}{l}\text { Regeneración ósea, de sitios sin } \\
\text { carga mecánica, relleno de } \\
\text { defectos óseos (cementos, } \\
\text { gránulos, recubrimientos) }\end{array}$ & $\begin{array}{l}\text { Adhesión de tejido } \\
\text { óseo (bioactividad), } \\
\text { biodegradable, tasa de } \\
\text { degradación variable }\end{array}$ \\
\hline $\begin{array}{l}\text { Fosfatos de calcio } \\
\text { base silício } \\
\text { (biovidrios) }\end{array}$ & $\begin{array}{l}\text { Vidrios } \\
\text { cerámicos }\end{array}$ & Sintético & $\begin{array}{l}\text { Regeneración ósea, de sitios sin } \\
\text { carga mecánica, relleno de } \\
\text { defectos óseos (gránulos, } \\
\text { recubrimientos) }\end{array}$ & $\begin{array}{l}\text { Adhesión de tejido } \\
\text { óseo (bioactividad), } \\
\text { biodegradable }\end{array}$ \\
\hline $\begin{array}{l}\text { Alumina (óxido de } \\
\text { aluminio) }\end{array}$ & Cerámico & Sintético & $\begin{array}{l}\text { Reemplazo de articulaciones } \\
\text { (rodilla, hombro) }\end{array}$ & $\begin{array}{l}\text { Alta resistencia a la } \\
\text { tensión, resistencia a la } \\
\text { fatiga, sin adhesión de } \\
\text { tejido óseo, alta } \\
\text { resistencia a la fatiga, } \\
\text { baja fricción }\end{array}$ \\
\hline $\begin{array}{l}\text { Titanio y sus } \\
\text { aleaciones }\end{array}$ & Metal & Sintético & $\begin{array}{l}\text { Reemplazo de hueso en sitios } \\
\text { con carga mecánica. Prótesis } \\
\text { dentales o de cadera, vertebras }\end{array}$ & $\begin{array}{l}\text { Adhesión de tejido } \\
\text { óseo (bioactividad) en } \\
\text { algunos casos. } \\
\text { Resistente a la } \\
\text { corrosión. Alta } \\
\text { resistencia mecánica }\end{array}$ \\
\hline $\begin{array}{l}\text { Acero inoxidable, } \\
\text { aleaciones de } \\
\text { cobalto y cromo }\end{array}$ & Metal & Sintético & $\begin{array}{l}\text { Reemplazo de hueso en sitios } \\
\text { con carga mecánica, prótesis } \\
\text { dentales y de cadera, verrtebras y } \\
\text { fijaciones }\end{array}$ & Corrosión a largo plazo \\
\hline Polimetilmetacrilato & Polímero & Sintético & $\begin{array}{l}\text { Reemplazo de hueso en zonas } \\
\text { con carga mecánica, relleno de } \\
\text { defectos óseos (cemento óseo). } \\
\text { Fijación de prótesis de cadera y } \\
\text { vertebroplastia }\end{array}$ & No degradable \\
\hline $\begin{array}{l}\text { Poliesteres como el } \\
\text { ácido polilactico, } \\
\text { ácido poliglicólico, } \\
\text { policaprolactona y } \\
\text { poliuretano. }\end{array}$ & Polímero & Sintético & $\begin{array}{l}\text { Fijación degradable de hueso, } \\
\text { hilo de sutura, relleno de } \\
\text { defectos óseos, regeneración } \\
\text { tejido blando y liberación } \\
\text { controlada de fármacos }\end{array}$ & $\begin{array}{l}\text { La tasa de degradación } \\
\text { y las propiedades } \\
\text { mecánicas se pueden } \\
\text { controlar variando su } \\
\text { peso molecular }\end{array}$ \\
\hline $\begin{array}{l}\text { Polietileno de ultra } \\
\text { alto peso molecular }\end{array}$ & Polímero & Sintético & $\begin{array}{l}\text { Componente de } \text { prótesis } \\
\text { articulares en la zona de } \\
\text { movimiento relativo (junta) }\end{array}$ & $\begin{array}{l}\text { Capacidad de } \\
\text { lubricación }\end{array}$ \\
\hline $\begin{array}{l}\text { Tereftalato de } \\
\text { polietileno }\end{array}$ & Polímero & Sintético & $\begin{array}{l}\text { Cemento y relleno de defectos } \\
\text { óseos. }\end{array}$ & $\begin{array}{l}\text { La tasa de degradación } \\
\text { y las propiedades } \\
\text { mecánicas se pueden } \\
\text { controlar variando su } \\
\text { peso molecular. } \\
\text { Bioactivo }\end{array}$ \\
\hline Polietilenglicol & Polímero & Sintético & $\begin{array}{l}\text { Excipiente en fármacos y } \\
\text { alimentos. Reparación de tejidos } \\
\text { duros y blandos }\end{array}$ & $\begin{array}{l}\text { Gel acuoso inyectable } \\
\text { y degradable }\end{array}$ \\
\hline Coral & Mineral & $\begin{array}{l}\text { Natural } \\
\text { (animal) }\end{array}$ & Relleno de defectos óseos & $\begin{array}{l}\text { Alta interconexión, } \\
\text { biodegradable }\end{array}$ \\
\hline $\begin{array}{l}\text { Matriz ósea } \\
\text { desmineralizada }\end{array}$ & Proteína & $\begin{array}{l}\text { Natural } \\
\text { (humano) }\end{array}$ & $\begin{array}{l}\text { Relleno de defectos, } \\
\text { regeneración de cartílago }\end{array}$ & $\begin{array}{l}\text { Biodegradable, fuente } \\
\text { natural de proteínas } \\
\text { osteoinductivas (BMPs) }\end{array}$ \\
\hline Colágeno & Proteína & $\begin{array}{l}\text { Natural } \\
\text { (bovino) }\end{array}$ & $\begin{array}{l}\text { Reparación de tejidos duros y } \\
\text { blandos }\end{array}$ & Biodegradable \\
\hline
\end{tabular}


Actualmente existen también combinaciones de los diferentes tipos de biomateriales, Tanodekaew y col (2013) combinan una matriz de HA y PLA; Kon y col (2014) estudian una matriz trilaminar de colágeno e HA. Otro punto a destacar en los biomateriales, es su combinación con diferentes sustancias como factores de crecimiento (BMPs, TGF- $\beta$, IGF, FGF, PDGF, VEGF) (Jansen y col, 2005) que promueven la penetración de células en la matriz y su colonización, así como la generación de hueso nuevo (Blackwood y col, 2012). También favorecen la neovascularización del implante (Suárez-González y col, 2014).

\section{ENSAYOS CLINICOS (EC).}

\subsection{CONCEPTO Y DEFINICIÓN}

Un ensayo clínico es la evaluación experimental de un producto, sustancia, medicamento, técnica diagnóstica o terapéutica que, en su aplicación a seres humanos, pretende valorar su eficacia y seguridad. Por evaluación experimental se entiende la realizada con un medicamento no autorizado, fuera de las condiciones especificadas en la ficha técnica del mismo o fuera de las condiciones habituales de utilización. La Ley 29/2006 en el artículo 58.1 y la ICH BPC en el punto 1.32 definen el EC como "Toda investigación efectuada en seres humanos para determinar o verificar los efectos clínicos, farmacológicos y/o demás efectos farmacodinámicos, y/o identificar cualquier reacción adversa, y/o de estudiar la absorción, distribución, metabolismo y excreción de uno o varios medicamentos en investigación con el propósito de determinar su seguridad y/o su eficacia".

Los EC se realizan para:

- Conocer los efectos farmacodinámicos o recoger datos referentes a su absorción, distribución, metabolismo y excreción del medicamento a estudio en el organismo humano.

- Establecer la eficacia para una indicación terapéutica, profiláctica o diagnóstica determinada.

- Conocer el perfil de reacciones adversas y establecer su seguridad. 
Al ser un estudio realizado en humanos, el EC debe cumplir los siguientes aspectos fundamentales:

- Ser éticamente correcto

- Presentar una metodología adecuada, que incluye un diseño correcto, objetivos concretos en función de la hipótesis formulada y un análisis estadístico adecuado.

- Cumplir con todos los requerimientos legales.

Es obligatorio para todo EC cumplir con las normas de Buena Práctica Clínica (BPC) para garantizar 1) que se vela por los derechos, seguridad y bienestar del sujeto que participa en un ensayo, 2) que los datos recogidos son exactos y fiables y 3) que las autoridades reguladoras aceptaran los datos del ensayo.

El cumplimiento de las BPC obliga a que todos los medicamentos en investigación se fabriquen, manejen y almacenen de acuerdo a las Normas de Correcta Fabricación (NCF, en inglés GMP) pertinentes. Además, los medicamentos en investigación se deben utilizar sin salirse del protocolo aprobado.

La Guía de BPC de la Conferencia Internacional de Armonización (ICH BPC) es una Norma Internacional de calidad científica y ética dirigida al diseño, realización, registro y redacción de informes de ensayos clínicos que implican la participación de los seres humanos (para más información visitar el siguiente enlace http://www.aemps.gob.es/industria/inspeccionBPC/docs/guia-BPC_octubre2008.pdf)

Además, los EC deben realizarse de acuerdo con los principios éticos establecidos en:

- $\quad$ Código de Nuremberg (1947): estableció el consentimiento voluntario del sujeto como imprescindible para realizar experimentos en humanos.

- Declaración de Helsinki (1964) (10ª revisión Seúl, 2008): propone los principios éticos para orientar a los médicos y a las personas que realizan investigación médica en seres humanos. 
- Informe Belmont (1978): es un informe creado por Departamento de Salud, Educación y Bienestar de los Estados Unidos, que explica y unifica los principios éticos básicos para usar sujetos humanos en la investigación: respeto, beneficencia y justicia.

\subsection{CLASIFICACION DE LOS ENSAYOS CLÍNICOS.}

La clasificación de los ensayos clínicos se puede realizar en función de diferentes factores (Tabla 3). Los diferentes tipos no son incompatibles, sino que se combinan entre sí para desarrollar el ensayo clínico ideal, más fiable, riguroso y reproducible.

En el proceso de investigación clínica, destacamos la clasificación según el desarrollo clínico de un medicamento que consiste en cuatro fases, que siguen a una previa investigación, que se realiza en el laboratorio para diseñar, desarrollar y estudiar el comportamiento "in vitro "del medicamento a estudio, y una segunda investigación preclínica en animales que nos permite obtener los primeros resultados del comportamiento "in vivo" de dicho medicamento.

Clasificación según el desarrollo clínico:

- Fase 1. Es el primer paso en la investigación de un medicamento en humanos. Durante esta fase se administra por primera vez el medicamento a estudio en un grupo reducido de voluntarios (no más de 100) para obtener información sobre la toxicidad, farmacodinamia y farmacocinética; es decir, sobre la seguridad del producto en estudio. Se comprueba, así mismo, que la intervención propuesta es factible.

- Fase II. Es el segundo estadio en la evaluación de un medicamento, se realizan en un grupo de entre 100 y 200 pacientes. Su objetivo es realizar medidas preliminares de la relación eficacia terapéutica/toxicidad (rango terapéutico o margen de seguridad), así como establecer la dosis óptima o sus límites de variación en la condición a tratar. Normalmente son ensayos controlados y aleatorizados, ya que para conocer la eficacia del producto a estudio se compara con un tratamiento control (fármaco establecido o placebo). 
- Tabla 3: Clasificación de los Ensayos Clínicos

\begin{tabular}{|c|c|c|}
\hline $\begin{array}{l}\text { Factor de } \\
\text { clasificación }\end{array}$ & Tipos & Definición \\
\hline \multirow{4}{*}{ Desarrollo clínico } & Fase I & Primer contacto: factibilidad y seguridad \\
\hline & Fase II & Evaluación del medicamento: eficacia \\
\hline & Fase III & Confirmación del medicamento: eficacia y seguridad \\
\hline & Fase IV & Seguimiento del medicamento comercializado \\
\hline \multirow{3}{*}{ Temporalidad } & Retrospectivo & $\begin{array}{l}\text { Estudio longitudinal, analiza en el presente datos del } \\
\text { pasado }\end{array}$ \\
\hline & Transversal & Estudio con datos obtenidos en un momento puntual \\
\hline & Prospectivo & $\begin{array}{l}\text { Estudio longitudinal. Los datos se obtienen en el } \\
\text { presente pero se analizaran en el futuro }\end{array}$ \\
\hline \multirow{2}{*}{$\begin{array}{l}\text { Aspecto de la } \\
\text { intervención }\end{array}$} & Explicativos & $\begin{array}{l}\text { Muestra homogénea de características definidas } \\
\text { para valorar la eficacia de un tratamiento. Resultados } \\
\text { no generalizables. }\end{array}$ \\
\hline & Pragmáticos & $\begin{array}{l}\text { Número elevado pacientes con características más o } \\
\text { menos comunes para valorar la eficacia de un } \\
\text { tratamiento. Resultados generalizables. }\end{array}$ \\
\hline \multirow{6}{*}{ Objetivo } & Equivalencia Terapéutica & $\begin{array}{l}\text { Comprobar que el fármaco a estudio es igual de } \\
\text { eficaz que el establecido. }\end{array}$ \\
\hline & Búsqueda de dosis & Establecer la dosis más eficaz para el tratamiento. \\
\hline & Dosis-respuesta & $\begin{array}{l}\text { Establecer la relación dosis-respuesta del } \\
\text { medicamento a estudio. }\end{array}$ \\
\hline & Bioequivalencia & $\begin{array}{l}\text { Comparar biodisponibilidad de dos o más formulas } \\
\text { farmacéuticas de un mismo principio activo. }\end{array}$ \\
\hline & Biodisponibilidad & $\begin{array}{l}\text { Estudia la fracción de la dosis administrada que } \\
\text { alcanza la circulación sistémica. }\end{array}$ \\
\hline & Estudio piloto & $\begin{array}{l}\text { El que se realiza previamente para el conocer datos } \\
\text { que permitan diseñar un ensayo más amplio }\end{array}$ \\
\hline \multirow{2}{*}{ Control } & Controlado & $\begin{array}{l}\text { Se evalúa simultáneamente un grupo experimental y } \\
\text { un grupo control (placebo). } \\
\text { Control activo; otro tratamiento con eficacia probada }\end{array}$ \\
\hline & No controlado & $\begin{array}{l}\text { No hay grupo control. } \\
\text { Se comparan resultados con datos históricos } \\
\text { obtenidos previamente. }\end{array}$ \\
\hline \multirow{2}{*}{ Enmascaramiento } & No enmascarado o abierto & $\begin{array}{l}\text { Sujeto y médico conocen la asignación de } \\
\text { tratamiento }\end{array}$ \\
\hline & $\begin{array}{l}\text { Enmascarado o cerrado } \\
\text { (Ciego) }\end{array}$ & $\begin{array}{l}\text { Sujeto, médico o ambos desconocen la asignación } \\
\text { de tratamiento Ciego (simple, doble o triple) }\end{array}$ \\
\hline \multirow{2}{*}{ Exposición } & Paralelo & $\begin{array}{l}\text { Grupo control y experimental reciben el tratamiento } \\
\text { en periodos sucesivos determinados al azar. }\end{array}$ \\
\hline & Cruzado & $\begin{array}{l}\text { Grupo control y experimental reciben el tratamiento } \\
\text { al mismo tiempo }\end{array}$ \\
\hline \multirow[t]{2}{*}{ Aleatorización } & $\begin{array}{l}\text { Aleatorizado } \\
\text { (Randomizado) }\end{array}$ & $\begin{array}{l}\text { Casos controles y experimentales distribuidos al } \\
\text { azar. }\end{array}$ \\
\hline & No aleatorizado & Selección de casos sin azar. \\
\hline
\end{tabular}


Los EC fase I/II desarrollados con medicamentos de terapias avanzadas no pueden tener un tamaño muestral tan elevado como los desarrollados con medicamentos convencionales, ya que presentan mayor varibilidad al tratarse de medicamentos biológicos y además, cada producto está hecho a medida y es destinado a un solo paciente. Desde el punto de vista logístico es también más difícil de ajustar y, con frecuencia, por razones de seguridad es conveniente hacer series consecutivas, lo que dificulta el diseño del brazo control y la aleatoriedad.

- Fase III. Son ensayos terapéuticos confirmatorios, generalmente comparativos y aleatorizados, que pueden involucrar múltiples médicos y hospitales tratando cientos o incluso miles de pacientes. Aparte de verificar la eficacia del medicamento, se busca determinar manifestaciones de toxicidad previamente no detectadas. También se confirma que la eficacia no depende del médico aplicador o del centro donde se lleva a cabo el tratamiento. En esta fase se obtiene una mejor perspectiva de la relación entre seguridad y eficacia.

- Fase IV. Esta fase comienza una vez que el medicamento ha sido aprobado por las agencias reguladoras y comercializado. Consiste en un seguimiento para evaluar las formas de optimizar el uso del medicamento (aplicaciones no descritas previamente) y detectar toxicidades previamente insospechadas, así como evaluar la eficacia a largo plazo. Son estudios de farmacovigilancia

\subsection{PRINCIPALES AGENTES EN UN ENSAYO CLÍNICO}

Los agentes que participan en un EC se engloban en 6 funciones principales:

\section{- Promotor}

Es la persona física o jurídica que tiene interés en la realización del EC, firma la solicitud de autorización dirigida al CEIC y a la AEMPS y se responsabiliza del EC. El promotor puede ser un individuo, empresa, institución u organización que se responsabilice del inicio, gestión y/o financiación del EC. 


\section{- Investigador}

El investigador principal es la persona responsable de dirigir el EC y firma la solicitud junto con el promotor. Es la persona responsable del desarrollo del EC en el centro. Además del investigador principal pueden existir otros investigadores coordinadores o colaboradores.

\section{- CEIC}

El comité ético de investigación clínica es un organismo independiente constituido por profesionales sanitarios y miembros no sanitarios. Es el encargado de velar por la protección de los derechos, seguridad y bienestar de los sujetos que participen en un ensayo y de ofrecer garantía pública al respecto. Actúa mediante un dictamen sobre el protocolo del ensayo, la idoneidad de los investigadores y la adecuación de las instalaciones, así como los métodos y los documentos que vayan a utilizarse para informar a los sujetos del ensayo, con el fin de obtener su consentimiento informado. En el caso de los EC multicéntricos el CEIC encargado de emitir el dictamen se denomina CEIC de referencia.

\section{- Autoridades reguladoras}

Incluye a las autoridades que revisan los datos preclínicos y clínicos proporcionados y que determinan si los datos aportados con suficientes para permitir que un nuevo medicamento sea comercializado, y a las autoridades que realizan inspecciones o recogen información sobre la seguridad de los medicamentos en investigación. Los EC deben ser insertos en las bases de datos Eudra y Clinicaltrials.gov. Además de ser aprobados por las autoridades reguladoras antes de ser iniciados. En España las autoridades reguladoras son la Agencia Española de Medicamentos y Productos Sanitarios (AEMPS) y las Comunidades Autónomas (CCAA).

\section{- Monitor}

Es el profesional capacitado con la necesaria competencia clínica para realizar el seguimiento directo del ensayo (monitorización); es elegido por el promotor y sirve de vínculo entre este y el investigador principal. 
La monitorización es la supervisión del progreso de un EC, asegurándose que se está realizando, registrando y notificando de acuerdo al protocolo, los procedimientos normalizados de trabajo (PNT), BCP y regulación aplicable.

\section{- Sujeto del ensayo}

Es el individuo que tras dar su consentimiento informado participa en un ensayo clínico.

Además de los agentes implicados en el desarrollo del EC, podemos destacar la Organización de Investigación por Contrato (CRO), que es una persona física o jurídica contratada por el promotor para realizar funciones o deberes del promotor en relación con el EC. Entre sus funciones destacan:

- Elaboración del protocolo y material del estudio

- Organización de Reuniones de Investigadores

- Puesta en Marcha

- Contratos con los Centros

- Monitorización

- Asignación aleatoria del tratamiento del ensayo

- Gestión de la medicación del ensayo

- Análisis de Muestras de los Pacientes del Ensayo

- Farmacovigilancia

- Pagos a Investigadores/Centros

- Análisis estadísticos

- Publicación de resultados.

\subsection{ETAPAS DEL ENSAYO CLINICO}

\section{- Inicio}

Es la etapa de puesta en marcha del EC, incluyendo selección de investigadores y centros, preparación de la documentación necesaria y obtención de las aprobaciones. Esta fase concluye con una visita de inicio en el centro de investigación. 


\section{- Seguimiento}

Es la etapa de desarrollo del EC, se realiza la inclusión de los pacientes y las visitas del estudio según el protocolo. Esta fase puede incluir análisis de datos intermedios y enmiendas al protocolo según lo establecido por el promotor. El desarrollo de esta fase es controlado mediante visitas de monitorización.

\section{- Cierre}

Es la etapa de finalización del ensayo, incluye la recogida de todos los datos clínicos, cierre de la base de datos, análisis de los datos, visita de cierre al centro y presentación del informe final del estudio a las autoridades sanitarias e investigadores participantes.

\subsection{DOCUMENTACION DEL ENSAYO CLINICO}

Los documentos esenciales en un ensayo clínico son todos los documentos que individual y colectivamente permiten la evaluación de la realización del estudio y la calidad de los datos producidos (ICH BPC, 1.28).

Estos documentos sirven para (ICH BPC, 8):

- Demostrar el cumplimiento del investigador, promotor y monitor con las normas BPC y los requisitos regulatorios aplicables.

- Asegurar un manejo adecuado del ensayo.

- Estos son los documentos auditados e inspeccionados por las autoridades reguladoras como parte del proceso para confirmar la validad de la ejecución del ensayo y la integridad de los datos recogidos.

Los documentos esenciales de un EC se pueden agrupar en tres secciones en función de la etapa del ensayo en la que se genera:

\section{- Antes de comenzar la fase clínica del ensayo}

- Manual del Investigador. Es un documento que engloba los datos clínicos y no clínicos sobre el medicamento en investigación. Tiene como objetivo proporcionar información para facilitar la comprensión y el cumplimiento del 
protocolo (dosis, frecuencia/intervalo de dosificación, métodos de administración, monitorización de seguridad). El manual proporciona información para apoyar el manejo clínico de los sujetos; debe ser revisado y actualizado anualmente siempre que exista nueva información. En el caso de un medicamento comercializado, se puede sustituir por la Ficha Técnica del producto. (ICH BPC, 1.45; RD 223/2004 art 2j).

- Protocolo del Ensayo Clínico. Es un documento donde se describen los objetivos, el diseño, la metodología, las consideraciones estadísticas y la organización de un ensayo. El término protocolo se refiere al protocolo original, a sus sucesivas versiones y a sus modificaciones.

- Enmiendas al Protocolo. Es una descripción escrita de un cambio o aclaración formar de un protocolo. (RD 223/2004 art 2k; ICH BPC, 1.44)

- Cuaderno de Recogida de Datos (CRD). Es un documento impreso, óptico o electrónico que recoge toda la información de cada sujeto del ensayo requerida por el protocolo para ser comunicada al promotor. ( ICH BPC, 1.22)

- Hoja de Información al Paciente. Es un documento impreso que incluye toda la información sobre la naturaleza, importancia, implicaciones y riesgos del EC. Se entrega al sujeto del ensayo para completar la información y explicación recibida por parte del investigador. (ICH BCP, 4.8.10)

- Consentimiento informado. Es un documento donde figura por escrito, firmada y fechada, la decisión adoptada de forma voluntaria por un sujeto de participar en un EC después de recibir toda la información acerca de la naturaleza, importancia, implicaciones y riesgos de participar en dicho ensayo.

- Otros documentos: en este punto se engloban diversos documentos que deben de acompañar a los anteriores:

- Aspectos financieros del ensayo.

- Certificado de Póliza de seguro.

- Acuerdos firmados entre las diferentes partes: Investigador/ Centro/Promotor/CRO

- Composición del CEIC que evaluó el estudio junto con su autorización. 
- Autorización del protocolo por la AEMPS

- Curriculum Vitae de todo el personal implicado en el estudio.

- Valores/Rangos normales de los procedimientos médicos, de laboratorio, técnicos o pruebas que se vaya a realizar durante el ensayo.

- Certificación o Valoración externa de Calidad u otro tipo de validación.

- Procedimiento de codificación en el caso de ensayos enmascarados.

- Informe de monitorización de la visita de inicio.

- Instrucciones para el manejo de los medicamentos en investigación y materiales relacionados con el ensayo, cuando no se incluyan en el manual del investigador o protocolo.

- Documentación adicional requerida por la Regulación Española:

- Compromiso del Investigador Principal y colaboradores

- Idoneidad de las Instalaciones y del equipo investigador

- Conformidad de otros servicios implicados.

\section{- Durante el desarrollo Clínico del ensayo}

- Actualizaciones de los documentos anteriores.

- Opinión favorable del CEIC de las actualizaciones presentadas

- Notificaciones de Enmiendas al protocolo y otros documentos a la AEMPS.

- Notificación del comienzo del ensayo a la AEMPS y CEICs.

- Informes de visitas de monitorización.

- Comunicaciones relevantes distintas a las visitas al centro, como cartas, notas de reuniones, notas de llamadas, ....

- Documentación relacionada con los sujetos participantes:

- Consentimientos informados firmados y fechados.

- Registro de los sujetos reclutados

- Lista de códigos de identificación de sujetos

- Documentos fuente: historias clínicas, datos de laboratorio, registros de dispensación en farmacia, radiografías,....

- CRD 
- Información de seguridad:

- Notificación de acontecimientos adversos graves al promotor

- Notificación de reacciones adversas graves e inesperadas AEMPS y CEICs, según proceda.

- Notificación de informes periódicos de seguridad a AEMPS y CEICs, según proceda.

- Hoja de firmas del estudio incluyendo el personal del centro involucrado en el ensayo y las funciones asignadas.

- Contabilidad del producto en investigación a nivel de sujeto y centro.

- Después de finalizar el ensayo.

- Documentos del ensayo que una vez concluido deben archivarse completados, firmados y fechados.

- Notificación de Finalización del ensayo a AEMPS y CEICs.

- Informe de la visita de cierra.

- Contabilización de los medicamentos de investigación en el centro

- Lista completa de los códigos de identificación de los sujetos

- Informe del EC. Según el RD, el promotor remitirá en el plazo de un año desde final del ensayo un informe final sobre los resultados obtenidos a la AEMPS y CEICs. 

HIPÓTESIS Y OBJETIVOS 



\section{HIPÓTESIS}

La hipótesis de trabajo en la que se basa esta Tesis es que un bioimplante generado por técnicas de ingeniería tisular, formado por la combinación de nuestra matriz de suero entrecruzado y células mesenquimales autólogas, sumaría a las propiedades osteogénicas de las células madre la capacidad osteoinductiva y osteoconductiva de la matriz tridimensional, aumentando así su potencia terapéutica. Por otro lado, dado el origen autólogo, tanto de las células mesenquimales como de la matriz, es probable que las reacciones adversas sean mínimas. Por este motivo, el bioimplante estudiado aquí, podría ser un tratamiento eficaz para reparar pérdidas de tejido óseo.

\section{OBJETIVOS}

Se plantean las acciones preclínicas y clínicas necesarias para testar nuestra hipótesis de trabajo, culminando en el ensayo clínico del bioimplante. El ensayo clínico es la fase final del desarrollo de una estructura tridimensional para ingeniería tisular patentada en el 2008 por el Dr. Meana Infiesta (WO 2008/119855; la doctoranda es coautora de la patente) en el Centro Comunitario de Sangre y Tejidos de Asturias (CCST) y en el Centro de Investigaciones Energéticas, Medioambientales y Tecnológicas (CIEMAT) de Madrid. Nuestro trabajo continúa también los estudios preclínicos en rata iniciados por la Dra. Gallego López en la Universidad de Oviedo, y continuados en ratas y en ovejas por el equipo de Cirugía Maxilofacial del Dr. Luis Miguel Redondo del Hospital Universitario Río Hortega de Valladolid y desarrollados en la Universidad de Valladolid (UVa) con la participación del Instituto de Biología y Genética Molecular (IBGM) y el Parque Científico de la UVa.

Los objetivos que se plantean en este ensayo son:

$1^{\circ}$. Conseguir células madre mesenquimales autólogas (MSV-H) a partir de esquirlas de hueso mandibular bajo Normas de Correcta Fabricación (NCF) en la Unidad de Producción Celular (UPC) del IBGM de Valladolid. 
$2^{\circ}$. Desarrollar una matriz tridimensional con suero autólogo bajo NCF en la UPC del IBGM y combinarla con las células MSV-H para generar un bioimplante denominado "BIOMAX".

$3^{\circ}$. Proporcionar evidencia preclínica suficiente para apoyar la factibilidad y seguridad del uso de "BIOMAX" para el tratamiento de defectos óseos, así como indicios de eficacia promoviendo la reparación de la pérdida de tejido y reabsorbiéndose sin mayores complicaciones. La consecución de este objetivo justificaría la propuesta del ensayo clínico en humanos.

$4^{\circ}$ : Desarrollar un ensayo clínico encaminado a demostrar la factibilidad y seguridad del producto "BIOMAX" aplicado a modo de injerto en defectos óseos de los maxilares como tratamiento de cavidades quísticas. Se comprobara si es realizable cada uno de los procedimientos establecidos en el protocolo y se registrarán los posibles efectos adversos relacionados con la terapia celular surgidos durante el periodo del ensayo clínico para estudiar la seguridad del procedimiento. Eventualmente, se valorarán los indicios de eficacia, especialmente en lo que se refiere a la producción de hueso objetivada por técnicas de imagen radiológica.

\section{PLANTEAMIENTO DEL ENSAYO CLíNICO}

El ensayo clínico culmina el desarrollo de este proyecto. Se plantea un ensayo abierto, intervencionista, fase I-II con 10 pacientes que presentan una patología frecuente y de difícil solución por terapias convencionales, como son los quistes óseos en la región máxilofacial.

Las células mesenquimales autólogas se aíslan a partir de una muestra obtenida del hueso esponjoso de la tuberosidad mandibular vía intraoral, y tras su expansión, son vehiculadas a la matriz tridimensional realizada a partir de suero también autólogo; la combinación de células y matriz genera el producto final "BIOMAX".

El proceso de fabricación, bajo condiciones GMP y autorizado por la AEMPS, tiene una duración total de 6-8 semanas en la UPC del IBGM. Una vez generado el producto final "BIOMAX", se envía al hospital donde se practica la ostectomía y enucleación del quiste bajo anestesia loco-regional y se rellena la cavidad residual con el bioimplante. 
Una vez realizado el injerto se realizan controles clínicos a las 2 semanas, 3 y 6 meses, que se acompañan de sofisticadas pruebas de imagen (ortopantomografía y tomografía computarizada) para seguir la evolución de la cavidad ósea en regeneración. El análisis de estos resultados permitirá valorar la factibilidad, seguridad e indicios de eficacia de la intervención.

Las distintas etapas de la intervención se resumen en el diagrama de flujo adjunto.

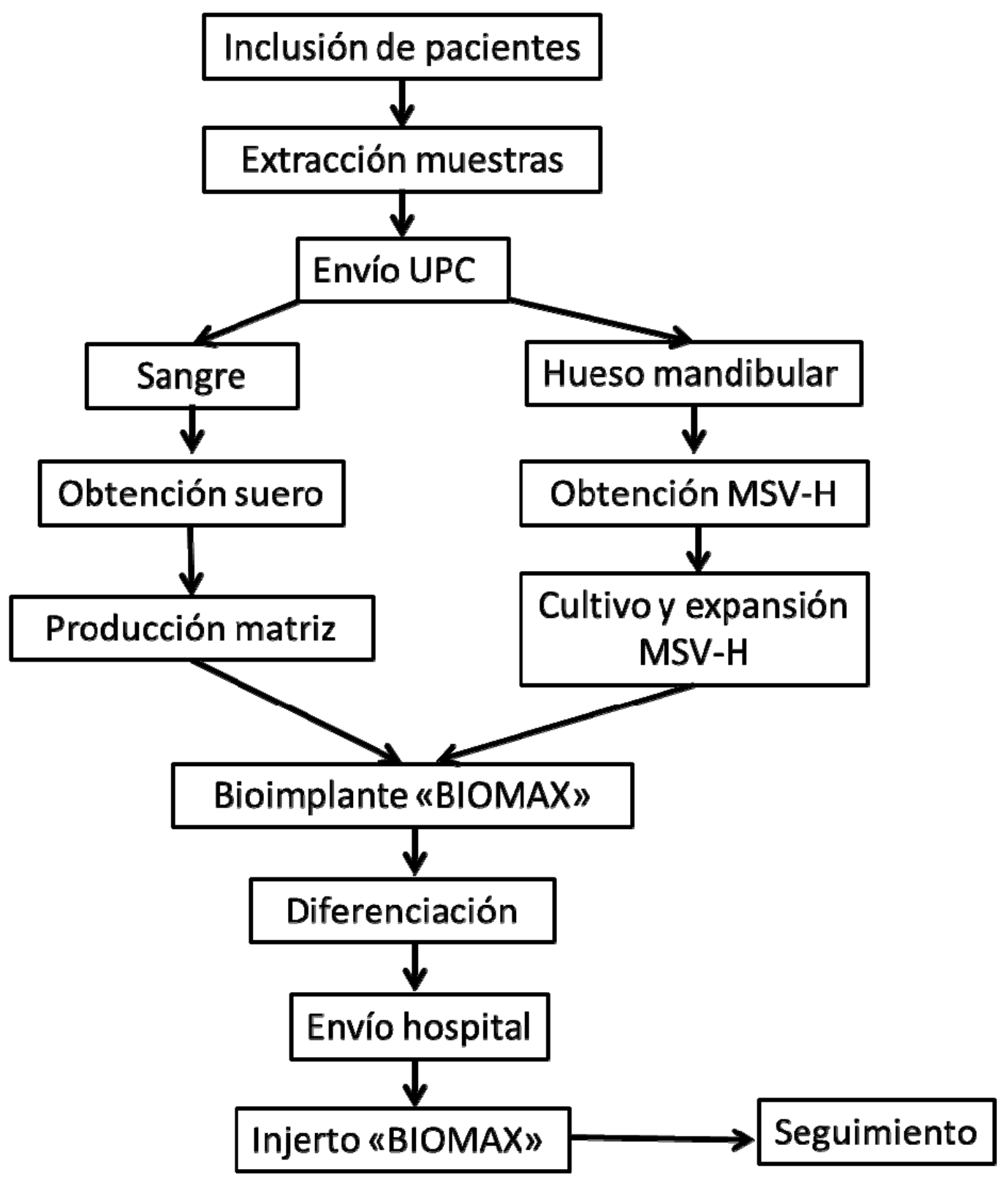



MATERIAL Y METODOS 



\section{ESTUDIOS “in Vitro”}

\subsection{Cultivos de hueso mandibular}

Las muestras de hueso esponjoso se obtuvieron en el quirófano ambulatorio del servicio de Cirugía Oral y Maxilofacial del Hospital Universitario Central de Asturias (HUCA) y del Hospital Universitario Río Hortega de Valladolid (HURH). Los pacientes firmaron un consentimiento para la utilización del material óseo extraído en estudios de regeneración ósea en animales de experimentación. La obtención de las muestras se realizó durante las ostectomías de los terceros molares o cordales sin acarrear mayor morbilidad a los pacientes. Las intervenciones quirúrgicas se realizaron en condiciones de asepsia y bajo anestesia local con una mezcla de articaína o mepivacaína con epinefrina al 2\% (Inibsa, España), realizándose una anestesia troncular de los nervios alveolar inferior y bucal.

Los pequeños fragmentos de hueso $(1-2 \mathrm{~mm})$ que se obtuvieron se trasladaron a los laboratorios de investigación del Centro Comunitario de Sangre y Tejidos (CCST) de Asturias o del Instituto de Biología y Genética Molecular (IBGM) de Valladolid, para su procesamiento.

Las muestras obtenidas en el HUCA se trasladaron en un recipiente estéril en suero fisiológico 0,9\% a temperatura ambiente, y las muestras extraídas en el HURH se trasladaron en medio de recogida a $4^{\circ} \mathrm{C}$. El medio de recogida se compone de RPMI 1640 con 25 mM HEPES y con L-glutamina (Lonza) suplementado con una combinación de antibióticos y antimicóticos (Gibco): penicilina $100 \mathrm{U} / \mathrm{ml}$, estreptomicina $100 \mu \mathrm{g} / \mathrm{ml}$, anfotericina A $0.25 \mu \mathrm{g} / \mathrm{ml}$.

El procesamiento de la muestra se realizó en varios pasos:

1. Se extrajo la muestra del recipiente estéril y se colocó en una batea estéril con ayuda de una pinza estéril.

2. Fraccionamos la muestra con un bisturí estéril y obtenemos pequeños fragmentos $(0,3-0,5 \mathrm{~mm})$ de hueso esponjoso que denominamos explantes.

3. Los explantes se lavaron con $15-20 \mathrm{ml}$ de solución enzimática de tripsina/EDTA (Gibco) durante 20 min para limpiar todos los restos sanguíneos. 
4. Centrifugamos la suspensión enzimática de tripsina y explantes a 1400 rpm durante $10 \min$ a $22^{\circ} \mathrm{C}$.

5. Eliminamos la tripsina del sobrenadante y añadimos $5 \mathrm{ml}$ medio de cultivo (DMEM con 4,5 g/L de glucosa (Gibco), 10\% FBS (Gibco) y 1\% Penicilina/Estreptomicina (1\% P/E; Biochrom AG, $10000 \mathrm{U} / 10000 \mu \mathrm{g} / \mathrm{ml}$ )) a los explantes que se encuentran en el sedimento de la centrifugación y los sembramos en un frasco de $25 \mathrm{~cm}^{2}$ mantenido a $37^{\circ} \mathrm{C}$ y con $5 \% \mathrm{CO}_{2}$.

El medio de cultivo se cambió dos veces por semana, retirándolo en su totalidad y añadiendo medio nuevo (DMEM+10\% FBS+ 1\% P/E).

Cada vez que se realizó el cambio de medio se comprobó el aspecto de la capa, la morfología celular y el porcentaje de crecimiento celular, mediante microscopio invertido de contraste de fases.

Cuando este frasco presentó un porcentaje de crecimiento entre el 80 y $90 \%$ se procedió a la tripsinización y expansión celular. En aproximadamente 10 días teníamos el cultivo primario confluente y procedíamos a la expansión del cultivo secundario (Figura 11) o criopreservación de las células (Figura 12).

Para la expansión celular, realizamos los siguientes pasos:

1. Retiramos el sobrenadante de medio de cultivo del frasco.

2. Añadimos $4 \mathrm{ml}$ tripsina/EDTA, incubamos $5-10 \mathrm{~min}$ a $37^{\circ} \mathrm{C}$ y comprobamos que las células se han despegado completamente del frasco.

3. Recogemos la suspensión celular a un tubo estéril (Falcon) con ayuda de una pipeta Pasteur, e inactivamos la tripsina con la misma cantidad (4 ml) de medio de cultivo al $10 \%$ de FBS.

4. Lavamos el frasco con $5 \mathrm{ml}$ de medio de cultivo y lo añadimos al tubo Falcon que contiene las células en suspensión.

5. Centrifugamos $10 \mathrm{~min}$ a $1400 \mathrm{rpm}$ y $22^{\circ} \mathrm{C}$.

6. Retiramos el sobrenadante y resuspendemos el sedimento celular en $5 \mathrm{ml}$ de medio de cultivo. 
7. Tomamos una muestra de $20 \mu \mathrm{l}$ para realizar los ensayos de contaje y viabilidad celular mediante Trypan-Blue (Biochrom, A.G) y una cámara de Neubauer.

Para realizar los ensayos de contaje y viabilidad diluimos la muestra celular con 20 $\mu l$. de Trypan-Blue (dilución 1/2), lo que nos permite diferenciar las células muertas o dañadas de las células vivas, ya que estas se tiñen de color azul, y así calculamos el porcentaje de viabilidad.

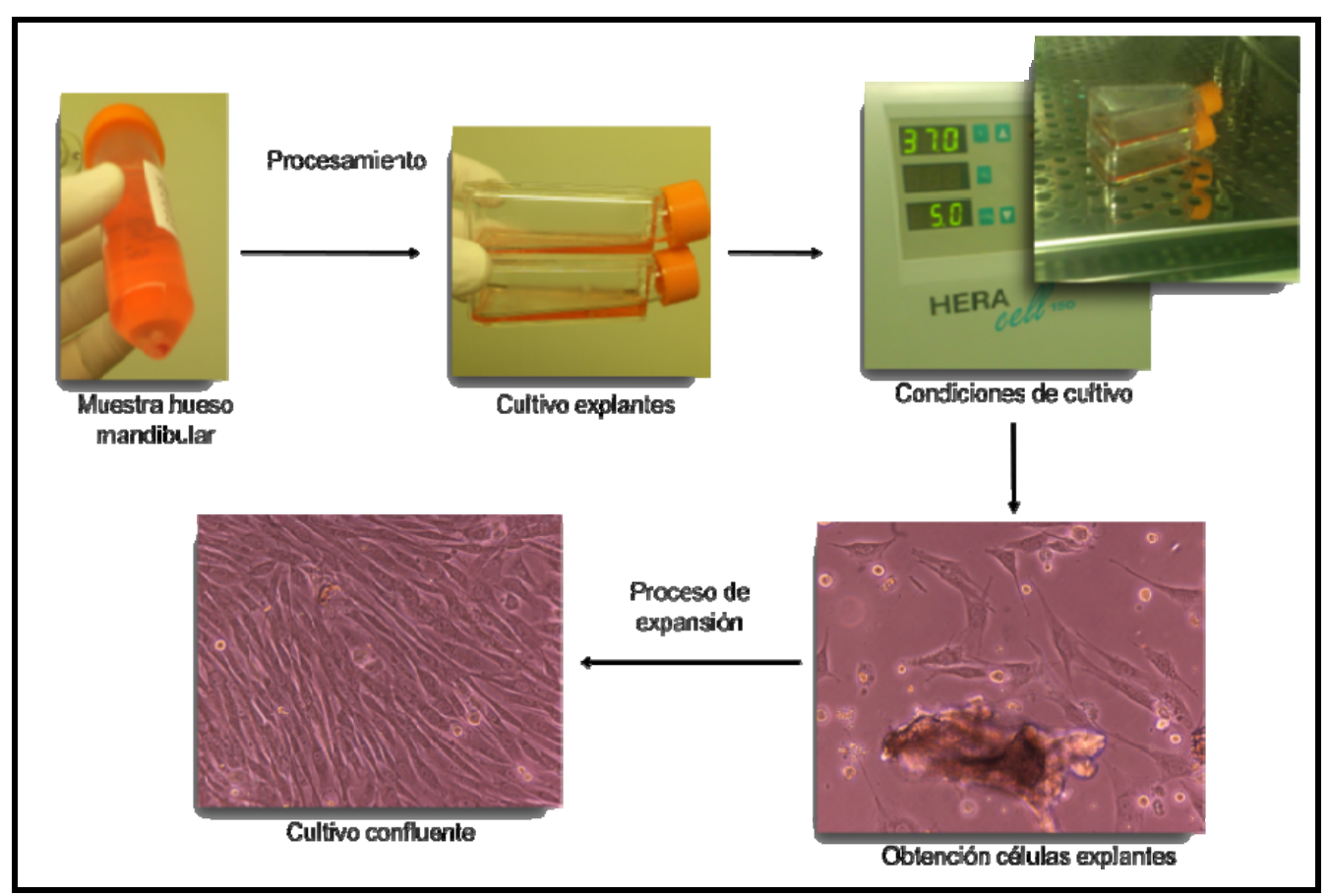

Figura 11: Protocolo de obtención de células mesenquimales de hueso y proceso de exapansión.

Montamos la cámara de Neubauer, acercamos la punta de la pipeta al borde del cubre y bajamos el émbolo de la misma lentamente, de este modo se llena el retículo de la cámara por capilaridad. Contamos los 4 cuadrantes de 16 cuadrados y calculamos el $\mathrm{n}^{\circ}$ medio de células por cuadrante; lo que nos permite mediante la siguiente fórmula el cálculo del número de células por ml.

$\mathrm{N}^{\circ}$ medio de células por cuadrante $\times 10^{4} \times 2=\mathrm{N}^{\circ}$ de células por $\mathrm{ml}$. 
Una vez que conocemos el $\mathrm{n}^{\circ}$ de células y la viabilidad de las mismas, procedemos a la expansión sembrando entre 5.000 y 15.000 células $/ \mathrm{cm}^{2}$ e incubando en las mismas condiciones que el cultivo primario: $5 \% \mathrm{CO}_{2}$ y $37^{\circ} \mathrm{C}$.

El cultivo secundario se mantuvo cambiando el medio cada tres días y se expandió hasta obtener el número de células necesario para sembrar en la matriz.

Las células obtenidas de los explantes se considera que están en pase 0 (P0), y cada vez que se realizó un proceso de expansión se añade un pase, es decir, a partir de las células P0 se obtiene células en pase 1 (P1), a partir de las células en $\mathrm{P} 1$, se obtienen células en pase $2(\mathrm{P} 2)$ y así sucesivamente.

Para la criopreservación celular seguimos los siguientes pasos:

1. Retiramos el sobrenadante de medio de cultivo del frasco.

2. Añadimos $4 \mathrm{ml}$ tripsina/EDTA, incubamos $5-10$ min a $37^{\circ} \mathrm{C}$ y comprobamos que las células se han despegado completamente del frasco.

3. Recogemos la suspensión celular a un tubo estéril (Falcon) con ayuda de una pipeta Pasteur, e inactivamos la tripsina con la misma cantidad (4 ml) de medio de cultivo al $10 \%$ de FBS.

4. Lavamos el frasco con $5 \mathrm{ml}$ de medio de cultivo y lo añadimos al tubo Falcon que contiene las células en suspensión.

5. Centrifugamos $10 \mathrm{~min}$ a $1400 \mathrm{rpm}$ y $22^{\circ} \mathrm{C}$.

6. Retiramos el sobrenadante y resuspendemos el sedimento celular en $5 \mathrm{ml}$ de medio de congelación (FBS y 10\% DMSO) e introducimos en el criovial.

7. El criovial se introduce a $-80^{\circ} \mathrm{C}$ durante 24 horas y posteriormente se mantiene en nitrógeno líquido $\left(-196^{\circ} \mathrm{C}\right)$ hasta su utilización.

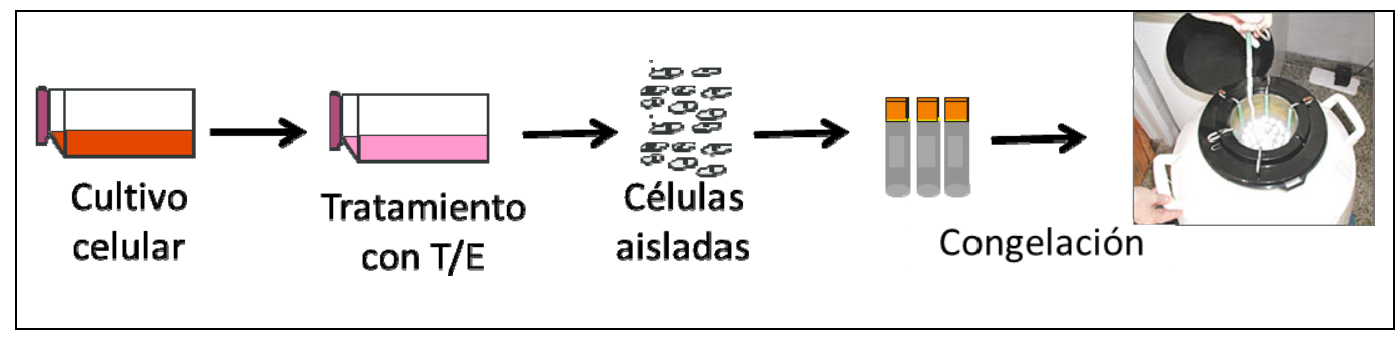

Figura 12. Protocolo de criopreservación celular. 
El proceso de criopreservación nos permite separar en el tiempo la fase obtención de las células de hueso y matriz, en el laboratorio, de la realización de los estudios "in Vivo".

La descongelación de las células para su expansión se realizó de forma rápida en el baño a $37^{\circ} \mathrm{C}$. Cuando el último cristal de hielo estaba a punto de fundirse, se resuspendieron las células en $5 \mathrm{ml}$ de medio de cultivo (DMEM, 10\% FBS y $1 \%$ $\mathrm{P} / \mathrm{E}$ ) y se centrifugaron a $1400 \mathrm{rpm}$ durante $10 \mathrm{~min}$. El pellet celular obtenido se resuspendió en medio nuevo, se realizaron ensayos de contaje y viabilidad celular, y las células se sembraron en frascos de cultivo a una densidad de 10.000 a 15.000 clas $/ \mathrm{cm}^{2}$, manteniendo el cultivo a $37^{\circ} \mathrm{C}$ y $5 \% \mathrm{CO}_{2}$. El medio de cultivo se cambió cada 3 ó 4 días y el proceso de expansión se realizó como se ha descrito anteriormente hasta obtener las células necesarias para sembrar la matriz.

\subsection{Fabricación de matriz tridimensional.}

La matriz tridimensional se forma por el entrecruzamiento de las proteínas del suero, principalmente la albúmina con un agente entrecruzante tipo aldehído, preferiblemente glutaraldehído.

El suero utilizado se obtuvo a partir de los donantes de sangre del CCST de Asturias. La matriz se realizó siguiendo el procedimiento descrito en la Patente WO2008 / 119855 desarrollada en el mismo centro.

La fabricación de matriz consiste en la mezcla del suero con el $5 \%$ de glutaraldehído (stock 25\%; concentración final: 1,25\%). Esta mezcla se congela a $80^{\circ} \mathrm{C}$ durante al menos 24 horas y tras un proceso de liofilización, hidratación y tallado se obtienen discos de matriz porosa, en este caso, de 4 ó $5 \mathrm{~mm}$ de diámetro y $2 \mathrm{~mm}$ de altura. (Ver más detalles proceso de fabricación en el punto 9). 


\subsection{Cultivo del bioimplante (matriz + células)}

Las células obtenidas a partir del hueso esponjoso mandibular se incluyen en la matriz tridimensional y se mantienen en cultivo a $5 \%$ de $\mathrm{CO}_{2}$ y $37^{\circ} \mathrm{C}$. El tiempo de cultivo varía según el estudio pudiendo ser de 1 a 30 días.

El medio de cultivo empleado ha sido diferente en función del estudio realizado; pudiendo utilizar:

- Medio de cultivo al $10 \%$ de FBS (DMEM $4,5 \mathrm{~g} / \mathrm{l}$ de glucosa, $10 \%$ FBS y $1 \% \mathrm{P} / \mathrm{E}$ ).

- Medio de diferenciación osteogénica (DMEM 4,5 g/l de glucosa, 10\% SBF, 1\% $\mathrm{P} / \mathrm{E}, 0.1 \mu \mathrm{M}$ Dexametasona (Sigma Aldrich), $50 \mu \mathrm{M}$ L-Ascorbato (Sigma Aldrich) y 10 mM ßGlicerofosfato (Sigma Aldrich).

\subsection{Estudios histológicos.}

Los bioimplantes fabricados "in Vitro" se fijaron formol al $10 \%$ y se incluyeron en parafina para realizar estudios histológicos.

\section{- Tinción Hematoxilina/Eosina(H/E)}

Las muestras se desparafinaron en xilol y se hidrataron en concentraciones decrecientes de alcohol (100-80-70-50 \%) hasta llegar a agua destilada. Posteriormente se procedió a la tinción con H/E realizando los siguientes pasos:

1. Inmersión en Hematoxilina de Harris durante 5 min

2. Lavar con agua corriente hasta que salga limpia.

3. Diferenciación con alcohol-ácido.

4. Lavar con agua corriente.

5. Inmersión en agua amoniacal.

6. Lavar con agua corriente (10-20 min)

7. Teñir con Eosina a temperatura ambiente 35 segundos.

8. Lavar con alcohol $95^{\circ}$ para eliminar la eosina.

9. Sumergir en alcohol $95^{\circ}$ durante $5 \mathrm{~min}$.

10. Sumergir en alcohol $100^{\circ}$ durante $10 \mathrm{~min}$.

11. Lavar con xilol de $10 \mathrm{~min}$.

12. Montar con Entellan (Merk) y observar al microscopio. 


\section{- Tinción de Von Kossa}

Las muestras se desparafinaron en xilol y se hidrataron en concentraciones decrecientes de alcohol (100-80-70-50 \%) hasta llegar a agua destilada antes de iniciar la tinción.

1. Tratar la muestra de 30 a 60 min con Nitrato de plata al $3 \%$ y con luz.

2. Realizar dos lavados de 5 min con agua destilada.

3. Lavar durante 5 min en Formol-carbonato de sodio.

4. Lavar durante $10 \mathrm{~min}$ en agua corriente.

5. Dejar la muestra 45 min con Ponceau de xilidina.

6. Lavar 1 segundo con ácido acético al $1 \%$.

7. Lavar 1 segundo con agua destilada.

8. Incubar 7 min con ácido fosfotúngstico-orange G.

9. Lavar 1 segundo con ácido acético al $1 \%$.

10. Lavar 1 segundo con agua destilada.

11. Deshidratar con soluciones crecientes de alcohol y finalmente con Xilol.

12. Montar con Entellan (Merk) para observar a microscopio.

\subsection{Estudios microscopía electrónica de barrido.}

Las muestras se fijaron con glutaraldehído $0.1 \mathrm{M}$ y tampón fosfato al 2\% (PBS, Gibco) durante 12 horas. Una vez fijadas, las muestras se deshidrataron en concentraciones crecientes de acetona 30-50-70-90-100\%. Posteriormente se secaron mediante la técnica del punto crítico de $\mathrm{CO}_{2}$ con el aparato Baltec CDP 030 Critical Point Dryer y se rociaron con una película de oro. Una vez preparadas las muestras se visualizaron con el microscopio electrónico de barrido JEOL JSM 6100 del Centro Cientifico-Tecnológico de la Universidad de Oviedo.

Las muestras observadas en la Unidad de Microscopia Avanzada del Parque Científico de la Uva, se fijaron en etanol y se visualizaron en el microscopio electrónico de barrido JEOL LEM-FS2200 HRP en el modo bajo vacío que utiliza vapor de agua como gas auxiliar. Este modo de imagen permite trabajar con muestras no conductivas sin ninguna preparación específica o recubrimientos metálicos. 


\section{ESTUDIOS “in Vivo”.}

Los estudios "in Vivo" se realizaron en el animalario de la Facultad de Medicina de la Universidad de Oviedo y de la Universidad de Valladolid. En todos los casos se han utilizado animales atímicos (ratas $r n u / r n u$ y ratones $n u / n u$ ) con matrices y células de origen humano; y se han realizado injertos heterotópicos y ortotópicos. En ambos casos, la manipulación de los animales se realizó siguiendo las pautas establecidas en cada animalario.

Las manipulaciones experimentales, el alojamiento y cuidado de los animales se realizaron en salas acondicionadas para asegurar la esterilidad de todo el procedimiento y seguimiento (racks ventilados para alojar los animales, cabina de flujo laminar vertical para las manipulaciones y dieta estéril).

Una vez finalizados los estudios, el sacrificio de los animales se realizó mediante inhalación de monóxido de carbono en cámara de eutanasia. Este método es considerado como aceptable por el Comité de Ética así como por varias asociaciones relacionadas con el bienestar de los animales de laboratorio a nivel internacional (Close y col, 1996; Close y col 1997).

\subsection{Injertos heterotópicos.}

Los injertos heterotópicos se caracterizan por estar en zonas anatómicamente anormales respecto al tejido que queremos reparar. En este caso, se han realizado injertos en el dorso de los ratones y en la zona inguinal en las ratas atímicas, para ver el comportamiento del bioimplante generado en un ambiente no condicionado para la regeneración ósea.

Los injertos en el dorso del ratón se colocaron tras una incisión de $1 \mathrm{~cm}$ en el dorso del animal anastesiado (inyección intraperitoneal de pentobarbital sódico (38 mg/kg de peso) y xilacina (75 mg/kg de peso), en un "bolsillo" generado por disección suprafascial con unas tijeras. Una vez colocado el bioimplante a estudio se suturó la incisión con Vicryl ${ }^{\circledR} 4 / 0$ (Ethicon). Los animales se sacrificaron a los 75 y 150 días del injerto. 
Los injertos inguinales se realizaron en ratas anastesiadas con xilocaína (10 mg/kg de peso) y ketamina (75 mg/kg de peso). Se generó un "bolsillo" por disección suprafascial entre el músculo recto y la arteria femoral, tras una incisión inguinal de $2 \mathrm{~cm}$. Una vez colocado el bioimplante a estudio se suturó la incisión con Vicryl® 4/0 (Ethicon). Los animales se sacrificaron a los 90 días del injerto.

\subsection{Injertos ortotópicos.}

Los injertos ortotópicos se caracterizan por realizarse en zonas anatómicamente idénticas, por lo que en esta ocasión, los trasplantes se han realizado en una lesión crítica mandibular, ya que evaluamos la regeneración ósea tras la aplicación del bioimplante como material de relleno.

Los estudios realizados en la Universidad de Oviedo evaluaron defectos críticos bicorticales de $5 \mathrm{~mm}$ de diámetro en la rama mandibular de ratas inmunocompetentes sacrificadas a los 35,56 y 77 días del injerto.

Los estudios realizados en la Universidad de Valladolid evaluaron defectos críticos bicorticales de $4 \mathrm{~mm}$ de diámetro (defecto óseo crítico para mandíbula de rata definido en los trabajos de Kaban y col, 1979 y 1981) en la rama mandibular de ratas atímicas sacrificadas a los 90 días.

En ambos casos, se realizó una incisión submandibular central de aproximadamente $1,5 \mathrm{~cm}$ de longitud, y se levantaron colgajos bilaterales de piel, músculo y periostio para acceder a ambos lados de la mandíbula. El defecto crítico se generó con una fresa de acero circular montada en un motor eléctrico estéril con irrigación con suero salino para impedir necrosis por liberación térmica. Una vez generado el defecto, se colocó el bioimplante a estudio correspondiente.

El cierre quirúrgico se realizó en dos planos, muscular y cutáneo, utilizando en una sutura de $\mathrm{Vicry}\left[\circledR\right.$ de $4 / 0$ en el primero y de $\mathrm{Vicryl}{ }^{\circledR}$ de $3 / 0$ en el segundo. 


\subsubsection{Estudio Radiológico.}

Las muestras fueron estudiadas mediante Tomografía Computarizada (TC) utilizando un TC Toshiba Aquilion 16 (Toshiba Medical Systems Corporation, Japón) en el HUCA o un TC multicorte (Siemens ${ }^{\circledR}$, Munich, Alemania) en el HURH. Las imágenes digitalizadas se analizaron mediante el programa de análisis de imagen Leica Qwin Pro (Leica Microsystem Imaging Solutions Ltd, Reino Unido) en el Centro Científico-Tecnológico de la Universidad de Oviedo; o con el software de procesamiento de imagen Osirix®, con la versión 3.7.1 de 32 bits. En ambos casos, se realizó la reconstrucción tridimensional de las mandíbulas que permitió evaluar la regeneración del defecto crítico generado.

\subsubsection{Estudios Histológicos.}

Los injertos heterotópicos realizados en el dorso de ratones atimicos se incluyeron en parafina una vez decalcificados con una solución de ácido etilenohidramintetraacético, y se sometieron a estudios inmunohistoquímicos con vimentina y osteocalcina humana. Por otro lado, los injertos ortotópicos realizados en la zona inguinal de ratas atímicas, se fijaron en Tissue Tec OCT (Sakura), se cortaron con el criotomo y se realizaron tinciones de hematoxilina/eosina y giemsa.

\section{- Estudio de Vimentina humana.}

La vimentina es una proteína que forma parte de los filamentos intermedios del citoesqueleto de las células, principalmente en células de origen mesenquimal y tejidos neoplásicos.

Los cortes de la muestras se desparafinaron $y$ se sometieron al desenmascaramiento antigénico en la olla a presión con tapón citrato $(0.1 \mathrm{M}, \mathrm{pH}$ 6.0) y EDTA $(0.001 \mathrm{M}, \mathrm{pH} 8) 10$ minutos.

La tinción inmunohistoquímica se realizó con el siguiente protocolo: 
1. Incubo durante 15 min en cámara húmeda a temperatura ambiente con solución Peroxidasa Bloking (tampón fosfato con peróxido de hidrógeno, 15 $\mathrm{mmol} / \mathrm{l}$ de $\mathrm{NaN}_{3}$ y detergente. Dako. S2023), para inhibir la actividad de la peroxidasa endógena de la muestra.

2. Realizar 3 lavados de 5 min con PBS-Tween al 0,05\%.

3. Incubar en BSA $1 \%$ en PBS durante 30 min. (como mínimo) para inhibir las uniones inespecíficas.

4. Incubar durante 1 hora con el anticuerpo primario a una concentración 1:100 en cámara húmeda y temperatura ambiente.

5. Realizar 3 lavados de 5 min con PBS-Tween $0,05 \%$.

6. Incubar 20 min con vimentina a una concentración 1:50 en cámara húmeda y temperatura ambiente.

7. Realizar 3 lavados de 5 min con PBS-Tween $0,05 \%$.

8. Revelar con DAB (Kit Dako, K3468), un sistema de alta sensibilidad para los métodos de tinción inmunohistoquímica basados en peroxidasa y de hibridación in situ. Tras la oxidación, la DAB forma un producto final de color marrón en el punto del antígeno diana. Mantener en la solución de DAB hasta que la muestra se coloree.

9. Neutralizar con agua destilada

10. Contrateñir con hematoxilina $25 \%$ durante 1 minuto.

11. Montar con Entellan (Merk) para su observación al microscopio.

\section{- Estudio de Osteocalcina humana.}

La osteocalcina es una proteína que se encuentra en la matriz extracelular de los huesos y de la dentina y participa en la regulación de la mineralización de huesos y dientes.

La determinación de esta proteína se realiza mediante un ELISA con el anticuerpo (OCT4-30) GTX13418 (Genetex, USA) según las instrucciones del fabricante. Estos estudios se realizaron en la Unidad de Metabolismo Óseo y Mineral del HUCA. 


\section{- Tinción Hematoxilina/Eosina.}

Se realizó como se describe en el punto 1.4 .

\section{- Tinción de Giemsa.}

La tinción de giemsa se realizó en muestras fijadas en Tissue Tec OTC y congeladas que se cortaron con el criotomo, por lo que no precisan hidratación. Las muestras se mantuvieron durante $10 \mathrm{~min}$ con la solución de giemsa y posteriormente se lavaron con abundante agua. Para su observación con el microscopio se deshidrataron con soluciones decrecientes de alcohol y se montaron con Entellan (Merk).

\section{DISEÑO DEL ENSAYO CLÍNICO}

El ensayo clínico desarrollado es un ensayo abierto y prospectivo, fase $\mathrm{I} / \mathrm{II}$ con número EUDRACT 2010-024246-30 y Código: BIOMAX-VA-2010. En el siguiente enlace http://www.generabiotec.com/ biomax/BIOMAX Protocolo\&Anexos.pdf puede consultarse el protocolo clínico completo (PEI). En síntesis, el ensayo pretende validar para uso clínico un producto de bioingeniería tisular compuesto por células MSV-H (células madre mesenquimales, fabricadas en el IBGM de Valladolid, que ya han sido aprobados por la Agencia Reguladora española (AEMPS) para tres ensayos clínicos anteriores) y una matriz de suero autólogo entrecruzado (patentada por el Banco de Sangre y Tejidos de Asturias Ref.: WO2008 / 119855) para el relleno de quistes maxilares. Estos dos grupos colaboran en este proyecto con el equipo de Cirugía Maxilofacial del Hospital Universitario Río Hortega, que dirige el ensayo clínico y se ocupa de los aspectos médicos.

El ensayo propuesto se basa en los resultados positivos obtenidos en estudios previos en animales realizados por el presente equipo multidisciplinario. Los investigadores, proponen un ensayo clínico de fase $1 / I 1$ con 10 pacientes que presentan quistes óseos en la región maxilo-facial. 
Las células madre mesenquimales autólogas son aisladas a partir de una muestra de hueso esponjoso mandibular (MSV-H), se siembran en la matriz de suero autólogo y se cultivan de 20 a 30 días con medio de diferenciación osteogenico, formando el bioimplante "Biomax". En este momento, se realiza la enucleación del quiste por cirugía y la cavidad se rellena con el bioimplante. Los chequeos post quirúrgicos se realizan a las 2 semanas, 3 y 6 meses, siguiéndose la evolución de la cavidad mediante ortopantomografia y tomografía computarizada.

El ensayo clínico se ha registrado en la base de datos del Instituto Nacional de Salud (National Institutes of Health- NIH) de Estados Unidos, con el identificador NCT01389661. (Figura 13).

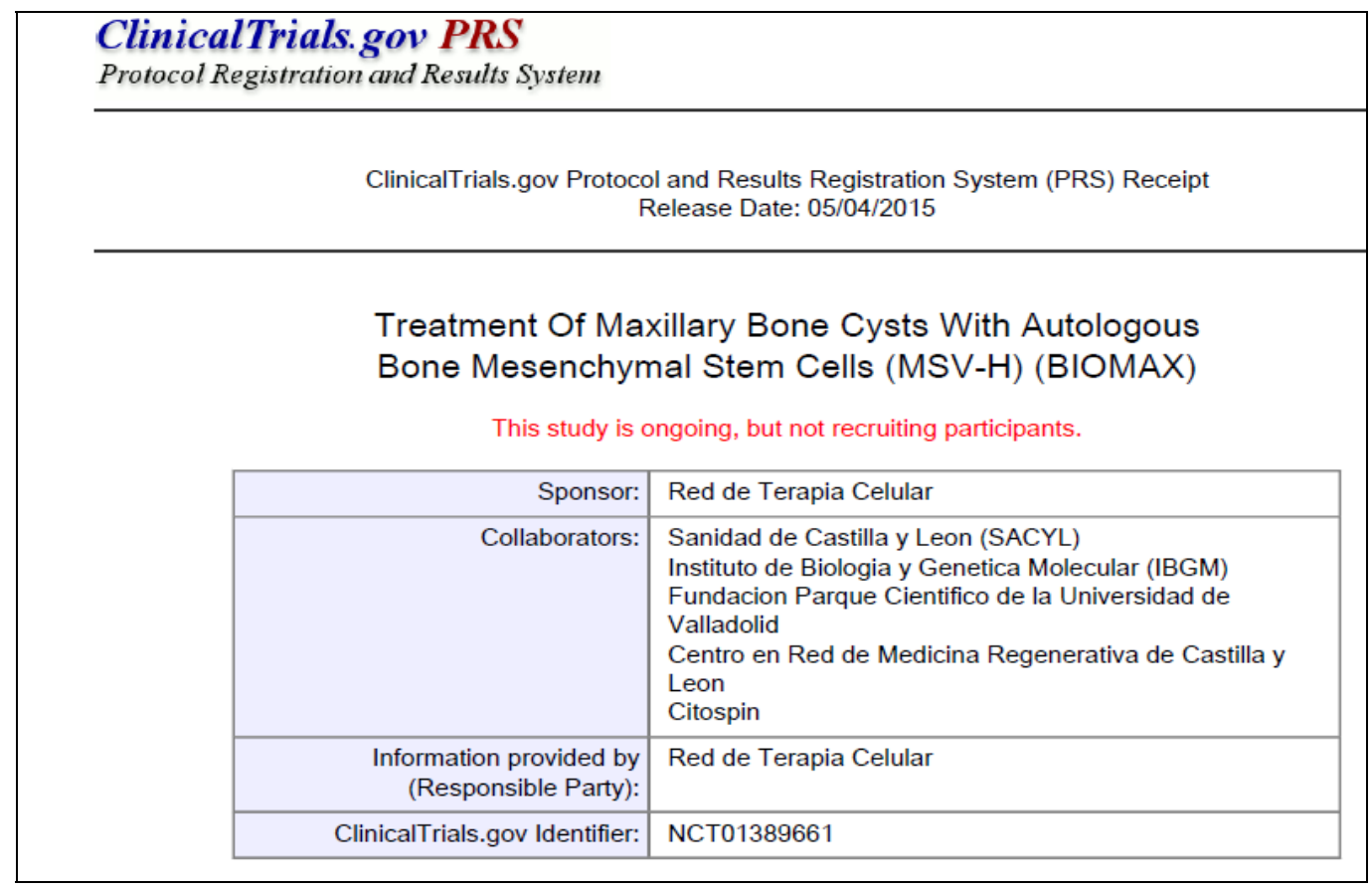

Figura 13. Reseña en el registro del NIH

El estudio incluye cinco visitas clínicas y dos intervenciones quirúrgicas como se puede ver en el calendario mostrado en la Tabla 4.

- V0: Visita inicial en la que se realiza el diagnóstico clínico. 
- V1: Visita de inclusión del paciente en el ensayo clínico y cumplimentación de la documentación necesaria. Incluye la explicación detallada de la hoja de información del paciente y la firma del consentimiento informado (http://www.generabiotec.com/ biomax/BIOMAX Protocolo\&Anexos.pdf )

- C1: Primera cirugía para la obtención de muestras de hueso esponjoso mandibular, extracción de sangre y realización de pruebas diagnósticas pretratamiento.

- C2: Segunda cirugía para realizar el tratamiento con el bioimplante.

- V2: Primera visita de seguimiento tras el tratamiento, se realiza a las dos semanas de la colocación del bioimplante.

- V3: Segunda visita de seguimiento a los dos meses de realizar el tratamiento.

- V4: Última visita de seguimiento a los seis meses de realizar el tratamiento.

Tabla 4. Calendario de desarrollo del EC.

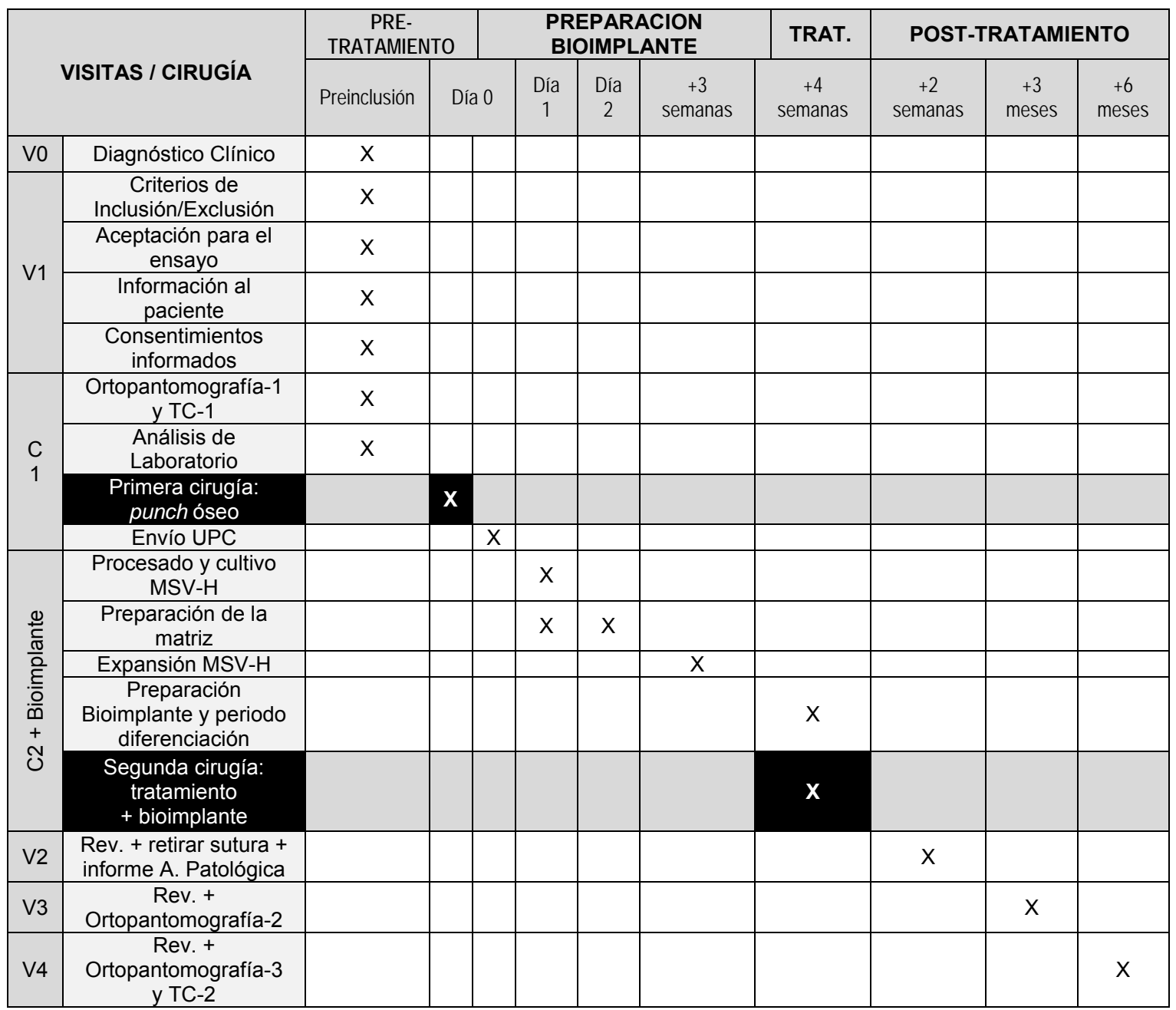




\section{INSTALACIONES Y EQUIPOS}

La fabricación del medicamento en fase de investigación bioimplante "BIOMAX" se ha realizado en la Unidad de Producción Celular (UPC) del IBGM de Valladolid, que cumple con todos los requisitos exigidos por la Directiva Europea 2003/94/EC del 8 de Octubre de 2003, por la que se establecen los principios y directrices de las prácticas correctas de fabricación de los medicamentos de uso humano y de los medicamentos en investigación de uso humano.

Las instalaciones de la UPC tienen autorización de la AEMPS desde Enero de 2007 para fabricar medicamentos de terapia celular para uso humano y a partir de entonces ha sido auditada de forma rutinaria, cada 3 años, siendo la última auditoria aprobada en mayo de 2013.

La fabricación de Biomax se llevó a cabo en la sección 1 de la UPC, que es una sala blanca de ambiente controlado formada por una sala se elaboración, una sala de envasado, un vestuario, un prevestuario, un distribuidor y una zona de acondicionamiento, como se puede ver en la Figura 14.

Una sala blanca es un área de ambiente controlado (partículas en el aire, temperatura, humedad, presiones, iluminación) con bajos niveles de contaminación. Este tipo de salas se caracteriza por tener paredes vinílicas con rincones redondeados para facilitar la limpieza y evitar acumulaciones de suciedad, tener esclusas que mantienen las diferencias de presión entre las salas y las aíslan del exterior; y además, utilizar filtros HEPA para mantener el aire libre de partículas. Los operarios que trabajan en las salas blancas deben utilizar una vestimenta especial, que evita la generación de partículas y la introducción de contaminantes en dicho área. Sin embargo, a pesar de sus características que permiten una fabricación aséptica, las salas blancas tienen una gran desventaja que es el alto coste de implementación y de mantenimiento.

La UPC del IBGM es una sala blanca de presión positiva. La presión del aire aumenta a medida que nos aproximamos a la sala de elaboración a través de las diferentes esclusas: prevestuario, vestuario y distribuidor; lo que evita la entrada de partículas en suspensión y microorganismos. 


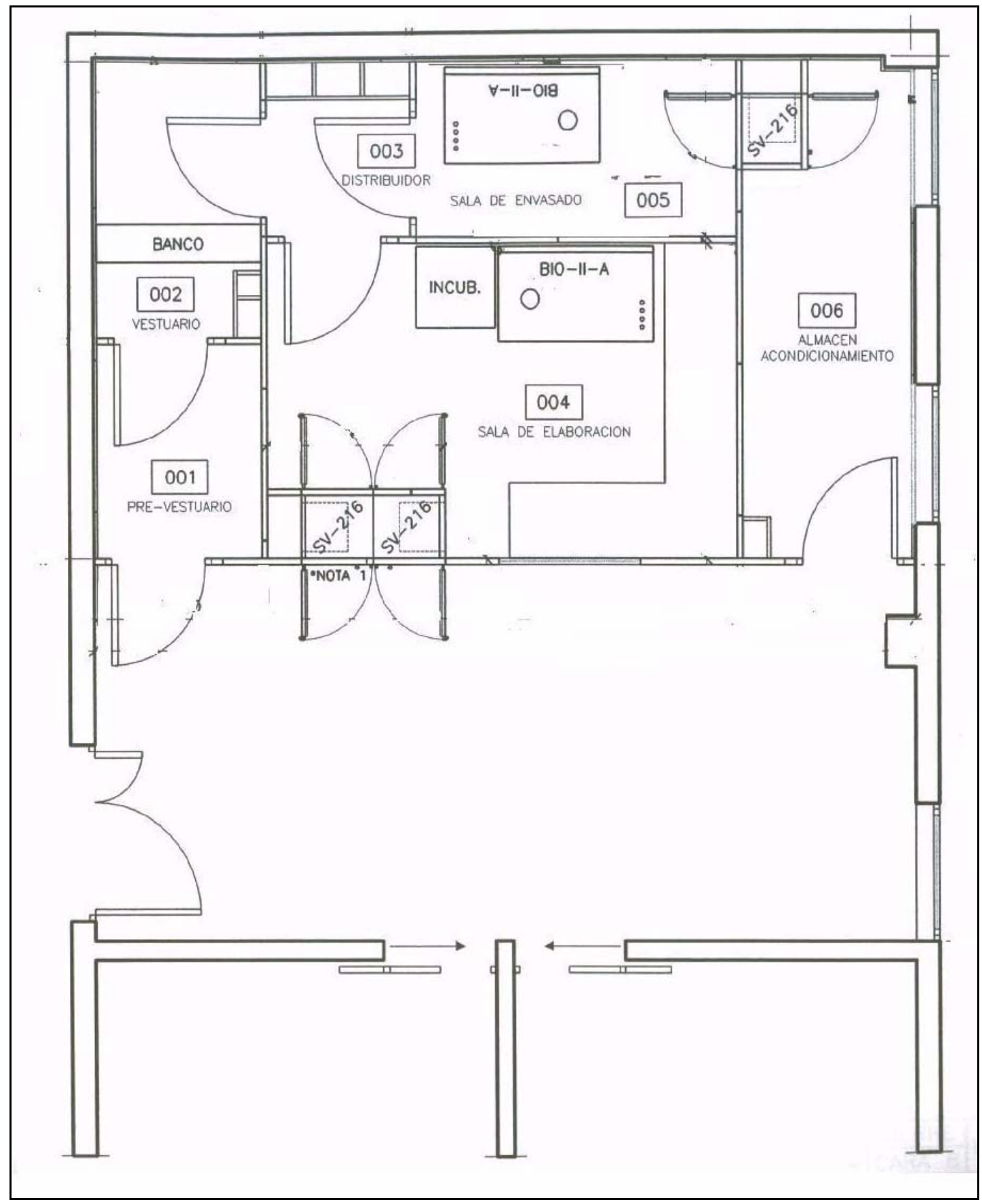

Figura 14. Plano instalaciones Sección 1 de la UPC. 
Los equipos utilizados en el proceso de fabricación del bioimplante BIOMAX son:

- Cabinas de seguridad microbiológica BIO-II-A y BIO-II-A/P.

- Centrífuga.

- Incubadores de $\mathrm{CO}_{2}$ con rutina de descontaminación.

- Microscopio de contraste de fases.

- Micropipetas de volúmenes ajustables.

- Frigorífico y Congelador.

- Cámara Frigorífica isotérmica.

- Autoclave.

- Liofilizador.

\section{SELECCIÓN DE PACIENTES}

Se seleccionaron 10 pacientes del Servicio de Cirugía Oral y Maxilofacial del Hospital Universitario Río Hortega (HURH) de Valladolid siguiendo los criterios de inclusión y exclusión enumerados en la Tabla 5.

Todos los pacientes han sido informados clara y cuidadosamente del procedimiento que se realiza, y de las expectativas y riesgos del tratamiento asegurándose de que el paciente lo entiende y lo acepta. Esta parte termina con la firma del consentimiento informado, para participar en el ensayo y del consentimiento informado quirúrgico. La hoja informativa del paciente se puede ver http://www.generabiotec.com/ biomax/BIOMAX Protocolo\&Anexos.pdf

Tabla 5. Criterios de inclusión y exclusión

\section{Criterios de inclusión:}

- Quiste óseo maxilar con un diámetro de 2-4 cm.

- Comprensión y aceptación de las condiciones de ensayo.

- Consentimiento informado por escrito del paciente para el ensayo y para la cirugía.

- En las mujeres, prueba de embarazo negativa al inicio del procedimiento.

- En las mujeres, el compromiso de utilizar métodos anticonceptivos durante el estudio. 
Criterios de exclusión:

- Edad menor de 18 años o mayor de 65 años.

- Incapacidad o dependencia legal.

- Embarazo, lactancia, o inscripción en programas de fertilidad.

- Procesos oncológicos anteriores o concomitantes.

- Serología positiva para el $\mathrm{VIH}-1$ o $\mathrm{VIH}-2$, hepatitis $\mathrm{B}(\mathrm{HBsAg}$, anti-HCV-Ac) o hepatitis C (anti-HCV-Ac).

- Pacientes inmunodeprimidos.

- Enfermedad sistémica con efectos potenciales sobre el metabolismo óseo.

- Malformación máxilofacial congénita o adquirida.

- Pacientes en tratamiento con fármacos que actúan sobre el metabolismo óseo, como los glucocorticoides y los bifosfonatos.

- Infección activa o reciente del quiste.

- Recidiva del quiste (cirugía previa).

- Participación en otros ensayos o estudios en los últimos 3 meses.

- Otras condiciones patológicas o circunstancias que dificulten la participación en el estudio según criterio médico.

\section{ESTUDIO RADIOLÓGICO.}

Los pacientes incluidos en el ensayo se someten a dos tipos de estudios radiológicos, la ortopantomografia y la tomografía computarizada.

\subsection{Ortopantomografía}

La ortopantomografia permite evaluar el defecto quístico y sus medidas bidimensionales, alto y ancho, determinando la densidad de la trama ósea de la zona afectada con respecto al hueso sano adyacente. La prueba se realiza con el ortopantomógrafo, asegurando el mismo grado de magnificación y Kilovoltaje del estudio (68 kV y $6 \mathrm{~mA}$ ). Asimismo se realiza el análisis y tratamiento de la imagen digitalizada, determinando en una escala de grises (o de falso color) la magnitud del proceso reparativo del hueso (Figura 15).

Las características del ortopantomógrado son:

- Planmeca proline XC

- Total filtration $2.5 \mathrm{~mm} \mathrm{Al}$

- SN XC 429703

- $80 \mathrm{Kv}$ maximum

- Producto Láser clase I 


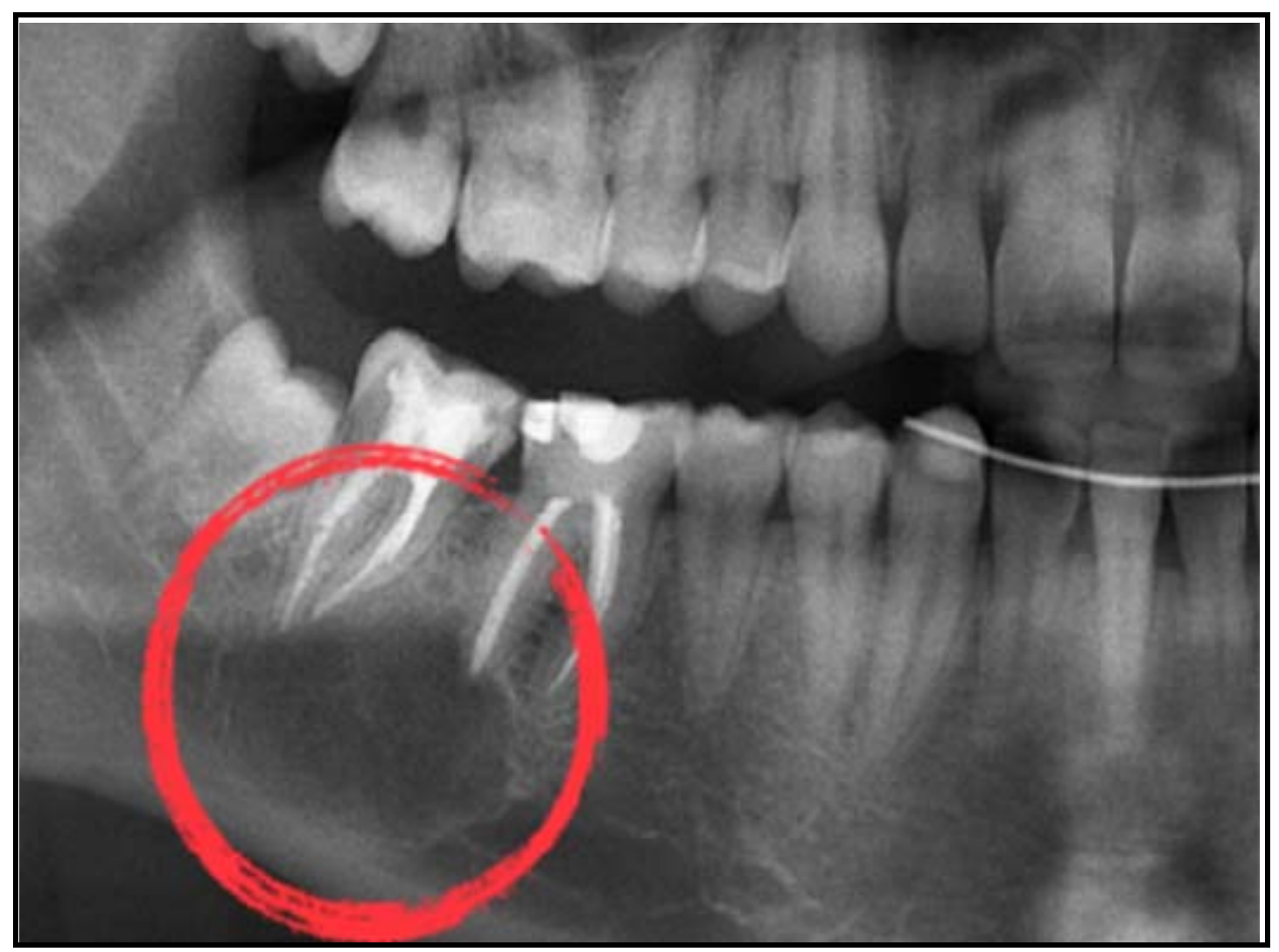

Figura 15: Detección del quiste por ortopantomografia

Al paciente se le realizan tres ortopantomografías,

- ORTO-1. En el momento del diagnóstico, para determinar el tamaño del defecto quístico a reparar.

- ORTO-2.A los tres meses de la intervención.

- ORTO-3: tras seis meses de la intervención

\subsection{Tomografía computerizada (TC)}

El estudio del quiste con tomografía computerizada (TC) permite la reconstrucción tridimensional de la cavidad. Estos estudios se realizan con un TC-multicorte de las siguientes características:

- TC multicorte Siemens Somatom Sensation 64 (64 cortes), configurado para macizo facial con cortes de $0.75 \mathrm{~mm}(64 \times 0.6 \mathrm{~mm}), 120 \mathrm{Kv}$, Pitch 0.9 .

- Tiempo de rotación: 1 segundo. 
- Incremento de reconstrucción: $0.4 \mathrm{~mm}$.

- Filtros de reconstrucción H21 homogéneo.

- Ventana de partes blandas.

- Segunda reconstrucción con filtros de 60 definido o 70 muy definido, con ventana ósea.

Las imágenes obtenidas en formato Dicom se exportan al sofware Osirix ${ }^{\circledR}$ (Versión 3.7.1 de 32 bits), plataforma de uso libre y sin coste, desarrollado para ordenadores de la casa Apple ${ }^{\circledR}$. El análisis de los ROI (regiones de interés) permite la reconstrucción y la medición volumétrica de la cavidad y del hueso regenerado tras el tratamiento.

El análisis simultáneo de cortes radiográficos axiales, sagitales y coronales permite la medición de áreas y en ellas determinar la densidad ósea en unidades Hounsfield.

Al paciente se le realizarán dos tomografías computerizadas, en el momento del diagnóstico y a los 6 meses de la intervención.

\section{MUESTRAS PARA ANÁLISIS}

Las muestras requeridas para la realización del ensayo se obtienen en el HURH de Valladolid.

El proceso que nos ocupa requiere dos tipos de muestras:

- $\underline{\text { Sangre: }}$ para la producción de la matriz tridimensional. Esta muestra (10-40 ml) se extrajo del paciente mediante una venopunción.

- Hueso esponjoso para la obtención de células mesenquimales de hueso. La muestra de hueso intraoral autólogo se obtiene mediante un aspirado de hueso esponjoso de la tuberosidad maxilar con una trefina de $2 \mathrm{~mm}$, bajo anestesia local y sedación del paciente; en el Servicio de Cirugía Oral y Maxilofacial del HURH de Valladolid. (Figura 16) 


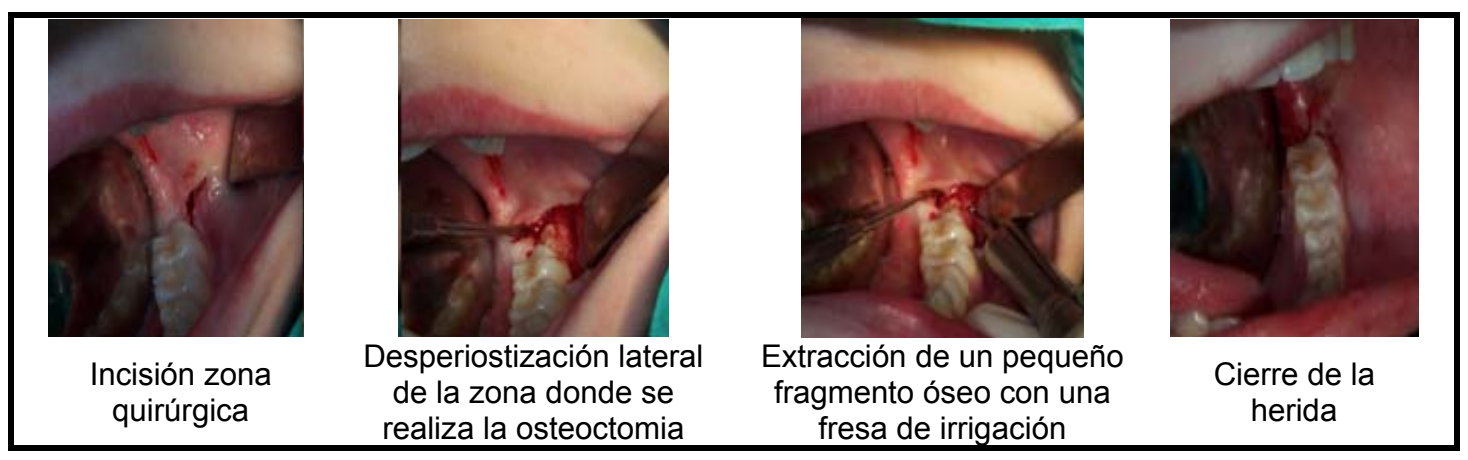

Figura 16: Obtención de la muestra de hueso mandibular

\section{OBTENCION DE CÉLULAS MESENQUIMALES DE HUESO}

La obtención de células mesenquimales de hueso (MSV-H) se realizó mediante el cultivo de explantes del aspirado de hueso esponjoso mandibular en la Unidad de Producción Celular (UPC) del IBGM de Valladolid. Las muestras de hueso esponjoso se extrajeron por personal especializado en condiciones asépticas, y se trasportaron hasta la UPC en un recipiente estéril, con medio de recogida de la siguiente composición: RPMI 1640 con 25 mM HEPES y con L-glutamina (Lonza), suplementado con una combinación de antibióticos y antimicóticos (Gibco): penicilina $100 \mathrm{U} / \mathrm{ml}$, estreptomicina $100 \mu \mathrm{g} / \mathrm{ml}$, anfotericina A $0.25 \mu \mathrm{g} / \mathrm{ml}$. Las muestras se mantuvieron a $4^{\circ} \mathrm{C}$ durante el transporte y hasta su procesamiento dentro de la UPC.

El procesamiento de la muestra se realizó siguiendo el protocolo descrito en el punto 1.1 e incorporando los controles necesarios para realizar el proceso conforme a las NCF.

En este punto, reservamos el medio de recogida para realizar análisis de Control de Calidad (Hemocultivo y Micoplasma), y comprobar si la muestra está contaminada previamente al procesamiento y además, se reservaron los dos primeros cambios de medio, un cambio de medio a la semana y el medio retirado previamente al tratamiento con tripsina para realizar los análisis de control de calidad (Hemocultivo y Micoplasma) y así evaluar la asepsia el proceso de expansión. 


\section{PRODUCCIÓN DE LA MATRIZ TRIDIMENDISIONAL}

Este proceso se realizó en la Sala de Liofilización de la UPC mediante el siguiente procedimiento (Figura 17):

\section{- Obtención de suero autólogo}

El suero autólogo se obtiene a partir de la muestra de sangre del paciente, que una vez coagulada se centrifugó durante 10 minutos a 3000 rpm, y se recuperó la fracción sérica, que se mantuvo a $-20^{\circ} \mathrm{C}$ hasta su utilización.

Se toma una muestra de $500 \mu \mathrm{l}$ de suero autólogo para análisis de Control de Calidad microbiológica.

\section{- Producción de la matriz tridimensional}

Descongelamos el suero a $4^{\circ} \mathrm{C}$ y mezclamos con el $5 \%$ de glutaraldehído (Sigma Aldrich; stock al 25\%, concentración final al 1.25\%) en un tubo Falcon. Aspiramos la mezcla con una jeringa de $20 \mathrm{ml}$ y colocamos un tapón Luer Lock. Dejamos coagular la mezcla durante un tiempo $\leq 10 \mathrm{~min}$. Identificamos el envase de la matriz tridimensional (jeringa), embolsamos la jeringa con doble bolsa de papel mixto para autoclave y congelamos a $-80^{\circ} \mathrm{C}$ durante 24 horas.

\section{- Liofilización}

La liofilización nos permite obtener una materia de amplia porosidad porque eliminamos la totalidad de la fracción acuosa de la matriz, y además eliminamos el agente entrecruzante no fijado a la proteína globular, que resultaría tóxico para las células.

Cortamos la punta de la jeringa que contiene la matriz congelada a $-80^{\circ} \mathrm{C}$ con un bisturí, sacamos la matriz lentamente con cuidado de no romperla y la introducimos en un tubo Falcon. Colocamos la matriz en una bandeja del liofilizador previamente enfriado a $-80^{\circ} \mathrm{C}$ y liofilizamos hasta la completa deshidratación de la matriz (aproximadamente $24 \mathrm{~h}$ ). 
Introducimos la matriz deshidratada lentamente en un tubo falcon y colocamos en un recipiente estéril para coger una pequeña muestra con ayuda de unas pinzas estériles, para análisis de control de calidad microbiológico (cultivo microorganismos aerobios y anaerobios).

\section{- Hidratación}

La matriz obtenida tras la liofilización es muy porosa, frágil y difícil de manipular, por lo que debe ser hidratada para que tenga resistencia y elasticidad. Esta fase se realizó con etanol en concentraciones decrecientes y a temperatura ambiente: introducimos la matriz en etanol absoluto durante al menos 24 horas; pasado este tiempo eliminamos el etanol absoluto y añadimos etanol $95^{\circ}$. Tras 24 horas; eliminamos el etanol $95^{\circ}$ y lavamos con etanol $80^{\circ}$ durante al menos 24 horas. Pasado este tiempo retiramos el etanol $80^{\circ}$ y añadimos etanol $70^{\circ}$ y dejamos 24 horas antes de tallar la matriz.

\section{- Tallado de la matriz}

La matriz obtenida tras el proceso de hidratación es un soporte poroso que puede ser cortado con facilidad sin rotura, y además permite el cultivo de células en su interior.

- Sacamos la matriz hidratada del frasco con una pinza estéril.

- Colocamos la matriz en una batea estéril y cortamos en discos de $2 \mathrm{~cm}$ de diámetro por $0,3 \mathrm{~cm}$ de grosor con ayuda de un bisturí estéril.

- Introducimos los discos obtenidos en un tubo Falcon con Etanol $70^{\circ}$ y así los conservamos a temperatura ambiente hasta su cultivo como bioimplante.

El proceso de tallado se realiza en la cabina de flujo laminar y una vez finalizado el proceso se toma una muestra de la matriz hidratada con ayuda de unas pinzas estériles para análisis de control de calidad microbiológico (cultivo microorganismos aerobios y anaerobios). 


\section{CULTIVO DEL BIOIMPLANTE "BIOMAX”}

El cultivo del bioimplante se realiza con la unión de las células MSV-H obtenidas en la fase de expansión y los discos de matriz tridimensional realizada con el suero autólogo.

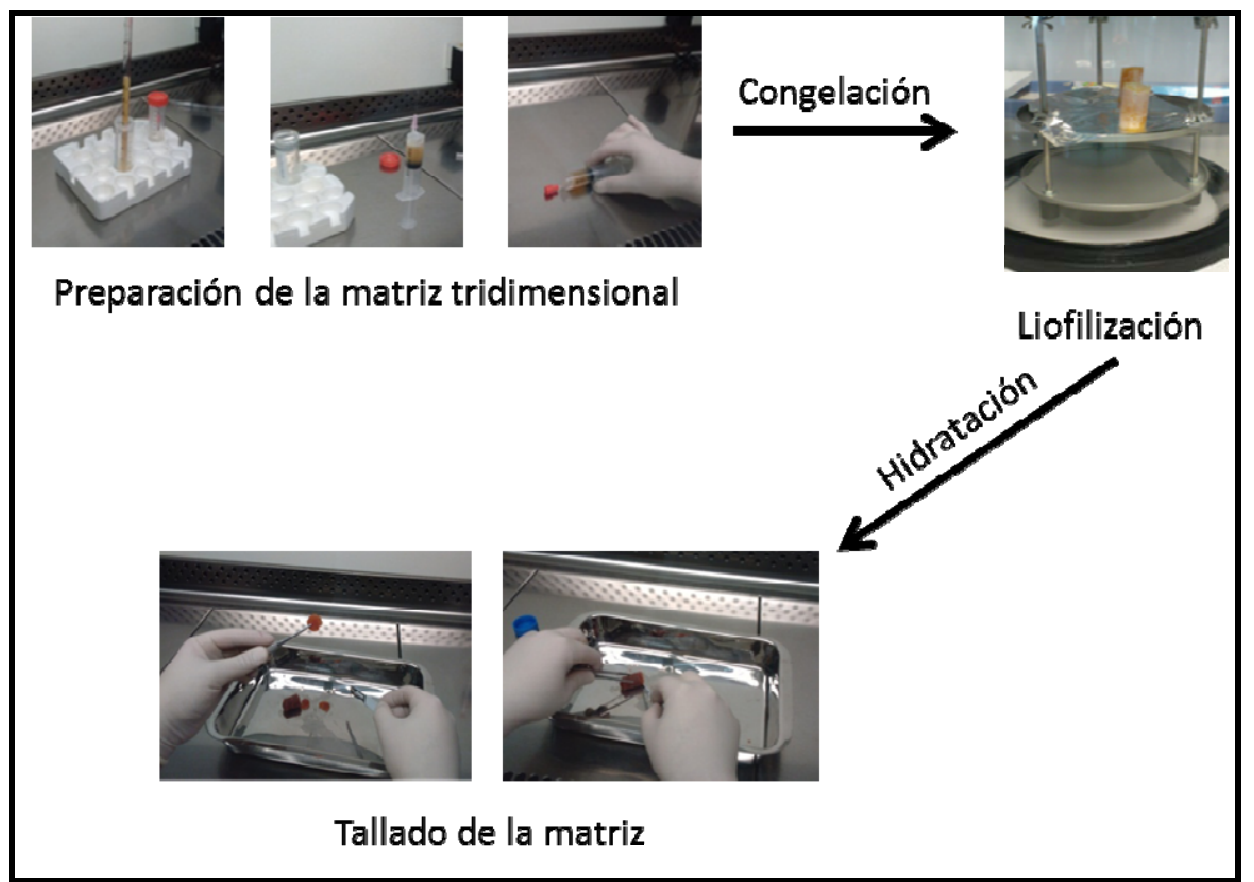

Figura 17: Esquema de producción de la matriz tridimensional

Una vez obtenido el número de células MSV-H necesario para el cultivo de los bioimplantes $\left(5-10 \times 10^{6}\right.$ células/bioimplante), se realizó una última tripsinización para obtener las células en suspensión.

Antes de realizar el cultivo celular del bioimplante, los discos de matriz, conservados en etanol $70^{\circ}$, se lavaron tres veces con $50 \mathrm{ml}$ de medio de cultivo DMEM para eliminar el exceso de etanol. Estos lavados son de $30 \mathrm{~min}$ y el último lavado se recoge para realizar un análisis de control de calidad microbiológico (Hemocultivo y Micoplasma). 
Una vez que tenemos las células en suspensión y los discos de matriz lavados, se recogieron las células necesarias y se centrifugaron a $1400 \mathrm{rpm}$ a $22^{\circ} \mathrm{C}$ durante 10 min. El sedimento celular obtenido se resuspendió en $300 \mu \mathrm{l}$ de medio de cultivo y se sembraron los discos de matriz previamente lavados y colocados en una placa de 6 pocillos. Se dejaron en agitación continua durante 24 horas en el incubador a $37^{\circ} \mathrm{C}$ y $5 \% \mathrm{CO}_{2}$ y pasado este tiempo, se dio la vuelta al bioimplante y dejaron nuevamente 3 horas más en agitación en las mismas condiciones.

El bioimplante sembrado con células MSV-H se pasa a un nuevo pocillo y se añaden $5 \mathrm{ml}$ de medio de diferenciación osteogénica compuesto por DMEM 4,5 g/l de glucosa, 10\% SBF, 1\% Penicilina/Estreptomicina, $0.1 \mu \mathrm{M}$ Dexametasona (Sigma Aldrich), $50 \mu \mathrm{M}$ L-Ascorbato (Sigma Aldrich) y $10 \mathrm{mM}$ ßGlicerofosfato (Sigma Aldrich),

Los bioimplantes se mantuvieron en cultivo entre 20 y 30 días con medio de diferenciación, cambiando el medio de cultivo dos veces por semana, retirando el medio completamente y añadiendo $5 \mathrm{ml}$ de medio de diferenciación nuevo. El medio retirado, se recogió una vez a la semana para realizar análisis de control de calidad microbiológica (Hemocultivo y Micoplasma).

A la vez que se siembran las células en el bioimplante, se siembran otras 50.000 células en un pocillo en una placa de 6 pocillos, en $5 \mathrm{ml}$ de medio de diferenciación osteogénica y se mantienen en las mismas condiciones que los bioimplantes para realizar los controles de calidad del producto, es decir, comprobar que las células MSV-H se diferencian hacia células osteoblásticas. (Ver punto 12).

En este momento se congelan en DMEM $4,5 \mathrm{~g} / \mathrm{l}$ de glucosa, 10\% FBS y $10 \%$ DMSO (Sigma Aldrich), 500.000 células para ser mantenidas como muestra de retención según normativa GMP.

La muestra de retención es una muestra de un producto completamente acondicionado tomada de un lote de producto terminado. Esta sirve como un modelo del lote de producto terminado y puede ser estudiada en caso de reclamaciones de calidad relativas a la forma farmacéutica, dudas sobre el cumplimiento de las especificaciones contenidas en la autorización de comercialización, sobre etiquetado/acondicionado o informes de farmacovigilancia. 
Se deben conservar los registros de trazabilidad de las muestras y las muestras durante 20 años; además estos registros deben estar disponibles para su revisión por las autoridades competentes durante las inspecciones trienales.

\section{PROCESO DE ENVASADO}

Una vez finalizado el tiempo de cultivo en medio de diferenciación, el bioimplante está listo para ser injertado. Retiramos el medio de diferenciación y lavamos el bioimplante con medio DMEM. Este lavado lo recogemos para análisis de control de calidad (Hemocultivo y Micoplasma).

Introducimos el o los bioimplantes en un recipiente estéril (tubo falcon de $50 \mathrm{ml}$ ) con medio DMEM que embolsamos con doble bolsa de papel mixto previamente autoclavada.

Sacamos el producto final por el SAS de salida a la zona de acondicionamiento donde sellamos la bolsa externa e identificamos el producto con su etiqueta correspondiente.

Introducimos el producto correctamente envasado para el transporte en una caja de poliestireno expandido, con un registrador de temperatura en continuo (data-logger) y la documentación correspondiente al producto final.

El transporte se realiza a temperatura ambiente entre 10 y $28^{\circ} \mathrm{C}$ y el implante se efectuará en las 8 horas siguientes a su envasado. El medicamento se transportará en contenedores rígidos validados para mantener la temperatura óptima del producto.

\section{CONTROLES DE CALIDAD DEL BIOIMPLANTE "BIOMAX"}

La Unidad de Producción Celular donde se realiza todo el proceso de fabricación del bioimplante BIOMAX, mantiene unas condiciones de esterilidad, limpieza y control de calidad definidos en los Procedimientos Normalizados de Trabajo (PNT) que establecen las normas de la UPC bajo estándares GMP. Durante todo el proceso se realiza una monitorización ambiental mediante la placas de sedimentación (TSA y SDCI (Biomerieux)) dentro de la cabina de flujo laminar para la detección de bacterias, hongos y levaduras. 
También se realiza una monitorización de las partículas mediante el contador de partículas modelo LASAIR III; y finalmente, una vez terminado el proceso, se hace un control de los guantes del operario mediante la impresión de placas de contacto (CT3P y CTSI (Biomerieux)) para la detección de bacterias, hongos y levaduras.

Además de los controles ambientales y del operario, se realizan diferentes controles al producto: controles microbiológicos, análisis fenotípico células MSV-H por citometría de flujo y control de diferenciación de las células MSV-H.

\section{- Controles microbiológicos}

El proceso completo de producción de una matriz tridimensional, expansión MSV-H y cultivo bioimplantes presenta diferentes puntos críticos donde se realizaron controles microbiológicos y de calidad bacteriana

Los puntos analizados fueron:

1. Obtención de suero: se analizaron $500 \mu \mathrm{l}$ del suero autólogo.

2. Hueso esponjoso: se analizó el medio de recogida de la muestra de tejido óseo mandibular.

3. Matriz tridimensional: se realizaron tres análisis diferentes: matriz liofilizada (explantes), hidratada (explantes) y medio del último lavado de los discos de matriz.

4. Células MSV-H: se analizó el sobrenadante celular en los dos primeros cambios de medio y luego una vez a la semana.

5. Tripsinización: se analizó el sobrenadante celular previo a la tripsinización.

6. Bioimplante: se analizó el sobrenadante celular en el cambio de medio, una vez a la semana, y el sobrenadante del último lavado, antes de enviar el bioimplante (para detectar la posible contaminación tras su manipulación).

Una vez recogidas las muestras se enviaron al laboratorio de Control de Calidad donde se realizaron controles de esterilidad. Los sobrenadantes se analizaron mediante un sistema automatizado "Bact Alert" (Bact Alert iFA y Bact Alert iFN; Biomerieux) para la detección de microorganismos aerobios y anaerobios. Con los explantes se realizó siguiendo los métodos de la farmacopea clásica, con siembra de las muestras de la matriz en caldos de cultivo microbiológico: Tioglicolato (Biomerieux) para la detección de anaerobios y TSB-T (Biomerieux) para la 
detección de aerobios mesófilos, hongos y levaduras. En la Tabla 6 se muestra un resumen de los controles de calidad realizados en el proceso de fabricación del bioimplante BIOMAX.

Tabla 6. Controles proceso de fabricación bioimplante BIOMAX

\begin{tabular}{|c|c|c|c|}
\hline Fases & $N^{\circ}$ de muestras & Control & $\begin{array}{c}\text { Mecanismo de } \\
\text { muestreo }\end{array}$ \\
\hline \multirow{2}{*}{ Obtención de suero } & $\begin{array}{l}\text { Placas de Control de } \\
\text { ambiente y guantes }\end{array}$ & Monitorización de proceso & $\begin{array}{l}\text { Sedimentación } \\
\text { campana/ Impresión de } \\
\text { guantes }\end{array}$ \\
\hline & $500 \mu \mathrm{l}$ a $1 \mathrm{ml}$ suero & $\begin{array}{l}\text { Esterilidad de producto } \\
\text { (Hemocultivo/Micoplasma) }\end{array}$ & Inoculación directa \\
\hline \multirow{4}{*}{$\begin{array}{l}\text { Preparación de matriz } \\
\text { tridimensional }\end{array}$} & $\begin{array}{l}\text { Placas de Control de } \\
\text { ambiente y guantes }\end{array}$ & Monitorización proceso & $\begin{array}{l}\text { Sedimentación } \\
\text { campana/ Impresión de } \\
\text { guantes }\end{array}$ \\
\hline & $\begin{array}{l}\text { Muestra producto } \\
\text { liofilizado }\end{array}$ & $\begin{array}{l}\text { Esterilidad de producto } \\
\text { (Aerobios/anaerobios) }\end{array}$ & Explante para cultivo \\
\hline & $\begin{array}{l}\text { Muestra producto } \\
\text { hidratado y tallado }\end{array}$ & $\begin{array}{l}\text { Esterilidad de producto } \\
\text { (Aerobios/anaerobios) }\end{array}$ & Explante para cultivo \\
\hline & $\begin{array}{l}\text { Sobrenadante del último } \\
\text { lavado }\end{array}$ & $\begin{array}{l}\text { Esterilidad de producto } \\
\text { (Hemocultivo/Micoplasma) }\end{array}$ & Jeringa estéril \\
\hline \multirow{2}{*}{$\begin{array}{l}\text { Procesamiento } \\
\text { muestra ósea }\end{array}$} & $\begin{array}{l}\text { Placas de Control de } \\
\text { ambiente y guantes }\end{array}$ & Monitorización de proceso & $\begin{array}{l}\text { Sedimentación } \\
\text { campana/ Impresión de } \\
\text { guantes }\end{array}$ \\
\hline & $\begin{array}{l}\text { Sobrenadante medio de } \\
\text { trasporte }\end{array}$ & $\begin{array}{l}\text { Esterilidad de producto } \\
\text { (Hemocultivo/Micoplasma) }\end{array}$ & Inoculación directa \\
\hline \multirow{3}{*}{$\begin{array}{l}\text { Cambio medio } \\
\text { ( } 2 \text { veces por semana) }\end{array}$} & $\begin{array}{l}\text { Placas de Control de } \\
\text { ambiente y guantes }\end{array}$ & Monitorización de proceso & $\begin{array}{l}\text { Sedimentación } \\
\text { campana/ Impresión de } \\
\text { guantes }\end{array}$ \\
\hline & $\begin{array}{l}\text { Sobrenadante dos } \\
\text { primeros cambios de } \\
\text { medio }\end{array}$ & $\begin{array}{l}\text { Esterilidad de producto } \\
\text { (Hemocultivo/Micoplasma) }\end{array}$ & Inoculación directa \\
\hline & $\begin{array}{l}\text { Sobrenadante del medio } \\
\text { (una vez a la semana) }\end{array}$ & $\begin{array}{l}\text { Esterilidad de producto } \\
\text { (Hemocultivo/Micoplasma) }\end{array}$ & Inoculación directa \\
\hline \multirow{5}{*}{ Tripsinización } & $\begin{array}{l}\text { Placas de Control de } \\
\text { ambiente y guantes }\end{array}$ & Monitorización de proceso & $\begin{array}{l}\text { Sedimentación } \\
\text { campana/ Impresión de } \\
\text { guantes }\end{array}$ \\
\hline & $\begin{array}{l}\text { Sobrenadante medio de } \\
\text { cultivo }\end{array}$ & $\begin{array}{l}\text { Esterilidad de producto } \\
\text { (Hemocultivo/Micoplasma) }\end{array}$ & Inoculación directa \\
\hline & $20 \mu$ l suspensión celular & Contaje y viabilidad & $\begin{array}{l}\text { Pipeta con punta } \\
\text { apirógena y estéril }\end{array}$ \\
\hline & 500.000 células & Muestra de retención & Pipeta con punta estéril \\
\hline & 50.000 células & $\begin{array}{l}\text { Control Calidad del } \\
\text { producto: Diferenciación }\end{array}$ & Pipeta con punta estéril \\
\hline $\begin{array}{l}\text { Sembrar células en la } \\
\text { matriz (Bioimplante) }\end{array}$ & $\begin{array}{l}\text { Placas de Control de } \\
\text { ambiente y guantes }\end{array}$ & Monitorización de proceso & $\begin{array}{l}\text { Sedimentación } \\
\text { campana/ Impresión de } \\
\text { guantes }\end{array}$ \\
\hline \multirow{2}{*}{$\begin{array}{l}\text { Cambio medio } \\
\text { diferenciación } \\
\text { osteogenica } \\
\text { ( } 2 \text { veces por semana) }\end{array}$} & $\begin{array}{l}\text { Placas de Control de } \\
\text { ambiente y guantes }\end{array}$ & Monitorización de proceso & $\begin{array}{l}\text { Sedimentación } \\
\text { campana/ Impresión de } \\
\text { guantes }\end{array}$ \\
\hline & $\begin{array}{l}\text { Sobrenadante del medio } \\
\text { (una vez a la semana) }\end{array}$ & $\begin{array}{l}\text { Esterilidad de producto } \\
\text { (Hemocultivo/Micoplasma) }\end{array}$ & Inoculación directa \\
\hline \multirow{2}{*}{ Envío } & $\begin{array}{l}\text { Placas de Control de } \\
\text { ambiente y guantes }\end{array}$ & Monitorización de proceso & $\begin{array}{l}\text { Sedimentación } \\
\text { campana/ Impresión de } \\
\text { guantes }\end{array}$ \\
\hline & $\begin{array}{l}\text { Sobrenadante lavado } \\
\text { final }\end{array}$ & $\begin{array}{l}\text { Esterilidad de producto } \\
\text { (Hemocultivo/Micoplasma) }\end{array}$ & Inoculación directa \\
\hline
\end{tabular}




\section{- Análisis fenotípico células MSV-H por citometría de flujo}

El control fenotípico de las células MSV-H se realizó mediante un análisis de los antígenos de superficie por citometría de flujo, lo que nos permitió comprobar la presencia de los marcadores específicos de células mesenquimales.

Este análisis se realizó antes de introducir las células en la matriz (Figura 18). Se preparó para ello una suspensión de $10^{6}$ células MSV-H en $2 \mathrm{ml}$ de PBS (Gibco). Se repartieron las células en 4 tubos (250.000 células/tubo en $500 \mu \mathrm{l})$ y se marcaron con el patrón de anticuerpos (ImmunoStep) que se muestra en la Tabla 7 , en las dosis recomendadas por el fabricante.

Tabla 7: Patrón de anticuerpos para análisis por citometría

\begin{tabular}{|c|c|c|c|}
\hline 1 & \multicolumn{3}{|c|}{ CONTROL } \\
\hline 2 & CD 14 & CD 166 & CD 34 \\
\hline 3 & CD 45 & CD 73 & CD 90 \\
\hline 4 & CD 105 & HLA-DR & CD 90 \\
\hline
\end{tabular}

Los tubos se incuban en oscuridad a $4^{\circ} \mathrm{C}$ durante 20 minutos. Pasado este tiempo se añaden $2,5 \mathrm{ml}$ de PBS para lavar y se centrifugan $5 \mathrm{~min}$ a $2000 \mathrm{rpm}$. Retiramos el sobrenadante y resuspendemos el sedimento celular en $500 \mu \mathrm{l}$ de PBS antes de pasar la muestra por el citómetro de flujo Gallios (Beckman Coulter).

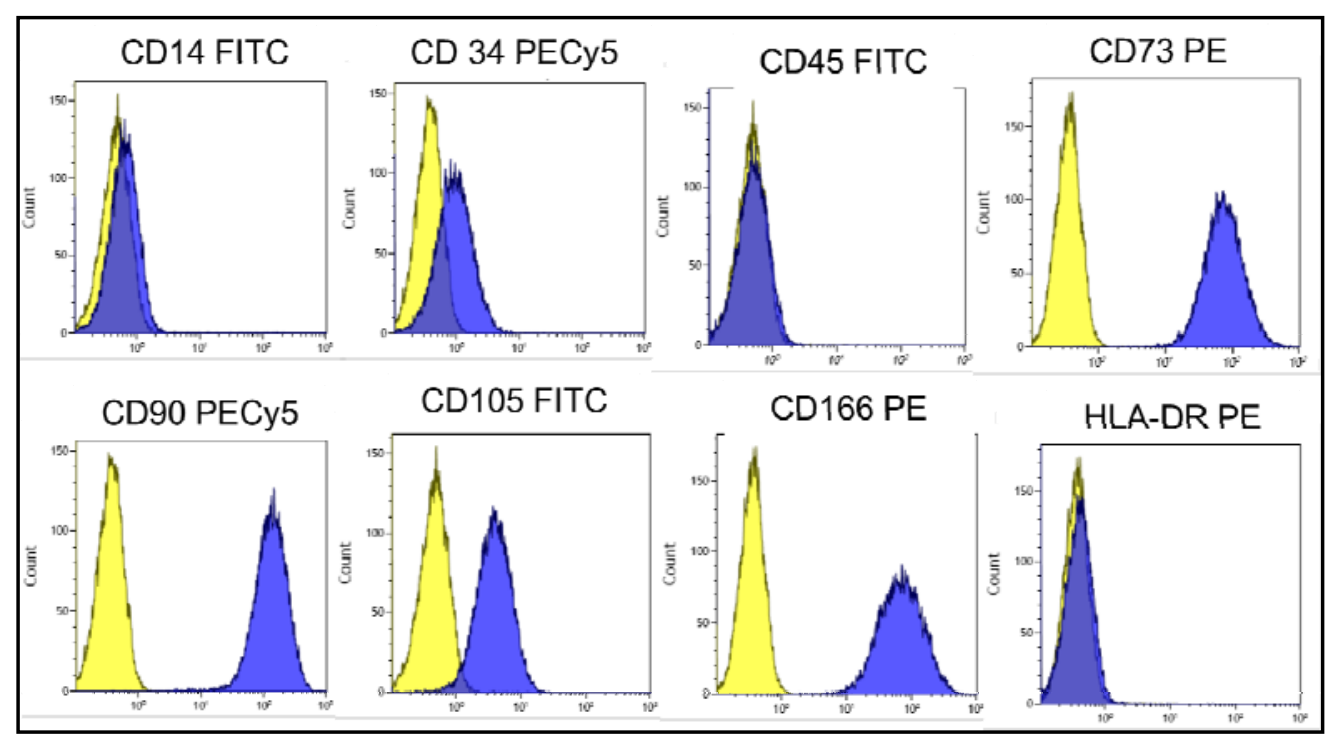

Figura 18: Caracterización inmunofenotípica las células MSV-H.

Análisis por citometría de flujo comparando MSV-H (azul) con controles isotópico (Amarillo) 
Las MSV-H fueron fuertemente positivas para CD73, CD90 y CD166, débilmente positivas para CD105, y negativas para CD14, CD34, CD45 y HLA-DR.

\section{- Control diferenciación de las células MSV-H}

El control de diferenciación se realizó para determinar si las células MSV-H cultivadas en el bioimplante presentaban un fenotipo osteoblástico, es decir, se habían diferenciado para la formación de matriz ósea; De esta manera, se ratificaba la presencia de células MSV-H diferenciadas dentro del bioimplante que se envía.

Para realizar este control se tomaron s 50.000 células MSV-H y se sembraron en un pocillo de una placa de 6 pocillos con $5 \mathrm{ml}$ de medio de diferenciación osteogenico a la vez que siembran en la matriz tridimensional. Las células se mantuvieron en cultivo dentro de la UPC de forma paralela a los bioimplantes el mismo tiempo y con el mismo medio de diferenciación.

Una vez terminado el proceso de envasado del bioimplante, se sacó el cultivo paralelo de células de la sala GMP para realizar los controles de diferenciación. Se realizó una tinción de fosfatasa alcalina, ya que una vez que las células osteoprogenitoras inician su diferenciación hacia osteoblastos, comienzan a expresar otros componentes del hueso entre los que destacan: colágeno, fosfatasa alcalina, osteocalcina y osteonectina.

La tinción de fosfatasa alcalina (FA; Figura 19) se realizó con un Kit (Fast Red Subtrate Pack For use with Alkaline Phosphatase Detection Kits or BioGenex Automated Staining Systems), y es una tinción que nos permitió comprobar que las células osteoprogenitoras (MSV-H) habían iniciado la diferenciación osteoblástica y habían empezado a sintetizar matriz ósea.

El protocolo a seguir es:

- Disolver una pastilla del Rojo Rápido (Fast Red) en $5 \mathrm{ml}$ del sustrato (substrato con naftol-fosfato en Tris buffer).

- Agitar la mezcla hasta la completa disolución de la pastilla (tarda unos minutos y hay que utilizarla a partir de los $30 \mathrm{~min}$ de su preparación). Esta solución es estable durante 8 horas a temperatura ambiente. 
- Eliminar el medio de cultivo de la placa con una pipeta pasteur y lavar las células con $5 \mathrm{ml}$ PBS (no es necesario que sea estéril).

- Eliminar el PBS con una pipeta Pasteur.

- Añadir unas gotas de la mezcla anterior filtrada, hasta cubrir el fondo del pocillo (aprox $1 \mathrm{ml}$ ).

- Incubar de 5 a 40 min a temperatura ambiente y en oscuridad (Máxima tinción a los $30 \mathrm{~min}$ ). Las células positivas para FA se tiñen de rojo con este Kit)

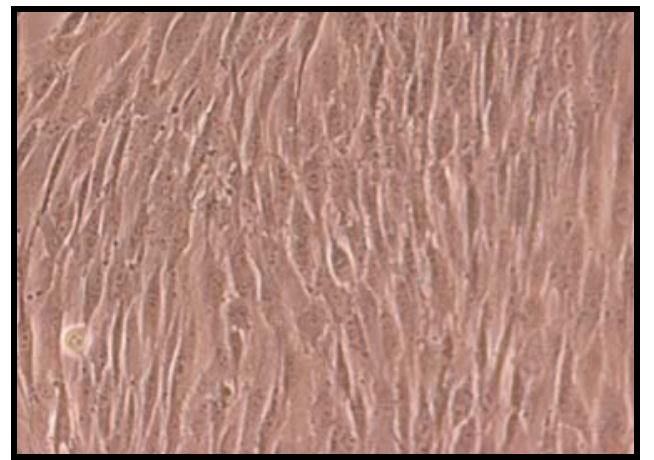

Control negativo

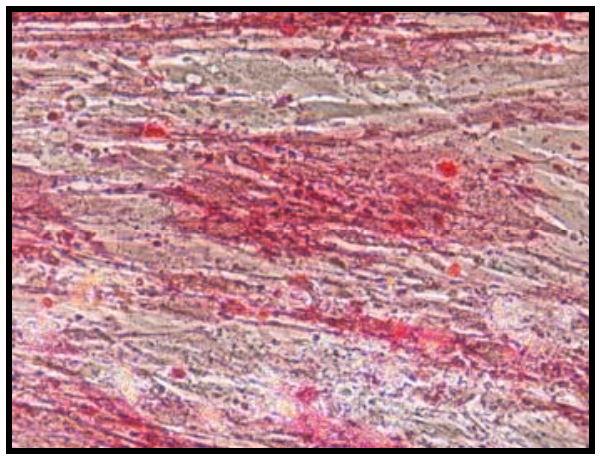

Control positivo

Figura 19: Tinción con FA.

\section{APLICACIÓN DEL BIOIMPLANTE "BIOMAX"}

La aplicación de bioimplante BIOMAX se realiza en el gabinete de Cirugía Maxilofacial del HURH por personal especializado y con instrumental quirúrgico estéril individualizado para cada paciente. El implante celular se realiza tras la ostectomía y enucleación del quiste maxilar/mandibular (Figura 20).

El paciente se coloca en posición de procedimiento de cirugía oral, acomodado en el sillón dental del gabinete y se aplica anestesia local intraoral permucosa o troncular, para el bloqueo anestésico de la zona a intervenir, con jeringa de carpule (jeringa dental) utilizando cartuchos de $1,8 \mathrm{ml}$ de articaína $(\mathrm{DCl}$, clorhidrato de articaína DCl clorhidrato $40 \mathrm{mg} / \mathrm{ml}$ ) y epinefrina (en forma de bitartrato: 0,01 mg por cada $\mathrm{ml}$ ). Se han utilizado de 1 a 3 cartuchos para cada procedimiento. 
El abordaje quirúrgico consistió en una incisión mucosa sobre la encía queratinizada de la cresta alveolar y elevación de un colgajo mucoperióstico tipo Newman (colgajo trapezoidal de base en vestíbulo mucoso). Este tipo de técnica no precisa habitualmente hemostasia con cauterio.

La lesión quística ósea se abordó mediante ostectomía de la pared ósea vestibular con fresa redonda de carburo de tungsteno (diámetro: $2 \mathrm{~mm}$ ) montada sobre pieza de mano con refrigeración, luz fría y a 80-100.000 rpm (revoluciones por minuto), bajo irrigación con agua destilada. La membrana quística se enucleó, se fijó en formol y se etiqueto para estudio anatomopatológico.

Una vez enucleado el quiste, se aplicaron las unidades de bioimplante BIOMAX necesarias para el relleno de la cavidad ósea residual. Cada unidad de $2 \mathrm{~cm}$ de diámetro y $30 \mathrm{~mm}$ de espesor contiene de 5 a 10 millones de células MSV-H.

Finalmente, se repone el colgajo mucoperióstico para el cierre directo primario del lecho quirúrgico y se sutura con material reabsorbible (Vicryl 4/0) sobre aguja atraumática.

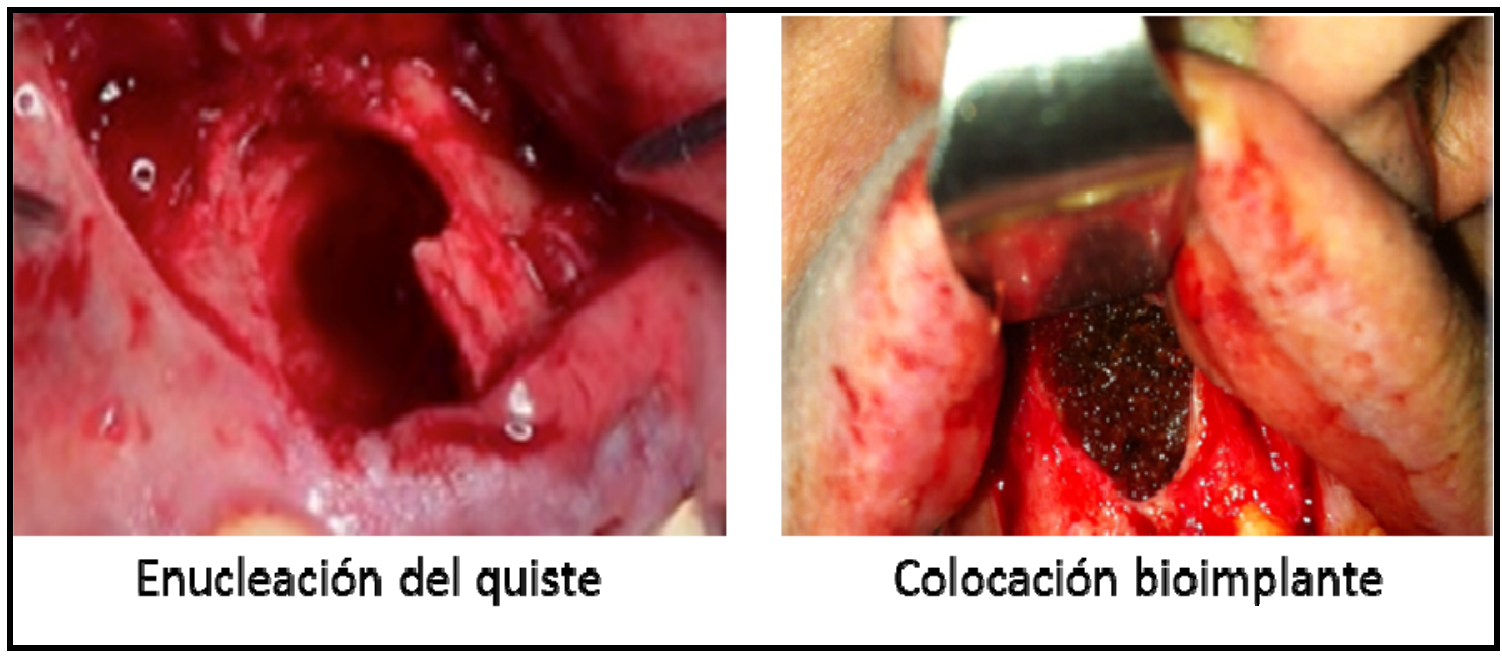

Figura 20. Técnica quirúrgica para aplicación del bioimplante Biomax. 


\section{ANÁLISIS DE RESULTADOS.}

Los resultados de la efectividad del estudio se obtienen mediante el análisis de las densidades de hueso en la zona de la mandíbula afectada por el quiste antes del tratamiento y a los seis meses de realizar el tratamiento con el bioimplante BIOMAX. Además, se realiza una comparación de los resultados de las densidades de hueso en la zona afectada y en una zona sana del mismo paciente en el otro lado de la mandíbula afectada, que se toma como control. El control se estudia en las mismas imágenes y condiciones, antes del tratamiento y a los seis meses de realizar el mismo.

Las regiones de interés (ROI) para la determinación de la densidad ósea son siempre de una superficie de 22,2 $\mathrm{mm}^{2}$. Se realizan 3 medidas en el eje $Z$ en cortes de $1 \mathrm{~mm}$ cada uno, que se promedian para obtener un valor más representativo.

\section{- Análisis estadístico.}

Las comparaciones se realizaron siempre entre las muestras emparejadas (pre y post tratamiento) utilizando el test no paramétrico de Wilcoxon. En todos los casos, el emparejamiento fue significativo con un coeficiente de Spearman alto. El test de Wilcoxon se eligió porque esta prueba permite trabajar con tamaños muestrales pequeños y datos apareados como es este caso $(n=9)$. Los cálculos estadísticos se realizaron utilizando el programa GraphPad InStat v.3.06. 

RESULTADOS 



\section{RESULTADOS PRECLINICOS PREVIOS}

El ensayo clínico se desarrolla a partir de una investigación previa basada en los estudios preclínicos realizados "in Vitro" e "in Vivo" en colaboración con el CCST y el HUCA de Asturias y el HURH de Valladolid.

\subsection{Estudio "in Vitro"}

En esta parte del proyecto se puso a punto la técnica para obtener y cultivar las células mesenquimales de hueso (MSV-H). Se procesaron fragmentos de hueso esponjoso mandibular obtenidos de pacientes del servicio de Cirugía Maxilofacial del HURH de Valladolid tras firmar un consentimiento informado. A partir de estos explantes se obtuvieron las células MSV-H, que se expandieron in Vitro en el laboratorio de investigación del IBGM de Valladolid. Estas células se sembraron sobre la matriz de suero entrecruzado y se mantuvieron en cultivo durante 21 días con medio de diferenciación osteogénica.

La matriz se realizó a partir de suero de donantes del CCST de Asturias.

Los bioimplantes fabricados "in Vitro" se fijaron en para-formaldehido para realizar estudios histológicos.

En la Figura 21 se muestra una tinción con hematoxilina-eosina (izquierda), que nos permitió demostrar el anidamiento de las células en el interior de la matriz y la tinción de Von Kossa (derecha) nos muestra los depósitos de calcio que presentan las células dentro de la matriz, lo que nos indica que se han diferenciado y que han iniciado una fase de mineralización ósea.

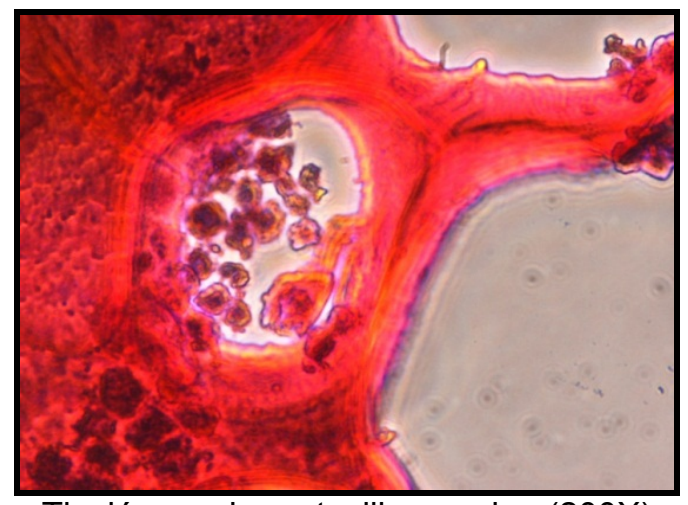

Tinción con hematoxilina-eosina (200X)

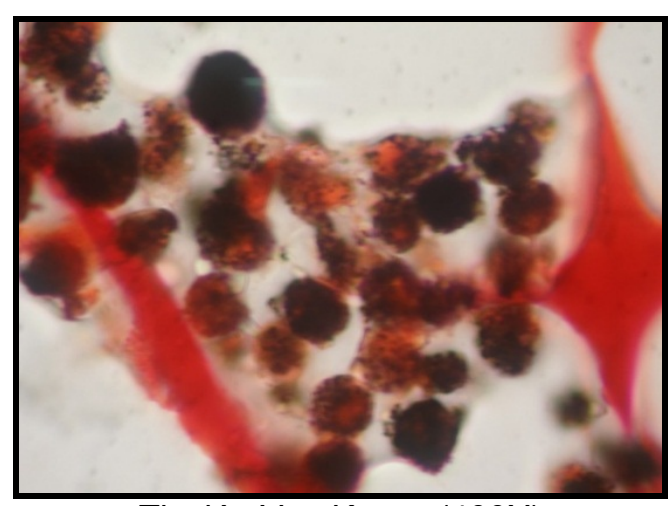

Tinción Von Kossa (400X)

Figura 21. Estudio histológico matriz sembrada con células MSV-H diferenciadas. 
Otros bioimplantes se fijaron y se observaron mediante microscopia electrónica de barrido. En ellos puede verse la naturaleza porosa de la matriz y las células adheridas a la misma (Figura 22).
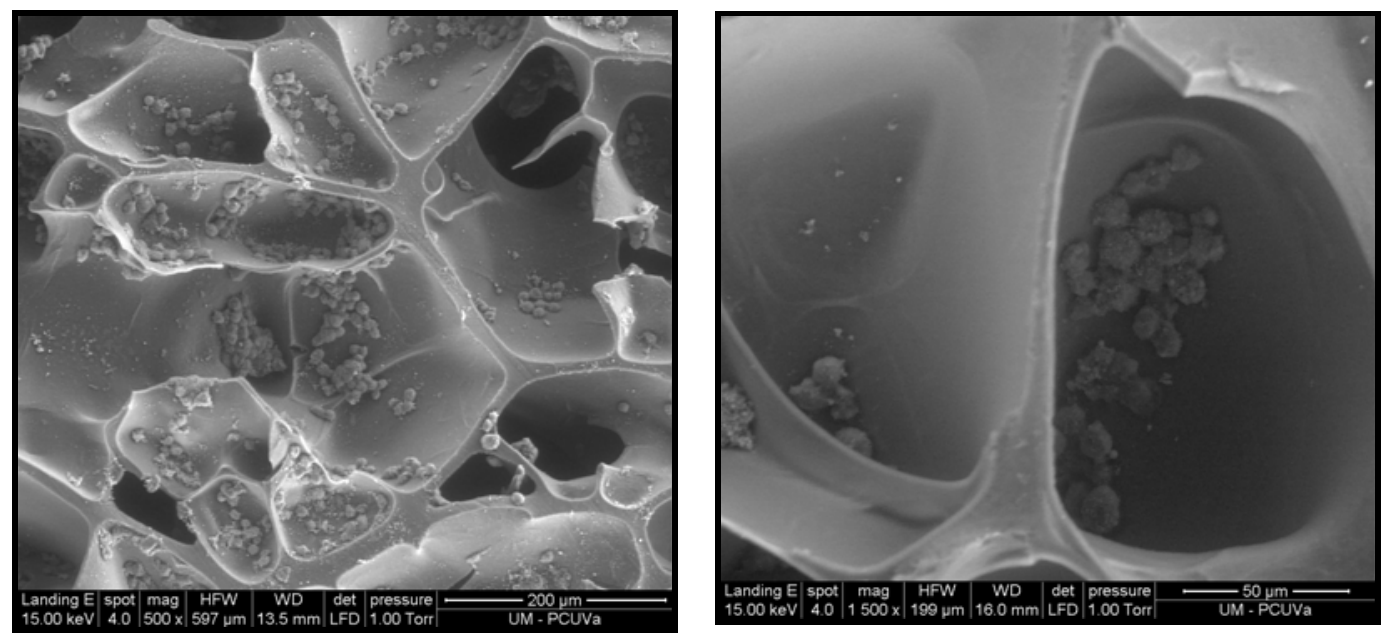

Figura 22. Imágenes microscopio electrónico de barrido

\subsection{Estudios "in Vivo"}

Los estudios "in Vivo" se realizaron siempre utilizando las células MSV-H humanas descritas anteriomente en ratas y ratones atímicos.

Los primeros estudios se realizaron en la Universidad de Oviedo en colaboración con la doctora Lorena Gallego López (resultados detallados en su trabajo de tesis doctoral). En estos estudios se realizaron en principio injertos heterotópicos en el dorso de 5 ratones atímicos y posteriormente se realizaron injertos ortotópicos en defectos críticos mandibulares en 6 ratas atímicas; en ambos casos se han utilizado animales atímicos porque se han realizado los injertos con matriz de suero humano y células mesenquimales humanas obtenidas de hueso.

Los resultados histológicos a los 75 días de los injertos heterotópicos nos permitieron demostrar con tinciones de vimentina y osteocalcina humana que la actividad osteoblástica que se producía en los injertos se debía a las células de origen humano sembradas en la matriz (Figura 23). 


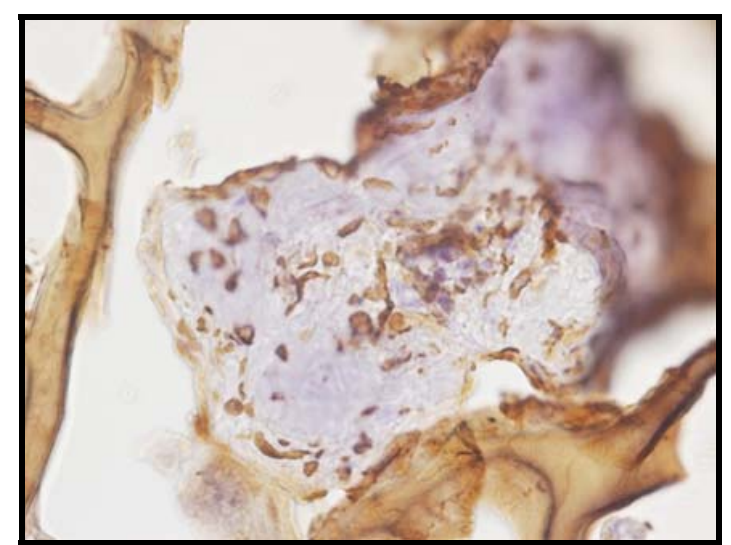

Tinción con Vimentina humana (400X)

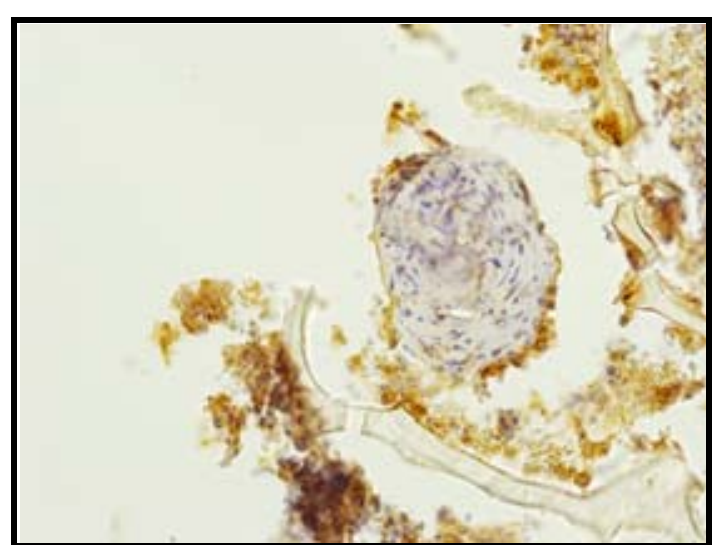

Tinción Ostoeocalcina humana (200X)

Figura 23. Estudio histológico injerto dorso ratones atímicos

Por otro lado, se realizaron estudios de imagen de tomografía computarizada (TC) siguiendo la evolución de los defectos críticos mandibulares tratados con las células MSV-H diferenciadas incluidas en la matriz de suero o sin nada (control). Los resultados radiológicos a las 11 semanas nos muestran una reparación con ocupación del defecto crítico en la zona injertada con matriz más células MSV-H (lado derecho de la mandíbula), mientras que en la zona control (lado izquierdo de la mandíbula) puede aún distinguirse claramente el defecto crítico generado. (Figura 24).

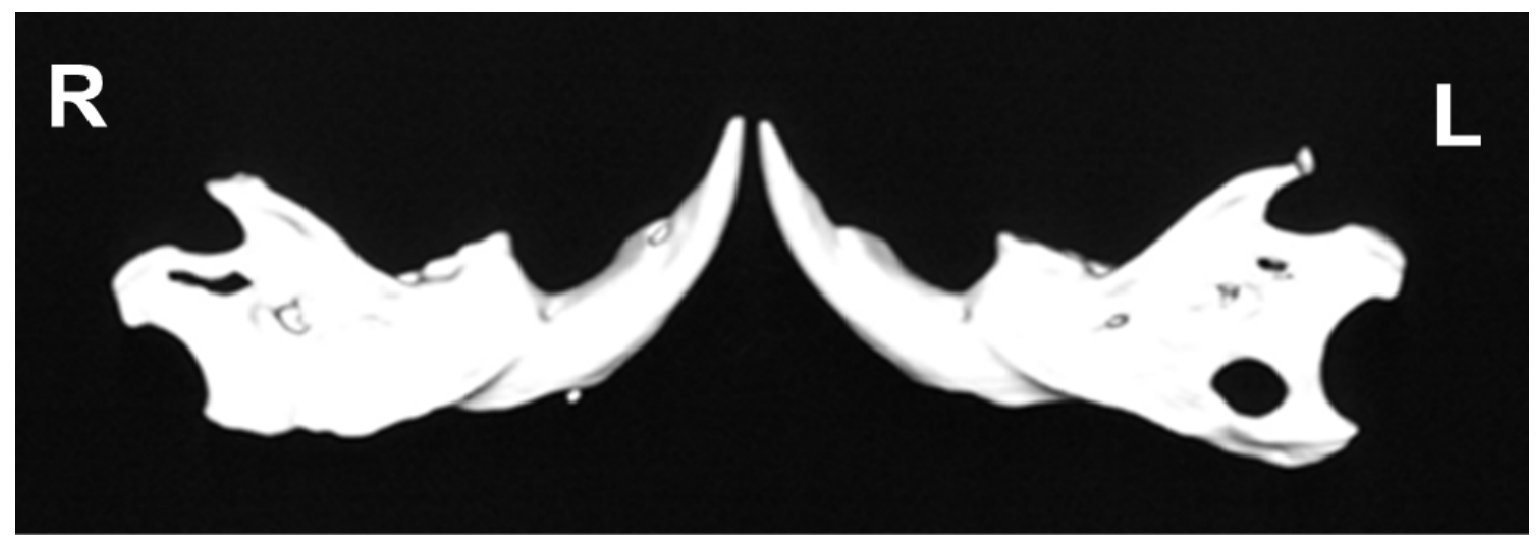

Figura 24. Imagen de TC hemimandíbulas a las 8 semanas de realizar el injerto.

En lado derecho $(R)$ el defecto se rellenó con una matriz con células mesenquimales diferenciadas y presenta regeneración del tejido óseo y en el lado izquierdo (L) control, se aprecia una zona radiolúcida sin signos de osteoformación.

Este trabajo se continuó mediante la colaboración con grupo del Dr. Luis Miguel Redondo, principalmente con el doctorando Javier Fernández Doval (resultados detallados en el trabajo de su tesis doctoral). 
Este estudio se realizó en 12 ratas atímicas divididas en 4 grupos experimentales:

1. Matriz sin células

2. Matriz con células cultivadas durante 1 día en con medio osteogénico

3. Matriz con células diferenciadas durante 21 días en medio osteogénico

4. Matriz con células en cultivo durante 21 días con medio de cultivo sin factores de diferenciación.

En los cuatro grupos se utilizó una matriz de suero humano y células mesenquimales de hueso humano (MSV-H) obtenidas mediante el cultivo de explantes previamente detallado. $Y$ se han realizado injertos ortotópicos en defectos críticos mandibulares en ratas atímicas e injertos heterotópicos en la región inguinal de las mismas ratas, para valorar la capacidad de vascularización del implante.

Las ratas se sacrificaron a los 3 meses y se realizaron estudios radiológicos e histológicos.

La Figura 25 muestra los resultados histológicos de los injertos ortotópicos en ratas atímicas. Las tinciones de hematoxilina-eosina muestran que la matriz es reabsorbida y sustituida por sustancia intercelular propia del tejido óseo neoformado. $Y$ con tinciones de Giemsa podemos apreciar la formación de vasos a partir del tejido adyacente del receptor, que ha invadido la matriz injertada (Figura 26). La formación de hueso sólo se ha producido en el grupo 3 , lo que era de esperar, ya que este es el grupo con células mesenquimales condicionadas hacia linaje osteoblastico

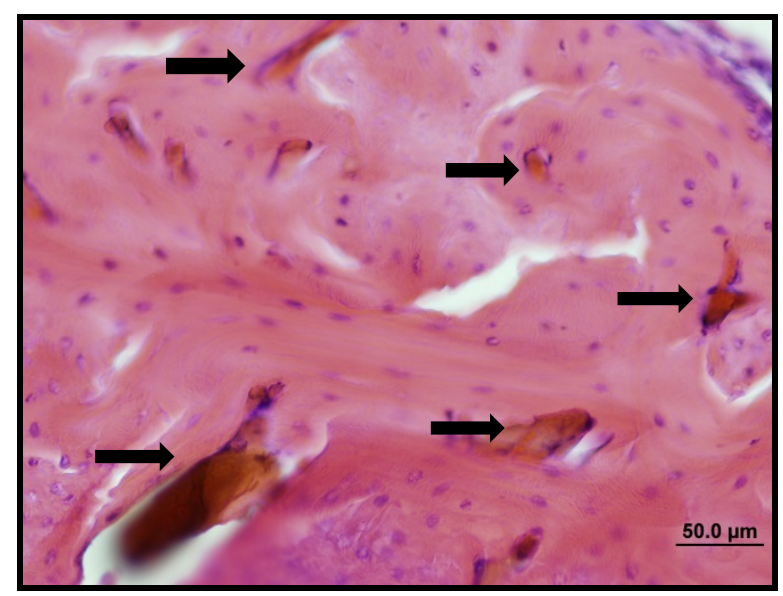

Figura 25. Histología mandíbula rata tratada con bioimplante con células diferenciadas a los tres meses de realizar el injerto. Se ven restos de la matriz rodeada de tejido de nueva formación. 


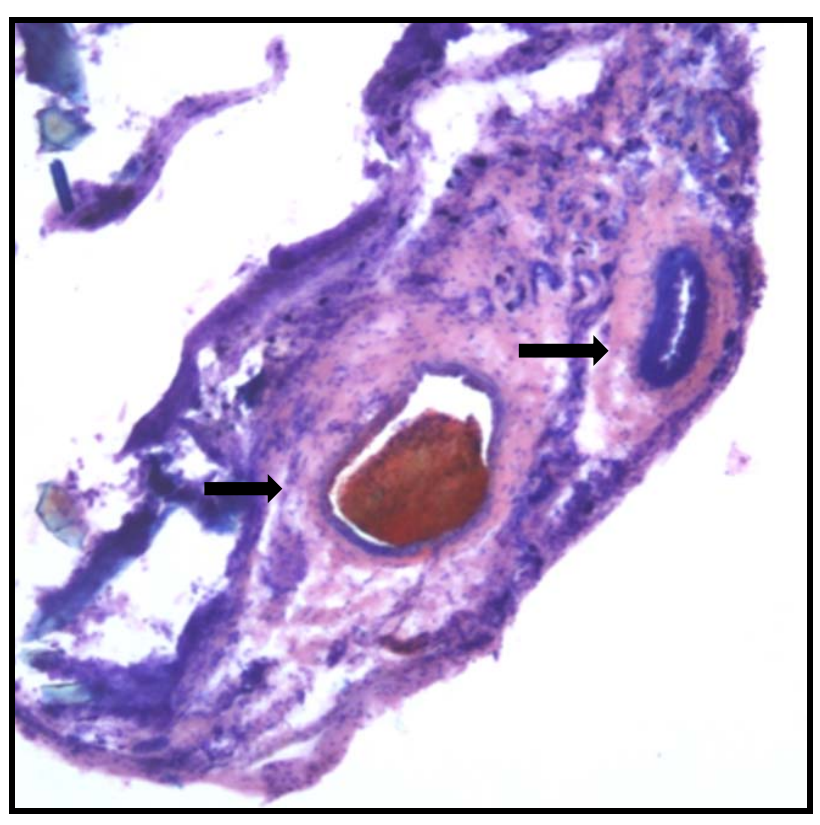

Figura 26. Imagen injerto heterotópico inguinal en ratas atímicas (40x). Imagen de estructuras organizadas que pertenece a vasos sanguíneos formados en el bioimplante injertado a partir de los vasos del tejido adyacente a la zona inertada.

La Figuras 27 y 28 muestran los resultados radiológicos. El análisis de estos resultados no muestran diferencias significativas cuando se hacen comparaciones entre los grupos 1,2 y 3 (matriz, matriz con células 1 día, y matriz con células diferenciadas); sin embargo, si comparamos estos grupos con el grupo 4 (matriz con células sin diferenciar cultivadas durante 21 días) sí aparecen diferencias significativas (resultados detallados en la tesis doctoral del Dr.Fernandez Doval).

Estos resultados se pueden deber a que en los grupos 1 y 2, la matriz no está invadida por células, ya que es matriz sóla o con células cultivadas durante 1 día, por lo que las células de los tejidos circundantes pueden penetrar en la matriz y regenerar el defecto; por otro lado, el grupo 3 presenta una matriz con células diferenciadas, por lo que ya están condicionadas a realizar la regeneración ósea. Sin embargo, el grupo 4 presenta la matriz cultivada durante 21 con células MSV-H sin diferenciar, por lo que estas células ocupan la superficie de la matriz evitando la penetración de las células de los tejidos circundantes y como no están diferenciadas, no están condicionadas para la regeneración ósea. 


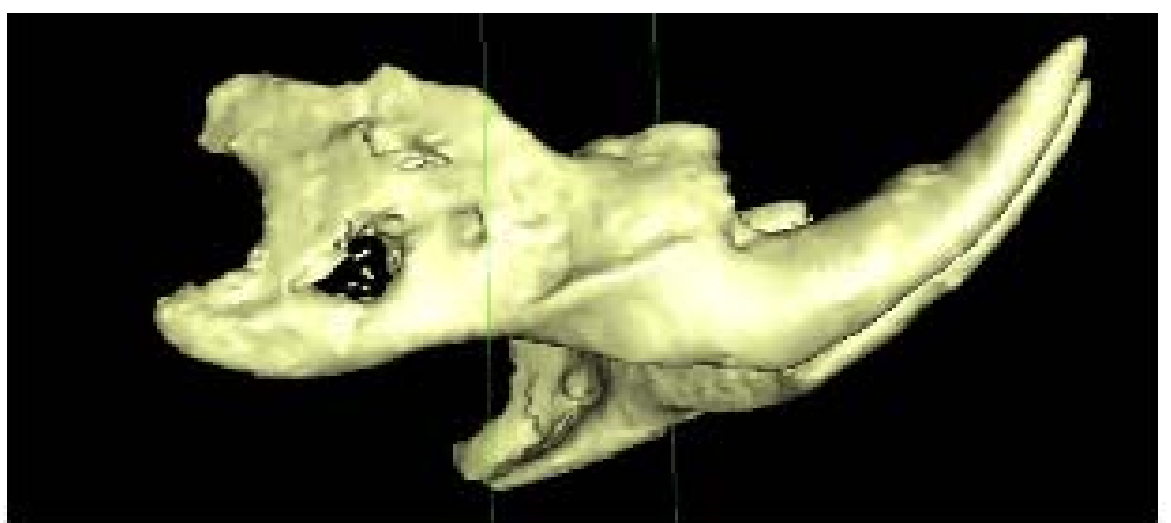

Figura 27. Mandíbula grupo 4 (matriz con célula sin diferenciar durante 21 días), se puede ver la zona del defecto sin signos de formación de hueso nuevo.

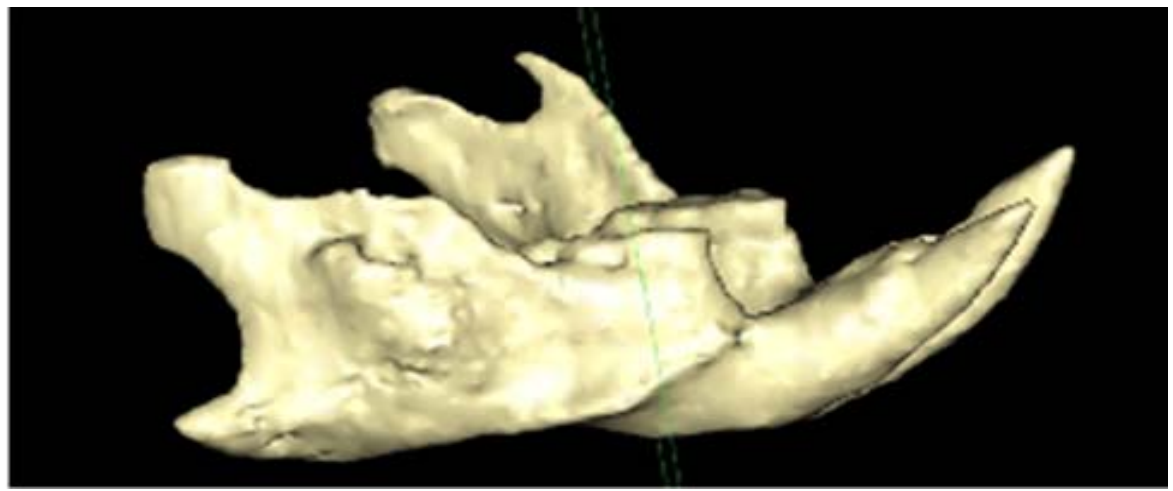

Figura 28. Mandíbula grupo 3 (matriz con células diferenciadas), en la que el defecto generado ha sido rellenado por hueso de nueva formación.

En todos los casos evaluados, los mejores resultados se obtuvieron en el grupo 3, por lo que a partir de aquí se desarrolló en ensayo clínico que nos ocupa con bioimplantes de matriz sembrada con células MSV-H y cultivada durante 21 días con medio de diferenciación osteogénica.

El siguiente ensayo se realizó comparando el injerto de matrices conteniendo células MSV-H diferenciadas con matrices sin células; recubiertas o no con una membrana reabsorbible de ácido poliglicólico-poliláctico (BioMesh-S®). El injerto se colocó en un defecto critico mandibular practicado en 12 ratas atímicas, que se han sacrificaron a las 12 semanas. Estos experimentos se practicaron en colaboración con el grupo del Dr. Luis Miguel Resondo y su estudio completo se desarrolla en el trabajo de tesis doctoral del Dr. Gonzalo de la Peña. 
Las imágenes DICON del TC fueron analizadas con el software Osirix $\AA^{\text {. En }}$ general, se observa que la densidad radiológica en la zona del defecto es menor que la del hueso sano. Además, la densidad radiológica es mayor en la zona del implante contigua al hueso sano; como se puede ver en la Figura 29. Es posible que las 12 semanas que ha durado este ensayo no haya sido tiempo suficiente para permitir la regeneración completa del defecto generado y además, no se han observado diferencias entre los grupos a estudio, por lo que la membrana reabsorbible utilizada no influye en el proceso de regeneración ósea.

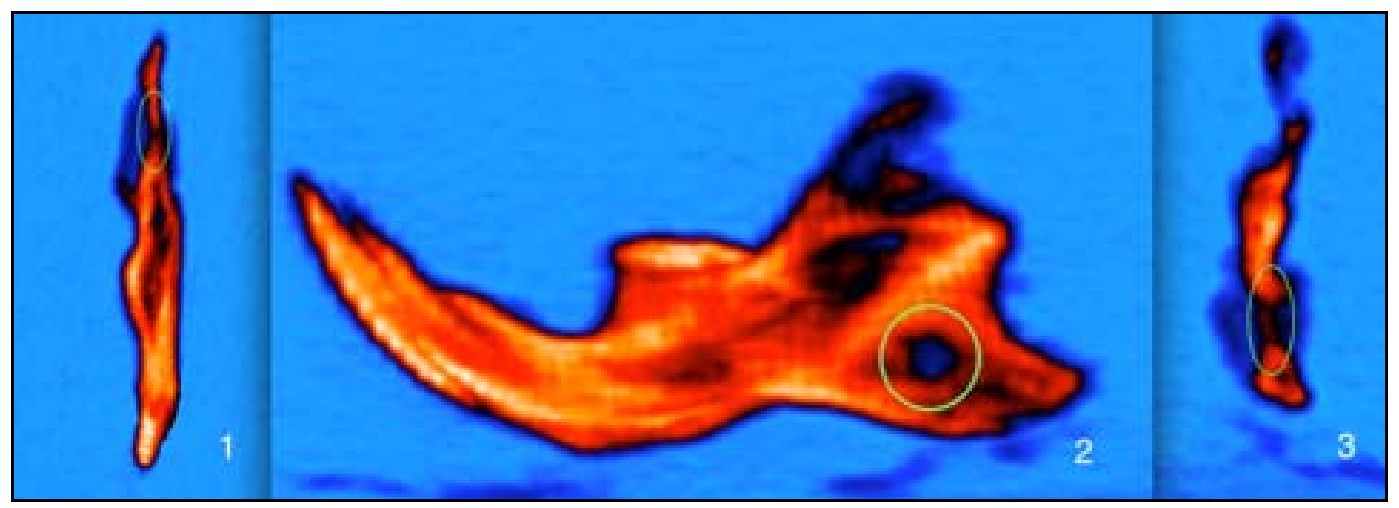

Figura 29. Hemimandíbula en el plano axial (1), sagital (2) y coronal (3).

El defecto generado se corresponde con la elipse verde, lo que nos permite observar que la densidad radiológica es mayor en la zona periférica del defecto, adyacente al hueso sano, que en la zona central del defecto.

En base a estos resultados preclínicos se diseñó el ensayo clínico que se describe a continuación, con el objetivo final de elevar a la categoría de medicamento el bioimplante "BIOMAX" formado con la matriz con células diferenciadas.

\section{INCLUSIÓN DE PACIENTES}

Se han incluido 11 pacientes sanos del Servicio de Cirugía Oral y Maxilofacial del HURH de Valladolid, en edades comprendidas entre 18 y 65 años y con una lesión quística dentaria radicular maxilar de 2 a $4 \mathrm{~cm}$ sin signos de infección; por lo que presentaban todos los criterios de inclusión para participar en el ensayo clínico y ninguno de exclusión. (Ver Tabla 5 en el punto 5 de Material y Métodos). 
Las edades y el sexo de los pacientes se indican en laTabla 8.

Tabla 8. Pacientes incluidos en el EC.

\begin{tabular}{|c|c|c|c|c|}
\hline \multicolumn{2}{|c|}{ PACIENTES } & \multirow{2}{*}{ Sexo } & \multirow{2}{*}{ Edad } & \multirow{2}{*}{ TRATAMIENTO } \\
\cline { 1 - 2 } Número & Identificación & & & \\
\hline 1 & LRC & MUJER & 25 & No realizado * \\
\hline 2 & AAMP & MUJER & 47 & Realizado \\
\hline 3 & ICM & MUJER & 20 & Realizado \\
\hline 4 & GOC & HOMBRE & 44 & Realizado \\
\hline 5 & MMS & MUJER & 21 & Realizado \\
\hline 6 & MTSB & MUJER & 50 & Realizado \\
\hline 7 & VSJA & MUJER & 27 & No realizado * \\
\hline 8 & MCM & HOMBRE & 39 & Realizado \\
\hline 9 & MGGB & MUJER & 54 & Realizado \\
\hline 10 & CCG & MUJER & 20 & Realizado \\
\hline 11 & MYJB & MUJER & 50 & Realizado \\
\hline
\end{tabular}

Los pacientes LRC y VSJA no recibieron el tratamiento debido a la contaminación bacteriana de la muestra inicial.

\section{ESTUDIO RADIOLÓGICO}

A los pacientes incluidos en el EC se les realizo una ortopantomografía para evaluar el defecto quístico mandibular a reparar, sus dimensiones y la densidad de la trama ósea en la zona afectada y en el hueso sano que la rodea.

En la Figura 30 podemos ver un ejemplo de las ortopantomografias de los pacientes ICM y MCM, indicando la zona afectada por el quiste mandibular.

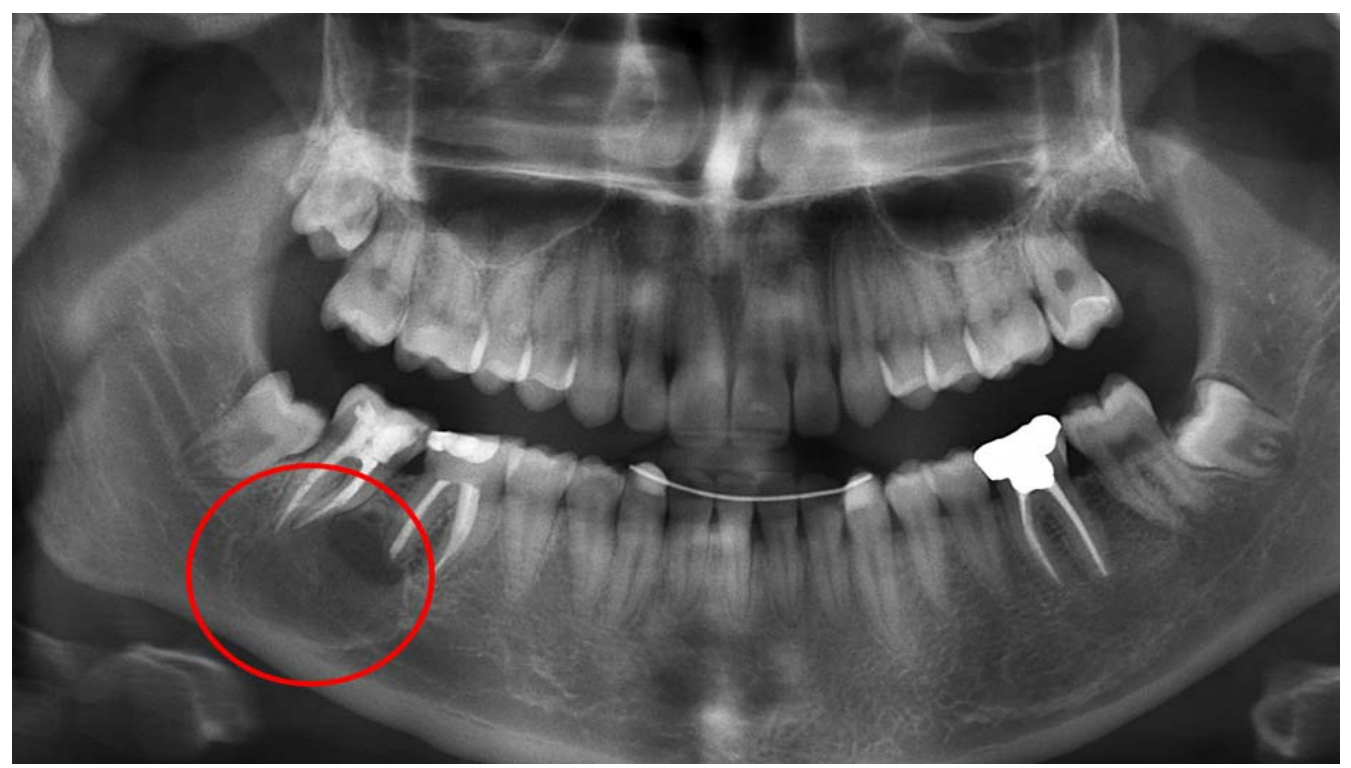

Paciente ICM, localización del quiste maxilar. 


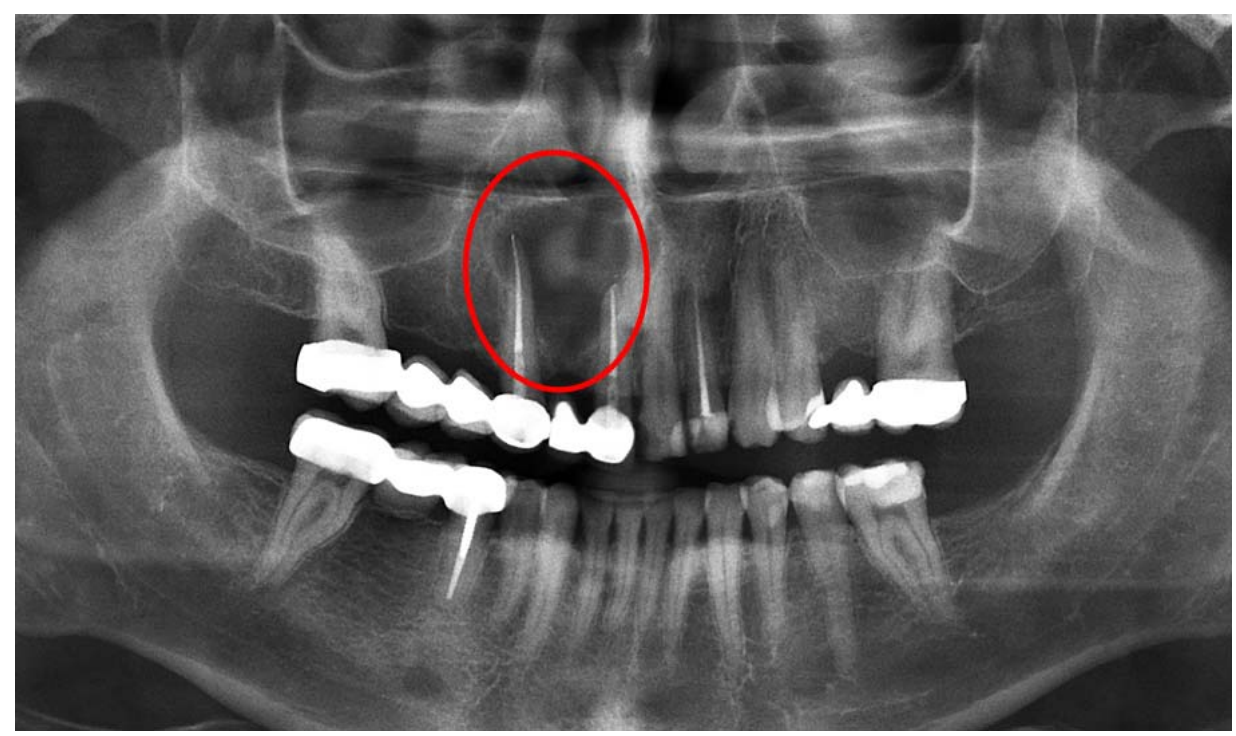

Paciente MCM, localización del quiste maxilar.

Figura 30. Imágenes de ortopantomografias inicio del EC.

\section{EXTRACCIÓN DE MUESTRAS}

A todos los pacientes incluidos en el EC se les extrajo una muestra de hueso esponjoso mandibular y una muestra de sangre. La extracción de las muestras se realizó en el HURH de Valladolid por personal cualificado.

La muestra de sangre se utilizó para la fabricación de la matriz tridimensional, para realizar una serología (HIV 1 y 2, Hepatitis B, Hepatitis C y Lues), y para guardar una muestra de custodia de suero (seroteca) según el Real Decreto-ley 9/2014 en el Centro de Hemoterapia y Hemodonación de Castilla y León (CHEMCYL).

El tamaño de las muestras de hueso y el volumen de sangre extraído a los pacientes se muestra en la Tabla 9. Al paciente número LRC sólo de le extrajo una muestra de $10 \mathrm{ml}$ de sangre para seroteca, porque la muestra de hueso esponjoso estaba contaminada y se abortó la fabricación de la matriz tridimensional. 
Tabla 9. Muestras obtenidas de los pacientes

\begin{tabular}{|c|c|c|}
\hline PACIENTE & $\begin{array}{c}\text { Tamaño } \\
\text { muestra ósea }\end{array}$ & $\begin{array}{c}\text { Volumen } \\
\text { sangre }\end{array}$ \\
\hline LRC $^{*}$ & $3 \mathrm{~mm}$ & $10 \mathrm{ml}$ \\
\hline AAMP & $3 \mathrm{~mm}$ & $40 \mathrm{ml}$ \\
\hline ICM & $5 \mathrm{~mm}$ & $40 \mathrm{ml}$ \\
\hline GOC & $2 \mathrm{~mm}$ & $40 \mathrm{ml}$ \\
\hline MMS & $4 \mathrm{~mm}$ & $40 \mathrm{ml}$ \\
\hline MTSB & $3 \mathrm{~mm}$ & $30 \mathrm{ml}$ \\
\hline VSJA & $3 \mathrm{~mm}$ & $30 \mathrm{ml}$ \\
\hline MCM & $2 \mathrm{~mm}$ & $30 \mathrm{ml}$ \\
\hline MGGB & $2 \mathrm{~mm}$ & $30 \mathrm{ml}$ \\
\hline CCG & $2 \mathrm{~mm}$ & $30 \mathrm{ml}$ \\
\hline MYJB & $2 \mathrm{~mm}$ & $25 \mathrm{ml}$ \\
\hline
\end{tabular}

*En estos pacientes existió contaminación de la muestra que no pudo erradicarse con la cuarentena, por lo que no se completó el tratamiento (ver texto).

\section{PREPARACIÓN DE LAS CÉLULAS MESENQUIMALES DE HUESO (MSV-H).}

Todas las muestras extraídas a los pacientes se transportaron a la UPC refrigeradas $\left(4-12^{\circ} \mathrm{C}\right)$ en un contenedor de poliestireno expandido y junto a un registrador de temperatura (data-logger). A su llegada a la UPC se mantuvieron a $4^{\circ} \mathrm{C}$ hasta su procesamiento.

\subsection{Cultivo de explantes}

Las muestras de hueso esponjoso se procesaron en la UPC y se cultivaron como explantes. A los 4-5 días de iniciarse el cultivo, se podía observar el crecimiento a partir de los explantes de células de aspecto fibroblástico adheridas al frasco de cultivo, como se puede ver en la Figura 31.

El cultivo de la muestra de hueso mandibular presentó frecuentes problemas en cuanto a la contaminación inicial. En el control de calidad realizado en el medio de recogida de las muestras de hueso esponjoso se obtuvo crecimiento bacteriano en 9 de las 11 muestras analizadas. En 6 se detectó crecimiento de microorganismos anaerobios, en 1 crecimiento de microorganismos aerobios y en 2 crecimiento de 
ambos, aerobios y anaerobios. Esto sucede a pesar de que el medio de recogida de muestras tiene un coctel de antibióticos con penicilina $(100 \mathrm{U} / \mathrm{ml})$, estreptomicina $(100 \mu \mathrm{g} / \mathrm{ml})$, y anfotericina A $(0.25 \mu \mathrm{g} / \mathrm{ml})$.

Con objeto de intentar recuperar las muestras, se estipuló un periodo de cuarentena de una semana con medio de cultivo con antibióticos (1\% P/E), cambiando el medio cada 48 horas. Con este protocolo se consiguió crecimiento celular en 9 de los 11 pacientes. Los tests microbiológicos y micológicos al final del periodo de cultivo fueron negativos, indicando que la contaminación había sido erradicada.

Los pacientes abortados por contaminación en los que no fue posible administrar el tratamiento fueron los pacientes LRC y VSJA; por lo que no presentan expansión celular ni producción de matriz tridimensional.
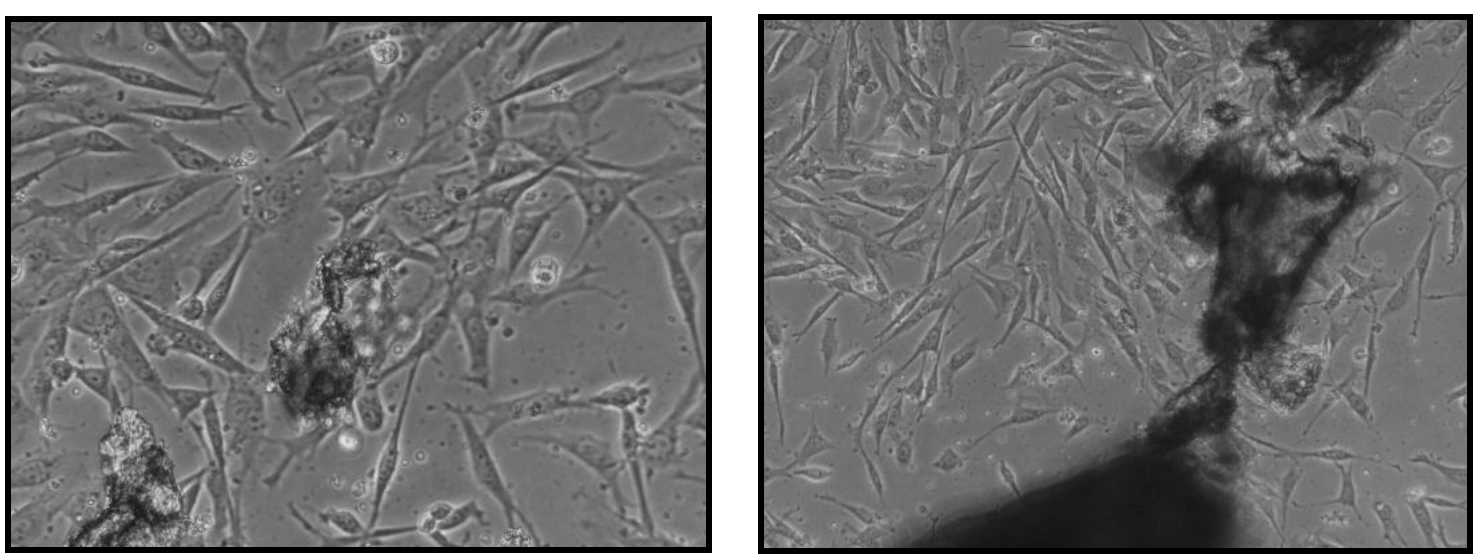

Figura 31. Crecimiento de células a partir de los explantes de hueso esponjoso.

Se aprecia la imagen de células de aspecto fibroblástico que salen a partir del explante y están adheridas al frasco de cultivo.

\subsection{Cultivo y proliferación de las células MSV-H.}

Las células obtenidas de los explantes se mantuvieron en cultivo a $37^{\circ} \mathrm{C}$ y $5 \%$ de $\mathrm{CO}_{2}$ cambiando el medio de cultivo dos veces por semana. Se realizaron entre dos y tres pases hasta obtener las células necesarias para el cultivo de los bioimplantes, aproximadamente 25-30 días de cultivo.

El número de células obtenido en cada paciente y en cada pase se muestra en la Tabla 10. 
Tabla 10. Células MSV-H obtenidas de los pacientes

\begin{tabular}{|c|c|c|c|c|c|c|c|c|}
\hline \multirow{3}{*}{ PACIENTE } & \multicolumn{8}{|c|}{ Células MSV-H } \\
\hline & \multicolumn{2}{|c|}{ Pase 0} & \multicolumn{2}{|c|}{ Pase 1} & \multicolumn{2}{|c|}{ Pase 2} & \multicolumn{2}{|c|}{ Pase 3} \\
\hline & NPcélulas & Viabilidad & Nocélulas & Viabilidad & Nocélulas & Viabilidad & Nocélulas & Viabilidad \\
\hline AAMP & 360.000 & $98 \%$ & 980.000 & $98 \%$ & $4.48 \times 10^{6}$ & $97 \%$ & $37.6 \times 10^{6}$ & $95 \%$ \\
\hline ICM & 600.000 & $97 \%$ & $6.36 \times 10^{6}$ & $94 \%$ & $40.8 \times 10^{6}$ & $96 \%$ & & \\
\hline GOC & 340.000 & $99 \%$ & $1.75 \times 10^{6}$ & $100 \%$ & $4.2 \times 10^{6}$ & $100 \%$ & $20.4 \times 10^{6}$ & $99 \%$ \\
\hline MMS & $1.15 \times 10^{6}$ & $100 \%$ & $6.13 \times 10^{6}$ & $99 \%$ & $39.3 \times 10^{6}$ & $97 \%$ & & \\
\hline MTSB & 180.000 & $100 \%$ & 880.000 & $98.5 \%$ & $4.53 \times 10^{6}$ & $100 \%$ & $30.6 \times 10^{6}$ & $98.5 \%$ \\
\hline MCM & 195.000 & $97.5 \%$ & $1.5 \times 10^{6}$ & $100 \%$ & $6.5 \times 10^{6}$ & $97.5 \%$ & $30.3 \times 10^{6}$ & $98 \%$ \\
\hline MGGB & 360.000 & $99 \%$ & $3.5 \times 10^{6}$ & $100 \%$ & $20.8 \times 10^{6}$ & $100 \%$ & & \\
\hline CCG & 625.000 & $99 \%$ & $3.6 \times 10^{6}$ & $100 \%$ & $42.45 \times 10^{6}$ & $98 \%$ & & \\
\hline MYJB & 540.000 & $100 \%$ & $3.7 \times 10^{6}$ & $100 \%$ & $33.6 \times 10^{6}$ & $100 \%$ & & \\
\hline
\end{tabular}

\subsection{Análisis fenotípico células MSV-H por citometría de flujo}

Las células MSV-H obtenidas a partir del cultivo de explantes se analizaron mediante citometría de flujo para ver si presentaban un fenotipo característico de célula mesenquimal, con un marcaje positivo para los anticuerpos CD73, CD90, CD105 y CD166 y negativo para los marcadores hematopoyéticos como CD34, CD45, el marcador monicitario CD14 y tampoco expresan HLA-DR. Los resultados del análisis fenotípico se muestran en histogramas donde se compara el marcaje con el anticuerpo (histograma azul) con su respectivo control (histograma amarillo).

En la Figura 32 se muestra dos análisis representativos realizados con las células MSV-H de los pacientes MGGB y MYJB. 


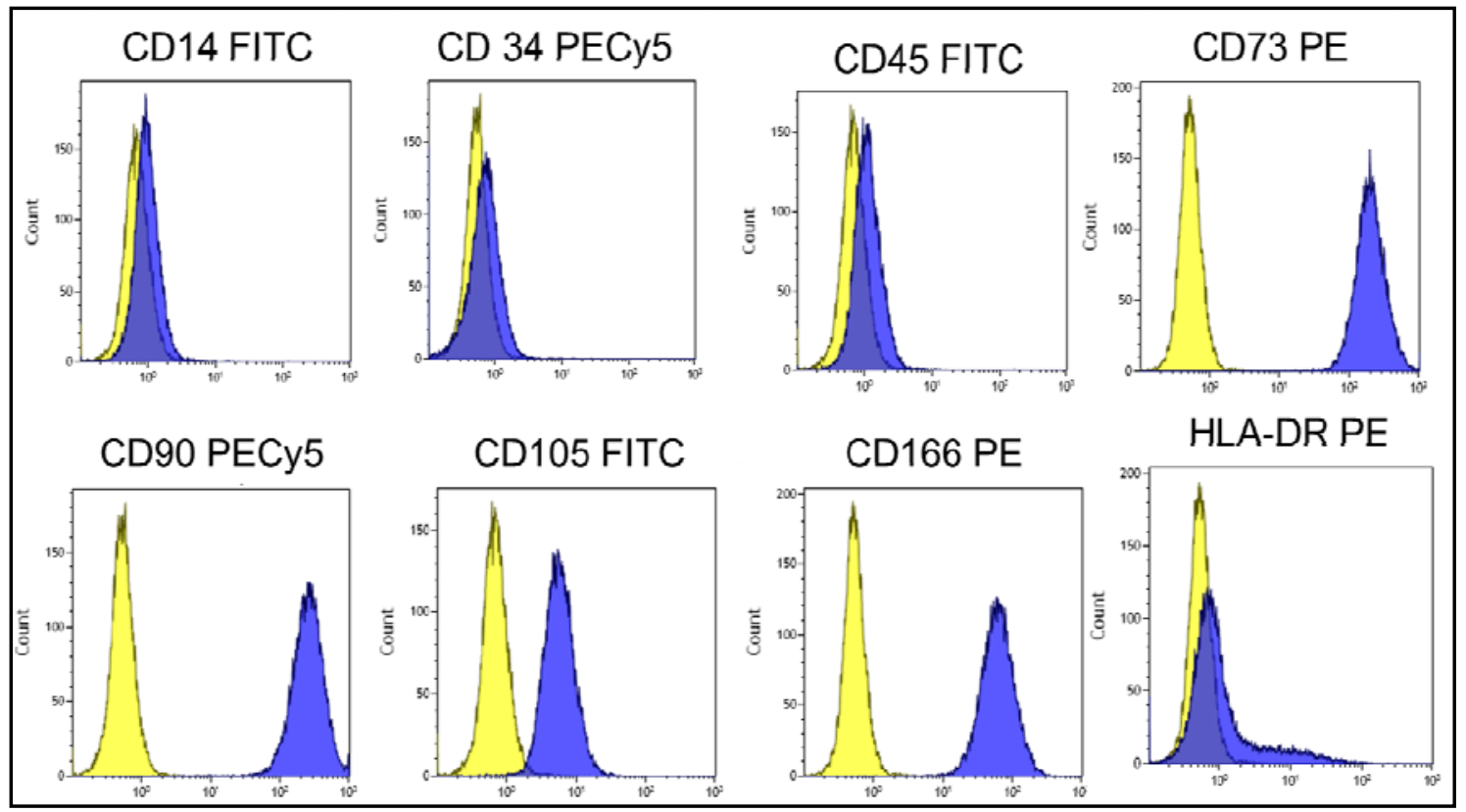

Análisis fenotípico paciente MGGB

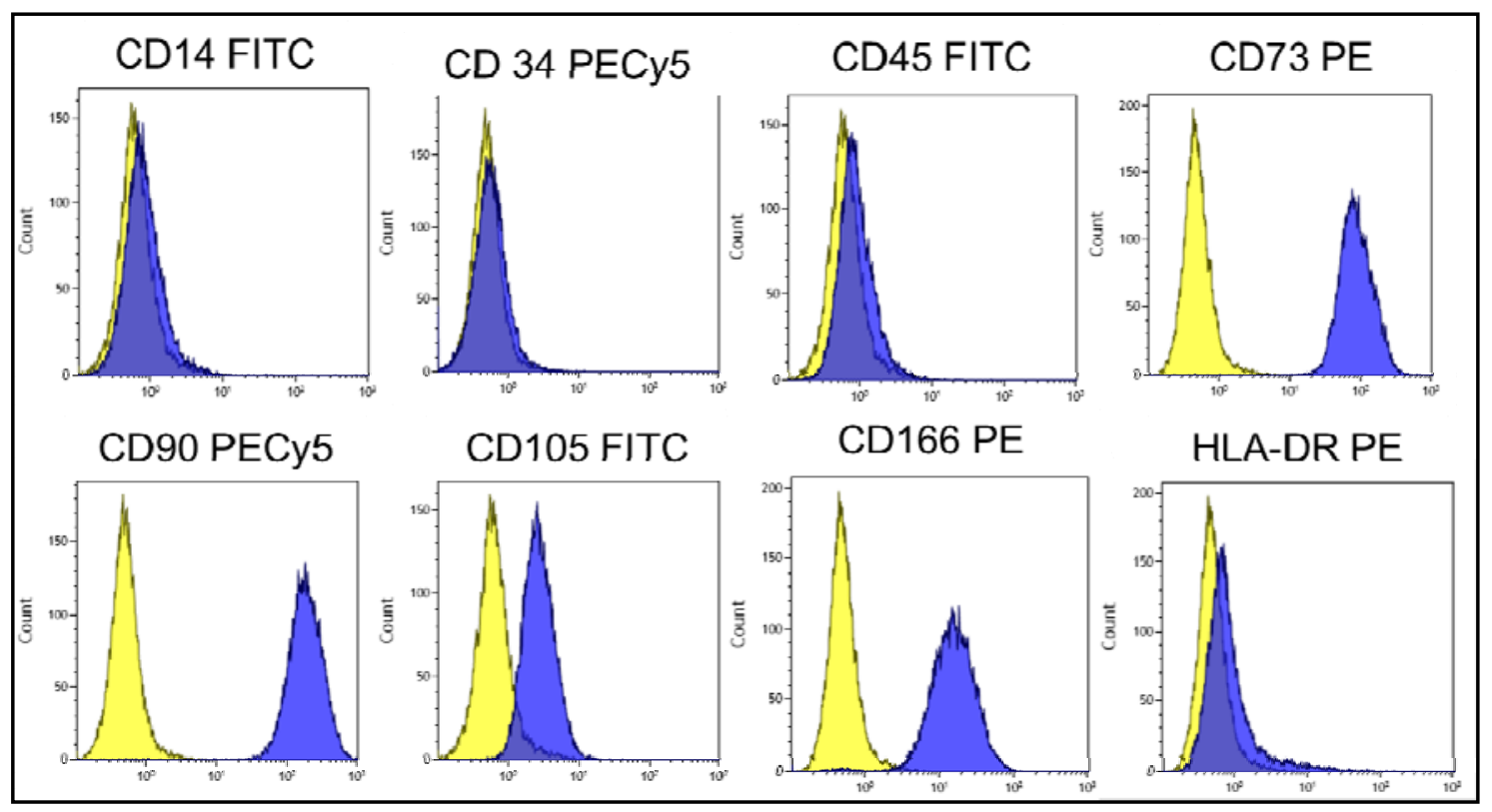

Análisis fenotípico paciente MYJB

Figura 32. Análisis fenotípico por citometría de flujo. 


\section{OBTENCIÓN DE LA MATRIZ TRIDIMENSIONAL}

A partir del entrecruzamiento del suero de los pacientes con glutaraldehído (concentración final 1,25\%) y tras un proceso de congelación, liofilización e hidratación, se obtiene una matriz tridimensional porosa (ver detalles en Materiales y Métodos). En este EC se han realizado discos de matriz de $2 \mathrm{~cm}$ de diámetro por $0.3 \mathrm{~cm}$ de grosor. La Figura 33 muestra la imagen de microscopia electrónica de barrido de un disco de matriz.

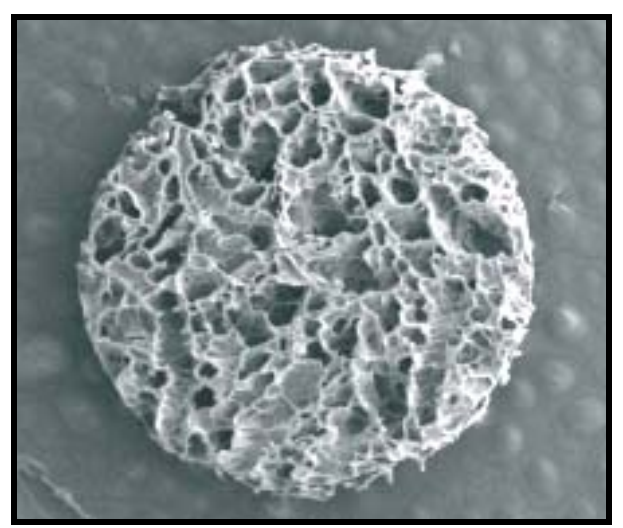

Figura 33. Imagen de un disco de matriz

La Tabla 11 muestra el volumen de suero autólogo de cada paciente y el número de discos obtenidos de matriz.

Tabla 11. Volumen suero y $n^{\circ}$ de discos de matriz por paciente.

\begin{tabular}{|c|c|c|}
\hline PACIENTE & $\begin{array}{c}\text { Volumen } \\
\text { suero }\end{array}$ & $\begin{array}{c}\mathbf{N}^{\circ} \text { discos } \\
\text { de matriz }\end{array}$ \\
\hline AAMP & $10 \mathrm{ml}$ & 4 \\
\hline ICM & $11 \mathrm{ml}$ & 5 \\
\hline GOC & $10 \mathrm{ml}$ & 3 \\
\hline MMS & $20 \mathrm{ml}$ & 4 \\
\hline MTSB & $10.5 \mathrm{ml}$ & 5 \\
\hline MCM & $7.6 \mathrm{ml}$ & 2 \\
\hline MGGB & $11 \mathrm{ml}$ & 4 \\
\hline CCG & $10.5 \mathrm{ml}$ & 5 \\
\hline MYJB & $8 \mathrm{ml}$ & 3 \\
\hline
\end{tabular}




\section{FABRICACIÓN DEL BIOIMPLANTE “BIOMAX”}

Las células MSV-H, una vez expandidas, se sembraron en los discos de matriz formando los bioimplantes "Biomax" que se mantuvieron durante 21-30 días en medio de diferenciación osteogénico antes de ser injertados como material de relleno en el defecto quístico mandibular.

La Tabla 12 resume los datos del tratamiento realizado a cada paciente: número de bioimplantes, número de células por bioimplante, y pase en el que se encontraban las células MSV-H antes de ser sembradas en el matriz.

La Figura 34 muestra las imágenes de microscopio de contraste de fases de dos ejemplos de bioimplantes en cultivo (pacientes AAM y MMS).

Tabla 12. Detalles de los tratamientos realizados a cada uno de los pacientes

\begin{tabular}{|c|c|c|c|}
\hline PACIENTE & $\begin{array}{c}\mathbf{N}^{\circ} \\
\text { bioimplantes }\end{array}$ & $\begin{array}{l}N^{0} \text { células/ } \\
\text { bioimplante }\end{array}$ & $\begin{array}{l}\text { Pase } \\
\text { celular }\end{array}$ \\
\hline AAMP & 3 & 10,0 millones & P3 \\
\hline $\mathrm{ICM}$ & 4 & 10,0 millones & P2 \\
\hline GOC & 3 & 6,6 millones & P3 \\
\hline MMS & 3 & 9,7 millones & P2 \\
\hline MTSB & 3 & 10,0 millones & P3 \\
\hline MCM & 2 & 10,0 millones & P3 \\
\hline MGGB & 3 & 6,6 millones & P2 \\
\hline CCG & 3 & 10,0 millones & P2 \\
\hline MYJB & 3 & 10,0 millones & P2 \\
\hline
\end{tabular}

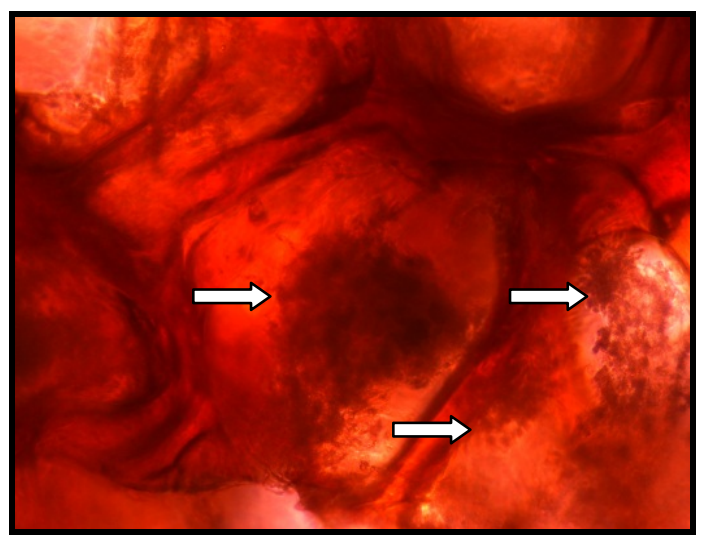

Bioimplante paciente AAM en cultivo

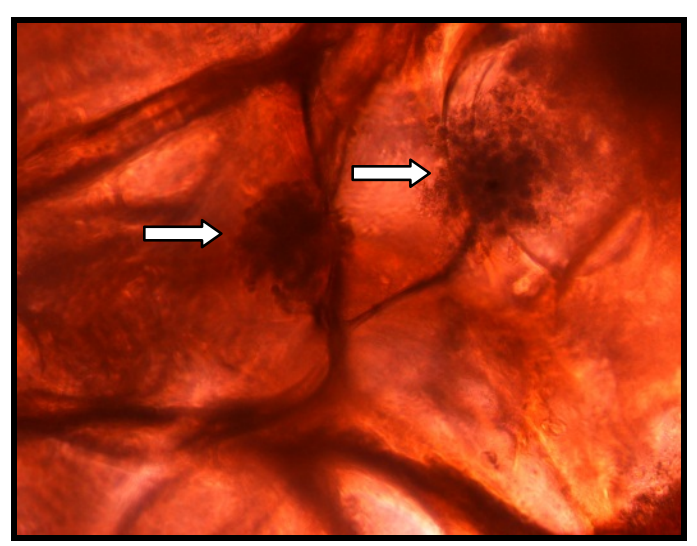

Bioimplante paciente MMS en cultivo

Figura 34. Bioimplantes en cultivo $10 X$

Las flechas señalan grupos células MSV-H en el interior de la matriz. 


\section{CONTROL DE DIFERENCIACIÓN CÉLULAS MSV-H}

Paralelamente al cultivo de los bioimplantes, se realizó otro cultivo de células MSV$\mathrm{H}$ con el mismo medio osteogénico, para comprobar si las células mesenquimales sembradas en la matriz se diferenciaban hacia el linaje osteoblastico y empezaban a sintetizar matriz extracelular. Esto se comprobó mediante una tinción con fosfatasa alcalina (FA). Todos los cultivos realizados de MSV-H con medio ontogénico presentaron expresión de fosfatasa alcalina, como se puede ver en la Figura 35, donde vemos un ejemplo con las tinciones de los pacientes CCG y MTBS que muestran las células positivas para FA teñidas de color rojo.

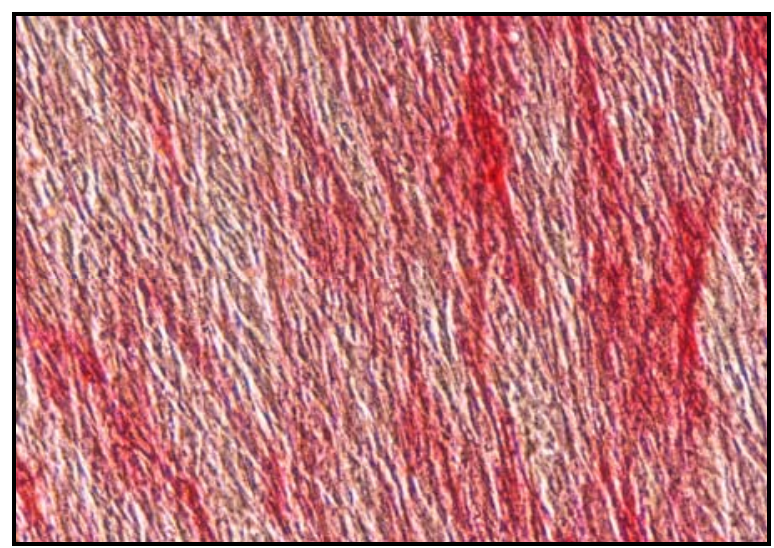

Paciente ICM (10x)

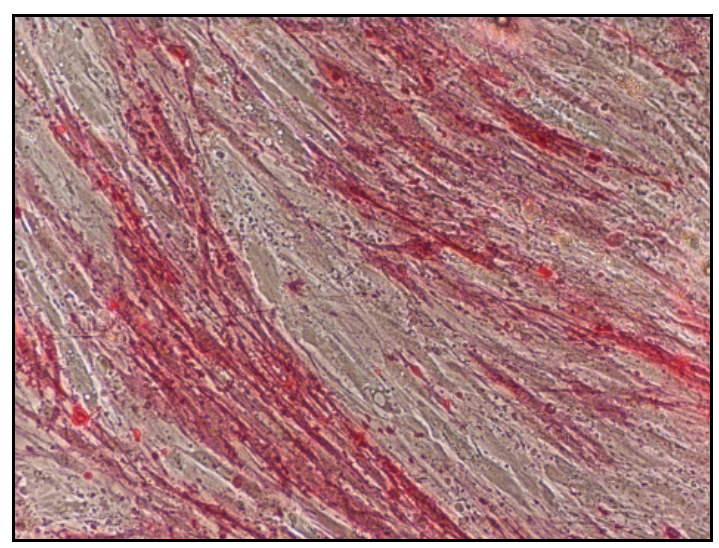

Paciente MTSB (5x)

Figura 35. Tinción de Fosfatasa Alcalina

\section{ANÁLISIS DE RESULTADOS}

\subsection{Efectos adversos}

Según la Organización Mundial de la Salud (OMS) una Reacción Adversa a Medicamentos (RAM) es «cualquier reacción nociva no intencionada que aparece a dosis normalmente usadas en el ser humano para profilaxis, diagnóstico o tratamiento o para modificar funciones fisiológicas». 
Los pacientes tratados con el bioimplante Biomax llevaron un seguimiento durante la totalidad del ensayo, con tres visitas tras la aplicación del tratamiento; una a las dos semanas en la que se retira la sutura y se comprueba el aspecto de la zona injertada. En esta primera visita no se han apreciado signos de reacción inflamatoria ni de rechazo en ninguno de los pacientes.

Las siguientes visitas se fueron a los 3 y 6 meses, en las que se realizó una ortopantomografía para evaluar la eficacia del bioimplante. En esta ocasión, tampoco se observaron signos de reacción inflamatoria ni de rechazo en los pacientes tratados.

\subsection{Análisis de las imágenes de TC.}

Las imágenes DICON obtenidas mediante el estudio de TC fueron analizadas con el software Osirix ${ }^{\circ}$, que nos permite calcular el promedio de la densidad ósea radiológica en unidades Hounsfield en la zona del defecto tratado. Se realizaron mediciones de densidad ósea en un área de $22,2 \mathrm{~mm}^{2}$ en tres planos distintos ( $A, B$ y $C$, separados por $1 \mathrm{~mm}$ ) del eje $Z$ para minimizar el error de medición y se ha utilizado para los análisis el promedio de estos tres valores.

Se muestra un ejemplo en la Figura 36 de las imágenes correspondientes al plano $B$ del paciente CCG en la exploración realizada antes del tratamiento. En el panel a se muestra la imagen en escala de grises y en el panel b la misma imagen codificada en pseudo-color, donde resulta más fácil distinguir las diferencias de densidad. En el lado izquierdo puede distinguirse el quiste, con muy baja densidad ósea, codificada en color azul oscuro y separado del resto del hueso por una zona de densidad intermedia (color verde-amarillo).

El círculo amarillo en el centro del quiste, corresponde a la región de interés evaluada de 22,2 $\mathrm{mm}^{2}$ que se utilizó para realizar las medidas digitales de densidad (en este caso 62). En el lado derecho, se eligió una zona control de hueso esponjoso con densidad relativamente baja, en la que se realizó la medición en una región de interés idéntica, de 22,2 $\mathrm{mm}^{2}$ (la medida en este caso fue de 87 ). 
En la Figura 37 se ilustra cómo se hace la cuantificación con el ejemplo del paciente GOC. El quiste en este caso estaba situado en el lado derecho, y el hueso reticular control en el lado izquierdo (a, b, c y d). Las regiones de interés en las que se realizaron las medidas son los círculos amarillos y corresponden a 22,2 $\mathrm{mm}^{2}$ en ambos casos. Los valores obtenidos en este caso fueron (postratamiento/pretratamiento): 130/43 (cociente, 3,02) en la condición experimental, y 316/214 (cociente, 1,48) en la condición control. En el panel e se muestra en mayor detalle la evolución de las regiones de interés con el tratamiento y puede apreciarse claramente crecimiento de hueso en la zona del quiste, evidenciado por zonas de alta densidad (verde, amarillo y rojo), que rellenan ahora parte de la cavidad quística (Fig. 36e). El efecto es especialmente notable en los bordes del quiste.

La Figura 38 muestra otro ejemplo de la comparación de densidades en escala de grises del pacientel ICM.

\subsection{Cuantificación digital de las imágenes de TC}

Utilizando el procedimiento descrito en el apartado anterior, se cuantificaron los 9 pacientes tratados, eligiendo la zona experimental (quiste; tratado) y control (hueso reticular; no tratado) en cada paciente y cuantificando tres planos del eje $Z, A, B$ y $C$, en cada región de interés. Los valores originales se muestran en las Tablas 13A (experimental) y $13 \mathrm{~B}$ (control). Los valores promedios ( $\pm \mathrm{DS})$ se recogen en la Tabla 14, para mostrar que la dispersión fue razonablemente pequeña, especialmente en el caso de los datos del grupo experimental, que son los que más nos importan a efectos de comparaciones. 

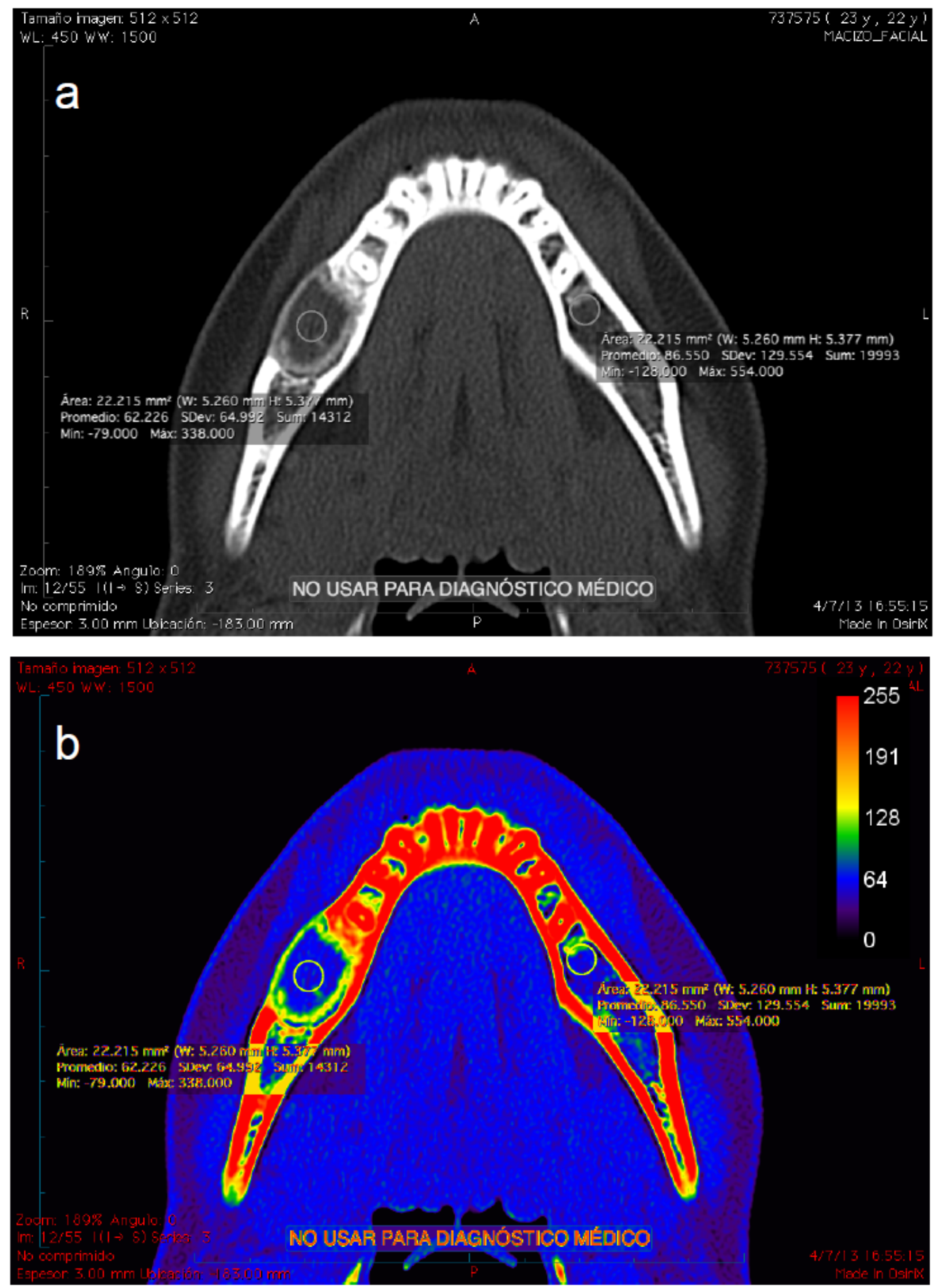

Figura. 36. Medidas de densidad ósea por TC previo al tratamiento del paciente CCG. Arriba, imagen en escala de grises, abajo, la misma en pseudo-color (escala arriba a la derecha). Se ilustran las medidas en una región de interés circular de $22,2 \mathrm{~mm}^{2}$ en el quiste (lado izquierdo) y en una zona de hueso esponjoso control en el lado derecho. 

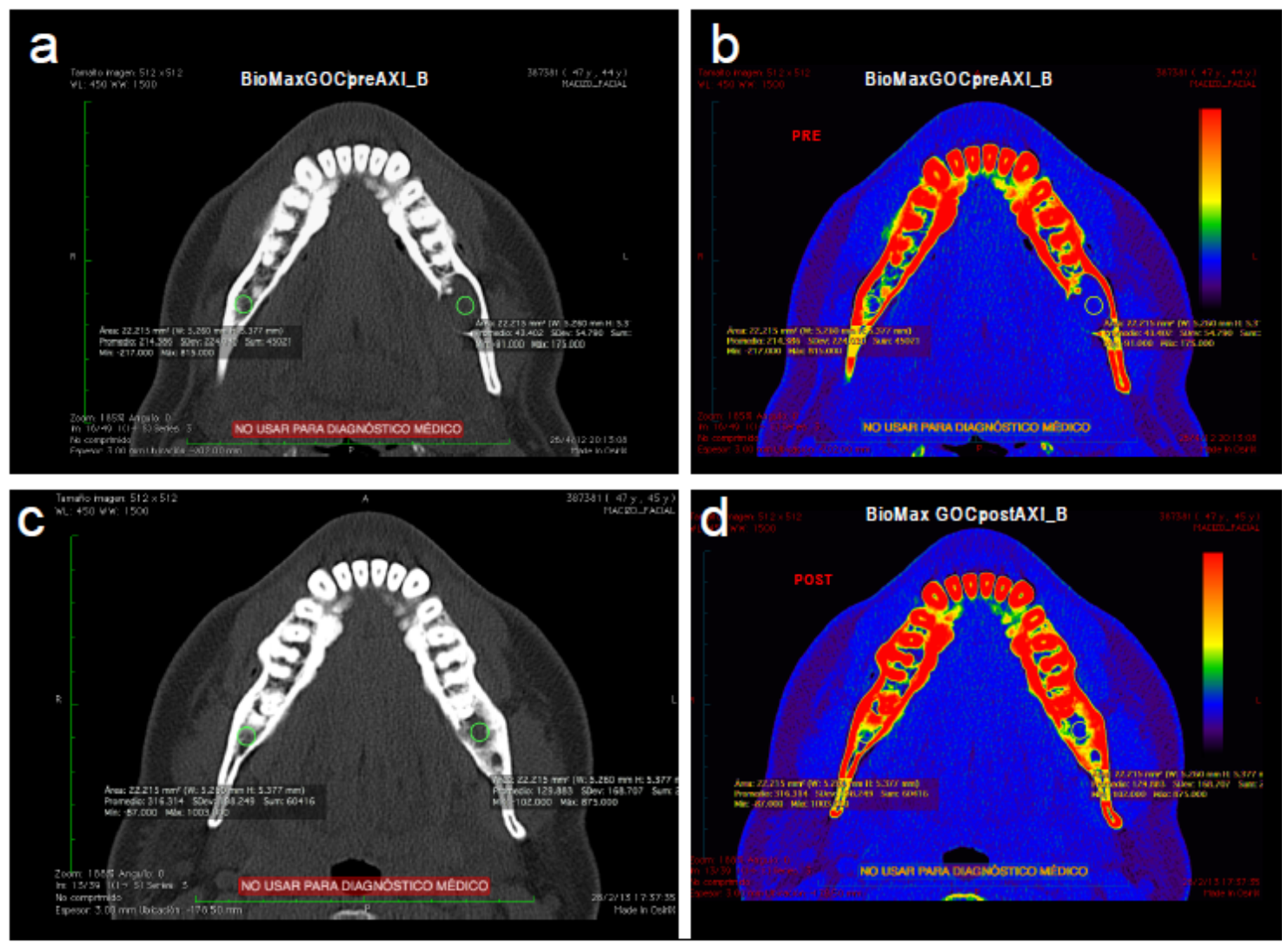

\section{e. Comparación de densidades antes y después del tratamiento.}
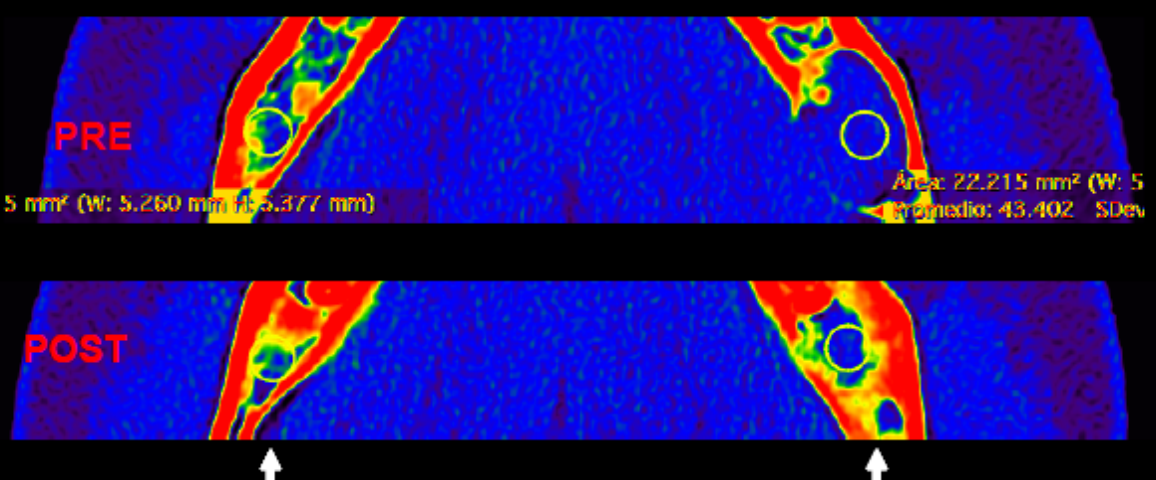

CONTROL

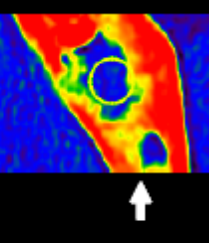

QUISTE

Figura. 37. Medidas de la densidad ósea en las imágenes de TC del paciente GOC antes (a y b) y después del tratamiento (c y d). A la izquierda, imágenes en gris (a y c), a la derecha las mismas imágenes en falso color (b y d). Todas las imágenes corresponden al plano axial (B). El quiste está en este caso situado a la derecha y el hueso reticular control a la izquierda. Las regiones de interés en las que se realizaron las medidas son los círculos amarillos y corresponden a 22,2 $\mathrm{mm}^{2}$. Los valores obtenidos en este caso fueron (pretratamiento/postratamiento): en la condición experimental, 43/129, y en la condición control, 214/316. En el panel e se muestra en mayor detalle la evolución de las regiones de interés con el tratamiento. 

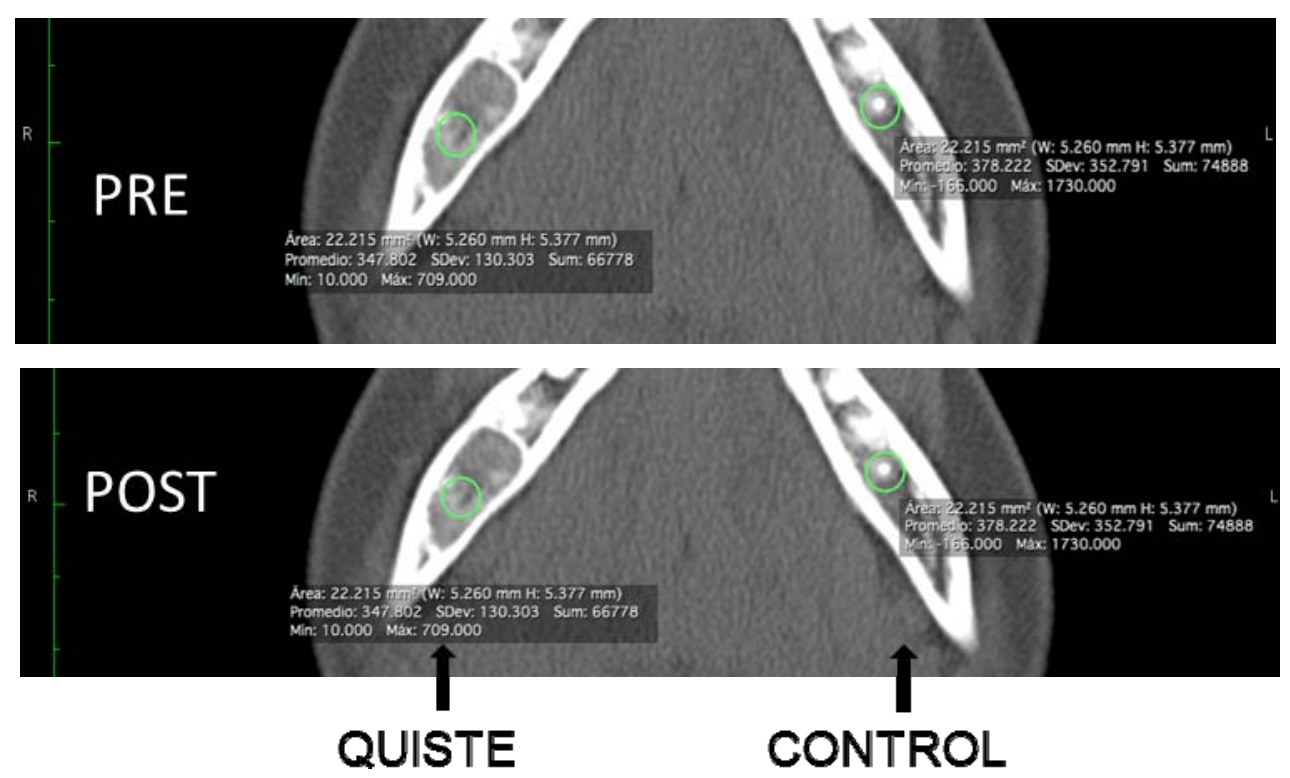

Figura. 38. Comparación de densidades antes y después del tratamiento en escala de grises. Arriba imágenes del paciente ICM y abajo imágenes correspondientes al paciente AMP.

Tabla 13A. Mediciones en la zona de hueso experimental (defecto)

\begin{tabular}{|c|c|c|c|c|c|c|c|}
\hline & \multicolumn{3}{|c|}{$\begin{array}{c}\text { MEDIDAS } \\
\text { PREOPERACION }\end{array}$} & \multicolumn{3}{|c|}{$\begin{array}{c}\text { MEDIDAS } \\
\text { POSTOPERACION }\end{array}$} \\
\hline & & A & B & C & $\mathbf{A}$ & B & C \\
\hline \multirow{9}{*}{ 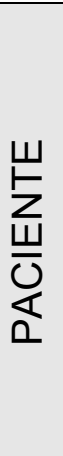 } & AMP & 57 & 64 & 89 & 107 & 82 & 180 \\
\hline & CCG & 58 & 62 & 67 & 252 & 197 & 201 \\
\hline & GOC & 57 & 43 & 81 & 154 & 130 & 153 \\
\hline & ICM & 335 & 406 & 326 & 348 & 407 & 356 \\
\hline & MCM & 38 & 37 & 41 & 52 & 104 & 140 \\
\hline & MGGB & 31 & 26 & 43 & 319 & 164 & 108 \\
\hline & MMS & 164 & 165 & 163 & 183 & 214 & 212 \\
\hline & MTSB & 52 & 43 & 58 & 72 & 136 & 107 \\
\hline & MYJB & 65 & 95 & 60 & 139 & 180 & 365 \\
\hline
\end{tabular}


Tabla 13B. Mediciones en la zona de hueso control

\begin{tabular}{|c|c|c|c|c|c|c|c|}
\hline & \multicolumn{3}{|c|}{$\begin{array}{c}\text { MEDIDAS } \\
\text { PREOPERACION }\end{array}$} & \multicolumn{3}{|c|}{$\begin{array}{c}\text { MEDIDAS } \\
\text { POSTOPERACION }\end{array}$} \\
\hline & & A & B & C & $A$ & B & C \\
\hline \multirow{9}{*}{ 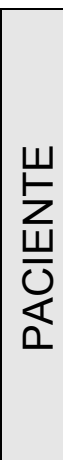 } & AMP & 354 & 446 & 305 & 356 & 147 & 217 \\
\hline & CCG & 136 & 87 & 373 & 310 & 240 & 452 \\
\hline & GOC & 151 & 214 & 182 & 194 & 316 & 223 \\
\hline & $\mathrm{ICM}$ & 394 & 1161 & 250 & 378 & 491 & 268 \\
\hline & MCM & 420 & 500 & 620 & 156 & 516 & 574 \\
\hline & MGGB & 283 & 375 & 371 & 334 & 239 & 314 \\
\hline & MMS & 1361 & 1276 & 1327 & 879 & 722 & 1039 \\
\hline & MTSB & 255 & 224 & 307 & 245 & 276 & 297 \\
\hline & MYJB & 690 & 647 & 685 & 559 & 700 & 648 \\
\hline
\end{tabular}

Tabla 14. Medias y DS de las Densidades óseas

\begin{tabular}{|c|c|c|c|c|c|}
\hline & \multicolumn{4}{|c|}{ Valores (Media $\pm D S ; n=3$ ) } \\
\hline & & \multicolumn{2}{|c|}{ Hueso Experimental } & \multicolumn{2}{|c|}{ Hueso Control } \\
\hline & & PRE & POST & PRE & POST \\
\hline \multirow{9}{*}{ 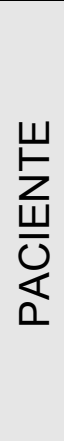 } & AMP & $70 \pm 17$ & $123 \pm 51$ & $368 \pm 72$ & $240 \pm 106$ \\
\hline & CCG & $62 \pm 4$ & $217 \pm 31$ & $198 \pm 153$ & $334 \pm 108$ \\
\hline & GOC & $60 \pm 19$ & $146 \pm 14$ & $182 \pm 32$ & $245 \pm 64$ \\
\hline & $\mathrm{ICM}$ & $356 \pm 44$ & $370 \pm 32$ & $602 \pm 490$ & $379 \pm 112$ \\
\hline & $\mathrm{MCM}$ & $39 \pm 2$ & $99 \pm 44$ & $513 \pm 101$ & $415 \pm 227$ \\
\hline & MGGB & $33 \pm 8$ & $197 \pm 109$ & $343 \pm 52$ & $296 \pm 50$ \\
\hline & MMS & $164 \pm 1$ & $203 \pm 17$ & $1321 \pm 43$ & $880 \pm 159$ \\
\hline & MTSB & $51 \pm 7$ & $105 \pm 32$ & $262 \pm 42$ & $273 \pm 26$ \\
\hline & MYJB & $74 \pm 19$ & $228 \pm 121$ & $674 \pm 24$ & $636 \pm 71$ \\
\hline
\end{tabular}

En la Tabla 15 se reúnen todos los valores pertinentes para el análisis estadístico. Los valores pre- y post-operación son las medias de las tres determinaciones realizadas, mostradas en las tablas anteriores. Se añade además una columna que es el "cociente" del valor obtenido después de la operación dividido por el valor previo. La Tabla resume, por tanto, el comportamiento comparativo del quiste tratado con MSV-H en matriz de suero autólogo con un sector de hueso esponjoso no tratado en el lado contralateral del mismo maxilar. 
En el grupo de datos experimentales, los 9 pacientes tratados con Biomax aumentaron su densidad ósea un año después del tratamiento y los valores medios fueron significativamente mayores que el valor previo al tratamiento $(p<0,004$; Tabla 14). En el caso de los valores control, no hubo diferencias significativas entre los valores al inicio y al final de la intervención.

En la Figura 39 a y b se representan los valores obtenidos antes y después del tratamiento en cada uno de los pacientes en las condiciones control y experimental. Los pacientes por encima de una línea con pendiente de 1, representada a trazos discontinuos en la figura, son los que han mejorado con el tratamiento. Como puede verse, todos los pacientes experimentales mejoraron su densidad ósea (se encuentran por encima de la línea de puntos), mientras que solo se observó aumento de densidad ósea en los valores controles en 3 de los 9 pacientes tratados (Figura 39, a y b)

La evolución de la formación de hueso puede también resumirse en la relación densidad ósea tras el tratamiento/densidad antes del tratamiento ("Cociente" en Tabla 15). Cuando el valor es mayor que 1 indica que ha habido formación de hueso nuevo. Los valores del cociente en los quistes tratados fueron en todos los casos, mayor de 1. El valor promedio de los 9 casos fue de (media \pm ESM) 2,52 \pm 0,45 . Este valor es significativamente mayor que 1 ( $p<0.004$; test de Wilcoxon). En contraste, los controles de evolución de hueso esponjoso en la misma mandíbula no fueron significativamente mayores de 1 (0.99 \pm 0.14 ; Tabla 15).

En la Figura 40 se comparan los valores control y experimental en un diagrama de barras. La comparación directa de ambos valores mostró también diferencias muy significativas ( $p<0.001$; test de Mann-Whitney). 
Tabla 15. Comparación de las densidades en los grupos control y experimental.

\begin{tabular}{|c|c|c|c|c|c|c|}
\hline \multirow[b]{2}{*}{ PACIENTE } & \multicolumn{3}{|c|}{ EXPERIMENTAL } & \multicolumn{3}{|c|}{ CONTROL } \\
\hline & Pre & Post & Cociente & Pre & Post & Cociente \\
\hline AMP & 70 & 123 & 1.70 & 368 & 240 & 0.62 \\
\hline CCG & 62 & 217 & 3.46 & 198 & 334 & 1.97 \\
\hline GOC & 60 & 146 & 2.49 & 182 & 245 & 1.33 \\
\hline ICM & 356 & 370 & 1.04 & 602 & 379 & 0.76 \\
\hline MCM & 39 & 99 & 2.37 & 513 & 415 & 0.71 \\
\hline MGGB & 33 & 197 & 5.43 & 343 & 296 & 0.86 \\
\hline MMS & 164 & 203 & 1.24 & 1321 & 880 & 0.66 \\
\hline MTSB & 51 & 105 & 2.00 & 262 & 273 & 1.05 \\
\hline MYJB & 74 & 228 & 2.90 & 674 & 636 & 0.94 \\
\hline & & & & & & \\
\hline Media & 101 & 187 & 2.52 & 496 & 411 & 0.99 \\
\hline DS & 103 & 84 & 1.34 & 355 & 214 & 0.43 \\
\hline ESM & 34 & 28 & 0.45 & 118 & 71 & 0.14 \\
\hline $\begin{array}{l}\text { Significación } \\
\text { estadítica: }\end{array}$ & & $p<0.004^{*}$ & $p<0.004^{* *}$ & & N.S.* & N.S. ${ }^{* *}$ \\
\hline
\end{tabular}

Notas:

Cada valor es promedio de 3 medidas (1 por $\mathrm{mm}$ ) en un área de $22.2 \mathrm{~mm}^{2}$ Los cocientes se calcularon dividiendio el valor "Post" por el "Pre".

*Comparación Pre vs Post. Test de Wilcoxon (no paramétrico)

**Diferencia del valor 1 , Test de Wilcoxon (signed rank) (no paramétrico) La diferencia entre los valores de ratio de los grupos experimental y control también es significativamente distinta de 0 ( $p<0.001$; test de MannWhitney; no paramétrico) 


\section{A. Experimentales}

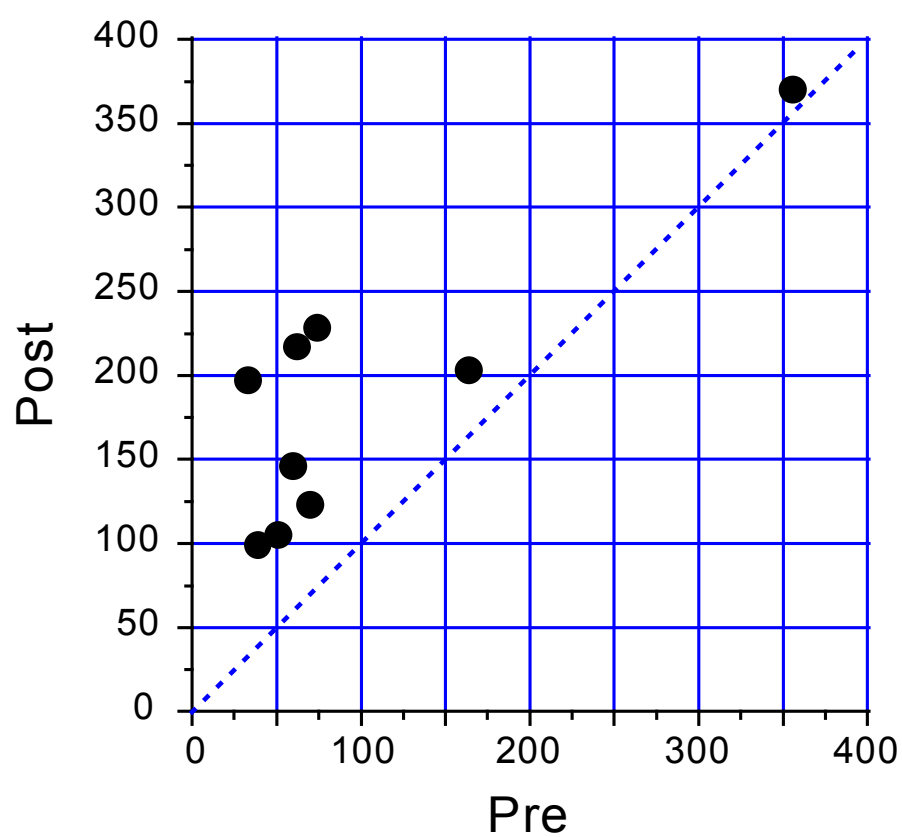

B. Controles

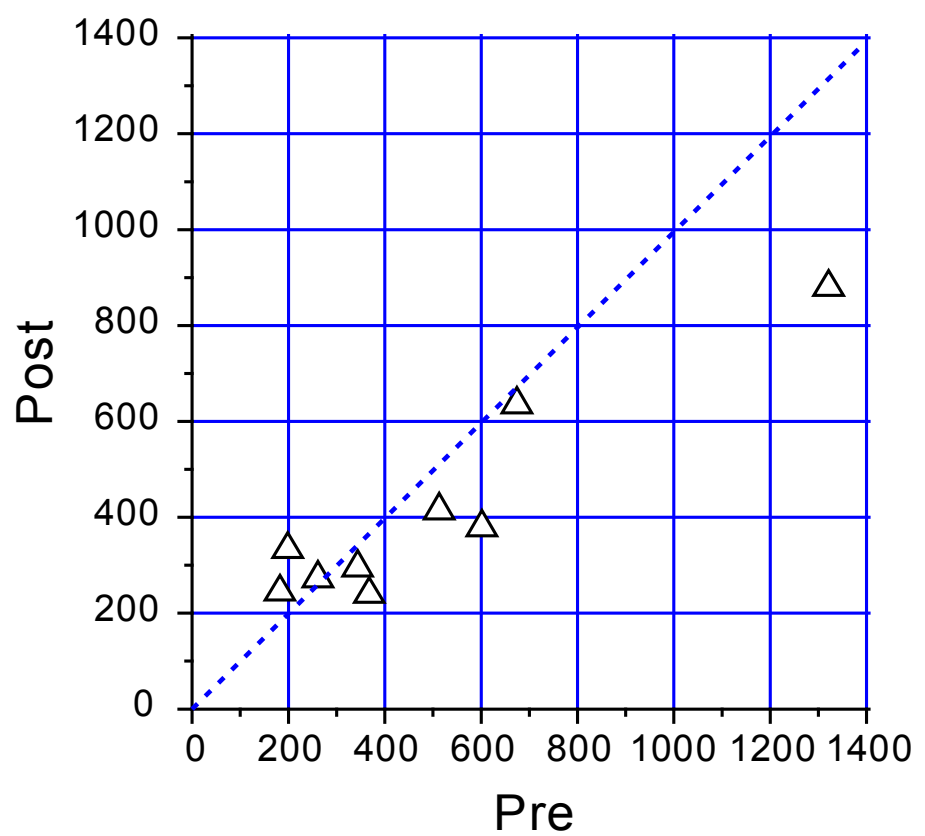

Figura 39. Valores densidad ósea antes y despues del tratamiento.
A. Valores densidad ósea en la zona experimental.

B. Valores densidad ósea en la zona control 


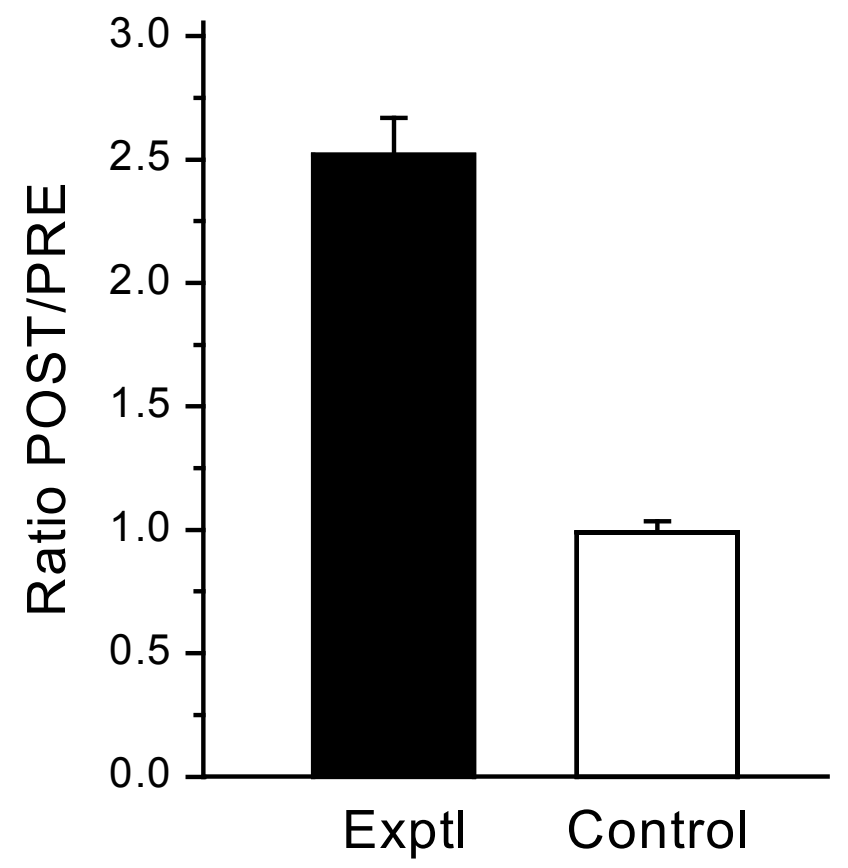

Mean +/- esm

Difference from 1:

$p<0.005$ (Wilcoxon, non-parametric)

Figura 40. Comparacion de los valores (cociente) de densidad ósea en la zona experimental y en la zona control. 
DISCUSIÓN 



\section{DESARROLLO DEL PRODUCTO FARMACEÚTICO BIOIMPLANTE "BIOMAX".}

\subsection{OBTENCION CELULAS MESENQUIMALES DE HUESO (MSV-H)}

La Terapia Celular se ha desarrollado a partir de la década de los 90 con los avances de la biotecnología y los biorreactores, que buscaban aumentar la productividad de los cultivos celulares con una disminución en los costes de producción y sin reducir la calidad de los productos (Trujillo-Roldan y col, 2009). En este momento es cuando se inicia la producción de medicamentos de terapias avanzadas a gran escala. Destaca la utilización de células madre mesenquimales (MSC) por su gran potencial para la reparación de tejidos dañados como hueso, cartílago, tendón y ligamentos (Beyer Nardy y col, 2006) y por su capacidad inmunorreguladora (Uccelli y col, 2006, Patel y col, 2008; Shi y col, 2011). Se ha propuesto la utilización de MSC en mas enfermedades: Parkinson, Alzehimer, lesiones de médula espinal, enfermedades cardiacas, derrames cerebrales, quemaduras y osteoartritis entre otras (Park y col, 2014; Joyce y col, 2010; Kin y col, 2015; Gnecchi y col, 2012; Dulamea, 2015; Koźlik y col, 2014; Orozco y col, 2011; Orozco y col, 2013; Orozco y col, 2014; Vega y col, 2015).

Clásicamente, las MSC se obtenían de médula ósea, pero en la actualidad se extraen de muchos tejidos diferentes como tejido adiposo (Zuk y col, 2002; Wagner y col, 2005), músculos, tendón y diferentes tejidos dentales (Huang y col, 2009; Tran Hle y col, 2014, Alkhalil y col, 2015), sangre del cordón umbilical (Olson y col, 2015), placenta (Sabapathy y col 2012), periostio, tejido cartilaginoso, líquido sinovial, bazo e hígado (Arthur y col, 2009). Incluso de la sangre menstrual y del endometrio decidual (Rossignoli y col, 2013).

Nuestra Unidad de Producción Celular (UPC) está especializada en la fabricación del medicamento de terapia avanzada MSV (mesenquimales de Valladolid), constituido por MSC de médula ósea, autorizadas por la AEMPS para diferentes ensayos clínicos, como el tratamiento de la degeneración del disco intervertebral lumbar y aplicaciones osteoarticulares (Ensayo clínico Eudra-CT: 2005-005498-36. $N^{\circ}$ Eudra CT 2008-001191-68, Eudra № 2009-0170450-11). 
A pesar de nuestra experiencia en el procesamiento de la médula ósea y en la obtención de las MSV a partir de esta, aquí nos hemos planteado obtener el mismo tipo celular, MSV, pero a partir del tejido óseo mandibular.

La dificultad que nos planteó el cambio de tejido fuente, es la falta de experiencia en trabajar con estas muestras en condiciones GMP. Recibimos las muestras en un envase de recogida abierto (tubo falcon) y que procede de un tejido que presenta una elevada carga microbiana como es la cavidad oral, aloja $10^{10}$ bacterias (Linossier y col, 2011). Esta es una gran diferencia respecto a la muestra de médula ósea, que se extrae en condiciones estériles directamente en un sistema de circuito cerrado (bolsa de trasferencia).

Para luchar contra este inconveniente recogemos la muestra de hueso esponjoso en un medio RPMI suplementado con una solución de antibióticos y antimicóticos, y se deja en el mismo hasta su procesamiento (unas $24 \mathrm{~h}$ ). Esto se realiza con el fin de disminuir todo lo posible la carga bacteriana inicial. Un método alternativo para reducir el número de microorganismos en la cavidad oral sería un tratamiento previo con soluciones antisépticas como la clorhexidina. Este compuesto se une a la membrana celular bacteriana, a bajas concentraciones produce un aumento de la permeabilidad con filtración de los componentes intracelulares incluido el potasio, lo que genera un efecto bacteriostático. A concentraciones más altas produce la precipitación del citoplasma bacteriano y la muerte celular, por lo que tiene efecto bactericida (Bascones y col, 2006). Sin embargo, la utilización de los colutorios antisépticos sólo reduce la carga bacteriana en un $44 \%$, y esto si se acompaña de métodos mecánicos de higiene oral e interdental (Enrile de Rojas y col, 2005). El método preventivo a seguir para evitar la contaminación de la muestra de hueso esponjoso mandibular, sería un proceso de higiene oral e interdental exhaustivo con métodos mecánicos y un tratamiento posterior con el colutorio. Como sólo es un tratamiento preventivo y no eliminamos la totalidad de la carga bacteriana, no se ha estipulado en nuestro estudio, ya que sólo generaría molestias al paciente.

Pero no todo son inconvenientes. La ventaja de trabajar con muestras de tejido óseo mandibular es que estas se obtienen en la consulta de cirugía maxilofacial bajo anestesia local y sedación mediante una trefina de $2 \mathrm{~mm}$ sin generar grandes 
molestias al paciente (Gallego y col, 2010), a diferencia de la muestra de médula ósea, que se obtiene en un quirófano bajo anestesia local y sedación, mediante punciones repetidas en los huesos planos de la cadera, lo que genera molestias en las zonas de punción. Estas molestias normalmente desaparecen a las 24-48 horas, pero pueden prolongarse durante varios días. Además, estos pacientes pueden sentir sensación de mareo debido a que la extracción de la médula ósea les genera cierto grado de anemia y presentar décimas de fiebre en las primeras horas post-extracción.

En este punto, la utilización de un tejido adulto como es el hueso esponjoso mandibular como tejido fuente, nos permite obtener células MSC con mayor tasa de proliferación y de diferenciación osteogénica que las células obtenidas de la cresta iliaca (Akintoye y col, 2006), y presentan un retraso en la senescencia, expresando niveles elevados de fosfatasa alcalina y demostrando más acumulación de calcio "in Vitro" (Nishimura y col, 2012). Además, las MSC obtenidas a partir de tejidos adultos presentan un mayor potencial para la regeneración de daños musculoesqueléticos (Mafi y col, 2011), y en nuestro caso queremos regenerar defectos óseos.

Actualmente, en función del tejido fuente empleado, se utilizan diferentes técnicas para el aislamiento de las MSC, principalmente gradientes de densidad (Ficoll o Percoll) en médula ósea o sangre menstrual (Rossignoli y col, 2013) o digestiones enzimáticas (tripsina, colagenasa, dispasa) cuando empleamos un tejido, como por ejemplo, el adiposo (Wagner y col, 2005) o la pulpa dental (Alkahalil y col, 2015). Sin embargo, el primer objetivo de este trabajo se centra en obtener MSC a partir de tejido óseo mandibular mediante el cultivo de pequeños fragmentos del mismo que se denominan "explantes", sin la necesidad de procesamientos previos.

La obtención de células humanas a partir de fragmentos de hueso se inició en 1979 por los trabajos realizados por Mills y col, aunque previamente Jones y Boyde habían observado la migración de los osteoblastos desde el hueso a la superficie de cultivo (Jones y col, 1977). Estudios posteriores demostraron que las células que crecían a partir de los fragmentos de hueso presentaban un fenotipo osteoblástico, 
porque presentaban niveles elevados de actividad fosfatasa alcalina y producían osteocalcina (Beresford y col, 1984). Además, estudios comparativos confirmaron que las células de hueso obtenidas a partir de explantes y las obtenidas por digestiones enzimáticas con tripsina y colagenasa, no diferían en cuanto a su fenotipo osteoblástico (Auf'mkolk y col, 1985). Begley col en 1993 realizaban lavados con solución tampón (HBSS) de los fragmentos de hueso para eliminar los restos tejido hematopoyético, grasa y sangre antes de su cultivo, lo que evitaba la contaminación del cultivo por el crecimiento de fibroblastos. Otros grupos empleaban soluciones tampón con antibióticos para evitar al mismo tiempo contaminaciones bacterianas y contaminación de células de los tejidos adyacentes (Meseguer y col, 1994). El siguiente avance en el cultivo de fragmentos de hueso, fue el pretratamiento de los mismos con una solución enzimática que eliminaba todas las células de los explantes excepto las adyacentes al hueso, lo que permitía obtener cultivos de osteoblastos purificados (Robey, 1995). Nosotros, realizamos un pretratamiento de los explantes con tripsina antes de su cultivo, lo que nos permite eliminar todos los restos de sangre y células adheridas a la muestra.

El protocolo del cultivo de explantes con un pretratamiento enzimático nos ha permitido obtener cultivos purificados de células adherentes de aspecto fibroblástico fácilmente y sin la realización de procesos costosos y laboriosos como la obtención de MSC a partir de médula ósea mediante un gradiente de densidad con ficoll.

Antes de iniciar el procesamiento de la muestra, el cumplimiento de la normativa GMP para la fabricación de medicamentos de terapia celular nos lleva a realizar una comprobación del estado de la sala de producción (presiones, temperatura, calibración de equipos,....). Las condiciones de las instalaciones y los equipos, junto con los controles de calidad de ambiente (partículas y sedimentación), de personal (contacto de guantes) y de producto (microorganismos aerobios, anaerobios y micoplasma) realizados en todas las fases del proceso de fabricación, nos permiten garantizar la calidad GMP del producto para su aplicación clínica.

Actualmente, los protocolos de expansión celular para aplicaciones clínicas deben, de acuerdo a las GMP, evitar en lo posible el uso de suero animal por el riesgo que existe de la transmisión de virus y priones. Sin embargo, la mayoría de los ensayos 
clínicos realizados con MSC utilizan protocolos de expansión con medios suplementados con suero bovino fetal (FBS) (Hemeda y col, 2014). El proceso de expansión nos permite aumentar "in Vitro" el reducido número de células que obtenemos del explante de hueso mandibular, en proporciones exponenciales, sin que las células pierdan sus propiedades fisiológicas, bioquímicas y genéticas. Poe este motivo, es muy importante utilizar medios suplementados con los factores de crecimiento adecuados que permitan la multiplicación celular sin comprometer su capacidad de diferenciación. Las opciones que aparecen para sustituir al FBS es utilizar suero humano (HS), plasma rico en plaquetas (PRP) o lisado plaquetario humano (HPL).

Está demostrado que el uso de HS de forma autóloga para la expansión de MSC es factible sin comprometer la capacidad de diferenciación de las células y sin alterar el inmunofenotipo de las mismas (Stute y col, 2004). Sin embargo, la utilización de HS tiene una gran limitación en cuanto al volumen necesario para realizar una expansión celular; ante esta limitación, surge la alternativa de utilizar HS AB alogénico. En este punto, los estudios de Kocaoemer y col (2007) muestran que las MSC derivadas de tejido adiposo muestran una mayor tasa de proliferación en medios suplementados con HS AB que cuando se utiliza FBS.

El PRP es un concentrado de plaquetas que poseen una gran diversidad de factores de crecimiento (TGF- $\beta$, BMP, FGF, IGF y PDGF) y que tienen propiedades inductivas para la regeneración de los tejidos. Sin embargo, los restos celulares que presenta puede alterar el cultivo celular y además necesita la adición de trombina exógena para activar las plaquetas provocando su degranulación, lo que genera la liberación inmediata de los factores de crecimiento al medio de cultivo (González y col, 2012; Hemeda y col, 2014). El PRP preparado por activacion con trombina (tPRP) también presenta una tasa de proliferación mayor que el FBS en MSC derivadas de tejido adiposo (Kocaoemer y col, 2007). Para solucionar los problemas del PRP, debris y activación, este se somete a un proceso de congelación antes de añadirlo al medio. Esto genera la lisis de las plaquetas y la liberación de los factores de crecimiento sin la adición de trombina exógena. Sin embargo, cuando se realiza este proceso, ya no es correcto hablar de PRP ya que sería un lisado plaquetario humano (HPL). 
La primera utilización de HPL para la expansión de MSC fue descrita por Doucet y col en 2005 y actualmente es la mejor elección para la producción de MSC bajo normativa GMP para aplicaciones clínicas. EI HPL aumenta la proliferación de las células y reduce su envejecimiento (Griffiths y col, 2013). El tamaño y la $\beta$ galactosa son marcadores de senescencia celular (López-Diazguerrero y col, 2005; Chuaire-Noack ycol, 2010) y las células cultivadas con HPL son más pequeñas que cuando son expandidas con FBS y generan menos $\beta$-galactosidasa. Sin embargo, a pesar de sus ventajas, el HPL también presenta desventajas, ya que todavía no está bien comercializado, puede generar reacciones inmunes a nivel alogénico, y además, existe el riesgo de transmisión de virus humanos como el VIH y el Virus linfotrópico humano de células T (HTLV) (Hemeda y col, 2014).

Actualmente, ya disponemos de HPL con certificación GMP para la producción de MSV en la UPC, y tras informar a la AEMPS de los resultados, estamos pendientes de realizar el cambio en el protocolo de fabricación. Sin embargo, cuando se desarrolló esta Tesis Doctoral todavía no disponíamos de este producto conforme GMPs, así que utilizamos medio de cultivo suplementado con suero bovino fetal y este protocolo está autorizado por la AEMPS, ya que el suero bovino fetal empleado en la expansión de las células MSV-H dispone de un certificado de análisis que nos indica que está libre de virus de origen animal por proceder de animales sanos. Tiene además un certificado de idoneidad expedido por el EDQM (European Directorate for the Quality of Medicines) que garantiza la ausencia de riesgo de transmisión de la encefalopatía espongiforme bovina ya que se obtiene de animales de Australia, Canadá y los Estados Unidos de América, países que hasta el momento no presentan ningún caso confirmado de esta enfermedad.

La principal dificultad que hemos tenido en este trabajo para la expansión de MSV$\mathrm{H}$ ha sido la contaminación inicial de la muestras. A pesar de la presencia de antibióticos (P/E) y antimicóticos (anfotericina $A$ ) en el medio de recogida de las mismas se obtuvieron resultados positivos de contaminación microbiológica en el primer análisis de control de calidad realizado en el medio de recogida en 9 de las 11 muestras analizadas. Esto nos indica que partimos de una elevada carga bacteriana inicial que no ha sido eliminada completamente por la acción de los antibióticos durante el trasporte y almacenamiento de la muestra. Para solucionar 
este problema y poder realizar el proceso de expansión, se estableció un periodo de cuarentena en el que se realizaron cambios de medio con antibiótico (P/E) cada 48 horas para diluir la carga bacteriana inicial hasta su total eliminación y obtener crecimiento celular. Esta medida nos permitió descontaminar y realizar la expansión celular en 7 de las 9 muestras que han presentado un resultado positivo inicial; sin embargo, hemos tenido que abortar dos cultivos, que a pesar del periodo de cuarentena, presentaban contaminación.

Una vez obtenidas las células a partir de los explantes de hueso mandibular, hemos realizado la caracterización de las mismas para comprobar que realmente se pueden considerar células mesenquimales humanas, ya que actualmente no existe un protocolo consensuado para la obtención de este tipo celular, lo que genera una gran dificultad para realizar ensayos comparativos. Las MSC presentan diferentes propiedades en función del tejido fuente, del fenotipo y genotipo del donante, y de los métodos utilizados para el aislamiento, el almacenamiento y la expansión de las mismas (Viswanathan y col, 2014), lo que hace necesaria la caracterización previa a su utilización en aplicaciones clínicas.

Actualmente existen diferentes métodos para la caracterización de las células mesenquimales en cultivo, pero la técnica más comúnmente utilizada es la citometria de flujo (Agha-Hosseini y col, 2010, Pilz y col, 2011, Claros y col, 2012; Mark y col, 2013). En este trabajo se analizó el inmunofenotipo de las células mediante esta técnica, que permite el recuento y clasificación de las células según sus características morfológicas (tamaño y complejidad) y por la presencia $(+)$ o ausencia (-) de ciertos biomarcadores.

La bibliografía actual muestra una amplia variedad de marcadores utilizados para caracterizar las MSC. Por ejemplo, Agha-Hosseini y col (2010) utilizan los marcadores CD13, CD31, CD34, CD44, CD45, CD90, CD105 y CD166, para caracterizar las células madre derivadas de pulpa dental; y sin embargo, otros autores utilizan únicamente CD44 y STRO-1 para la caracterización parcial del mismo tipo celular (Magallanes y col, 2010). Por otro lado, el grupo de Akiyama (2012) utiliza los marcadores STRO-1, CD29, CD73, CD90, CD105, CD146, Oct-4 (octamer-4) y SSEA4 (antígeno especifico estado embrionario) para MSC de médula ósea y Lohberger y col (2012) utilizan CD11, CD14, CD34, CD45, 
CD73, CD90, CD105 Y HLA-DR, para caracterizar MSC de hueso maxilar. La Tabla 16 muestra un resumen de los 20 marcadores más utilizados en la caracterización de productos de terapia celular compuestos por MSC y registrados en la base de Nuevos Medicamentos en Investigación (IND) de la FDA (Mendicino y col, 2014).

Tabla 16. Expresión de marcadores fenotípicos de productos celulares basados en MSC y registrados en la IND.

\begin{tabular}{|c|l|c|}
\hline $\begin{array}{c}\text { Clasificación de } \\
\text { marcadores }\end{array}$ & \multicolumn{1}{|c|}{ Nombre } & \% uso \\
\hline 1 & CD45 & 91 \\
\hline $\mathbf{2}$ & CD105 & $\mathbf{7 3}$ \\
\hline $\mathbf{3}$ & CD90 & $\mathbf{6 1}$ \\
\hline $\mathbf{4}$ & CD73 & $\mathbf{5 2}$ \\
\hline 5 & CD34 & 48 \\
\hline 6 & CD14 & 47 \\
\hline 7 & HLA Class II & 44 \\
\hline $\mathbf{8}$ & CD44 & $\mathbf{3 0}$ \\
\hline $\mathbf{9}$ & HLA Class I & $\mathbf{2 6}$ \\
\hline 10 & CD29 & $\mathbf{2 4}$ \\
\hline 11 & CD106 & $\mathbf{2 3}$ \\
\hline 12 & CD19 & 21 \\
\hline 13 & CD80 & 21 \\
\hline 14 & CD86 & 21 \\
\hline 15 & CD166 & $\mathbf{2 0}$ \\
\hline 16 & CD10 & 18 \\
\hline 17 & CD146 & 15 \\
\hline 18 & CD40 & 15 \\
\hline 19 & CD11b & 14 \\
\hline 20 & CD200 & 12 \\
\hline
\end{tabular}

Marcadores positivos en negrita y negativos en cursiva (Mendicino y col, 2014).

Esta gran variabilidad para la caracterización de las MSC se debe a la diversidad de los tejidos utilizados para su obtención y a la variabilidad de donantes (Figura 41). En MSC derivadas de médula ósea existen marcadores (CD49d, CD51, CD71, CD146, CD349, CXCR-4 y MSCA-1) con expresión variable en función de la variabilidad del donante, del protocolo de expansión o del pase en el que se encuentren las células (Wuchter y col, 2015). La variación en el proceso de obtención y expansión puede modificar el patrón inmunofenotípico incluso en células del mismo donante obtenidas del mismo tejido (Mendicino y col, 2014). En este punto, Mark y col (2013) muestran que las mismas células MSC expresan un patrón diferente frente al anticuerpo CD105 cuando se modifican las condiciones de 
cultivo, ya que la expresión es menor si se cultivan sin FBS que si se cultivan con FBS. También hay trabajos que muestran que las células MSC expresan diferente marcaje frente al anticuerpo CD14 (característico monocitos y macrófagos) dependiendo del clon de anticuerpo utilizado (Pilz y col, 2011).

\begin{tabular}{|c|c|c|c|c|c|c|}
\hline & BM - MSC & UCB - MSCs & UCT-MSCs & AT - MSC & DP - MSCs & P-MSCs \\
\hline Isolation & $\begin{array}{l}\text { Gradient } \\
\text { separation }\end{array}$ & $\begin{array}{l}\text { Enzyme/mechanical } \\
\text { dissociation/ } \\
\text { centrifugation }\end{array}$ & $\begin{array}{l}\text { Enzyme/mechanical } \\
\text { dissociation/ }\end{array}$ & $\begin{array}{l}\text { Enzymel } \\
\text { mechanical } \\
\text { dissociation }\end{array}$ & $\begin{array}{l}\text { Fresh tissue } \\
\text { dissection/enzyme }\end{array}$ & $\begin{array}{l}\text { Membrane } \\
\text { separation } \\
\text { (optional), tissue } \\
\text { dissection, enzyme, } \\
\text { centrifugation }\end{array}$ \\
\hline Markers & $\begin{array}{l}\text { CD105, CD73 and } \\
\text { CD90, CD } 45, \text { CD } 34, \\
\text { CD 14 or CD 11b, } \\
\text { CD79a or CD19 and } \\
\text { HLA class II }\end{array}$ & $\begin{array}{l}\text { BM - MSCs markers + } \\
\text { Oct4, Nanog. Sox-2 } \\
\text { (low levels) }\end{array}$ & $\begin{array}{l}\text { BM - MSCs markers + } \\
\text { higher levels of CD146 }\end{array}$ & $\begin{array}{l}\text { BM - MSCs markers } \\
+ \text { higher levels of } \\
\text { CD146; STRO-1 } \\
\text { negative }\end{array}$ & $\begin{array}{l}\text { BM - MSC markers + } \\
\text { STRO-1, CD146 }\end{array}$ & $\begin{array}{l}\text { BM - MSC markers } \\
\text { SSEA-1, SSEA-4, } \\
\text { Oct4, Nanog; } \\
\text { Higher levels of } \\
\text { CD49d, CD 10, and } \\
\text { CD56 than } \\
\text { BM - MSCs }\end{array}$ \\
\hline Limitations & Rare cell type & Low yield & $\begin{array}{l}\text { Developing } \\
\text { field }\end{array}$ & $\begin{array}{l}\text { Heterogeneous } \\
\text { populations }\end{array}$ & $\begin{array}{l}\text { Low yield; fresh } \\
\text { processing }\end{array}$ & $\begin{array}{l}\text { Cumbersome to } \\
\text { procure, properties } \\
\text { need to be better } \\
\text { understood }\end{array}$ \\
\hline
\end{tabular}

Figura 41. Fuentes de MSC, métodos de obtención, diferentes condiciones de cultivo y marcadores utilizados para su caracterización. BM-MSCs (mesenquimales de médula ósea), UCB-MSCs (mesenquimales de sangre de cordón umbilical), UCT-MSCs (mesenquimales de tejidos de cordón umbilical), AT-MSCs (mesenquimales de tejido adiposo), DP-MSCs (mesenquimales de pulpa dental), PMSCs (mesenquimales de placenta) (Viswanathan y col, 2014).

Ante tanta diversidad, la Sociedad Internacional de Terapia Celular (ISCT) (Horwitz y col, 2005; Dominici y col, 2006) ha recomiendado unos criterios mínimos para la caracterización de las MSC utilizadas en terapia celular. El primer criterio es que sean células adherentes de aspecto fibroblástico en condiciones de cultivo estándar, como las células MSV-H obtenidas a partir del hueso mandibular. En cuanto al patrón inmunofenotípico que deben presentar las células, estos criterios incluyen la presencia (+) de los marcadores de superficie CD105, CD73 y CD90; y la ausencia (-) de los marcadores hematopoyéticos como CD34, CD45, CD11a, CD19 y HLA-DR. En la última revisión de la ISCT se sugiere que las células MSC 
de médula ósea en grado GMP deben presentar una expresión positiva $>90 \%$ para los marcadores CD73, CD90 y CD105; y una disminución de la expresión de CD45, siendo aceptable el marcaje en menos del $2 \%$ de la población analizada (Wuchter y col, 2015), pero este punto solo afecta a las MSC obtenidas a partir de médula ósea, y como se ha mencionado, nosotros hemos empleado hueso madibular como tejido fuente para la obtención de las células MSV-H.

En este trabajo se han utilizado los anticuerpos monoclonales indicados en la Tabla 17 marcados con fluoróforos de unión covalente: isocianato de fluoresceina (FITC, verde), ficoeritrina (PE, amarillo) y estreptavidina PE-cianina 5 (PECy5, rojo) para caracterizar las células MSV-H obtenidas a partir de los explantes de hueso mandibular.

Tabla 17. Expresión celular de los marcadores fenotípicos utilizados.

\begin{tabular}{|c|l|c|}
\hline ANTICUERPO & \multicolumn{1}{|c|}{ EXPRESIÓN CELULAR } & $\begin{array}{c}\text { MARCADOR } \\
\text { MSC }\end{array}$ \\
\hline CD14 & Monocitos y macrófagos. & Negativo \\
\hline CD34 & Células madre hematopoyéticas y células endoteliales. & Negativo \\
\hline CD45 & Leucocitos y progenitores hematopoyéticos. & Negativo \\
\hline CD73 & $\begin{array}{l}\text { Células madre mesenquimales, células endoteliales y } \\
\text { epiteliales, células T y y y células dendríticas foliculares }\end{array}$ & Positivo \\
\hline CD90 & Células madre mesenquimales & Positivo \\
\hline CD105 & $\begin{array}{l}\text { Células madre mesenquimales, células endoteliales } \\
\text { vasculares y sincitiotrofoblastos de placenta, células } \\
\text { pre-B en médula fetal, precursores eritroides en médula } \\
\text { ósea fetal y adulta. }\end{array}$ & Positivo \\
\hline CD166 & $\begin{array}{l}\text { Células madre mesenquimales, células T y monocitos } \\
\text { activados, células epiteliales, fibroblastos y neuronas }\end{array}$ & Positivo \\
\hline HLA-DR & Antígeno presente en todas las células y en linfocitos. & Negativo \\
\hline
\end{tabular}

Los resultados obtenidos del análisis por citometría de flujo nos mostraron que las células aisladas de explantes de hueso y mantenidas en cultivo, presentan una expresión positiva para los marcadores CD90, CD73 y CD166, una positividad débil para CD105 y no expresan los marcadores CD34, CD45, CD14 y HLA-DR. 
Hasta el momento los resultados analizados nos indican que las células obtenidas a partir de los explantes de hueso cumplen dos de los tres criterios mínimos recomendados por la ISCT para ser consideradas MSC (Horwitz y col, 2005; Dominici y col, 2006, Wuchter y col, 2015): son adherentes en cultivo y expresan los marcadores de superficie CD105, CD73 y CD90 característicos de MSC; y no presentan los marcadores hematopoyéticos CD34, CD45, el marcador de característico de monocitos CD14 y el complejo mayor de histocompatibilidad HLADR.

El último criterio recomendado por la ISCT es la diferenciación en medios condicionados. La diferenciación es el proceso por el cual las células de un linaje celular sufren modificaciones en su expresión génica para adquirir la morfología y las funciones de un tipo celular específico y diferente. En este punto, las células en cultivo "in Vitro" detienen el proceso de duplicación para empezar a realizar funciones específicas del tejido al que se van a diferenciar, lo que implica la síntesis de proteínas específicas y la formación de matriz extracelular.

Para comprobar si las células MSV-H mantienen la capacidad de diferenciación osteogénica, utilizamos un medio suplementado con dexametasona, L-ascorbato y $\beta$-glicerol fosfato como morfógenos. Este medio es ampliamente utilizado para una diferenciación osteogénica óptima, ya que permite la obtención de células de morfología osteoblástica con expresión de fosfatasa alcalina, modulación de la producción de mRNA de osteocalcina y formación de matriz extracelular mineralizada con hidroxiapatita (Jaiswai y col, 1998).

Los morfógenos o factores de diferenciación generan cambios en la expresión génica de las células promoviendo la osteogénesis (Pineda y col, 2009). La dexametasona estimula la proliferación de las MSC y permite su diferenciación hacia el linaje osteogénico. El $\beta$-glicerol fosfato es un fosfato inorgánico que promueve la osteogénesis mediante el control de la mineralización y la actividad de los osteoblastos (Chung y col, 1992), ya que los fosfatos libres inducen la expresión de mRNA y proteínas osteogénicas como la osteopontina. Y el L-ascorbato promueve la producción de osteocalcina que actúa como cofactor en la hidroxilación de los residuos de prolina y lisina en el colágeno, por lo que es esencial para su deposición en la matriz extracelular. También incrementa la 
síntesis deproteínas no colágenas de la matriz ósea, por lo que participa en todas la fases de la osteogénesis hasta que se forman los osteocitos. Los estudios de Akiyama y col (2009) muestran que la presencia de ácido ascórbico es esencial para la formación de hueso, ya que utilizando un medio sin este factor no se obtiene formación de tejido óseo.

Se ha descrito que las MSC humanas mantienen el potencial de diferenciarse hacia linaje osteogénico durante aproximadamente 40 duplicaciones en cultivo e incluso después de la criopreservación (Jaiswal y col, 1997; Bruder y col, 1997) y en este trabajo se han utilizado células MSV-H en pase 3 y 4 , por lo que se supone que mantienen el potencial de diferenciación osteogénica. No obstante, para verificarlo, las células MSV-H se han mantenido en cultivo con el medio condicionado durante 21 días y pasado este tiempo se comprobó la existencia de fosfatasa alcalina, que es un marcador de expresión temprana en la diferenciación osteogenica, que aparece en células osteoprogenitoras, osteoblastos y osteocitos jóvenes a diferencia de otros marcadores de hueso como la osteocalcina que se expresa en un estadio más tardío dentro de la diferenciación osteogénica. (Sell y col, 1997). La presencia de células fosfatasa alcalina positivas en un cultivo, indica que están destinadas a diferenciarse en osteoblastos (Deans y col, 1999), ya que es una enzima que libera fosfato inorgánico a partir de esteres fosfóricos y juega un papel importante en la mineralización, proliferación, migración y diferenciación de las células hacia linaje osteoblastico. La tinción con FA es un análisis sencillo y económico, lo que permite incluirlo en los test rutinarios de caracterización de producto final.

Los resultados obtenidos en las tinciones de fosfatasa alcalina realizados a las células MSV-H fueron positivos, lo que nos permiten confirmar que las células expandidas a partir de los fragmentos de hueso esponjoso mandibular se diferencian hacia linaje osteoblástico cuando se mantienen en un medio de cultivo condicionado.

En este punto y con los resultados obtenidos, podemos concluir que las células MSV-H obtenidas a partir del hueso esponjoso mandibular pueden ser consideradas MSC ya que cumplen los principales criterios recomendados por la ISCT. 


\subsection{OBTENCIÓN DE LA MATRIZ TRIDIMENSIONAL}

La ingeniería tisular permite la obtención de tejidos completos a partir de la combinación de cultivos celulares, factores de crecimiento y matrices tridimensionales. Actualmente esta disciplina está en auge para la reconstrucción de nuevos tejidos de reemplazo y para la regeneración de estructuras destruidas o perdidas (Tortolini y col, 2012). En este punto, destaca la aplicación de las MSC con diferentes biomateriales para la regeneración fundamentalmente de tejido óseo y de cartílago. (Petite y col, 2000; Gallego y col, 2010; Grayson y col, 2015).

El primer objetivo de la ingeniería tisular de hueso es crear un ambiente que permita la diferenciación osteogénica de las células madre dentro de matrices tridimensionales para generar construcciones óseas "in Vitro" (Fröhlich y col, 2008).

La matriz es uno de los puntos críticos, ya que aporta el soporte necesario para que las células crezcan en un ambiente tridimensional adecuado y reemplacen el tejido dañado. (Salgado y col, 2004). El injerto ideal generado mediante ingeniería tisular debe ser osteogénico, osteoconductivo y osteoinductivo (Kaveh y col, 2010). Por ello el desarrollo de la matriz es un proceso complejo que incluye la elección del material adecuado, la arquitectura, la estructura mecánica, las propiedades de superficie, las propiedades y productos de degradación, junto con la composición de los componentes biológicos añadidos y, por supuesto, los cambios de todos estos factores con el tiempo (Hutmacher y col, 2007).

Para que la reparación del tejido se realice con éxito, las características fundamentales de un biomaterial son: biocompatibilidad, propiedades mecánicas (elasticidad, resistencia,), morfología porosa e interconectada y biodegradabilidad.

Actualmente existe una gran diversidad de biomateriales.Para la regeneración ósea se utilizan básicamente biocerámicas, polímeros naturales y polímeros sintéticos (Rezwan y col, 2006); los metales se utilizan principalmente en el campo de la ortopedia.

Las biocerámicas son materiales bioactivos con una estructura similar a la matriz ósea (Plazas-Bonilla y col, 2011). Los más utilizados son la hidroxiapatita (HA) que puede ser de origen natural o sintético (Martínez-Valencia y col, 2008) y el fosfato 
tricálcico (TCP). Ambos permiten la fabricación de matrices osteoconductivas. La HA es el material cerámico más utilizado para regeneración ósea, ya que es el principal componente de los huesos en los mamíferos (60-70\% del peso seco), y presenta una estructura muy similar a la matriz ósea. Esta estructura junto con su osteoconductividad, permiten que el tejido conectivo que rodea el defecto penetre y realice el proceso de osificación del material, reparando el tejido dañado (VelascoPeña y col, 2010).

Los polímeros sintéticos más utilizados son el ácido poliláctico (PLA) y el ácido poliglicólico (PGA), que son polímeros biodegradables, pero generan matrices delicadas que no son osteoconductivas. La introducción de poros en estas matrices hace que disminuya la resistencia de las mismas a medida que aumenta la porosidad. Sin embargo, cuando se combinan con biocerámicas se obtienen matrices osteoconductivas y más resistentes (Wang, 2006). En este grupo, se incluyen los polímeros tipo elastina (ELP), que se obtienen de forma recombinante y mimetizan la estructura de la elastina natural, que como sabemos, es uno de los componentes más importantes de la matriz extracelular. Estos polímeros se consideran inteligentes porque son capaces de responder a estímulos ambientales. Por ejemplo, son capaces de modificar su estado en función de la temperatura ambiental o por la acción de cambios químicos (Martín y col, 2009; González de la Torre y col, 2014; Testera y col, 2015).

Los polímeros naturales son materiales biodegradables como el colágeno, el chitosan, el almidón o los glicosaminoglicanos. En este grupo se puede incluir la matriz ósea desmineralizada que se utiliza como material de relleno en defectos óseos y es osteoinductiva. Contiene factores de crecimiento como las BMPs, lo que favorece la formación de hueso incluso en localizaciones ectópicas (Blackwood y col, 2012). En este punto, destaca la BMP-2 que actúa como agente quimiotáctico y promueve la proliferación y diferenciación osteoblástica de las MSC. Además, su aplicación aumenta la osteocalcina lo que induce la formación de tejido óseo (Pulido y col, 2013). En el grupo de los polímero naturales, se encuentran los hemoderivados como el plasma rico en plaquetas (PRP), que aumenta la velocidad de regeneración ósea por la concentración de factores de crecimiento existentes en las plaquetas (Rodríguez Flores y col, 2012). El PRP es ampliamente utilizado como adhesivo biológico, ya que permite la estabilización o cohesión de los injertos 
óseos particulados y facilita la cicatrización de las heridas (González Lagunas, 2006). En este punto, también destaca la utilización de la fibrina autóloga, ya empleada en 1994 por un grupo de cirujanos como adhesivo al hueso esponjoso durante la reconstrucción mandibular (Tayapongsak y col, 1994). La fibrina actúa como sustrato para la migración de MSC, acelera la revascularización y la migración de fibroblastos, estimula el crecimiento de fibroblastos y osteoblastos y reduce la multiplicación de microorganismos, por lo que presenta características más osteogénicas que el PRP (Zhu y col, 2006). Sin embargo, las matrices generadas con PRP y fibrina son de rápida degradación y escasa resistencia mecánica, ya que se utilizan básicamente en forma de geles. Por este motivo no son esenciales en el campo de la ingeniería tisular ósea. Sin embargo, podemos destacar su utilización de forma combinada con biocerámicas como la HA o el TCP, que aportan la resistencia mecánica del injerto y las características osteiconductivas, mientras que el PRP o la fibrina aportan las propiedades osteoinductivas (Jimi y col, 2012).

Ante la diversidad existente de materiales para la elaboración de matrices tridimensionales mediante ingeniería tisular, se ha elegido un material natural de naturaleza proteica como son las proteínas globulares del suero, principalmente la albúmina entrecruzada por uniones covalentes con un grupo aldehído (glutaraldehído). La matriz tridimensional en este trabajo se realiza como se ha descrito en la patente del Dr. Meana WO2008/11985, de la que es coautora la doctoranda.

La albúmina es la proteína principal de la sangre, se sintetiza en el hígado y su función principal es el mantenimiento de la presión osmótica y el transporte de sustancias (hormonas, fármacos y drogas). Representa el $60 \%$ de las proteínas que contiene el suero o el plasma, lo que permite la fabricación de la matriz de forma directa a partir de estos. La posibilidad de utilizar plasma o suero humano para la fabricación de la matriz permite su realización de forma autóloga, ya que para su fabricación sólo se necesita una muestra de sangre del paciente. En este punto, el material elegido para la fabricación es el suero autólogo, que es equivalente al plasma pero sin las proteínas involucradas en la coagulación (fundamentalmente fibrinógeno). El glutaraldehido es un compuesto químico ampliamente utilizado como desinfectante de equipos médicos y odontológicos. Presenta dos grupos 
aldehído reactivos que tienden a bloquear las proteínas de adhesión celular, lo que le confiere alta capacidad para mantener la estructura celular, de aquí que sea utilizado fundamentalmente en el laboratorio como fijador. Además, su reacción con los compuestos biológicos, principalmente las proteínas, genera una red de entrecruzamiento básicamente irreversible, por lo es un agente entrecruzante muy fuerte. Sin embargo, por su toxicidad, no es un producto adecuado para la fabricación de matrices aptas para el cultivo celular. En la fabricación de nuestra matriz se ha elegido, no obstante, el glutaraldehído, porque el proceso de liofilización anula el efecto tóxico del mismo, ya que se elimina la fracción acuosa de la matriz y el glutaraldehído no fijado a la proteína globular. En la fase de liofilización se obtiene una matriz porosa y friable que no ofrece resistencia mecánica; sin embargo, estas características se modifican durante el proceso de hidratación, lo que permite obtener como resultado final una matriz porosa, elástica y no tóxica (Gallego y col, 2010; Ferrero-Gutierrez y col, 2013), que es muy adecuada para el cultivo de células para la regeneración ósea.

El glutaraldehído también es utilizado por otros grupos en los procesos de fabricación de matrices. El grupo de la Dra. Vallet-Regí, lo utiliza para recubrir matrices espumosas de HA. Este recubrimiento no afecta a la estructura porosa ni a la adhesión celular, pero sin embargo, permite aumentar el tiempo de degradación de la matriz sin la generación de productos citotóxicos; lo que aumenta su potencial para la regeneración del tejido óseo (Cicuéndez y col, 2011).

La elección del suero como material de partida nos ha permitido obtener matrices biocompatibles, ya que se pueden realizar de forma autóloga, lo que elimina el riesgo de repuesta inmune. El entrecruzamiento de las proteínas del suero con el glutaraldehído forma una estructura esponjosa estable y de fácil manejo, que mejora las propiedades mecánicas de las matrices realizadas con PRP y fibrina.

La elección del biomaterial para la fabricación de la matriz es muy importante porque determina las propiedades mecánicas y su comportamiento de degradación. Además, el material es el que condiciona las propiedades de superficie de la matriz, de gran importancia para las interacciones biológicas (proteínas y péptidos de 
adhesión, adhesión celular, migración, proliferación y diferenciación) (Hutmacher y col, 2007). En este estudio, la naturaleza proteica de la matriz aporta las señales necesarias para facilitar el anclaje celular a la superficie de la misma, su distribución y diferenciación; ya que el suero además de la albúmina, posee otro tipo de proteínas globulares (alfa, beta y gamma-globulinas) y de adhesión (fibronectina y vitronectina) que actúan como moléculas de adhesión celular y por lo tanto aumentan las características osteoconductivas de la matriz generada (Jimi y col, 2012).

La porosidad es un punto crítico a la hora de generar matrices tridimensionales porque debe permitir la distribución de las células en su interior. El tamaño de poro óptimo para que esto ocurra es un tema de debate en muchos estudios. El grupo de Burg (2000) estableció un tamaño de poro ideal para la ingeniería tisular de hueso entre 200 y $400 \mu \mathrm{m}$, ya que una osteona mide alrededor de $223 \mu \mathrm{m}$. Sin embargo, otros autores como Tortolini y col (2010) establecen que el tamaño de poro óptimo oscila entre 100 y $500 \mu \mathrm{m}$, ya que una célula humana tiene un tamaño aproximado entre 10 y $100 \mu \mathrm{m}$ y la porosidad de la matriz debe permitir la penetración de las células, su distribución e intercomunicación y la síntesis de matriz extracelular. Un tamaño de poro pequeño $(<38 \mu \mathrm{m})$ haría que las células formaran un revestimiento multilaminar en la superficie de la matriz (Zeltinger y col, 2001), sin penetrar en la misma. Por lo tanto, la porosidad es crítica, porque además de la distribución celular, es importante para permitir la neovascularización a partir de los tejidos adyacentes una vez que el bioimplante sea injertado. En este punto, se recomienda un tamaño de poro > $300 \mu \mathrm{m}$ para permitir que la vascularización del injerto sea suficiente (Hutmacher y col, 2007).

Las diferentes técnicas de fabricación son claves a la hora de fabricar matrices porosas. En la fabricación de matrices con fases de congelación, la temperatura es esencial, ya que esta influye en el tamaño de los cristales de hielo formados que son los que van a determinar el tamaño de poro de la estructura final. A menor temperatura de congelación la cristalización es más rápida y homogénea, por lo que se generan matrices con un tamaño de poro menor y una distribución más homogénea de los mismos (O'Brien y col, 2004; O’Brien y col, 2005). En este punto, destacan las técnicas recientes de prototipado rápido permiten generar un gradiente de tamaño de poro lo que mejora la eficacia de la siembra celular y permite una distribución más homogénea (Sobral y col, 2011). 
La matriz desarrollada en este trabajo lleva una fase de congelación a $-80^{\circ} \mathrm{C}$, lo que nos permite obtener una distribución homogénea de los poros con un tamaño entre 150 y $300 \mu \mathrm{m}$ (Figura 42). Este tamaño de poro permite la penetración celular y su proliferación como hemos comprobado con los estudios realizados "in Vitro" y aunque los poros se podrían considerar mas bien pequeños para permitir la neovascularización, los estudios "in Vivo" demuestran la existencia de elementos vasculares en los injertos realizados, por lo que el tamaño de poro de la matriz fabricada en este trabajo permite la vascularización del nuevo tejido, lo que favorece la formación de tejido óseo (Kanczler y col, 2008).

La última característica a tener en cuenta en la elección del material para preparar la matriz es la biodegradabilidad. La matriz debe degradarse progresivamente mientras es sustituida por el nuevo tejido formado, además los compuestos generados durante la degradación deber ser fácilmente eliminados por el cuerpo y no generar toxicidad (Freyman y col, 2001). En este caso, al ser una matriz de naturaleza proteica se degrada sin generar compuestos tóxicos.

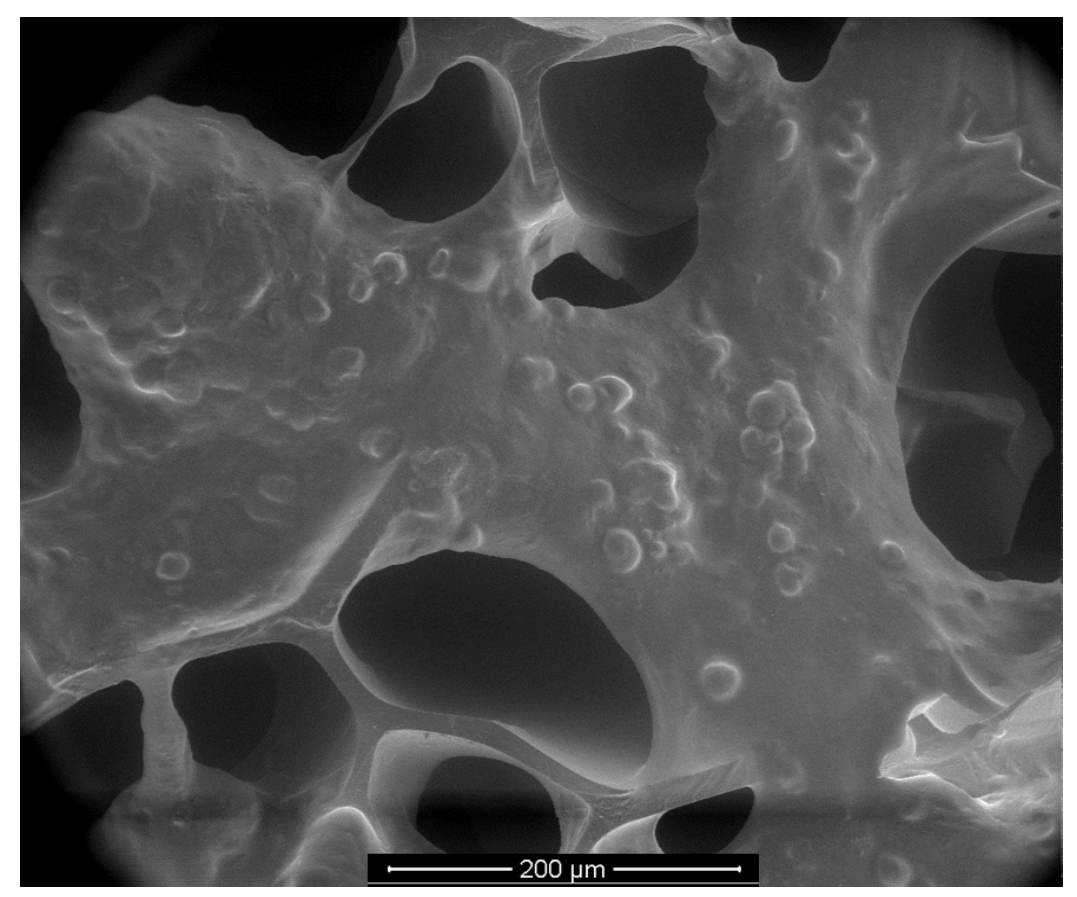

Figura 42: Imagen de microscopia electrónica de barrido de la matriz porosa donde se puede ver el tamaño de poro. 
La realización de la matriz bajo normativa GMP ha sido el punto más crítico, ya que el proceso de liofilización no se puede realizar dentro de un ambiente controlado como el de la Sala Blanca. Ante este problema, hemos establecido una sala de liofilización en una zona anexa para realizar las manipulaciones de la matriz. Esta sala se compone de una cabina de ambiente A en una sala limpia de ambiente no controlado. En cada una de las fases de elaboración de la matriz se realizan los mismos controles de calidad que en la sala de producción: ambiente, personal y producto. La única diferencia es que no se realiza la monitorización de partículas, ya que en la sala de producción se trabaja en ambiente grado $A$ rodeado de $B$ y en la sala de liofilización tenemos grado $A$ rodeado de un ambiente no clasificado. El control del personal se realiza igual en ambas salas, mediante la toma de una muestra de impresión de guantes al final de cada fase.

Además de los controles de ambiente y personal realizados en todas las fases del proceso, se establecieron cuatro controles de calidad al producto fabricado (matriz). El primer control se realiza en el material de partida previamente analizado mediante una serología para la determinación de $\mathrm{VIH}$, Hepatitis $\mathrm{B}, \mathrm{C}$ y sífilis. En este punto nosotros solo realizamos análisis microbiológicos para determinar la presencia/ausencia de microorganismos aerobios, anaerobios y micoplasma. Posteriormente, se realizan dos controles a la matriz en diferentes puntos de la fabricación: matriz liofilizada y matriz hidratada; en ambos puntos se realiza un ensayo de esterilidad para detectar la presencia/ausencia de microorganismos aerobios y anaerobios. En este punto, la matriz hidratada se mantiene en cuarentena hasta que se obtienen los resultados de control de calidad. Si los resultados en los controles realizados son negativos, consideramos que la matriz hidratada es un producto estéril y en este momento se introduce en la sala de producción de la UPC. El análisis final se realiza en el último lavado de la matriz antes de sembrar las células MSV-H para la fabricación del bioimplante. Este punto de control se realiza dentro de la sala de producción y se analiza de nuevo la presencia/ausencia de microorganismos aerobios, anaerobios y micoplasma.

El protocolo de fabricación de la matriz tridimensional en la sala de liofilización y los controles de calidad establecidos han sido validados y autorizados por la AEMPS antes de iniciar el ensayo clínico, lo que nos permite fabricar una matriz con calidad según normas GMP apta para su aplicación clínica. 


\subsection{CULTIVO DEL BIOIMPLANTE "BIOMAX"}

La ingeniería tisular tiene dos desafíos a la hora de generar un bioimplante: un sembrado homogéneo de las células y una matriz porosa para la difusión de nutrientes y oxígeno en su interior, lo que permite la proliferación celular y la formación de nuevo tejido (Melches y col, 2010). En este punto es muy importante la arquitectura de la matriz tridimensional, que debe mimetizar la estructura de la matriz extracelular del tejido que se quiere reparar para así facilitar la regeneración del mismo, y por lo que hemos visto hasta ahora, la matriz tridimensional fabricada en este trabajo presenta características prometedoras para la regeneración del tejido óseo.

La distribución de las células en el interior del material poroso es crítica para determinar el éxito o fracaso de un bioimplante en ingeniería tisular. La homogeneidad de las células en este punto se consigue mediante un sembrado dinámico que permite la penetración de las mismas desde la periferia donde se realiza el sembrado hasta el interior de la matriz (Burg y col, 2000). Las técnicas de cultivo estáticas solo permiten la penetración de las células en las zonas superficiales de la matriz, dejando el interior de la misma acelular.

Actualmente existen diferentes técnicas de sembrado dinámico. Goldstein y col (2001) muestran una mejor distribución de las células en matrices esponjosas con vasos rotacionales o mediante un sistema de flujo. Godbey y col (2004) sin embargo, siembran las células mediante una centrifugación a 40 rpm durante 24 horas, lo que permite la penetración de las células en las matrices cilíndricas, pero esta técnica solo ha resultado efectiva cuando utilizaban suspensiones de baja concentración celular. Li y col (2007) aplican ondas acústicas en la superficie del cultivo que conducen una suspensión celular hacia el interior de una matriz porosa, lo que permite la distribución uniforme de las células por la matriz. $Y$ el grupo de Nieponice (2008) desarrolló un dispositivo de siembra rotacional en vacío que permite una rápida penetración de las células en matrices tubulares.

Los problemas de difusión de las células dentro de las matrices porosas, hace que nos planteemos un sistema de sembrado dinámico. Por eso, en este trabajo, la siembra de las MSV-H en la matriz tridimensional para la fabricación del bioimplante 
"Biomax" se realizó mediante agitación continua durante 24 horas. Pasado este tiempo, se voltea la matriz y se deja 3 horas más en agitación antes de iniciar el cultivo de diferenciación. Este sistema de sembrado ha permitido una distribución homogénea de las células en la matriz. El grosor del bioimplante generado ( $3 \mathrm{~mm})$ no nos permite profundizar cuando realizamos el seguimiento del cultivo con el microscopio de contraste de fases, por lo que es difícil verificar la distribución celular dentro del mismo. Sin embargo, como realizamos el volteo de la matriz sembrada antes de iniciar el cultivo de diferenciación, lo que comprobamos es que las células se han distribuido en toda la profundidad del bioimplante.

Además de la dificultad para verificar la difusión de las células en la matriz, los cultivos 3D en terapia avanzada, presentan la dificultad de conocer la dosis exacta de células que contiene la matriz. En este punto, no podemos determinar el número exacto de MSV-H que forman parte del medicamento bioimplante "Biomax". La concentración celular estipulada en el bioimplante es de 5 a $10 \times 10^{6}$ células por disco. Ante la dificultad de conocer la dosis celular exacta hemos sembrado aproximadamente $10 \times 10^{6}$ células en 21 de los 27 bioimplantes generados, ya que en dos pacientes tratados con 3 bioimplantes cada uno, no se ha obtenido el rendimiento celular esperado. De esta forma, considerando que las pérdidas celulares durante el proceso de sembrado son aproximadas en todos los bioimplantes por la repetitividad del mismo, no podemos determinar el número exacto de células pero podemos estimar que todos presentan una concentración celular similar.

Los bioimplantes generados para la reconstrucción de tejido óseo, pueden presentar MSC diferenciadas o indeferenciadas, pero la mejor opción es utilizar células diferenciadas aunque esto supone un mayor tiempo de cultivo (Mohamadreza y col, 2011). Este punto lo hemos podido confirmar en los ensayos animales realizados "in Vivo" en defectos críticos mandibulares, donde de los 4 grupos experimentales los mejores resultados se obtuvieron en el grupo que se implanto matriz con células diferenciadas durante 21 días en medio osteogénico.

Es sabido que las condiciones ambientales del cultivo permiten que las MSC se diferencien hacia un fenotipo determinado debido a la plasticidad que poseen, así, la utilización de estimulaciones mecánicas hace que las células se diferencien hacia células de músculo liso (Nieponice y col, 2006). Por otro lado; las condiciones de 
hipoxia permiten la diferenciación hacia linaje condrogénico (Cao y col, 2015). Fianlemte, la utilización de medios condicionados con diferentes morfógenos también permite la diferenciación de las MSC hacia un tipo celular determinado. Por ejemplo, la suplementación del medio con dexametasona, indometacina e insulina, condicionan las MSC hacia una diferenciación adipogénica (Linero y col, 2014).

En este trabajo se mantiene el bioimplante durante 21-30 días con un medio condicionado de diferenciación osteogénica, suplementado con dexametasona, LAscorbato y $\beta$-glicerol fosfato. La dexametasona permite la diferenciación de las MSC en cultivo; el ascorbato aumenta los depósitos de colágeno en la matriz extracelular y el $\beta$-glicerol fosfato juega un papel importante en la mineralización de la misma (Mohamadreza y col, 2011), por lo que los tres morfógenos son esenciales para la diferenciación hacia tejido óseo como hemos visto en el punto 1.1. Por lo tanto, el cultivo del bioimplante en este medio permite la diferenciación de las MSV-H incluidas en la matriz hacia un linaje osteogénico. Ante la dificultad de verificar la diferenciación de las células en el bioimplante para aplicación clínica, esta se comprobó mediante el control de calidad de producto terminado que se realiza en 50.000 células $\mathrm{MSV}-\mathrm{H}$ sembradas en un pocillo en el mismo momento que se incluyen en la matriz tridimensional y con el mismo medio condicionado. Ambos (bioimplante y células) se mantienen en cultivo de forma paralela, el mismo periodo de tiempo y una vez finalizado el cultivo de los bioimplantes, se analiza la presencia de fosfatasa alcalina en el cultivo paralelo.

El resultado positivo obtenido en la expresión de fosfatasa alcalina en estos cultivos paralelos nos permite afirmar que las células MSV-H incluidas en el bioimplante han iniciado la diferenciación hacia linaje osteogénico de forma similar, ya que una vez que las células MSC inician su diferenciación hacia osteoblastos, comienzan a expresar componentes del hueso entre los que destacan: fosfatasa alcalina, colágeno, osteocalcina y osteonectina; y como hemos visto, la fosfatasa alcalina es un marcador expresión temprana en la diferenciación osteogénica.

El bioimplante "BIOMAX" ha sido desarrollado en su totalidad bajo normativa GMP en la UPC del IBGM, por lo que puede ser utilizado como medicamento en investigación clínica. Además, el origen autólogo de todos sus componentes (matriz y células) hace que se eviten todo tipo de respuesta inmunológica y la presencia de 
células mesenquimales prediferenciadas hacia linaje osteogénico favorece la regeneración del tejido óseo, por lo que puede ser un buen candidato para la ingeniería tisular ósea.

\section{ESTUDIOS PRECLÍNICOS}

Los estudios preclínicos constituyen una etapa crucial en el desarrollo de nuevos medicamentos, y actualmente constituyen un cuello de botella en el desarrollo farmacéutico, concretamente para el paso del producto de laboratorio a la fase de medicamento de aplicación clínica.

El objetivo de la fase preclínica es estudiar la eficacia y seguridad del medicamento en sistemas celulares "in Vitro" y/o en animales "in Vivo". Además, el desarrollo de esta es un requisito indispensable para obtener la autorización de las entidades reguladoras para realizar un ensayo clínico.

La disponibilidad de cultivos celulares permite el desarrollo de modelos "in Vitro", pero son una simplificación de lo que ocurre realmente en el ser vivo y ofrecen una información limitada. Esto hace necesario la realización de estudios "in Vivo" en un modelo animal que nos permita extrapolar los resultados al hombre, y así, poder dar el paso de la investigación a la clínica.

\subsection{ESTUDIOS “IN VITRO”}

Los estudios "in Vitro" nos han permitido perfeccionar el cultivo de explantes de hueso mandibular para la obtención de MSV-H y comprobar la eficacia de adhesión de las mismas a la matriz tridimensional. El primer paso ha sido la obtención de las células mesenquimales a partir de los explantes de hueso mandibular, con los problemas de contaminación inicial que presentaba la muestra. El mantenimiento de las condiciones de cultivo "in Vitro" es esencial para el proceso de expansión, ya que cuando las células se expanden en condiciones inapropiadas pierden la capacidad de proliferación y el potencial de diferenciación, lo que las hace inadecuadas para su utilización en terapias celulares. En este caso, el cultivo se ha realizado en condiciones controladas a $37^{\circ} \mathrm{C}$ y el $5 \%$ de $\mathrm{CO}_{2}$, y una vez superados los problemas de contaminación inicial mediante la combinación de antibióticos $(\mathrm{P} / \mathrm{E})$, el periodo de cuarentena con la renovación del medio de cultivo cada 48 
horas y el trabajo en condiciones de esterilidad, se ha realizado la expansión de las células sin inconvenientes lo que permitió su proliferación sin perder la capacidad de diferenciación.

El segundo paso, ha sido la producción de la matriz tridimensional. La materia prima elegida para realizarla fué suero humano, que además de la albúmina entrecruzada con glutaraldehido para la fabricación de la matriz porosa, posee otras proteínas que facilitan la adhesión celular (Jimi y col, 2012). Las imágenes de microscopia de electrónica de barrido nos permitieron comprobar la porosidad de la matriz, la adhesión de las células a la misma y que la siembra en agitación continúa permitía la distribución de las células en el interior de la matriz de una forma homogénea.

Finalmente, hemos comprobado que las células incluidas en la matriz son capaces de diferenciarse hacia linaje osteoblástico cuando se mantienen en un medio condicionado, es decir, minimizan los procesos de duplicación realizados en la fase expansión para empezar a realizar funciones específicas del tejido al que se van a diferenciar, en este caso, tejido óseo. Este estudio se realizó mediante histología con tinciones Von Kossa. Esta tinción sustituye los depósitos intracelulares de calcio por plata, que al ser expuesta a la luz se oxida y se vuelve de color negro, lo que permite observar los frentes de osificación. Los resultados obtenidos en la tinción Von Kossa son células adheridas a la matriz con una granulación intracelular teñida de negro, lo que nos indica, que las células presentan depósitos de calcio, y por lo tanto han iniciado la diferenciación hacia linaje osteoblástico.

Una vez desarrollado el bioimplante "in Vitro" (matriz tridimensional y células MSVH) y comprobado que las células crecen y se diferencian en su interior, pasamos a realizar estudios en animales para comprobar su comportamiento "in Vivo".

\subsection{ESTUDIOS "IN VIVO"}

El desarrollo de esta fase experimental es fundamental para la obtención de los resultados esperados. En nuestro caso, encaminamos la investigación a la reparación de pequeños defectos óseos. El estudio de la reparación de un defecto óseo es importante en cirugía ortopédica y odontológica. Los defectos óseos pueden ser de tamaño crítico (no se reparan espontáneamente) o de tamaño no crítico (se reparan espontáneamente), sin embargo, es necesario realizar estudios para inducir la reparación completa en ambos tipos de defectos (Hernández-Flores y col, 2001). Así que enfocamos la regeneración al terreno de la cirugía 
oral y maxilofacial donde nos encontramos con defectos óseos provocados por diferentes causas (traumatismos, tumores, etc.) que constituyen un reto terapéutico importante, ya que precisan una reconstrucción que garantice un adecuado resultado estético y funcional (Pérez Cardigal y col, 2008). Además, el hecho de que el hueso mandibular este sometido a un estrés mecánico continuo, lo hace doblemente interesante en el campo de la regeneración ósea.

La utilización de animales de experimentación ha sido de gran controversia por los aspectos éticos y morales que lleva su empleo en investigación. Sin embargo, el animal de laboratorio es una de las piezas fundamentales en las ciencias biomédicas utilizado como modelo para investigar y comprender las causas, diagnóstico y tratamiento de enfermedades que afectan al humano. Sus aportaciones en la docencia biológica y en el desarrollo, producción y control de medicamentos y alimentos, los hacen insustituibles en el campo de la investigación médica (Hernández, 2006).

El ratón y la rata son los animales más utilizados en investigación al tratarse de un mamífero; una gran parte de sus procesos bioquímicos son similares al hombre, además, tiene corto tiempo generacional (19-21 días), presenta una elevada tasa reproductiva y es de fácil mantenimiento. Sin embargo, actualmente se están desarrollado y perfeccionando una gran variedad de modelos animales transgénicos que permiten construir modelos genéticos de enfermedades humanas de gran interés en el campo de la biomedicina. La elección de la rata para los experimentos "in Vivo" como receptor tiene la ventaja de que presenta un defecto crítico mandibular claramente definido (Kaban y col, 1979 y 1981) y además, el equipo clínico quirúrgico tiene amplia experiencia con estos animales. Por otro lado, la elección del material humano como donante se ha realizado para reducir a la diferencia temporal que existe entre la obtención del bioimplante (células y matriz) "in Vitro" y su posible aplicación "in Vivo", que sería aproximadamente de 8 semanas si realizamos el bioimplante autólogo. De esta forma, también se evita la doble cirugía en los animales, una para la obtención de las muestras de hueso y sangre y la otra para la aplicación del bioimplante. En nuestro caso, tenemos una disponibilidad continua de muestras de hueso de origen humano en el servicio de cirugía máxilofacial para la obtención de MSV-H humanas. Este hecho, junto con el suministro continuo de suero a partir de un banco de sangre (CCST de Asturias) 
para la elaboración de la matriz, permiten que la bioingeniería pueda ser realizada previamente a ser implantada en el animal. Además, está la comodidad de continuar con el protocolo de fabricación del bioimplante previamente establecido en los ensayos "in Vitro". Todas estas razones hacen que nos decantemos por utilizar un xenoinjerto formado por células y matriz de origen humano.

El empleo de células y matriz de origen humano sin embargo, nos obliga a emplear un modelo de animal de investigación inmunodeprimido (ratas atímicas rnu/rnu y ratones nu/nu), para evitar problemas de inmunocompatibilidad que puedan interferir en el estudio, por lo que empleamos ratones y ratas atímicas como receptores. En este punto, realizamos injertos heterotópicos en una zona anatómicamente diferente al tejido que queremos reparar, en este caso el tejido óseo. Estos injertos nos ofrecen información de la capacidad del bioimplante "Biomax" para la formación de hueso ectópico y para evaluar si se produce vascularización en el bioimplante una vez injertado. Estos estudios se realizan con injertos en el dorso de ratón y en la zona inguinal de las ratas. Además, realizamos injertos ortotópicos en defectos críticos mandibulares en ratas para comprobar la capacidad del bioimplante para la regeneración ósea. En ambos casos se han utilizado animales inmunodeprimidos.

Los estudios "in Vivo" nos han permitido comprobar que la matriz tridimensional diseñada mediante ingeniería tisular posee las características esenciales de biocompatibilidad, porosidad, propiedades de superficie, osteoinductividad, propiedades mecánicas y biodegradabilidad (Salgado y col, 2004), para ser una matriz ideal; y si estas propiedades se mantienen cuando se vehiculiza a las células MSV-H formando el bioimplante.

En cuanto a la aplicación clínica, la matriz desarrollada en este trabajo a partir de suero humano, tiene una naturaleza proteica que le facilita la integración en el organismo receptor; ya que existe un contacto directo entre el hueso vivo y el material implantado (Albrektsson y col, 1981; Albrektsson y col, 2001). Además, la posibilidad de poder fabricarse de forma autóloga a partir de una muestra de sangre del paciente evita todo tipo de respuesta inmunológica. Por otro lado, las células MSV-H que forman el bioimplante cuando se siembran en la matriz, también son de 
origen autólogo, por lo que el bioimplante tampoco es inmunogénico, lo que evita el rechazo del injerto. En este aspecto, el bioimplante que hemos generado es totalmente biocompatible.

La porosidad de la matriz es de gran importancia para la penetración celular y la distribución de las mismas en el bioimplante. Además, el tamaño del poro debe permitir la neovascularización a partir del tejido adyacente al injerto.

Los injertos en forma de partículas o en esponjas facilitan la penetración de los vasos sanguíneos, transformándose en un proceso de reparación más rápida que los injertos en forma de bloque, ya que la estructura cortical del bloque es una barrera física para la penetración de las células y para la formación de vasos sanguíneos a partir del tejido receptor (Chaves Netto y col, 2009).

El tamaño de poro es un tema que se discute mucho. La matriz desarrollada tiene una estructura esponjosa con poros intercomunicados de 100 a $300 \mu \mathrm{m}$. El tamaño y distribución de los poros de la matriz permiten la penetración de las células MSV$\mathrm{H}$ sembradas con un proceso de agitación continua. Además, el estudio histológico en fase animal de los injertos heterotópicos realizados en la zona inguinal de las ratas atímicas nos permitió observar unas estructuras altamente organizadas que cuando se han contrateñido con Giemsa, nos ha permitido deducir que son vasos que se han formado en el injerto. Con estos resultados, concluimos que el bioimplante desarrollado permite la neovascularización a partir de los tejidos del receptor, ya que la formación de vasos en los injertos ocurre de forma centrípeta, es decir, se realiza desde la periferia hacia el centro del defecto (Chaves Netto y col, 2009). El desarrollo del lecho vascular de los implantes es muy importante, ya que permite el correcto aporte de nutrientes y oxígeno a las células, lo que facilita la formación del nuevo tejido óseo. Sin embargo, los injertos que no se vascularizan se necrosan con el tiempo, ya que la ausencia de nutrientes y oxígeno genera la muerte celular y por consiguiente, la necrosis del injerto realizado (Kawamura y col, 2006). El bioimplante "Biomax" estudiado se ha vascularizado en los estudios animales "in Vivo", lo que nos permite concluir que la porosidad del mismo es adecuada para la penetración y distribución de las células en su interior, y para la formación de un nuevo lecho vascular a partir de los tejidos adyacentes al injerto (Gallego y col, 2010). 
La naturaleza proteica de la matriz, que compone el bioimplante desarrollado en este trabajo, facilita la adhesión celular. El suero utilizado como fuente de albúmina para fabricar la matriz presentan otras proteínas de adhesión como la fibronectina y vitronectina que actúan como moléculas de adhesión celular (Jimi y col, 2012).

La fibronectina es una glicoproteína presente en la matriz extracelular de la mayoría de los tejidos celulares, donde se encuentra en una forma insoluble. Sin embargo, en el plasma y el suero es soluble y circula por la sangre aumentando la coagulación, la cicatrización y la fagocitosis. Presenta una estructura con dominios de unión a colágeno, a algunos proteoglicanos, a glicosaminoglicanos, a fibrina, a heparia y a proteínas de la membrana plasmática celular como las integrinas. Por lo tanto, establece uniones entre moléculas de la matriz extracelular y entre moléculas de las células con la matriz extracelular. La fibronectina desempeña un papel importante en la adhesión de las células a la matriz y actúa como guía de las migraciones celulares que tiene lugar en los embriones de los vertebrados (Lucena y col, 2007). La vitronectina es una glicoproteína abundante en el suero y la matriz extracelular. Esta proteína promueve la adhesión celular porque contiene una secuencia RGD (Arg-Gly-Asp) que es un sitio de unión para las integrinas presentes en la membrana celular. El receptor de vitronectina sirve para anclar las células a la matriz extracelular (Castillo y col, 2005).

Por las características de estas proteínas presentes en la matriz, las células interaccionan con sus receptores y se adhieren a la misma formando el bioimplante. Además, en este punto, la naturaleza proteica de la matriz y su estructura porosa facilita la colonización por células de los tejidos adyacentes, las estimula para la formación de nuevo tejido y permite el crecimiento del hueso en su superficie y/o en su interior a través de los poros interconectados (Albrektsson y col, 2001), por lo que el bioimplante generado es osteoconductivo y osteoinductivo.

El tejido óseo de nueva formación puede generarse a partir de las células indiferencidas o preosteoblastos reclutados de los tejidos adyacentes del receptor o a partir de las células MSV-H incluidas en la matriz. La formación de hueso en un ambiente no condicionado como es el dorso de ratón, se debe a las células 
incluidas en el bioimplante como hemos comprobado con los estudios histológicos realizados con vimentina y osteocalcina humana. Sin embargo, en los defectos críticos mandibulares la formación del nuevo tejido, en un ambiente condicionado, se puede deber a las células MSV-H incluidas en el bioimplante y/o a la diferenciación de las células del hueso receptor, porque como hemos observado en los estudios radiológicos, la densidad ósea es mayor en la periferia que en la zona central del defecto. Estos resultados nos indican que la zona interior del bioimplante presenta más limitaciones para los depósitos minerales que van a formar parte de matriz extracelular del hueso, lo que sugiere que en la fase inicial de la regeneración del defecto generado participan las células derivadas del periostio. El grupo de Oest (2007) han obtenido estos mismos resultados con matrices de Poli (L-láctico-co-D, L-láctico) (PLDL). Sin embargo, por otro lado, Kim y col (2012) en sus trabajos realizados con una matriz dérmica acelular sola o combinada con MSC de tejido adiposo, obtiene una formación de hueso significativamente mayor a las cuatro semanas con matrices conteniendo células, mientras que en los resultados a las 8 semanas no aparecen diferencias significativas. Hay incluso una ligera desigualdad a favor del grupo que presentaba matriz sola. Estos resultados los podríamos extrapolar y pensar que las células incluidas en el bioimplante participan en la formación de hueso inicialmente (Schönmeyr y col, 2009), pero a medida que el injerto se vasculariza y es colonizado por nuevas células osteogénicas, la formación de hueso se debe también a la acción de las células del receptor. Sin embargo, en el trabajo de Gallego y col (2010), los injertos realizados en rata con un bioimplante formado por la matriz de suero con células diferenciadas hacia linaje osteogénico y analizados a las 11 semanas de la cirugía, muestran expresión de vimentina humana dentro y alrededor del bioimplante, con elevada expresión alrededor del hueso de nueva formación (Figura 43). Estos resultados nos indican que la formación del nuevo tejido se debe a la actividad de las células del donante, ya que las células del receptor, en este caso la rata, no muestran actividad para este marcador. Sin embargo, como no se ha realizado un marcador de actividad osteogénica característico de células de rata, no podemos descartar que las células receptoras participen en la regeneración del defecto. 

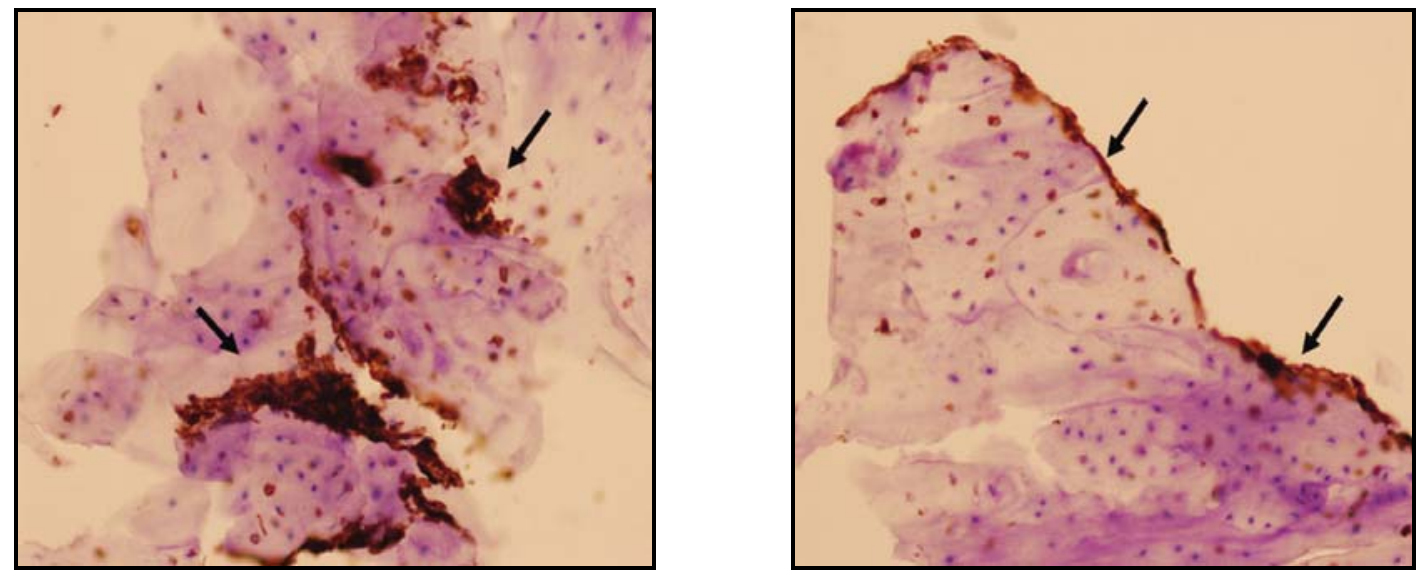

Figura 43. Expresión de vimentina humana en bioimplantes a las 11 semanas de la cirugía, es evidente dentro y alrededor del bioimplante (200X). (Gallego y col, 2010)

Por otro lado, la formación de hueso en los injertos heterotópicos nos sugiere que la matriz aporta estímulos para la transformación de las células mesenquimales presentes en el bioimplante hacia células osteoformadoras y así generar nuevo tejido óseo. Estos estímulos pueden ser físicos, como el estrés mecánico y/o algún tipo de señal eléctrica (Deallera, 1981), o químicos como son los factores de crecimiento que se unen a las células mediante receptores específicos y son capaces de inducir, estimular y fomentar su multiplicación cuando existe una lesión y así reparar el tejido dañado.

Los factores de crecimiento son proteínas solubles producidas y secretadas por las células del organismo, aunque se encuentran en mayor proporción en los gránulos alfa de las plaquetas, en los macrófagos y en el plasma o suero sanguíneo. Entre estos factores destacan las BMPs, que son proteínas formadas por dos cadenas polipeptidicas idénticas que pertenecen a la familia de los factores de crecimiento transformantes TGF- $\beta$. Esta es una superfamilia de proteínas relacionadas con la condrogénesis, osteogénesis y la inducción de tejido conjuntivo. Las BMPs se caracterizan principalmente por su inmenso potencial osteoinductivo, ya que son capaces de promover la formación de hueso nuevo mediante la estimulación de las células osteoprogenitoras para diferenciarse en osteoblastos (Pulido y col, 2013). 
En este punto, los resultados de los ensayos comparativos entre matriz sola, matriz sembrada con células cultivadas 1 día y matriz con células diferenciadas durante 21 días, no muestran diferencias significativas en cuanto a la reparación del defecto, por lo que nos confirman que las propiedades osteoinductivas de la matriz se mantienen en el bioimplante.

Es esencial que las matrices porosas combinadas con células MSC presenten un equilibrio entre las propiedades mecánicas y la compatibilidad biológica para que puedan ser empleadas en ingeniería tisular ósea. Estas matrices deben presentar propiedades mecánicas como el módulo de elasticidad, la resistencia a la tracción, a la fractura, a la fatiga y el porcentaje de elongación, lo más similar posible al tejido que reemplaza, para evitar la osteopenia asociada al uso de implantes óseos (Velasco-Peña 2010).

Los resultados obtenidos en los ensayos "in Vivo" no presentan disminución de la densidad ósea en ningún caso, por lo que podemos concluir que la matriz esponjosa diseñada tiene propiedades mecánicas similares al tejido óseo y mantiene su forma general y la silueta después de la colocación, ya que no precisa ningún tipo de fijación para permanecer en el defecto generado (Gallego y col, 2010).

Finalmente, para que el bioimplante formado cumpla las características para ser ideal, debería ser biodegradable, y en este punto, la naturaleza proteica de la matriz hace que esta se degrade de forma paulatina a medida que se forma el nuevo tejido, observando en los estudios histológicos restos de matriz rodeada del tejido de nueva formación. Las proteínas del suero actúan como agentes quimiotácticos que atraen a los macrófagos para su degradación, al igual que ocurre con los adhesivos biológicos (Rábago Torre y col, 2009; Celis y col, 2014). Además, al ser de origen natural, los productos de la degradación no son tóxicos y se eliminan fácilmente.

Los animales toleraron el procedimiento quirúrgico sin complicaciones. Además, el bioimplante generado se considera biocompatible y de buena tolerancia desde el punto de vista clínico, ya que no tuvo problemas en cuanto a su comportamiento 
biológico. Estos puntos, junto con los resultados de los estudios preclínicos nos permiten concluir que el bioimplante generado por la combinación la matriz tridimensional de suero entrecruzado con células MSV-H diferenciadas es una buena alternativa para la regeneración ósea, lo que nos impulsó a realizar el salto de la investigación al hombre mediante el desarrollo de un ensayo clínico.

\subsection{DISEÑO ENSAYO CLINICO}

El bioimplante "Biomax", es un medicamento de ingeniería tisular. Efectivamente, según el Reglamento (CE) n 1394/2007 del Parlamento Europeo y del Consejo del 13 de noviembre de 2007 se entiende como medicamento de ingeniería tisular aquel que contiene o está formado por células o tejidos manipulados por ingeniería, y que tiene propiedades para regenerar, restaurar o reemplazar un tejido humano. Además, puede contener células o tejidos de origen humano, animal o ambos, y las células pueden ser viables o no.

En nuestro caso, el bioimplante "Biomax" está formado por una matriz de estructura porosa y células MSV-H viables aisladas de hueso esponjoso mandibular. Como hemos visto, la matriz aporta un soporte que guía a las células en su crecimiento y diferenciación para la regeneración tridimensional de los tejidos (Yang y col, 2001). El adecuado diseño del ensayo clínico (EC) es fundamental para el buen desarrollo del mismo (Lazcano-Ponce y col, 2004). Todo EC debe estar justificado y orientado hacia un objetivo principal, correctamente definido y basado en una hipótesis previa (Sacristán y col, 1993) y deben realizarse bajo planteamientos científicos y metodológicos correctos que aseguren la validez de los resultados. Estos serán utilizados para avalar el registro de comercialización del medicamento y servirán en muchos casos como evidencia científica para apoyar la toma de decisiones terapéuticas en la práctica asistencial (Idoate \& Idoipe). El desarrollo de nuevos fármacos, desde los primeros estudios en animales, hasta su comercialización, sigue una serie de etapas en las que el ensayo clínico juega un papel muy importante. La duración del proceso completo es variable, pero el tiempo medio que se tarda en comercializar un nuevo medicamento es de mas de 10 años (Figura 44). 


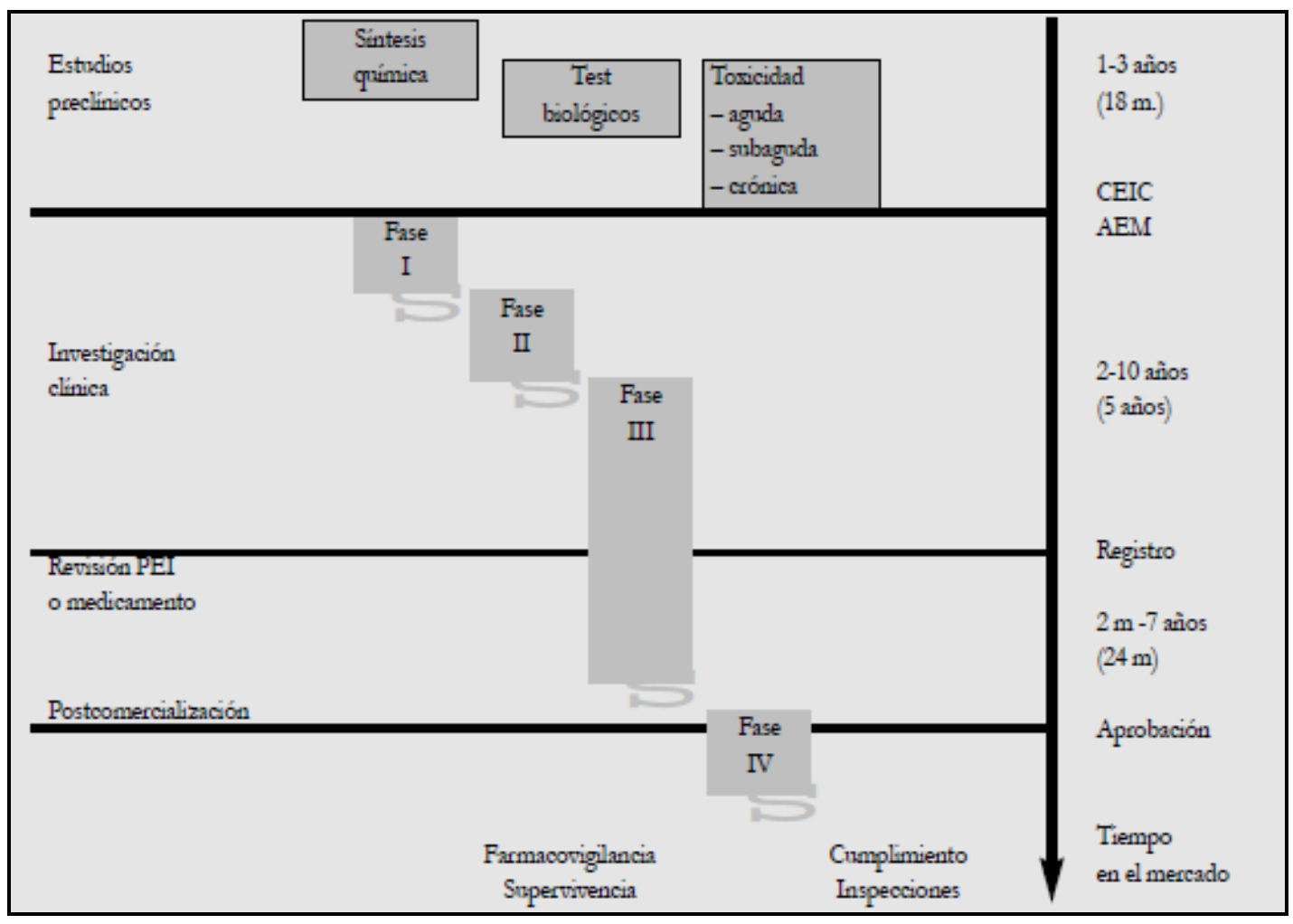

Figura 44. Fases en el desarrollo de un nuevo medicamento (Idoate \& Idoipe)

Se ha desarrollado aquí un EC en fase I/II, que es el primer paso en la investigación de una sustancia o medicamento nuevo en el hombre. Este tipo de ensayos se realizan para comprobar que un fármaco o tratamiento nuevo que demostraron ser seguros para usarse en animales, también pueden administrarse de manera segura en el hombre. Es decir, que proporcionan principalmente información preliminar sobre la factibilidad del procedimiento y la seguridad del producto. En esta fase no se estudia la eficacia del fármaco, ya que se aplica a un grupo reducido de voluntarios, por lo que sólo nos proporcionan información preliminar y nos orientan sobre la pauta de administración más apropiada para ensayos posteriores. En este caso, la vía de administración del nuevo medicamento tiene que ser la misma que vaya a emplearse en el uso clínico posterior, y nunca podrá experimentarse otra vía que no haya sido previamente ensayada en animales (Idoate \& Idoipe). En nuestro caso, la aplicación del bioimplante se realiza buscando la reparación de defectos quísticos maxilares, que dan lugar a defectos óseos equivalentes a los generados en ratas durante la experimentación "in Vivo". Además de la seguridad, el desarrollo de un EC en fase I nos permite comprobar la factibilidad del mismo, es decir, si disponemos de los medios y recursos necesarios para su desarrollo. 
La razón principal para desarrollar un EC en fase I/II, es la observación del efecto que tiene el medicamento a estudio en el organismo, así como el efecto que tiene el organismo sobre el medicamento. A pesar de los buenos resultados obtenidos en los ensayos preclínicos (laboratorio y animales), no podemos predecir los efectos secundarios que este nuevo tratamiento puede tener en los pacientes, ya que no es correcto extrapolar directamente los resultados obtenidos en animales. Existen diferencias de respuesta entre especies y, además, otras reacciones como cefaleas o depresiones son difíciles de determinar en los animales. De aquí que el salto a humanos siempre es un riesgo y para poder optar a la solicitud de un EC tiene que existir un balance beneficio-riesgo positivo (Hollister, 2009).

En la traslación de la investigación básica a la clínica, concurren varios factores: normas de producción, instalaciones, personal y proceso. El propietario de una autorización para fabricar un medicamento de terapia avanzada debe garantizar un sistema que asegure que cada producto y sus componentes puedan ser examinados durante el proceso de obtención, fabricación, empaquetado, almacenado, transporte y entrega; ya sean productos para un EC o para su comercialización. La fabricación de estos productos debe realizarse en un marco legislativo donde las células, genes y tejidos son considerados medicamentos. Por ello se requieren laboratorios específicos de producción de medicamentos de terapia celular donde la calidad del aire está controlada mediante una monitorización de partículas y de calidad microbiológica, como es la Unidad de Producción Celular (UPC) del IBGM. La fabricación de productos de terapia celular estériles está sujeta a requisitos especiales para minimizar los riesgos de contaminación microbiana, de partículas y de pirógenos (Anexo I NCF). El cumplimiento de la normativa GMP asegura que todos los productos autorizados en la unión europea se fabrican siguiendo unas normas de calidad y esto es obigatorio para todos los laboratorios farmacéuticos fabricantes de la Unión Europea. En este punto, la Comisión Europea aprobó dos directivas que establecen principios y directrices de buenas prácticas de fabricación (GMP), la Directiva 2003/94/CE, que se aplica a medicamentos de uso humano y la Directiva 91/412/CEE para los de uso veterinario.

El EC desarrollado en este trabajo es fase I/II abierto y no controlado, con una cohorte de 10 voluntarios que presentaban quistes óseos en la región 
maxilofacial.Se desarrolló en un único centro hospitalario, el HURH de Valladolid, y la fabricación del medicamento bioimplante "Biomax" a estudio se realizó en su totalidad en la UPC del IBGM bajo normativa GMP. El número reducido de pacientes y la participación de un único centro, ha permitido llevar un seguimiento mas detallado y reproducible para detectar cualquier signo de reacción adversa. La elección de un ensayo abierto, donde tanto el investigador como el sujeto conocen el tratamiento, es en este estadio inicial adecuado desde el punto de vista psicológico, ya que el paciente tiene total conocimiento del nuevo tratamiento al que va a ser sometido, y además, facilita la toma de decisiones durante el proceso de selección. Por otro lado, la propuesta de un EC donde no tenemos grupo control, simplifica el diseño pues nos permite aumentar la experiencia en la utilización del bioimplante, evaluar su seguridad y factibilidad, estudiar los efectos secundarios y lo hacen más aceptable desde el punto de vista ético. Sin embargo, en el ensayo no controlado es difícil determinar la eficacia del nuevo tratamiento, pero este no es un objetivo fundamental del EC fase I/II.

La puesta en marcha del EC se inició con el desarrollo de toda la documentación necesaria y que es muy compleja para la obtención de la autorización por parte de las entidades reguladoras. Toda la información preclínica obtenida se incluyó en un dossier denominado "Manual del investigador", que es un punto clave en el desarrollo de la documentación necesaria para el EC junto con el protocolo del ensayo. El objetivo del manual del investigador es proporcionar al personal que participa en el ensayo la información necesaria sobre el medicamento a estudio, dosis, forma de administración y procedimientos para monitorizar la seguridad del producto (BPC).

Una vez elaborados todos los documentos necesarios, el primer paso en la autorización administrativa del EC es el registro en la base de datos europea, con la adjudicación de un número EudraCT. Este número debe ser utilizado para identificar todas las solicitudes de ensayos clínicos dentro del Espacio Económico Europeo y es necesario también en otros documentos relacionados con el ensayo clínico (p.ej. notificaciones de reacciones adversas graves e inesperadas). El número EudraCT está formado por Año, un número secuencial de seis dígitos y un número de control que permite comprobar de manera automática que el número se ha escrito correctamente (AAAA-NNNNNN-CC). El ensayo que nos ocupa es el EudraCT 2010-024246-30. 
El segundo punto es la aprobacióndel protocolo por del Comité Ético en Investigación Clínica (CEIC) y la conformidad de la Dirección del centro donde se va a realizar el EC.

EI CEIC es el primer eslabón en el procedimiento administrativo de autorización de un ensayo clínico con nuevos medicamentos. Está constituido por profesionales sanitarios, principalmente médicos asistenciales entre los cuales debe existir un farmacéutico del hospital y algún miembro del personal de enfermería. Además, debe existir al menos una personal externa al ámbito sanitario, generalmente un licenciado en Derecho, ya que evalúan todos los aspectos generales del EC (metodológicos, éticos y legales). Una vez obtenida la aprobación del CEIC y la conformidad de la Dirección del centro se solicitó la autorización del EC a la AEMPS, que autorizó el desarrollo del EC con la asignación de un número al producto en fase de investigación clínica (PEI). La AEMPS garantiza que tanto los medicamentos de uso humano como los de uso veterinario y los productos sanitarios, cosméticos y productos de higiene personal cumplen con estrictos criterios de calidad, seguridad, eficacia y correcta información con arreglo a la normativa vigente sobre dichas materias en el ámbito estatal y de la Unión Europea. Entre sus competencias destacan evaluar, autorizar, modificar, renovar, restringir, suspender o revocar la autorización de comercialización de los medicamentos de uso humano y veterinario elaborados industrialmente.

La experiencia del equipo investigador en EC previos, el desarrollo del medicamento en la UPC del IBGM, con autorización de la AEMPS para la elaboración de productos de terapia avanzada y la utilización de células MSV autorizadas previamente con el PEI 10/134, han agilizado los trámites para la autorización administrativa del EC desarrollado en este trabajo. La utilización de células autólogas para el tratamiento de defectos maxilofacionales es de gran aceptación en los EC (Meyer y col, 2006), ya que evita todo tipo de reacción inmunológica. Esto también ha facilitado la autorización del EC.

En un futuro sería deseable poder realizar la terapia celular con células alogénicas. Se simplificaría el procedimiento y se abaratarían los costes de producción. El mayor inconveniente en la utilización de tratamientos alogénicos, sería la posibilidad de rechazo inmunológico. Sin embargo, se ha encontrado que este tipo celular evade el reconocimiento antigénico e inhiben las respuestas inmunes de una manera no restringida por el sistema HLA, lo que conduce a la tolerancia 
inmunológica (Aggarwal y col, 2005; Sotiropoulou y col, 2007; Machado y col, 2013). La fabricación de un bioimplante alogénico es nuestro nuevo objetivo para un futuro EC.

\section{RESULTADOS DEL ENSAYO CLÍNICO}

El desarrollo del EC actual ha demostrad su factibilidad y seguridad. El único incnveniente de entidad ha sido la carga baceriana inicial de las muestras, que se ha solucionado con el periodo de cuarentena establecido. No se ha observado inflamación, dolor, fiebre o infección, ni signos de rechazo en ninguno de los pacientes intervenidos, lo que nos indica que el medicamento a estudio es seguro en esta primera fase de investigación clínica.

La formación de hueso nuevo para restaurar su función tras un traumatismo, un daño o una pérdida es una de las mayores necesidades clínicas y socioeconómicas. En este punto, la ingeniería tisular ósea es la estrategia alternativa del siglo XXI, ya que combina las herramientas básicas: matriz, células y factores de crecimiento para la reparación o regeneración del tejido dañado (Hutmacher y col, 2007). Las lesiones quísticas maxilares son de elevada incidencia en el territorio maxilo-facial, ya que generan defectos en los maxilares, considerados huesos únicos en el esqueleto por su íntima relación con los dientes y las estructuras faciales. En principio, el quiste es asintomático, solo se aprecia por procedimientos radiográficos; pero su evolución tiene consecuencias importantes como la pérdida de hueso y piezas dentarias.

El tratamiento actual de las lesiones quisticas consiste en la ostectomía, enucleación del quiste y el relleno de la cavidad residual con biomateriales homólogos, heterólogos o sintéticos. En muchas ocasiones, un defecto no tratado con métodos de regeneración ósea (relleno con biomateriales y técnicas de regeneración ósea guiada) implica una insuficiente o nula posibilidad de rehabilitación protésica fija para el paciente por pérdida de volumen óseo (VelascoPeña 2010). Esto supone por ejemplo, la imposibilidad de sustituir las piezas dentarias perdidas por implantes. El objetivo actual del tratamiento clínico debe asegurar no sólo el de la patología quística subyacente sino el asegurar un criterio clínico-radiológico de regeneración del hueso perdido, ya que los defectos óseos mandibulares requieren una construcción que garantice no sólo un resultado estético sino también el funcional. 
La biología de la reparación del hueso requiere una señal osteoinductiva, una respuesta del huésped, una matriz y un adecuado aporte vascular (Peterson y col, 2005). El hueso autólogo es el "gold standard" como material de relleno para el tratamiento de defectos óseos (Hennessey y col, 2005; Meyer y col, 2006; InfanteCossio y col, 2007), ya que es osteoinductivo (libera factores de crecimiento), osteogénico (posee células osteoformadoras) y osteoconductivo (permite la vascularización) (Dimitriou y col, 2011; Cab Chan, 2014). Sin embargo, la morbilidad asociada en la zona donante (Younger y col, 1989) y la limitación de cantidad en cuanto a la escasez de zonas donantes, hace que se busquen opciones más sencillas, fundamentalmente en el campo de la ingeniería tisular donde se encuadraría el bioimplante "Biomax".

Durante el desarrollo de un EC el paciente debe ser informado del tipo de biomaterial que se va a utilizar para el relleno de la cavidad residual ósea. La preferencia de utilizar un tipo de biomaterial u otro depende de la aceptación del paciente, experiencia del cirujano y disponibilidad del mismo. Por otra parte, el creciente nivel educativo de nuestra población otorga al paciente un papel activo, junto con el cirujano, a la hora de decidir las posibilidades reparativas existentes. En este punto, existe una la demanda creciente de productos autólogos que minimizan la transmisión de enfermedades.

El bioimplante "Biomax" es fabricado en su totalidad de forma autóloga. Además, la conjunción de las células MSC (MSV-H) con los factores osteoinductivos liberados por la matriz de suero, está considerado como el método más eficaz para la reparación de los defectos óseos. (Peterson y col, 2005). La matriz de suero sanguíneo del paciente proporciona un soporte autólogo, totalmente biocompatible, reabsorbible y de fácil manejo, en el que las células madre mesenquimales (MSVH) cumplen su papel de regeneración y reparación del tejido óseo afectado, lo que podría llegar a ser una estrategia exitosa en la búsqueda de una alternativa para la regeneración de los defectos quísticos maxilares. Las MSC poseen efectos antiapoptóticos, efecto inmunoregulador (Duffy y col, 2011; Motespan y col, 2014) y además, estimulan la migración de las células del huésped hacia el interior de la matriz, por lo que realizan una acción "indirecta" en la vascularización a partir del tejido receptor. Estas características las hace ser esenciales en los procesos de ingeniería tisular para la reparación de defectos óseos (Jones y col, 2011). En este punto destacamos la utilización de células autólogas (Meyer y col, 2006) a partir de una fuente fácilmente accesible, como es el hueso mandibular. 
El tratamiento de 9 pacientes con el bioimplante "Biomax" como material de relleno de las cavidades ósea residuales tras al enucleación del quiste mandibular ha sido un tratamiento seguro, ya que no se ha registrado ningún tipo de reacción adversa, y además, el bioimplante presentó un buen comportamiento biológico, ya que no generó inflamación tras su aplicación.

El desarrollo de un ensayo no controlado, no nos permite demostrar concluyentemente la eficacia del tratamiento, ya que no tenemos grupo control para comparar y calcular la significación estadística. Para paliar en esta parte esta deficiencia se ha realizado un estudio comparativo entre la zona afectada por el defecto quístico y tratada con el bioimplante y de una zona sana de hueso reticular del mismo paciente. En ambos casos se ha determinado la diferencia de densidad en la tomografía computerizada en ambas zonas antes y después del tratamiento.

El grupo experimental (quiste) que ha recibido el tratamiento con el bioimplante "Biomax" presenta un aumento de densidad ósea significativo pues el valor final es, en promedio, un $252 \%$ mayor que el valor obtenido antes del tratamiento, estadísticamente significativo $(p<0.004$; Tabla 15). En todos los pacientes sin excepción hay un aumento de densidad, y este aumento de densidad parece mayor en los bordes del quiste, aunque esto es difícil de cuantificar. En este punto y por razones obvias, no se pueden realizar estudios histológicos en el paciente para determinar el origen de las células que participan en la reparación del tejido. Además, no sería posible por que, al utilizar de MSV-H autólogas no es posible diferenciar entre las células del periostio de las células incluidas en el bioimplante. Lo que si puede concluirse es que la utilización del bioimplante como material de relleno estimula la formación de tejido óseo que contribuye a la reparación del defecto quístico mandibular, bien sea mediado por las células MSV-H del bioimplante y/o por la estimulación de las células presentes en el periostio del tejido receptor. En las zonas control de hueso reticular no hubo, en promedio, crecimiento de hueso, ya que el cociente de densidad ósea después/antes del tratamiento fue de 0.99 (Tabla 15). El examen individual de los 9 pacientes muestra que, sólo aparece formación de tejido en uno de los nueve pacientes analizados. La diferencia entre ambos grupos, experimental (quistes) y control fue muy significativa $(P<0.001)$. 
En resumen, todos los resultados obtenidos nos confirman que el bioimplante "Biomax" es un tratamiento prometedor para tratar los defectos quísticos mandibulares y, por extensión, las pérdidas de sustancia óseas; ya que como hemos visto a lo largo de este trabajo, el bioimplante posee las características para ser considerado "ideal": biocompatible, poroso, osteoinductivo, osteoconductivo, con propiedades mecánicas similares al hueso y biodegradable. Además, se puede obtener fácilmente de forma autóloga. Aunque hay algunos antecedentes en animales, no hemos sido capaces de encontrar antecedentes de tratamientos de ingeniería de tejidos similares en humanos. En definitiva, el tratamiento descrito aquí puede considerarse novedoso y prometedor para la reparación de defectos óseos, ya que favorece la formación de hueso, sin que se hayan registrado acontecimientos adversos significativos. Nuestra opinión, sin embargo, es que los ensayos deben continuarse y que, en el punto que estamos sería conveniente desarrollar un EC fase II controlado, donde podamos valorar directamente la eficacia de Biomax en comparación con un tratamiento convencional. Un problema serio son los elevados costes de fabricación del bioimplante bajo normativa GMP, lo que hace que nos decantemos por un producto de origen alogénico para en el nuevo ensayo; de esta forma se facilitaría la logística y se abaratarían los costes de fabricación, con lo que aumentaría el número de pacientes susceptibles de utilizar este tratamiento. 
CONCLUSIONES 



\section{CONCLUSIONES}

Las conclusiones obtenidas durante de este estudio son las siguientes:

1. Las células MSV-H aisladas a partir de esquirlas de hueso mandibular bajo normas de correcta fabricación en la Unidad de Producción Celular del IBGM de Valladolid cumplen los principales criterios recomendados por la Sociedad internacional de Terapia Celular (ISCT) para identificarlas realmente como células mesenquimales.

2. La matriz tridimensional fabricada a partir de suero autólogo en la sala de liofilización de la UPC del IBGM autorizada por la AEMPS tiene la calidad exigida por las normas de correcta fabricación (GMP), por lo tanto, permite en asociación con las células MSV-H la fabricación del bioimplante "Biomax", considerado un medicamento de ingeniería tisular.

3. Los resultados obtenidos de los estudios preclínicos "in Vitro" e "in Vivo" nos permiten concluir que la combinación de las células MSV-H unidas a la matriz de suero entrecuzado y prediferenciadas hacia linaje osteogénico dan lugar a un bioimplante biocompatible, seguro y biodegradable.

4. Estas características "ideales" hacen que Biomax sea una opción prometedora para la regeneración ósea, lo que justifica el desarrollo del ensayo clínico en humanos. En consecuencia se plantea un ensayo fase I-II, intervencionista, abierto, con 10 pacientes que presentan quistes óseos en la región máxilofacial y un seguimiento de 12 meses.

5. Los resultados del ensayo clínico desarrollado en este trabajo permiten concluir que ha sido factible, ya que se han concluido todas las fases del mismo sin mayores complicaciones. El ensayo demuestra también que el bioimplante "Biomax" es un medicamento seguro, ya que no se ha registrado ningún tipo de reacción adversa.

6. La comparación de densidades entre la zona tratada y una zona de hueso reticular sano del mismo paciente, nos permiten concluir que el tratamiento realizado con el bioimplante Biomax ha sido efectivo para los defectos quísticos mandibulares tratados en este ensayo clínico. 

BIBLIOGRAFIA 

ABAD M, MOSTEIRO L, PANTOJA C, CAÑAMERO M, RAYON T, ORS I, GRAÑA O, MEGÍAS D, DOMÍNGUEZ O, MARTÍNEZ D, MANZANARES M, ORTEGA S \& SERRANO M (2013) Reprograming in vivo produce teratomas and iPS cells with totipotency features. Nature 502: 340-345.

ABARRATEGI A, LÓPIZ-MORALES Y, RAMOS V, CIVANTOS A, LÓPEZ-DURÁN L, MARCO F\& LÓPEZ-LACOMBA JL (2010) Chitosan scaffolds for osteochondral tissue regeneration. J Biomed Mater Res A. 95(4):1132-1141.

AGGARWAL S \& PITTENGER MF (2005) Human mesenchymal stem cells modulate allogeneic immune cell responses. Blood 105(4): 1815-1822.

AGHA-HOSSEINI F, JAHANI MA, JAHANI M, MIRZAII-DIZGAH I \& ALIMOGHADDAM K (2010) In vitro isolation of stem cells derived from human dental pulp. Clin Transplant 24: E23-E28

AKINTOYE SO, LAM T, SHI S, BRAHIM J, COLLINS MT \& ROBEY PG (2006) Skeletal site-specific characterization of orofacial and crest human bone marrow stromal cells in same individuals. Bone 38: 758-768.

AKIYAMA K, YOU Y-O, YAMAZA T, CHEN C, TANG L, JIN Y, CHEN X-D, GRONTHOS S \& SHI S (2012) Characterization of bone marrow derived mesenchymal stem cells in suspension. Stem Cell Research \& Therapy 3: 40-53.

AKIYAMA MA \& NAKAMURA M (2009) Bone Regeneration and Neovascularization Processes in a Pellet Culture System for Periosteal Cells. Cell Transplantation 18: 443452.

ALBREKTSSON T, BRÅNEMARK PI, HANSSON HA \& LINDSTRÖM J (1981) Osseointegrated titanium implants. Requirements for ensuring a long-lasting, direct bone-to-implant anchorage in man. Acta Orthop Scand 52(2): 155-170.

ALBREKTSSON T \& JOHANSSON C (2001) Osteoinduction, osteoconduction and osseointegration. Eur Spine J 10 Suppl 2: S96-101.

ALKHALIL M, SMAJILAGIC A\& REDZIC A (2015) Human dental pulp mesenchymal stem cells isolation and osteoblast differentiation. Med Glas (Zenica) 12(1):27-32.

ANKRUM JA, ONG JF \& KARP JM (2014) Mesenchymal stem cells: immune evasive, not immune privileged. Nature Biotechnlogy 32 (3):252-260,

ARIAS ME \& FELMER R (2009) Biology of embryonic stem cells (ES cells) in different species: potential aplications in biomedicine. Arch Med Vet 41: 185-195.

ARTHUR A, ZANNETTINO A \& GRONTHOS S (2009) The Therapeutic Applications of Multipotential Mesenchymal/Stromal Stem Cells in Skeletal Tissue Repair. J. Cell. Physiol 218: 237-245.

AUF'MKOLK B, HAUSCHKA PV \& SCHWARTZ (1985) Characterization of Human Bone Cells in Culture. Calcif Tissue Int 37: 228-235

BARONE A, NICOLI N, FINI M, GIARDINO R, CALVO JL \& COVANI U(2008) . Xenograft versus extracción alone for ridge preservation after tooth removal: a clinical and histomorphometric study. J Periodontol. 79(8): 1370- 77. 
BARRETT R, ORNELAS L, YEAGER N, MANDEFRO B, SAHABIAN A, LENAEUS L, TARGAN SR, SVENDSEN CN \& SAREEN D (2014) Reliable generation of induced pluripotent stem cells from human lymphoblastoid cell lines. Stem Cells Transl Med. 3(12):1429-1434.

BASCONES A \& MORANTE S (2006). Antisépticos orales. Revisión de la literatura y perspectiva actual. Av Periodon Implantol 18(1): 31-59.

BLACKWOOD KA, BOCK N, DARGAVILLE TR \& WOODRUFF MA (2012) Review Article Scaffolds for Growth Factor Delivery as Applied to Bone Tissue Engineering. International Journal of Polymer Science 2012:1-25.

BECERRA J, ANDRADES JA, SANTAMARÍA JA, CIFUENTES M \& GUERADO E (2001) Bone regeneration, cell therapy and tissue engieneering. Med Clin (Barc) 116: 23-34.

BEGLEY CT, DOHERTY MJ, HANKEY DP \& WILSON DJ (1993) The culture of human osteoblasts upon bone graft substitutes. Bone 14:661-666.

BERESFORD JN, GALLAGHER JA, POSER JW \& RUSSELL RG (1984) Production of osteocalcin by human bone cells in vitro. Effects of 1,25(OH)2D3, 24,25(OH)2D3, parathyroid hormone, and glucocorticoids. Metab Bone Dis Relat Res 5(5):229-234.

BEYER NN\& DA SILVA ML (2006) Mesenchymal stem cells: isolation, in vitro expansion and characterizacion. Handb Exp Pharmacol 174: 249-282.

BOSE S, DARSELL J, HOSICK HL, YANG L, SARKAR DK \& BANDYOPADHYAY A (2002) Processing and characterization of porous alumina scaffolds.J Mat Sci: Mat in Med 13 (1): 23-28.

BOZAL CB (2006) Biología del Osteocito. Actualiz Osteología 2(1):19-21.

BRITO-PEREIRA CM, LEITE FIGUEIREDO ME, CARVALHO R, CATRE D \& ASSUNCIÓN JP (2012) Anestesia y Colgajos Microvascularizados. Rev Bras Anestesiol 62 (4): 1-10.

BRUDER SP, JAISWAL N, HAYNESWORTH SE (1997) Growth kinetics, self-renewal, and the osteogenic potential of purified human mesenchymal stem cells during extensive subcultivation and following cryopreservation. J Cell Biochem 64(2):278-294

BURG KJ, PORTER S \& KELLAM JF (2000) Biomaterial developments for bone tissue engineering. Biomaterials 21(23): 2347-2359.

BURG KJL, HOLDER WD, CULBERSON CR, BEILER RJ, GREENE KG, LOEBSACK AB, ROLAND WD, EISELT P, MOOEY DJ \& HALBERSTADT CR (2000) Comparative study of seeding for three-dimensional polymeric scaffolds. J Biomed Mater Res 51(4):642-9.

CAB CHAN E (2014). Sustitutos de tejido óseo. Orthotips 10(4): 208-217.

CAO B, LI Z, PENG R \& DING J (2015) Effects of cell-cell contact and oxygen tension on chondrogenic differentiation of stem cells. Biomaterials 64: 21-32. 
CASTILLO MRR \& RAMIREZ YAL (2005) Purificacion de vitronectina humana pra la obtencion de antisuero antivitronectina. Arch Med 1(3).

CELIS J, MESA D, AVENDAÑO E \& GONZÁLEZ-VALLE F (2014) Intracameral fibrin glue in spontaneous corneal perforation. Arch Soc Esp Oftalmol 89(3): 124-126.

CHAVES NETTO HDM, OLATE S, CHAVES MMGA, BARBOSA AJR \& MAZZONETTO R (2009) Histological Analyses of Osseous Repair Defects. Recognized of Critic Defects. Int J Morphol 27(4): 1121-1127.

CHEN G, USHIDA T \& TATEISHI T (2002) Scaffold Design for Tissue Engineering Macromol Biosci. 2: 67-77.

CHEN Y, SHAO JZ, XIANG LX, DONG XJ \& ZHANG GR (2008) Mesenchymal stem cells: A promising candidate in regenerative medicine. Int J Biochem Cell Biol 40: 815820.

CHUNG CH, GOLUB EE, FORBES E, TOKUOKA T \& SHAPIRO IM (1992) Mechanism of action of beta-glicerophosphate on bone cell mineralization. Calcif Tissue Int 51(4): 305-311.

CHUAIRE-NOACK L, RONDÓN-LAGOS S, SÁNCHEZ-CORREDOR M, IBÁÑEZPINILLA M \&RAMÍREZ-CLAVIJO S (2010) $\beta$-Galactosidase activity as a marker of senescence in primary cultures of the ovarian surface epithelium. Invest Clin 51(3): 351-367.

CICUÉNDEZ M, IZQUIERDO-BARBA I, SÁNCHEZ-SALCEDO S, VILA M \& VALLETREGÍ M (2011) Biological performance of hydroxyapatite-byopolymer foams: In vitro cell response. Acta Biomaterialia 8: 802-810.

CLAROS S, RODRIGUEZ-LOSADA N, CRUZ E, GUERADO E, BECERRA J \& ANDRADES AJ (2012) Characterization of Adult Stem/ Progenitor Cell Populations From Bone Marrow in a Three-Dimensional Collagen Gel Culture System. Cell Transplantation 21: 2021-2032.

CLOSE B, BANISTER K, BAUMANS V, BERNOTH EM, BROMAGE N, BUNYAN J, ERHARDT W, FLECKNELL P, GREGORY N, HACKBARTH H, MORTON D \& WARWICK C (1996) Recommendations for euthanasia of experimental animals: Part 1. Lab Anim 30(4): 293-316.

CLOSE B, BANISTER K, BAUMANS V, BERNOTH EM, BROMAGE N, BUNYAN J, ERHARDT W, FLECKNELL P, GREGORY N, HACKBARTH H, MORTON D \& WARWICK C (1997) Recommendations for euthanasia of experimental animals: Part 2. Lab Anim. 31(1): 1-32.

COBO F, NAVARRO JM, HERRERA MI, VIVO A, PORCEL D, HERNÁNDEZ C, JURADO M, GARCÍA-CASTRO J \& MENÉNDEZ P (2008) Electron microscopy reveals the presence of viruses in mouse embryonic fibroblasts but neither in human embryonic fibroblasts nor in human mesenchymal cells used for hESC maintenance: toward an implementation of microbiological quality assurance program in stem cell banks. Cloning Stem Cells 10(1):65-74. 
COLLETTI G, AUTELITANO L, RABBIOSI D, BIGLIOLI F, CHIAPASCO M, MANDALÀ M \& ALLEVI F (2014) Technical refinements in mandibular reconstruction with free fibula flaps: outcome-oriented retrospective review of 99 cases. Acta otorhinolaryngologicaitalica 34:342-348.

DEALLER SF (1981) Electrical phenomena associated with bones and fractures and the therapeutic use of electricity in fracture healing. J Med Eng Technol 5(2): 73-79.

DEANS RJ \& MOSELEY AB (2000) Mesenchymal stem cells: Biology and potential clinical uses. Experimental Hematology 28: 875-884.

DE LA PEÑA VARELA G. Tesis doctoral. Regeneración ósea mandibular con células osteogénicas sembradas en una matriz protéica obtenida a partir de albúmina plasmática: estudio de ingeniería tisular ósea en ratas inmunoincompetentes.

DESAI N, RAMBHIA P \& GISHTO A (2015) Human embryonic stem cell cultivation: historical perspective and evolution of xeno-free culture systems. Reproductive Biology and Endocrinology 13 (9): 1-15.

DETSCH R, ALLES SHUM J, WESTENBERGER P, SIEKER F, HEUSINGER D, KASPER C \& BOCCACCINI AR (2015) Osteogenic differentiation of umbilical cord and adipose derived stem cells onto highly porous $45 S 5$ Bioglass $®$-based scaffolds. $J$. Biomedical Materials Research 103A (3):1029-1037.

DIMITRIOU R, JONES E, MCGONAGLE D \& GLANNOUDIS PV (2011).Bone regeneration: current concepts and future directions. BMC Med 9: 66-76.

DIRECTIVA 2003/94/CE de la comisión de 8 de octubre de 2003

DROSSE I, VOLKMER E, CAPANNA R, DE BIASE P, MUTSCHIER W \& SCHIEKER M (2008) Tissue engineering for bone defect healing: An update on a multi-component approach. Int. J. Care Injured 3952: 9-20.

DOMINICI M;, LE BLANC K, MUELLER I, SLAPER-CORTENBACH I, MARINI F, KRAUSE D, DEANS R, KEATING A, PROCKOP DJ \& HORWITZ E (2006).. Minimal criteria for defining multipotent mesenchymal stromal cells. The International Society for Cellular Therapy position statement. Cytotherapy. 8(4):315-317.

DOUCET C, ERNOU I, ZHANG Y, LLENSE JR, BEGOT L, HOLY X \& LATAILLADE JJ (2005) Platelet Lysates Promote Mesenchymal Stem Cell Expansion: A Safety Substitute for Animal Serum in Cell-Based Therapy Applications Journal of Cellular Physiology 205: 228-236.

DUFFY MM, RITTER T, CEREDIG R \& GRIFFIN MD (2011) Mesenchymal stem cell effects on T-cell effector pathways. Stem Cell Res Ther 2(4): 34-43

DULAMEA AO (2015) .The potential use of mesenchymal stem cells in stroke therapyfrom bench to besides. J Neurol Sci 15: 145-148.

EISELLEOVA L, PETERKOVA I, NERADIL J, SLANINOVA I, HAMPL A \& DVORAK P (2008) Comparative study of mouse and human feeder cells for human embryonic stem cells. Int. J. Dev. Biol. 52: 353-363. 
ENRILE DE ROJAS FJ \& SANTOS-ALEMANY A (2005) Mouthrinses with evidencebased control of plaque and gingivitis. RCOE 10(4): 445-452.

EVANS MJ \& KAUFMAN MH (1981) Establisment in culture of pluripotencial cells from mouse embryos. Nature 292: 154-156.

FALKE G \& ATALA A (2000) Reconstrucción de tejidos y órganos utilizando Ingeniería Tisular. Arch. Argent.Pediatr 98 (2): 103-115.

FERNANDEZ DOVAL JA. Tesis doctoral. Regeneración ósea mandibular mediante cultivo de células mesenquimales mandibulares humanas sobre matriz proteica obtenida a parttir de albúmina plasmática: estudio experimental de ingeniería tisular ósea en ratas atímicas

FERNÁNDEZ-TREGUERRES-HERNÁNDEZ-GIL I, ALOBERA-GARCÍA MA, DEL CANTO-PINGARRÓN M \& BLANCO-JERÉZ L (2006) Physiological bases of bone regeneration I. Histology and physiology of bone tissue. Med Oral Patol Oral Cir Bucal 11: E47-E51.

FERNÁNDEZ-TREGUERRES-HERNÁNDEZ-GIL I, ALOBERA-GARCÍA MA, DEL CANTO-PINGARRÓN M \& BLANCO-JERÉZ L (2006) Physiological bases of bone regeneration II:The remodeling process. Med Oral Patol Oral Cir Bucal 11: E151-E157.

FERNÁNDEZ VALLONE VB, ROMANIUK MA, CHOI H, LABOVSKY V \& OTAEGUI J (2013) Mesenchymal stem cells and their use in therapy: What has been achieved? Differentiation 85: 1-10.

FERRERO-GUTIERREZ A, MENENDEZ-MENENDEZ Y, ALVAREZ-VIEJO M, MEANA A \& OTERO J (2013) New serum-derived albumin scaffold seeded with adipose-derived stem cells and olfactory ensheathing cells used to treat spinal cord injured rats. Histol Histopathol 28: 89-100.

FREYMAN TM, YANNAS IV \& GIBSON LJ (2001) Cellular materials as porous scaffolds for tissue engineering. Progress in Materials Science 46:273-282.

FRIEDENSTEIN AJ, PIATETZKY-SHAPIRO I \& PETRAKOVA KV (1966) Osteogenesis in transplants of bone marrow cells. J. Embryol. exp. Morph 16(3): 581390.

FRÖHLICH M, GRAYSON WL, WAN LQ, MAROLT D, DROBNIC M \& VUNJAKNOVAKOVIK G (2008) Tissue Engieneeres Bone Grafts: Biological Requirements, Tissue Culture and Clinical Relevance. Curr Stem Cell Res Ther 3(4): 254-264.

GALLEGO L. Tesis Doctoral: Desarrollo mediante cultivo in vitro de osteoblastos mandibulares humanos sobre matriz proteica tridimensional. Análisis del comportamiento in vivo en animales inmunoincompetentes. Oviedo 2009

GALLEGO L, JUNQUERA L, MEANA A, ALVAREZ-VIEJO M \& FRESNO M (2010) Ectopic bone formation from mandibular osteoblasts cultures in a novel human serumderived albumin scaffold. J Biomater Appl 25(4): 367-381.

GALLEGO L, JUNQUERA L, MEANA A, GARCIA E \& GARCIA V (2010) Threedimensional culture of mandibular human osteoblasts on a novel albumin scaffold: growth, proliferation, and differentiation potential in vitro. Int J Oral Maxillofac Implants 25(4): 699-705. 
GALLEGO L, JUNQUERA L, GARCIA E, GARCIA V, ALVAREZ-VIEJO M, COSTILLA S, FRESNO MF \& MEANA A (2010) Repair of Rat Mandibular Bone Defects by Alveolar Osteoblasts in a novel Plasma-Derived Albumin Scaffold. Tissue Engineering Part A 16(4): 1179-1187.

GNECCHI M, DANIELI P \& CERVIO E (2012) Mesenchymal stem cell therapy for heart disease. Vascular Pharmacology 57: 48-55.

GODBEY WT, STACEY HINDY BS, SHERMAN ME \& ALATA A (2004) A novel use of centrifugal force for cell seeding into porous scaffolds. Biomaterials 25: 2799-2805.

GOLDSTEIN AS, JUAREZ TM, HELMEKE CD, GUSTIN MC \& MIKOS AG (2001). Effect of convection on osteoblastic cell growth and function in biodegradable polymer foam scaffolds. Biomaterials 22: 1279-1288.

GONZÁLEZ DE TORRE I, QUINTANILLA L, PINEDO-MARTÍN G, ALONSO M \& RODRÍGUEZ-CABELLO JC (2014) Nanogel formation from dilute solutions of clickable elastin-like recombinamers and its dependence on temperature: two fractal gelation modes. ACS Appl Mater Interfaces 6(16): 14509-14515.

GONZÁLEZ M, ARTEAGA-VIZCAÍN M,BENITO M \& BENITO M (2012) Application of platelet rich plasma (PRP) and its derivativesin dental implantologie and plastic surgery. Invest Clin 53(4): 408-418.

GRAYSON WL, BUNNELL BA, MARTIN E, FRAZIER T, HUNG BP \& GIMBLE JM (2015) Stromal cells and stem cells in clinical bone regeneration. Nat Rev Endocrinol 11 (3): 140-150.

GRIFFIN MD, RITTER T \& MAHON BP (2010) Immunological Aspects of Allogenic Mesenchymal Stem Cell Therapies. Human Gene Therapy 21: 1641-1655.

GRIFFITHS S, BARANIAK PR, COPLAND IB, NEREM RM \& MCDEVITT TC (2013). Human platelet lysate stimulates high-passage and senescent human multipotent mesenchymal stromal cell growth and rejuvenation in vitro. Cytotherapy 15: 14691483.

GUTIERREZ-ARANDA I, RAMOS-MEJIA V, BUENO C, MUNOZ-LOPEZ M, REAL PJ, MACIA A, SANCHEZ L, LIGERO G, GARCIA-PAREZ JL \& MENENDEZ P (2012) Human induced pluripotent stem cells develop teratoma more efficiently and faster than human embryonic stem cells regardless the site of injection. Stem Cells 28: 1568-1570.

HABIBOVIC P \& DE GROOT K (2007) Osteoinductive biomaterials--properties and relevance in bone repair. J Tissue Eng Regen Med.1(1):25-32.

HANDSCHEL J, WIESMANN H-P, DEPPRICH R, KÜBLER NR \& MEYER U (2006) Cell-based Bone Reconstruction Therapies-Cell Sources. Int J Oral Maxillofac Implants 21:890-898.

HELMY KY, PATEL SA, SILVERIO K, PLINER L \& RAMESHWAR P (2010) Stem cells and regenerative medicine: accomplishments to date and future promise. Therapeutic Delivery 1: 693-705. 
HEMEDA H, GIEBEL B \& WAGNER W (2014) Evaluation of human lysate versus fetal bovine serum for culture of mesenchymal stromal cells. Cytotherapy 16: 170-180.

HENNESSEY JW, LÓPEZ NORIEGA JC \& SÁMANO OSUNAII IJ (2005) Uso del injerto autógeno en la reconstrucción de defectos óseos de la región maxilofacial: Casos clínicos. Revista Odontológica Mexicana 9(2): 97-106, 2005.

HERNÁNDEZ-FLORES C, DELGADO A \& DOMÍNGUEZ-HERNÁNDEZ VM (2011) Evaluación biomecánica de un modelo de defecto óseo en tibia de rata. Revista Mexicana de Ingeniería Biomédica 22(1): 12-19.

HERNÁNDEZ S (2006) El modelo animal en las investigaciones biomédicas. Biomedicina 2 (3): 252-256.

HOLLISTER SJ (2009) Scaffol engineering: a bridge to where? Biofabrication 1: 1-14.

HORWITZ EM, GORDON PL, KOO WKK, MARX JC, NEEL MD, MCNALL RY, MUUL L \& HOFMANN T (2001) Isolated allogenic bone marrow-derived mesenchymal cells engraft and stimulated growth in childrem with osteogenesis imperfecta: Implications for cell therapy of bone. PNAS 99: 8932-8937.

HORWITZ EM, LE BLANC K, DOMINICI M, MUELLER I, SLAPER-CORTENBACH I, MARINIF.C, DEANS RJ, KRAUSE DS \& KEATING A (2005) Clarification of the nomenclature for MSC: The International Society for Cellular Therapy position statement. Cytotherapy 7(5):393-395.

HUANG GTJ, GRONTHOS S \& SHI S (2009). Mesenchymal Stem Cells Derived from Dental Tissues vs. those from Other Sources: Their Biology and Role in Regenerative Medicine. J. Dent Res 88(9): 792-806

HUTMACHER DW, SCHANTZ JT, XU FU LAM C, CHENG TAN K \& CHYE LIM T (2007) State of the art and future directions of scaffold-based bone engineering from a biomaterials perspective. J Tissue Eng Regen Med 1(4):245-60.

IDOATE A \& IDOIPE Á. Farmacia Hospitalaria 2.4. Investigación y ensayos clínicos.

IKADA Y (2006). Challenges in tissue engineering. J. R. Soc. Interface 3: 589-601.

ILIZAROV GA (1989) The tension-stress effect on the genesis and growth of tissues. Part I. The influence of stability of fixation and soft-tissue preservation. Clin Orthop Relat Res 238: 249-2819.

ILIZAROV GA (1989). The tension-stress effect on the genesis and growth of tissues. Part II. The influence of the rate and frequency of distraction. Clin Orthop Relat Res 239: 263-285.

INFANTE-COSSÍO P, GUTIÉRREZ-PÉREZ JL, TORRES-LAGARES D, GARCÍAPERLA GARCÍA A \& GONZÁLEZ-PADILLA JD (2007) Bone cavity augmentation in maxillofacial surgery using autologous material. Rev Esp Cir Oral y Maxilofac 29,1:7-19

JAISWAI N, HAYNESWORTH SE, CAPLAN AI \& BRUDER SP (1997) Osteogenic differentiation of purified, culture-expanded human mesenchymal stem cells in vitro. $J$. Cell Biochem 64: 295-312. 
JANSEN JA, VEHOF JWM ,RUHÉ PQ, KROEZE-DEUTMAN H, KUBOKI Y, TAKITA H, HEDBERG EL \& MIKOS AG (2005) Growth factor-loaded scaffolds for bone engineering. Journal of Controlled Release 101 (1-3): 127-136.

JONES E \& YANG X (2011) Mesenchymal stem cells and bone regeneration: Current status. Injury, Int J Care Injured 42: 562-568.

JONES SJ \& BOYDE A (1977) The migration of Osteoblast. Cell Tiss Res 184: 179193.

JORI FP, NAPOLITANO MA, MELONE MA, CIPOLLARO M, CASCINO A, ALTUCCI L, PELUSO G, GIORDANO A AND\& GALDERISI U (2005) Molecular pathways involved in neural in vitro differentiation of marrow stromal stem cells.J Cell Biochem. 94(4): 645-655.

JOYCE N, ANNET G, WIRTHLIN L, OLSON S, BAUER G \& NOLTA JA (2010) Mesenchymal stem cells for the treatment of neurodegenerative disease. Regen Med 5(6): 933-946.

KABAN LB \& GLOWACKI J (1981), Induced osteogenesis in the repair of experimental mandibular defects in rats. J Dent Res 60(7): 1356-1364.

KABAN LB, GLOWACKI J \& MURRAY JE (1979) Repair of experimental mandibular bony defects in rats. Surg Forum 30: 519-521.

KANCZLER J, \& OREFFO ROC (2008) Osteogenesis and angiogenesis: The potential for engineering bone. European Cells and Materials 15: 100-114.

KAVEH K, IBRAHIM R, ABU BAKAR MZ \& IBRAHIM TA (2010) Bone grafting and Bone graft Substitutes. J Anim Vet Adv 9(6): 1055-1067.

KAWAMURA K, YAJIMA H, OHGUSHI H, TOMITA Y, KOBATA Y, SHIGEMATSU K \& TAKAMURA Y (2006) Experimental Study of Vascularized Tissue-Engineered Bone Grafts. Plast. Reconstr Surg 117: 1471-1479.

KIM HJ, PARK SS, OH SY, KIM H, KWEON OK, WOO HM \& KIM WH (2012) Effect of acellular dermal matrix as a delivery carrier of adipose-derived mesenchymal stem cells on bone regeneration. J Biomed Mater Res B Appl Biomater 100(6):1645-1653.

KIM J, SHAPIRO L \& FLYNN A (2015) The clinical application of mesenchymal stem cells and cardiac stem cells as a therapy for cardiovascular disease. Pharmacol Ther. 15: 47-49.

KOCAOEMER A, KERN S, KLÜTER H \& BIEBACK K (2007) Human AB serum and thrombin-activated platelet-rich plasma are suitable alternatives to fetal calf serum for the expansion of mesenchymal stem cells from adipose tissue. Stem Cells 25: 12701278.

KON E, FILARDO G, PERDISA F, VENIERI G \& MARCACCI M (2014). Clinical results of multilayered biomaterials for osteochondral regeneration. Journal of Experimental Orthopaedics 1:1-8. 
KOŹLIK M \& WÓJCICKI P (2014) The use of stem cells in plastic and reconstructive surgery. Adv Clin Exp Med 23(6):1011-1017.

LEUKERS B, ULKAN HG, IRSEN SH, MILZ S, TILLE C, SCHIEKER M \& SEITZ H (2005) Hydroxyapatite scaffolds for bone tissue engineering made by $3 \mathrm{D}$ printing. Journalof materials Science: Materials in Medicine 1(6):1121-1124.

LAZCANO-PONCE E, SALAZAR-MARTÍNEZ E, GUTIÉRREZ-CASTRELLÓN P, ANGELES-LLERENAS A, HERNÁNDEZ-GARDUÑO A \& VIRAMONTES JL (2004) Ensayos clínicos aleatorizados: variantes, métodos de aleatorización, análisis, consideraciones éticas y regulación. Salud Pública de México 46(6): 559-583.

Ley 29/2006 de 26 de junio, de garantías y uso racional de medicamentos y productos sanitarios.

LI HAIYAN, FRIEND JR \& YEO LY (2007) A scaffold cell seeding method driving by Surface acoustic waves. Biomaterials 28: 4098-4109

LIND M, DELEURAN B, THESTRUP-PEDERSEN K, SOBALLE K, ERIKSEN EF \& BÜNGER C (1995) Chemotaxis of human osteoblasts. Effects of osteotropic growth factors. APMIS.103(2):140-146.

LINERO IM, DONCEL A \& CHAPARRO O (2014) Proliferation and osteogenic differentiation of mesenchymal stem cells in hydrogels of human blood plasma. Biomédica 34: 67-78.

LINOSSIER AC, VALENZUELA CY, SOLER ER \& CONTRERAS EM (2011) Colonization of the oral cavity by group mutans streptococci according to age assesed by a semi-quantitative method in saliva. Rev Chil Infect 28 (3): 230-237.

LOHBERGER B, PAYER M, RINNER B, BARTMANN C, STADELMEYER E, TRAUNWISER E, DEVANEY T, JAKSE N, LEITHNER A \& WINDHAGER R (2012) Human Intraoral Harvested Mesenchymal Stem Cells. Characterization, Multilineage. Differentation Analysis, and 3-Dimensional Migration of Natural Bone Mineral and Triclacium Phosphated Scaffolds. Americam Association of Oral and Maxilofacial Surgeons. 2309-2315.

LÓPEZ-DIAZGUERRERO NE, MARTINEZ GARDUÑO CM \& KONIGSBERG FAINSTEIN N (2005) La senescencia replicativa como una respuesta celular al estrés. REB 24 (2): 47-53.

LUCENA S, AROCHA PIÑANGO CL \& GUERRERO B (2007) Fibronectin. Structure and functions associated to hemostasis. Review. Invest Clin 48(2): 249-262.

LUGO-MARTÍNEZ JC (2010). Distraction Osteogenesis: An alternative for the reconstruction of alveolar ridges. When and why. Revista ADM 68(6): 263-267.

MACHADO CV, TELLES PD \& NASCIMENTO IL (2013) Immunological characteristics of mesenchymal stem cells. Rev Bras Hematol Hemoter 35(1): 62-67.

MAFI R, HINDOCHA S, MAFI P, GRIFFIN M \& KHAN WS (2011) Sources of Adult Mesenchymal Stem Cells Applicable for Musculoskeletal Application-A Systematic Review of the Literature. The Open Orthopaedies Journal 2: 242-248. 
MAGALLANES FM, CARMONA RB \& ÁlVAREZ P MA (2010) Aislamiento y caracterización parcial de células madre de pulpa dental. Rev Odont Mexicana 14(1):15-20.

MAIORANA C, BERETTA M, GROSSI GB, SANTORO F, HERFORD AS, NAGURSKY H \& CICCIU M (2011) Histomorphonetric Evaluation of Anorganic Bovine Bone Coverage to Reduce Autogenous Grafts Resorption: Preliminary Results. The Open Dent J. 5: 71-78.

MARK P, KLEINSORGE M, GAEBEL R, LUX CA, TOELK A, PITTERMANN E, DAVID R, STEINHOFF G \& MA N. (2013) Human Mesenchymal Stem Cells Display Reduced Expression of CD105 after Culture in Serum-Free Medium. Stem Cells International 2013: 1-8.

MARTÍN L, ALONSO M, GIROTTI A, ARIAS FJ \& RODRÍGUEZ-CABELLO JC (2009) Synthesis and characterization of macroporous thermosensitive hydrogels from recombinant elastin-like polymers. Biomacromolecules 10(11): 3015-3022.

MARTÍNEZ-VALENCIA AB \& ESPARZA-PONCE HE (2008) Caracterización estructural y morfológica de hidroxiapatita nanoestructurada: estudio comparativo de diferentes métodos de síntesis. Superficies y Vacío 21(4) 18-21.

MARTÍNEZ-VÁZQUEZ FJ, CABAÑAS MV, PARIS JL, LOZANO D \& VALLET-REGÍ M (2015) Fabrication of novel Si-doped hydroxyapatite/gelatine scaffolds by rapid prototyping for drug delivery and bone regeneration. Acta Biomaterialia 15: 200-209.

MARUCCI L, PEDONE E, DI VICINO U, SANUY-ESCRIBANO B, ISALAN M \& PIA COSMA M (2014) $\beta$-Catenin Fluctuates in Mouse ESCs and Is Essential for NanogMediated reprogramming of Somatic Cells to Pluripotency Cell Reports 8: 1686-1696.

MEANA A, GARCÍA E, GARCÍA V, JORCANO JL, DEL RÍO M, LARCHER F, DUARTE B \& HOLGUIN A (2008) Method for preparing three-dimensional structures for tissue engineering. WO 2008/119855.

MELCHES FPW, BARRADAS AMC, VAN BLITTERSWIJK CA, DE BOER J, FEIJEN J \& GRIJPMA DW (2010) Effects of the architecture of tissue engineering scaffolds on cell seeding and culturing. Acta Biomaterialia 6: 4208-4217.

MENDICINO M, BAILEY AM, WONNACOTT K, PURI RK \& BAUER SR (2014). MSCBased Product Characterization for Clinical Trials: An FDA Perspective. Cell Stem Cell 6: $141-145$.

MESEGUER OLMO AL, BERNABEU ESCLAPEZ M, CLAVEL-SAINZ NOLLA M, MUÑOZ RUIZ-SEIQUER J \& RUANO GARCÍA L (1994) Isolation and characterization of osteoblastic cells: Its value in orthopaedic research. Rev Esp Cir Osteoart 29: 235240.

Mesenchymal Stem Cells, Advances and Applications. Bioinformant, 2010

MEYER U, WIESMANN HP, BERR K, KÜBLER NR \& HANDSCHEL J (2006) Cellbased bone reconstruction therapies-principles of clinical approaches. Int $\mathrm{J}$ Oral Maxillofac Implants. 21(6): 899-906. 
MILLER JD \& SCHLAEGER TM (2011). Generation of induced pluripotent stem cell lines from human fibroblasts via retroviral gene transfer. Methods Mol Biol. 767:55-65.

MIYAMOTO K, HAYASHI K, SUZUKI T, ICHIHARA S, YAMADA T, KANO Y, YAMABE T \& ITO Y (2004) Human Placenta Feeder Layers Support Undifferentiated Growth of Primate Embryonic Stem Cells. Stem cells 22:433-440.

MOHAMADREZA BAGHABAN ESLAMINEJAD \& FAEZEH FAGHIHI (2011). Mesenchymal Stem Cell-Based Bone Engineering for Bone Regeneration, Regenerative Medicine and Tissue Engineering-Cells and Biomaterials. Prof. Daniel Eberli (ed)

MONTESPAN F, DESCHASEAUX F, SENSÉBÉ L, CAROSELLA ED \& ROUASFREISS N (2014) Osteodifferentiated Mesenchymal Stem Cells from Bone Marrow and Adipose Tissue Express HLA-G and Display Immunomodulatory Properties in HLAMismatched Settings: Implications in Bone Repair Therapy. Journal of Immunology Research 2014: 1-10

NANDI SK, ROY S, MUKHERJEE P, KUNDU B, DE DK \& BASU D (2010) Orthopaedic applications of bone graft \& graft substitutes: a review. Indian J Med Res 132:15-30.

NAVARRO-VILA C, OCHANDIANO S, LÓPEZ DE ATALAYA FJ, CUESTA M, ACERO J, BARRIOS JM, SALMERÓN JI \& VERDAGUER JJ (2002) Mandibular reconstruction: pedicled and microsurgical flaps. Cir Esp 72(5):287-296.

NICHOLS J, EVANS EP \& SMITH AG (1990) Establishment of germ-line-competent embryonic stem (ES) cells using differentiation inhibing activity. Development 110: 1341-1348.

NIEPONICE A, MAUL TM, CUMER JM, SOLETTI L \& VORP DA (2006) Mechanical stimulation induces morphological and phenotypic changes in bone marrow-derived progenitor cells within a three-dimensional fibrin matrix. $J$ Biomed Mater Res $A$. 81(3):523-30.

NIEPONICE A, SOLETTI L, GUAN J, DESAY BM, HUARD J, WAGNER WR \& VORP DA (2008) Development of a tissue-engineered vascular graft combining a biodegradable scaffold, muscle-derived stem cells and a rotational vacuum seeding technique. Biomaterials 29: 825-833.

NISHIMURA M, TAKASE K, SUEHIRO F \& MURATA H (2012) Candidates Cell Sources to Regenerate Alveolar Bone from Oral Tissue. International Journal of Dentistry 2012: 1-5.

NORMAS DE BUENA PRÁCTICA CLÍNICA (CPMP/ICH/135/95). http://www.aemps.gob.es/industria/inspeccionBPC/docs/guia-BPC octubre-2008.pdf .

O'BRIEN FJ, HARLEY BA, YANNAS IV \& GIBSON LJ (2004) Influence of freezing rate on pore structure in freeze-dried collagen-GAG scaffolds. Biomaterials 25(6): 1077-1086. 
O'BRIEN FJ, HARLEY BA, YANNAS IV \& GIBSON LJ (2005). The effect of pore size on cell adhesion in collagen-GAG scaffolds. Biomaterials 26: 433-441.

OEST ME, DUPONT KM, KONG HJ, MOONEY DJ \& GULDBERG RE (2007) Quantitative Assessment of Scaffold and Growth Factor-Mediated Repair of Critically Sized Bone Defects. J Orthop Res 25: 941-950

OLSON AL \& MCNIECE IK (2015) Novel clinical uses for cord blood derived mesenchymal stromal cells. Cytotherapy 15: 696-699.

OROZCO L, MUNAR A, SOLER R, ALBERCA M, SOLER F, HUGUET M, SENTÍS J, SÁNCHEZ A \& GARCÍA-SANCHO J (2014). Treatment of knee osteoarthritis with autologous mesenchymal stem cells: two-year follow-up results.Transplantation $97(11)$ : 66-68.

OROZCO L, SOLER R, MORERA C, ALBERCA M, SÁNCHEZ A, GARCÍA-SANCHO J. (2011) Intervertebral disc repair by autologous mesenchymal bone marrow cells: a pilot study. Transplantation. 92: 822-828.

OROZCO L, MUNAR A, SOLER R, ALBERCA M, SOLER F, HUGUET M, SENTÍS J, SÁNCHEZ A, GARCÍA-SANCHO J. (2013) Treatment of knee osteoarthritis with autologous mesenchymalstem cells: a pilot study. Transplantation. 95:1535-1541.

PANSERI S, RUSSO A, CUNHA C, BONDI A, DI MARTINO A, PATELLA S \& KON E (2011). Osteochondral tissue engineering approaches for articular cartilage and subchondral bone regeneration. Knee Surg Sports Traumatol Arthrosc, 20(6):11821191.

PARIS JL, ROMÁN J, MANZANO M, CABAÑAS MV AND VALLET REGÍ M (2015) Tuning dual-drug reléase from composite scaffolds for bone regeneration. International Journal of Pharmaceutics 486: 30-37.

PATEL SA, SHERMAN L, MUNOZ J \& RAMESHWAR P (2008) Immunological properties of mesenchymal stem cells and clinical implications. Arch Immunol Ther Exp (Warsz). 56(1):1-8.

PARK Y, LEE SJ, CHOI IY, LEE SR, SUNG HJ, KIM JH, YOO YD, GEUM DH, KIM SH \& KIM BS (2010) The efficacy of human placenta as a source of the universal feeder in human and mouse pluripotent stem cell culture. Cell Reprogram 12(3): 315328.

PARK HJ, SHIN JY, KIM HN, OH SH \& LEE PH (2014) Neuroprotective effects of mesenchymal stem cells through autophagy modulation in a parkinsonian model. Neurobiol Aging 35(8): 1920-1928.

PETERSON B, ZHANG J, IGLESIAS R, KABO M, HEDRICK M, BENHAIM P \&. LIEBERMAN JR (2005). Healing of Critically Sized Femoral Defects, Using Genetically Modified Mesenchymal Stem Cells from Human Adipose Tissue. Tissue Engineering 11 (1/2): 120-129.

PETITE H, VIATEAU V, BENSAIID W, MEUNIER A, DE POLLAK C, BOURGUIGNON M, OUDINA K, SEDEL L \& GUILLEMIN G (2000) Tissue-engineered bone regeneration. Nature Biotechnology 18: 959-963. 
PERAL CAGIGAL B, REDONDO GONZÁLEZ LM, VERRIER HERNÁNDEZ A, SERRAT SOTO A, TORRES NIETO MA \& VAQUERO PUERTA C (2008) Experimental study in rats of mandibular bone regeneration with different biomaterials. Rev Esp Cir Oral y Maxilofac 30(5): 313-323.

PILZ GA, BRAUN J, ULRICH C, FELKA T, WARSTAT K, RUH M, SCHEWE B, ABELE H, LARBI A \& AICHER WK (2011) Human Mesenchymal Stromal Cells Express CD14 Cross-Reactive Epitopes. Cytometry Part A 79(8):635-645.

PINEDA C \& LONDOÑO C (2009) Adipose tissue derived mesenchymal stem cells, isolation and differentiation into the osteogenic lineage. Revista Ingeniería Biomédica 3(5): 58-65.

PITTENGER MF, MACKAY AM, BECK SC, JAISWAL RK, DOUGLAS R, MOSCA JD, MOORMAN MA, SIMONETTI DW, CRAIG S \& MARSHAK DR (1999) Multilineage potential of adult human mesenchymal stem cells. Science.284(5411):143-147.

PLAZAS BONILLA CE \& PERILLA JE (2011) The past, present and near future of materials for use in biodegradable orthopaedic implants. Ingeniería e Investigación 31 (2): 124-133.

PULIDO F, GARRIDO J \& GARZÓN I (2013). BMP-2 in Traumatology. Advances in Tissue Engineering. Actual Med 98(790): 154-159.

RÁBAGO TORRE LR, QUINTANILLA LÁZARO EM \& MORÁN ORTIZ DE SOLÓZANO M (2009) Aplicaciones de los pegamentos biológicos en endoscopia digestiva. GH Continuada 8(1): 32-36.

Real Decreto 561/1993, de16 de abril, por el que se establecen los requisitos para la realizacion de ensayos clinicos con medicamentos

Real Decreto 223/2004, de 6 de febrero, por el que se regulan los ensayos clínicos con medicamentos.

Reglamento (CE) no 1394/2007 del Parlamento Europeo y del Consejo del 13 de noviembre de 2007

REYNOLDS MA, AICHELMANN-REIDY ME \& BRANCH-MAYS GL (2010) Regeneration of periodontal tissue: bone replacement grafts. Dent Clin North Am. 54(1): 55-71.

REZWAN K, CHEN QZ, BLAKER JJ \& BOCCACCINI AR (2006) Biodegradable and bioactive porous polymer/inorganic composite scaffolds for bone tissue engineering. Biomaterial 27: 3413-3431.

ROBEY PG (1995). Collagenase-treated trabecular bone fragment: a reproducible source of cells in the osteoblastic lineage .Calcif Tissue Int.56:S11-S12.

RODRÍGUEZ FLORESJ, PALOMAR GALLEGO MA \& GARCÍA-DENCHE JT (2012) Platelet-rich plasma: biology and applications in maxillofacial surgery and facial aesthetics Rev Esp Cir Oral Maxilofac . 34(1): 8-17. 
ROSSIGNOLI F, CASELLI A, GRISENDI G, PICCINNO S, BURNS JS, MURGIA A, VERONESI E, LOSCHI P, MASINI C, CONTE P, PAOLUCCI P, HORWITZ EM \& DOMINICI M (2013) Isolation, Characterization, and Transduction of Endometrial Decidual Tissue Multipotent Mesenchymal Stromal/Stem Cells from Menstrual Blood. Bio Med Res Int 2013: 1-14.

SABAPATHY V, RAVI S, SRIVASTAVA V, SRIVASTAVA A \& KUMAR S (2012) Long-Term Cultured Human Term Placenta Derived Mesenchymal Stem Cells of Maternal Origin Displays Plasticity. Stem Cells International 2012: 1-11

SACRISTÁN JA, SOTO J \& GALENDE I (1993) Evaluación crítica de ensayos clínicos. Med Clin (Barc) 100: 780-787.

SALEM HK \& THIEMERMANN C (2010) Mesenchymal Stromal Cells: Current Understanding and Clinical Status. Stem Cell 28: 585-596.

SALGADO AJ, COUTINHO OP \& REIX RL (2004). Bone Tissue Engineering: State of the Art and Future Trends. Macromol.Biosci 4: 743-765.

SCHÖNMEYR B, CLAVIN N, AVRAHAM T, LONGO V \& MEHRARA BJ (2009) Synthesis of a tissue-engineered periosteum with acellular dermal matrix and cultured mesenchymal stem cells. Tissue Eng Part A 15(7): 1833-1841.

SELL S, GAISSMAIER C, FRITZ J, HERR G, ESENWEIN S, KÜSSWETTER W, VOLKMANN R, WITTKOWSKI KM \& RODEMANN HP (1997). Different Behavior of Human Osteoblast-Like Cells Isolated from Normal and Heterotopic Bone In Vitro. Calcif Tissue Int 62: 51-59.

SHAMBLOTT MJ, AXELMAN J, WANG S, BUGG EM, LITTLEFIELD JW, DONOVAN PJ, BLUMENTHAL PD, HUGGINS GR \& GEARHART JD (1998) Derivation of pluripotent stem cells from cultured human primordial germ cells. Natl. Acad. Sci. USA 95: 13726-13731.

SHI M, LIU ZW \& WANG FS (2011) Immunomodulatory properties and therapeutic application of mesenchymal stem cells. Clinical and Experimental Immunology 164: 18.

SMITH AG, HEATH JK, DONALDSON DD, WONG GG, MOREAU J, STAHI M \& ROGERS D (1988). Inhibition of pluripotential embryonic stem cell differentiation by purified polypeptides. Nature 336 (6200): 688-690.

SOBRAL JM, CARIDADE SG, SOUSA RA, MANO JF \& REIS RL (2011) Threedimensional plotted scaffolds with controlled pore size gradients: Effect of scaffold geometry on mechanical performance and cell seeding efficiency. Acta Biomaterialia 7:1009-1018.

SOTIROPOULOU PA \& PAPAMICHAIL M (2007) Immune properties of mesenchymal stem cells. Methods Mol Biol 407; 225-243

SONG YG \& CHO IH (2014) Characteristics and osteogenic effect of zirconia porous

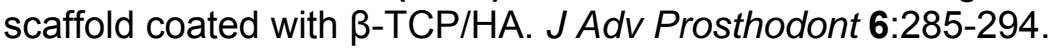

STUTE N, HOLTZ K, BUBENHEIM M, LANGE C, BLAKE F \& ZANDER AR (2004) Autologous serum for isolation and expansion of human mesenchymal stem cells for clinical use. Exp Hematol 32(12):1212-1225. 
SUÁREZ-GONZÁLEZ D, LEE JS, DIGGS A, LU Y, NEMKE B, MARKEL M, HOLLISTER SJ \& MURPHY WL (2014) CONTROLLED multiple growth factor delivery from bone tissue engineering scaffolds via designed affinity. Tissue Eng Part A. 20(1516): 2077-2087.

SULAIMAN SB, KEONG IK, CHENG CH, BIN SAIM A \& BT. HJIDRUS R (2013) Tricalcium phosphate/hydroxyapatite (TCP-HA) bone scaffold as potential candidate for the formation of tissue engineered bone. Indian J Med Res 137: 1093-1101.

TAKAHASHI K \& YAMANAKA S (2006) Induction of Pluripotent Stem Cells from Mouse Embryonic and Adult Fibroblast Cultures by Defined Factors. Cell 126: 663676.

TAKAHASHI K, TANABE K, OHNUKI M, NARITA M, ICHISAKA T, TOMODA K \& YAMANAKA $S$ (2007) Induction of Pluripotent Stem Cells from Adult Human Fibroblasts by Defined Factors. Cell 131: 861-872.

TANODEKAEW S, CHANNASANON S, KAEWKONG P \& UPPANAN P (2013). PLAHA scaffolds: preparation and bioactivity Procedia Engineering 59; 144-149.

TAYAPONGSAK P, O'BRIEN DA \& MONTEIRO CB (1994) Autologous fibrin adhesive in mandibular reconstruction with particulate cancellous bone and marrow. $J$ Oral Maxillofac Surg 52: 161-166.

TESTERA AM, GIROTTI A, DE TORRE IG, QUINTANILLA L, SANTOS M, ALONSO M, RODRÍGUEZ-CABELLO JC (2015). Biocompatible elastin-like click gels: design, synthesis and characterization. J Mater Sci Mater Med.26(2):105

THOMSON JA, ITSKOVITZ-ELDOR J, SHAPIRO SS, WAKNITZ MA, SWIERGIEL JJ, MARSHALL VS \& JONES JM (1998) Embryonic stem cell lines derived from human blastocyst. Science, 282 (5391): 1145-1147.

THORWARTH M, SCHLEGEL KA, WEHRHAN F, SROUR S \& SCHULTZE-MOSGAU $S$ (2006) Acceleration of de novo bone formation following application of autogenous bone to particulatedanorganic bovine material in vivo. Oral Surg Oral Med Oral Pathol Oral Radiol Endod 101 (3): 309-316.

TOKCAER-KESKIN Z, RUCHAN AA, AYALOGLU-BUTUN F, TERZIOGLU-KARA E, SERKAN D , OZYURDA U, UGUR M \& AKCALI KC (2009). Timing of induction of cardiomyocyte differentiation for in vitro cultured mesenchymal stem cells: a perspective for emergencies. Canadian journal of physiology and pharmacology 87(2): 143-150.

TORTOLINI P \& RUBIO S (2012) Different alternatives of bone grafts. Av Periodon Implantol 24, 3: 133-138

TRAN HLE B, DOAN VN, LE HT \& NGO LT (2014). Various methods for isolation of multipotent human periodontal ligament cells for regenerative medicine. In Vitro Cell Dev Biol Anim 50 (7): 597-602.

TRAN RT, NASERI E, KOLASNIKOV A, BAI X \& YANG J (2011) A new generation of sodium chloride porogen for tissue engineering. Int Union of Bioch and Mol Biology $\mathbf{5 8}$ (5): $335-344$. 
TRUJILLO-ROLDAN MA \& VALDEZ-CRUZ NA (2009) The use of disponsable bioreactors in the biopharmaceutical industry and its implications on engineering. Dyna 76(158): $275-283$

UCCELLI A, MORETTA L \& PISTOIA V (2006). Imnunoregulatory function of mesenchymal stem cells. Eur J Immunol. 36(10): 2566-2573.

UNGER C, FELLDIN U, NORDENSKJÖLD A, DILBER MS \& HOVATTA O (2008). Derivation of human skin fibroblast lines for feeder cells of human embryonic stem cells. Curr Protoc Stem Cell Biol 1.

UNGER C, GAO S, COHEN M, JACONI M, BERGSTROM R, HOLM F, GALAN A, SANCHEZ E, IRION O, DUBUISSON JB, GIRY-LATERRIERE M, SALMON P, SIMON C, HOVATTA O \& FEKI A (2009). Immortalized human skin fibroblast feeder cells support growth and maintenance of both human embryonic and induced pluripotent stem cells. Human Reproduction 24 (10): 2567-2581.

VALLIER L, MENDJAN S, BROWN S, CHNG Z, TEO A, SMITHERS LE, TROTTER MW, CHO CH, MARTINEZ A, RUGG-GUNN P, BRONS G \& PEDERSEN RA (2009) Activin/Nodal signalling maintains pluripotency by controlling Nanog expression. Development 136(8): 1339-49.

VALLIER L, TOUBOUL T, CHNG Z, BRIMPARI M, HANNAN N, MILLAN E, SMITHERS LE, TROTTER M, RUGG-GUNN P, WEBER A \& PEDERSEN RA (2009) Early Cell Fate Decisions of Human Embryonic Stem Cells and Mouse Epiblast Stem Cells Are Controlled by the Same Signalling Pathways. Plos ONE 4 (6): 1-13.

VEGA A, MARTÍN-FERRERO MA, DEL CANTO F, ALBERCA M, GARCÍA V, MUNAR A, OROZCO L, SOLER R, FUERTES JJ, HUGUET M, SÁNCHEZ A \& GARCÍA-SANCHO J (2015).Treatment of Knee Osteoarthritis with Allogeneic Bone Marrow Mesenchymal Stem Cells: A Randomized Controlled Trial. TransplantationIn press

VELASCO PEÑA MA \& GARZÓN ALVARADO DA (2010) Scaffolds implants for the bone regeneration. Materials, techniques and modeling by means of reaction-diffusion systems. Revista Cubana de Investigaciones Biomèdicas 29(1): 140-154.

VILA MORALES D, GARMENDIA HERNÁNDEZ G \& GARMENDIA AMF (2011). Osteogenesis by distraction in mandibular defects and skeletal stability after two years of treatment. Revista Cubana de Estomatología 48(1): 29-42.

VISWANATHAN S, KEATING A, DEANS R, HEMATTI P, PROCKOP D, STRONCEK DF, STACEY G, WEISS DJ, MASON C \& RAO MS (2014) Soliciting Strategies for Developing Cell-Based Reference Materials to Advance Mesenchymal Stromal Cell Research and Clinical Translation. Stem Cells Dev 23(11): 1157-1167.

WAGNER W, WEIN $F$, SECKINGER A, FRANKHAUSER $M$, WIRKE $U$, KRAUSE U, BLAKE J, SCHWAGER C, ECKSTEIN V, ANSORGE W \& HO AD (2005) Comparative characteristics of mesencymal stem cells from human bone marrow, adipose tissue, and umbilical cord blood. Experimental Hematology 33: 1402-1416. 
WANG M (2006) Composite Scaffolds for Bone Tissue Engineering. Am. J. Biochem \& Biotech 2(2): 80-84.

WUCHTER P, BIEBACK K, SCHREZENMEIER H, BORNHÄUSER M, MÜLLER LP, BÖNIG $H$, WAGNER W, MEISEL R, PAVEL $P$, TONN T, LANG P, MÜLLER I, RENNER M, MALCHEREK G, SAFFRICH R, BUSS EC, HORN P, ROJEWSKI M, SCHMITT A, HO AD, SANZENBACHER R, SCHMITT M (2015). Standardization of Good Manufacturing Practice-compliant production of bone marrow-derived human mesenchymal stromal cells for immunotherapeutic applications. Cytotherapy. 17(2): 128-139.

YANG S, LEONG K-F, MSE, MSME, DU Z \& CHUA C-K (2001) The Design of Scaffolds for Use in Tissue Engineering.Part I. Traditional Factors. Tissue Engineering 7(6): 679-689.

YOUNGER EM \& CHAPMAN MW (1989) Morbidity at bone graft donor sites. Journal of Orthopaedic Trauma 3(3): 192-195.

YU J, VODYANIK MA, SMUGA-OTTO K, ANTOSIEWICZ-BOURGET J, FRANE JL, TIAN S, JONSDOTTIR GA, RUOTTI V, STEWART R, SLUKVIN II \& THOMSON JS (2007). Induced pluripotent stem cell lines derived from human somatic cells. Science 318: 1917-1920.

ZAIDI N \& NIXON AJ (2007) Stem Cell Therapy in Bone Repair and Regeneration. Ann. N.Y.Acad. Sci. 1117: 62-72.

ZCHNDER T, SARKER B, BOCCACCINI AR \& DESTCH R (2015). Evaluation of an alginate-gelatine crosslinked hydrogel for bioplotting. Biofabrication 7: 1-12.

ZELTINGER J, SHERWOOD JK, GRAHAM DA, MÜELLER R \& GRIFFITH LG (2001) Effect of poro size and void fraction on cellular adhesion, proliferation and matrix deposition. Tissue Eng 7(5): 557-572.

ZHU S-J, CHOI B-H, JUNG J-H, LEE S-H, HUH J-Y, YOU T-M, LEE H-J \& LI J. (2006) A comparative histologic analysis of tissue-engineered bone using platelet-rich plasma and platelet-enriched fibrin glue. Oral Surg Oral Med Oral Pathol Oral Radiol Endod 102: 175-179.

ZUK PA, ZHU M, ASHJIAN P, DE UGARTE DA, HUANG JI, MIZUNO H, ALFONSO ZC, FRASER JK, BENHAIM P \& HEDRICK MH (2002) Human Adipose Tissue is a Source of Multipotent Stem Cells. Molecular Biology of the Cell 13: 4279-4295. 
